\title{
Prawo wewnętrzne związków wyznaniowych w perspektywie organów władzy publicznej \\ Klauzule generalne
}



Prawo wewnętrzne związków wyznaniowych w perspektywie organów władzy publicznej

Klauzule generalne

Ks. Piotr KroczeK 
Recenzenci:

dr hab. Paweł Czubik, prof. Uex

ks. dr hab. Piotr Steczkowski, prof. UR

Korekta:

Renata Komurka

Skład, łamanie, przygotowanie okładki:

Pracownia Wydawnicza AD VERBUM

Na okładce: (C) abbiesartshop/fotolia

Książka przedstawia rezultaty badań prowadzonych przez autora w ramach grantu o numerze UMO-20I4/13/B/Hs5/OI482

finansowanego przez NCN

(C) 2017 by Uniwersytet Papieski Jana Pawła II w Krakowie

ISBN 978-83-7438-573-2 (wersja drukowana)

ISBN 978-83-7438-574-9 (wersja online)

DOI: http://dx.doi.org/IO.I5633/9788374385749

Uniwersytet Papieski Jana Pawła II w Krakowie

Wydawnictwo Naukowe

30-348 Kraków, ul. Bobrzyńskiego Io

tel./faks: 124226040

e-mail: wydawnictwo@upjpz.edu.pl 


\section{Wykaz skrótów}

\section{Źródła prawa}

CIC - Codex Iuris Canonici. Pii x Pontificis Maximi iussu digestus, Benedicti

Papae $X V$ auctoritate promulgatus, $1917 \mathrm{r}$.

k.c. - Ustawa z dnia 23 kwietnia 1964 r. Kodeks cywilny

k.k. - Ustawa z dnia 6 czerwca 1997 r. Kodeks karny

k.k.w. - Ustawa z dnia 6 czerwca 1997 r. Kodeks karny wykonawczy

k.p.c. - Ustawa z dnia I7 listopada I964 r. Kodeks postępowania cywilnego

KKK - Katechizm Kościota Katolickiego, 1992 r.

KKKW - Codex Canonum Ecclesiarum Orientalium auctoritate Ioannis

Pauli PP. II promulgatus; Kodeks kanonów Kościotów wschodnich, $1990 \mathrm{r}$.

Konkordat - Konkordat między Stolicą Apostolską i Rzecząpospolitą Polską z 1993 r.

Konstytucja RP - Konstytucja Rzeczypospolitej Polskiej z dnia 2 kwietnia 1997 r. KPK - Codex Iuris Canonici auctoritate Ioannis Pauli PP. II promulgatus; Kodeks

prawa kanonicznego, $1983 \mathrm{r}$.

LG - Sacrosanctum Concilium Oecumenicum Vaticanum II, Constitutio dogmatica Lumen gentium de Ecclesia, $1964 \mathrm{r}$.

PSKE-A - Pragmatyka Służbowa Kościoła Ewangelicko-Augsburskiego w Rzecz-

pospolitej Polskiejz dnia 28 listopada 1999 r.

PWKE-M - Prawo Wewnętrzne Kościoła Ewangelicko-Metodystycznego w Rze-

czypospolitej Polskiej z dnia 25 maja I99i r.

PWKE-R - Prawo Wewnętrzne Kościoła Ewangelicko-Reformowanego w Rze-

czypospolitej Polskiej (weszło w życie I stycznia 20I5 r.).

PWKP - Prawo Wewnętrzne Kościoła Polskokatolickiego w Rzeczypospolitej

Polskiej z dnia 27 czerwca $1995 \mathrm{r}$.

PWKZ - Prawo Wewnętrzne Kościoła Zielonoświątkowego w Rzeczypospolitej

Polskiej z dnia 28 września $2007 \mathrm{r}$.

PWwwŻ - Prawo wewnętrzne wyznaniowej wspólnoty żydowskiej w Rzeczy-

pospolitej Polskiej z dnia I5 stycznia 2006 r. 
r.s.p.w.k.s. - Rozporządzenie Prezydenta Rzeczypospolitej z dnia 22 marca 1928 r. o stosunku Państwa do Wschodniego Kościoła Staroobrzędowego, nie posiadającego hierarchji ${ }^{1}$ duchownej

SKADS - Statut Kościoła Adwentystów Dnia Siódmego w Rzeczypospolitej Polskiej z dnia I2 czerwca $2008 \mathrm{r}$.

SKKM - Statut Kościoła Katolickiego Mariawitów w Rzeczypospolitej Polskiej $\mathrm{z}$ dnia I4 maja I968 $\mathrm{r}$.

SKSM - Statut Kościoła Starokatolickiego Mariawitów w Rzeczypospolitej Polskiej z dnia 26 kwietnia $1967 \mathrm{r}$.

SKZR - Statut Karaimskiego Związku Religijnego w Rzeczypospolitej Polskiej $\mathrm{z}$ dnia I8 marca $1973 \mathrm{r}$.

SMZR2009 - Statut Muzułmańskiego Związku Religijnego w Rzeczypospolitej

Polskiej z dnia 28 lutego 2009 r.

SMZRI936 - Statut Muzułmańskiego Związku Religijnego w Rzeczypospolitej

Polskiej z dnia 26 sierpnia $1936 \mathrm{r}$.

sWKs - Statut Wschodniego Kościoła Staroobrzędowego nieposiadającego

hierarchii duchowej z dnia 25 marca $1984 \mathrm{r}$.

swPAKP - Statut Wewnętrzny Polskiego Autokefalicznego Kościoła Prawosławnego $\mathrm{z}$ dnia Io lutego $1995 \mathrm{r}$.

u.g.w.s.w. - Ustawa z dnia I7 maja I989 r. o gwarancjach wolności sumienia i wyznania

u.s.p.g.w.ż. - Ustawa z dnia 20 lutego 1997 r. o stosunku Państwa do gmin wyznaniowych żydowskich w Rzeczypospolitej Polskiej

u.s.p.k.a.d.s. - Ustawa z dnia 30 czerwca 1995 r. o stosunku Państwa do Kościoła Adwentystów Dnia Siódmego w Rzeczypospolitej Polskiej

u.s.p.k.ch.b. - Ustawa z dnia 30 czerwca 1995 r. o stosunku Państwa do Kościoła Chrześcijan Baptystów w Rzeczypospolitej Polskiej

u.s.p.k.e-a. - Ustawa z dnia I3 maja I994 r. o stosunku Państwa do Kościoła Ewangelicko-Augsburskiego w Rzeczypospolitej Polskiej

u.s.p.k.e-m. - Ustawa z dnia 30 czerwca 1995 r. o stosunku Państwa do Kościoła Ewangelicko-Metodystycznego w Rzeczypospolitej Polskiej

u.s.p.k.e-r. - Ustawa z dnia I3 maja I994 r. o stosunku Państwa do Kościoła Ewangelicko-Reformowanego w Rzeczypospolitej Polskiej

u.s.p.k.k. - Ustawa z dnia I7 maja 1989 r. o stosunku Państwa do Kościoła Katolickiego w Rzeczypospolitej Polskiej

I Tu i w innych miejscach zgodnie z pisownią w rozporządzeniu. 
u.s.p.k.k.m. - Ustawa z dnia 20 lutego 1997 r. o stosunku Państwa do Kościoła Katolickiego Mariawitów w Rzeczypospolitej Polskiej

u.s.p.k.p. - Ustawa z dnia z dnia 30 czerwca 1995 o stosunku Państwa do Kościoła Polskokatolickiego w Rzeczypospolitej Polskiej

u.s.p.k.s.m. - Ustawa z dnia 20 lutego 1997 r. o stosunku Państwa do Kościoła Starokatolickiego Mariawitów w Rzeczypospolitej Polskiej

u.s.p.k.z. - Ustawa z dnia 20 lutego 1997 r. o stosunku Państwa do Kościoła Zielonoświątkowego w Rzeczypospolitej Polskiej

u.s.p.k.z.r. - Ustawa z dnia 2I kwietnia 1936 r. o stosunku Państwa do Karaimskiego Związku Religijnego w Rzeczypospolitej Polskiej

u.s.p.m.z.r. - Ustawa z dnia 2I kwietnia 1936 r. o stosunku Państwa do Muzułmańskiego Związku Religijnego w Rzeczypospolitej Polskiej

u.s.p.p.a.k.p. - Ustawa z dnia 4 lipca I99I r. o stosunku Państwa do Polskiego Autokefalicznego Kościoła Prawosławnego

ZPWKE-A - Zasadnicze Prawo Wewnętrzne Kościoła Ewangelicko-Augsburskiego w Rzeczpospolitej Polskiej z dnia 26 października $1996 \mathrm{r}$.

ZPWкCв - Zasadnicze Prawo Wewnętrzne Kościoła Chrześcijan Baptystów w Rzeczypospolitej Polskiej z dnia I października 2005 r.

\section{Inne skróty}

AAS - „Acta Apostolicae Sedis”

C. - caput

can. - canon

Cz. - częś́́

D. - distinctio

dz. cyt. - dzieło cytowane

Dz.U. - „Dziennik Ustaw Rzeczypospolitej Polskiej”

Dz.Urz. UE. - „Dziennik Urzędowy Unii Europejskiej”

kan. - kanon

kol. - kolumna

M.P. - „Monitor Polski. Dziennik Urzędowy Rzeczypospolitej Polskiej”

przyp. - przypis

s. - strona

tekst jedn. - tekst jednolity

vol. - volumen

z. - zeszyt 
Skróty ksiąg Pisma Świętego według Pismo Święte Starego i Nowego Testamentu w przekładzie z języków oryginalnych, opracował zespół biblistów polskich z inicjatywy benedyktynów tynieckich, Poznań-Warszawa 1983, s. I3. 


\section{Wstęp}

Powszechnie uznaje się, że wykładnia prawa jest bardzo trudnym zadaniem. Natomiast dokonywanie interpretacji ustawy pochodzenia egzogenicznego, czyli należącej do „obcego prawa”, jest pracą niezwykle niebezpieczną, bowiem obarczoną poważnym ryzykiem błędu. Sprawa jest jeszcze bardziej skomplikowana, gdy przedstawiciel doktryny prawa polskiego musi się zawodowo zmierzyć z wewnętrznym prawem danego kościoła lub innego związku wyznaniowego. Ma to miejsce na przykład w sytuacji, gdy przepisy prawa własnego, czyli polskiego, odsyłają do tego prawa.

Głównym celem niniejszej książki jest przedstawienie propozycji modelowego postępowania organów polskiej władzy publicznej z prawem wewnętrznym kościołów lub innych związków wyznaniowych ${ }^{\mathrm{I}} \mathrm{o}$ uregulowanym przez ustawy stosunku do Rzeczypospolitej Polskiej. W tym postępowaniu szczególna uwaga zostanie zwrócona na klauzule generalne zawarte w ich prawie wewnętrznym. Biorąc pod uwagę pewne wspólne cechy wszystkich zrzeszeń służących zaspokajaniu religijnych potrzeb, wydaje się, że mutatis mutandis można niniejsze rozważania zastosować do prawa wewnętrznego także i innych związków wyznaniowych, czyli tych, które znajdują się poza wspominanym katalogiem.

Celem pobocznym niniejszej pracy jest stworzenie sposobności do poznania prawa wewnętrznego wspomnianych kościołów lub innych związków wyznaniowych. Może to stanowić pewną podstawę do dialogu ekumenicznego czy też dialogu międzyreligijnego pomiędzy nimi.

Niektóre ze wskazówek zawartych w tej książce mogą być przydatne także kanonistom ${ }^{2}$. Chodzi głównie o sędziów kościelnych, którzy muszą wypowiedzieć

I W niniejszej pracy terminy te są stosowane zamiennie z takimi terminami, jak: „zrzeszenie religijne”, „wspólnota religijna”, „grupa religijna”.

2 Za kanonistę uważać należy prawnika zajmującego się prawem Kościoła katolickiego. 
się na temat nieważności małżeństwa ochrzczonych akatolików, posługując się prawem egzogenicznym wobec ich własnego prawa kanonicznego ${ }^{3}$.

Książka ma trzy rozdziały odpowiadające elementom jej tytułu: związki wyznaniowe, ich wewnętrzne prawo i klauzule generalne. W pierwszym rozdziale przedstawiono prawny status kościołów i innych związków wyznaniowych, ze szczególnym zwróceniem uwagi na te, których prawny status jest uregulowany poprzez poświęcone im indywidualne akty normatywne - ustawy i rozporządzenia. Drugi rozdział zawiera opis prawa endogenicznego kościołów $\mathrm{i}$ innych związków wyznaniowych. Zwraca się w nim uwagę na specyfikę tego prawa, szczególnie w zestawieniu z prawem polskim. W tym miejscu należy wyjaśnić, że termin „prawo endogeniczne”, czyli prawo powstałe na gruncie danego związku wyznaniowego, może być w przypadkach podmiotów religijnych, o których mowa w książce, sprowadzone do terminu „prawo wewnętrzne”, czyli prawo obowiązujące w obrębie danego podmiotu ${ }^{4}$. Żadnemu bowiem z kościołów i innych związków wyznaniowych będących przedmiotem analizy nie narzucono całkowicie prawa wewnętrznego, choć takie przypuszczenie można wysnuć w odniesieniu do niektórych przepisów prawa wewnętrznego, szczególnie tych przyznających uprawnienia nadzorcze czy kontrolne państwu. Gdyby jednak sytuacja narzucenia prawa przez państwo związkowi wyznaniowemu miała miejsce, to wówczas nie można by takiego prawa nazwać „prawem endogenicznym”, lecz „prawem wewnętrznym o egzogenicznym pochodzeniu”. Rozdział trzeci obejmuje szczegółową prezentację klauzul generalnych zawartych w prawie endogenicznym kościołów i innych związków wyznaniowych. Jest to kluczowa część publikacji.

W tym miejscu trzeba zasygnalizować potencjalne trudności w odbiorze tej książki. Po pierwsze, prawo wewnętrzne kościołów i innych związków wyznaniowych jest zwykle bardzo silnie powiązane z doktryną religijną danego związku wyznaniowego, także w tym sensie, że doktryna kształtuje treść normatywną tego prawa. $Z$ tego powodu może być ono określone terminem „prawo religijne"s. Po drugie, prawo, o którym mowa, to prawo specyficzne i jego funkcjonowanie we wspólnocie, w której powstało, rządzi się niekiedy innymi prawidłami niż funkcjonowanie prawa państwowego. Po trzecie, rzeczywistość

3 Termin „prawo kanoniczne” (ius canonicum) będzie odnoszony w niniejszej książce do prawa Kościoła katolickiego.

4 Stąd też te terminy będą stosowane zamiennie.

5 Terminy te będą w książce stosowane wymiennie. 
prawa religijnego wymyka się niekiedy ustaleniom polskiej teorii prawa, co może prowadzić do tego, że ,zewnętrzny interpretator” bez powodzenia będzie szukał odniesień lub analogii do znanego sobie systemu prawa. Po czwarte, terminy prawne lub prawnicze i instytucje prawne funkcjonujące w prawie religijnym kościołów lub innych związków wyznaniowych są w wielu wypadkach obce przedstawicielowi doktryny prawa polskiego.

Konieczność zniwelowania wspomnianych trudności poprzez wprowadzenie objaśnień i wstępów koniecznych dla „zewnętrznego interpretatora” jest, jak się wydaje, wystarczającym argumentem, który pozwala odeprzeć ewentualny zarzut, iż dwa pierwsze rozdziały książki są długim wstępem do rozdziału trzeciego obejmującego istotę tematu. Należy mieć nadzieję, że informacje zawarte w tych rozdziałach okażą się interesujące pod względem poznawczym i że książka jako całość dzięki nim zyskała.

Do przeprowadzenia rozważań na temat klauzul generalnych w prawie kościołów i innych związków wyznaniowych pomocne było, a nawet konieczne, posłużenie się osiągnięciami polskiej doktryny prawniczej w zakresie klauzul generalnych. Nie chodziło jednak o przegląd polskiej myśli prawniczej w tym zakresie, ani tym bardziej o jej uporządkowanie ${ }^{6}$. Nie była także celem aprobata tych poglądów ani polemika z nimi. Chodziło raczej o wskazanie w dorobku polskiej jurysprudencji istotnych z punktu widzenia prawa związków wyznaniowych elementów, które pomagają uchwycić fenomen klauzul generalnych w ich wewnętrznym prawie. Do takiego zabiegu ograniczającego głos polskiej doktryny prawniczej upoważnia specyfika wspomnianego prawa, do którego nie można zastosować wszystkich ustaleń polskiej teorii prawa. Takie podejście jest również zgodne z metodologiczną instrukcją Arystotelesa wskazującą, że wystarczy, by opracowanie przedmiotu osiągnęło taki stopień jasności, na jaki ów przedmiot pozwala i jaki jest rzeczywiście potrzebny. Nie we wszystkich wywodach należy bowiem szukać tego samego stopnia ścisłości.

6 Dyskusja dotycząca klauzul generalnych toczy się w Polsce od lat pięćdziesiątych ubiegłego wieku. W artykule Z. Radwański, M. Zieliński, Uwagi „de lege ferenda” o klauzulach generalnych w prawie prywatnym, "Przegląd Legislacyjny” (200I) nr 2, s. II-I6 dokonują uporządkowania poglądów i terminologii w przedmiotowym zakresie.

7 Por. Arystoteles, Etyka nikomachejska, przeł. D. Gromska, Warszawa 1956, księga I, 3. 
Posługiwanie się przez prawodawcę klauzulami generalnymi jest konieczne w każdym systemie prawnym. Zawierają je ustawodawstwa zarówno współczesne, jak i dawne ${ }^{8}$. Także wspominane elementy techniki legislacyjnej znajdują się w prawie kościołów i innych związków wyznaniowych. Słuszne jest twierdzenie, że temat klauzul generalnych skupia w sobie - jak w soczewce - ogrom zagadnień dotyczących m.in. stosunku prawa do moralności, wartości samego prawa oraz jego roli w społeczności ${ }^{9}$. Z punktu widzenia prawa endogenicznego obowiązującego we wspólnotach religijnych problem łączności prawa i moralności czy doktryny jest szczególnie istotny. Zasadniczo bowiem zadania, jakie prawo i inne normy pełnią we wspólnotach, są bardzo zbliżone. Są to zadania o charakterze religijnym.

Porządek moralno-doktrynalny jest wyższorzędny wobec prawa stanowionego. Jednakże sama obecność prawa w tych wspólnotach pokazuje, że normy moralno-doktrynalne nie są wystarczające, aby zapewnić wspólnocie istnienie, funkcjonowanie, rozwój oraz wypełnianie podstawowej funkcji, czyli zaspokajanie potrzeb religijnych. Istnieje potrzeba użycia prawa. Jego źródłem może być jego stanowienie. Oznacza to, że system norm, który to prawo tworzy, musi wspótistnieć i być harmonijnie złączony z systemem moralno-doktrynalnym obowiązującym pierwotnie we wspólnocie.

Narracja w niniejszej pracy została przeprowadzona z punktu widzenia „zewnętrznego interpretatora”, czyli osoby, która w swojej codziennej pracy prawniczej znajduje się poza kręgiem prawa wewnętrznego związków wyznaniowych. Najczęściej takim „zewnętrznym interpretatorem” są organy władzy publicznej w sytuacjach, w których muszą dokonywać wykładni prawa kościołów i innych związków wyznaniowych.

W postępowaniu ze źródłami i literaturą przedmiotu zastosowano kilka metod. Pierwsza z nich to metoda analityczna. Za jej pomocą dokonano wykładni regulacji prawa danego kościoła lub innego związku wyznaniowego oraz jego nauczania doktrynalnego. Drugą metodą była metoda porównawcza, użyta w celu stwierdzenia podobieństw albo różnic w stosunku kościołów i innych związków wyznaniowych do prawa i państwa, a także w odniesieniu do treści klauzul generalnych. Kolejną zastosowaną metodą była analiza krytyczna piśmiennictwa. W pracy odwołano się ponadto do naukowej dyskusji polegającej

8 Por. Postanowienie Trybunału Konstytucyjnego z dnia I2 października 20II r., Ts 329/o8, Lex nr II24545.

9 Por. T. Zieliński, Klauzule generalne w prawie pracy, Warszawa I988, s. 5 . 
na roztrząsaniu niektórych spornych lub niejasnych zagadnień i do krytycznej oceny tej dyskusji. Ostatecznie, przez zastosowanie metody syntezy, zostały sformułowane wnioski i wskazówki dla przedstawicieli doktryny prawa polskiego. Niniejsza praca stanowi novum w polskiej literaturze przedmiotu. O ile bowiem klauzule generalne zostały wszechstronnie opisane w doktrynie prawa polskiego zarówno w ogólnej teorii prawa, jak i nauk dogmatyczno-prawnych ${ }^{10}$, a także w kontekście różnych gałęzi lub dziedzin prawa ${ }^{\text {II }}$ czy też prawa Unii Europejskiej $^{12}$, o tyle brakuje opracowania tych zwrotów w prawie związków wyznaniowych. Można również dodać, że samo prawo religijne to terra incognita dla przedstawicieli doktryny prawa polskiego.

IO Literatura przedmiotu w tym zakresie jest bogata i stale przyrastająca. Dla przykładu można wymienić artykuły w periodykach: J. Nowacki, Niektóre zagadnienia zasad wspótżycia spotecznego, „Państwo i Prawo” (1957) z. 7-8, s. 99-II3; K. Wójcik, Klauzule generalne jako odestania pozasystemowe, „Acta Universitatis Lodziensis Folia Iuridica” (1987) nr 32, s. I23-I44; K. Wójcik, Klauzule generalne jako zwroty wieloznaczne i oceny, „Studia Prawno-Ekonomiczne” 4I (1988), s. 39-6I; L. Leszczyński, Praworzadne stosowanie prawa a klauzule generalne, „Państwo i Prawo” (1989) z. II, s. 56-67; K. Wójcik, Teoretyczna konstrukcja klauzuli generalnej, „Studia Prawno-Ekonomiczne” 49 (I990), s. 42-68; A. Żurawik, Klauzula generalna „dobrych obyczajów”- ujęcie teoretyczne, „Ruch Prawniczy, Społeczny i Ekonomiczny” 7I (2009), s. 35-5I; w monografiach: L. Leszczyński, Klauzule generalne w stosowaniu prawa, Lublin 1986, passim; T. Zieliński, Klauzule generalne w prawie pracy, dz. cyt., passim; Klauzule generalne w prawie krajowym i obcym, red. L. Zacharko, Katowice 20I6, passim.

II Por. A. Stelmachowski, Klauzule generalne w kodeksie cywilnym (Zasady wspótżycia spotecznego - spoteczno-gospodarcze przeznaczenie prawa), „Państwo i Prawo” (I965) z. I, s. 5-20; T. Zieliński, Klauzule generalne w prawie pracy, dz. cyt., passim; M. Safjan, Klauzule generalne w prawie cywilnym (przyczynek do dyskusji), „Państwo i Prawo” (1990) z. II, s. 48-59; E. Rott-Pietrzyk, Klauzula generalna rozsądku w prawie prywatnym, Warszawa 2007, passim; D. Mączyński, R. Sowiński, Klauzule generalne oraz pojęcia niedookreślone w europejskim i krajowym prawie podatkowym a obejście (nadużcie) prawa, [w:] Prawo europejskie - s lat doświadczeń w polskim prawie finansowym. Materiaty konferencyjne (Warszawa, I0-II.06.20I0 r.), red. H. Litwińczuk, Warszawa 20Io, s. 464-478; B. Lanckoroński, Klauzula „rebus sic stantibus” a odpowiedzialność „ex contractu”, „Państwo i Prawo" (2012) z. 3, s. 65-74; A. Choduń, A. Gomułowicz, A. Skoczylas, Klauzule generalne $i$ zwroty niedookreślone $w$ prawie podatkowym $i$ administracyjnym. Wybrane zagadnienia teoretyczne i orzecznicze, Warszawa 2013, passim.

I2 Por. S. Grundmann, D. Mazeaud, General Clauses and Standards in European Contract Law: Comparative Law, EC Law and Contract Law Codification, Hague 2006, passim; M. Szpunar, Wyktadnia klauzul generalnych zamieszczonych w dyrektywach wspólnotowych, [w:] Studia z wyktadni prawa, red. C. Martysz, Z. Tobor, Bydgoszcz 2008, s. II2-I22. 
Opracowanie to, jak już wspominano, ma charakter teoretyczny i praktyczny. $\mathrm{Na}$ fundamencie teoretycznych rozważań zostały bowiem sformułowane, w zakończeniu, praktyczne wskazówki dotyczące postępowania organów polskiej władzy publicznej w przedmiotowym zakresie. Miejmy nadzieję, że będą one przydatne. 


\section{Status prawny kościołów i innych związków wyznaniowych w Rzeczypospolitej Polskiej}

W celu określenia tła rozważań konieczne jest wpierw przedstawienie statusu prawnego kościołów i innych związków wyznaniowych w prawie polskim.

\subsection{Realizacja wolności religijnej w polskim porzacdku prawnym}

Człowiek ze swej natury ma zwykle jakieś potrzeby religijne. Pragnienie religijności jest związane z jego ontyczną strukturą. Uznaje się powszechnie, że człowiek, jako taki, pragnie wyjść ze strefy profanum i wejść w strefę sacrum. Sacrum oznacza wartość typowo religijną, niedającą się precyzyjnie zdefiniować, lecz uznaną za najwyższą i zwykle decydującą o ludzkim losie. Może być ono różnie pojmowane - jako byt osobowy albo bezosobowy, duchowy albo materialny, może mieć charakter moralny albo czysto techniczny. Jednak zawsze sacrum to „coś innego”. Stosunek do „tego czegoś innego” wyraża religia ${ }^{\mathrm{I}}$. Na podstawie powszechności relacji człowieka do sacrum człowiek jest określany jako homo religiosus ${ }^{2}$ lub, w przypadku religii odwołującej się do Boga osobowego, jako capax Dei3 (por. KKK 27-30).

I Por. J. Keller, Religia, [w:] Zarys dziejów religii, red. J. Keller i inni, Warszawa I988, s. 6.

2 Por. M. Elaide, Mity, sny i misteria, przeł. K. Kocjan, Warszawa 1994, passim; syntetycznie zob. G. D. Alles, Homo religious, [w:] The Encyclopedia of Religion, vol. 5, ed. M. Eliade, New York-London 1987, s. 442-445.

3 Por. Augustine, De Trinitate, Brepolis 1968, xiv, 8.II: „Mens eo ipso imago Dei est quo eius capax est” („Umysł jest obrazem Boga, a przez to jest w stanie Boga uchwycić") (przeł. P. Kroczek). 
Ta powszechność doświadczenia religijnego powoduje, że prawo do wolności religii jest jednym z podstawowych praw człowieka przynależnym mu z samej natury (art. I8 Powszechnej Deklaracji Praw Człowieka4). W swojej istocie nie jest to więc prawo nadane, lecz uznane, a jego ujęcie w postaci przepisu nie zmienia jego pierwotnego charakteru. Ułatwia jedynie ochronę i obronę tego prawa.

W języku prawnym prawo do wolności w dziedzinie religii jest zwykle ujmowane przy pomocy terminów: „prawo do wolności sumienia” i „prawo do wolności wyznania” lub wprost „prawo do wolności religii”. Niekiedy utożsamia się wolność sumienia z wolnością wyznania czy wolnością religii, nie dostrzegając między tymi terminami istotnych różnic.

\subsubsection{Wolność sumienia}

Chcąc zdefiniować termin „wolność sumienia”, trzeba najpierw określić, czym jest samo „sumienie”, gdyż z racji stosowania tego pojęcia w tekstach prawnych stało się ono również terminem prawnym.

Należy po pierwsze zauważyć, że polski ustawodawca nie podaje definicji „sumienia”. Istnieje nawet pogląd, że na gruncie prawa nie jest możliwe sformułowanie jego definicjis. Ta opinia wydaje się jednak przesadzona, bowiem definicje sumienia istnieją. ${ }^{6}$ W kwestii poprawnej definicji tego terminu należy się odwołać do pozaprawnej wiedzy przedstawicieli doktryny prawa lub osób

4 Powszechna Deklaracja Praw Człowieka z dnia Io grudnia I948 r. przyjęta i proklamowana rezolucją Zgromadzenia Ogólnego ONZ 217A/III z dnia Io grudnia 1948 r., [w:] Wybór dokumentów prawa międzynarodowego dotyczących praw cztowieka, red. M. Zubik, Warszawa 2008, s. II-I6.

5 Por. J. Nikołajew, Wolność sumienia i religii nieletnich przestępców $w$ zaktadach poprawczych i schroniskach dla nieletnich, „Studia z Prawa Wyznaniowego” I5 (2012), s. I6I.

6 Przykładowo, jeden z autorów, na potrzeby prawa wyznaniowego, definiuje przedmiotowy termin i stwierdza, że sumienie to „świadomość moralna, zdolność wydawania ocen dotyczących wartości moralnej czynów człowieka, w szczególności postępowania samego podmiotu" (H. Misztal, Idea wolności religijnej, [w:] A. Mezglewski, H. Misztal, P. Stanisz, Prawo wyznaniowe, Warszawa 20II, s. 62). Inna definicja, jaką zaproponowano, ujmuje sumienie od strony jego funkcji: „sumienie mówi człowiekowi, jak ma się zachować”; autor stwierdza następnie: „w tym zakresie sumienie jest zarazem normodawcą i sędzią” (R. Sobański, Prawo i moralność, „Śląskie Studia Historyczno-Teologiczne" 32 [I999], s. I60). 
dokonujących wykładni tekstu normatywnego. Chodzi o wiedzę z różnych dziedzin nauki, takich jak np. teologia, filozofia, historia, socjologia, psychologia. Cennym źródłem jest także doświadczenie życiowe.

Uwzględnienie wiedzy pochodzącej z tych źródeł prowadzi do sformułowania definicji na potrzeby nauki prawa. $Z$ punktu widzenia tej dziedziny „sumienie” oznacza „wrodzoną sprawność człowieka do oceny jego indywidualnych czynów, w oparciu o zmienną zdolność posługiwania się prawem wewnętrznym (danym przez Boga), która to ocena wpływa normująco na przyszłe jego zachowania"8. Przy tak pojmowanym sumieniu termin „wolność sumienia” - definiowany w prawie wyznaniowym zwykle jako uprawnienie jednostki do „swobodnego wyboru, kształtowania oraz zmiany poglądów i przekonań w sprawach religii”", lub ujmując sprawę bardziej ogólnie: swego światopoglądu - jest nieadekwatny do treści terminu „sumienie”. W przytoczonej definicji brakuje elementu wartościującego, charakterystycznego dla człowieka kierującego się sumieniem: dla niego sumienie staje się bowiem ukrytym wyznacznikiem jednostkowych zachowań dokonywanych w sposób nieskrępowany. Korzystając z wolności sumienia, człowiek nie tylko dokonuje wyboru swojej relacji do sacrum, ale i wyraża ją poprzez kult prywatny lub publiczny. W wolności sumienia człowiek dokonuje również wyborów związanych z czynnościami życia codziennego.

\subsubsection{Wolność wyznania}

Prawną analizę terminu „wolność wyznania” powinno poprzedzać zdefiniowanie pojęcia „wyznanie”.

W polskim prawie termin „wyznanie” został zdefiniowany w art. 2 pkt I2 Ustawy z dnia 4 marca 2010 r. o narodowym spisie powszechnym ludności

7 Por. J. Nikołajew, Wolność sumienia i religii nieletnich przestępców..., dz. cyt., s. I62. Na temat interdyscyplinarności prawa zob. np. K. Opałek, Interdyscyplinarne związi prawoznawstwa, „Studia Filozoficzne” 2-3 (1985), s. I7-30; J. Gaakeer, Introduction. Multi and Interdisciplinarity: Mere Theory or Just Practice?, „Erasmus Law Review” 3 (2008) issue 3, s. I-2.

8 P. Kroczek, Sumienie w prawie polskim, [w:] Sumienie. Ujęcie interdyscyplinarne, red. B. Gulla, M. Cholewa, Kraków 2015, s. 25.

9 M. Pietrzak, Prawo wyznaniowe, Warszawa 2005, s. 20. 
i mieszkań w 20II r. W słowniczku postanowiono, że ilekroć w tej ustawie mowa o „wyznaniu” lub „przynależności wyznaniowej”, to rozumie się przez to „formalne uczestnictwo lub emocjonalny związek osoby z określonym wyznaniem religijnym, kościołem lub związkiem wyznaniowym”.

W naukach religioznawczych przedmiotowy termin jest stosowany zamiennie z pojęciami „konfesja” lub „denominacja”. Ogólnie mówiąc, oznaczają one konkretną opcję religijną. Te terminy zwykle odnoszą się do Kościołów chrześcijańskich i wspólnot kościelnych powstałych jako niezależne od siebie wspólnoty po podziale Kościoła katolickiego po 1517 r. ${ }^{10}$. Termin „wyznanie” ma więc węższy zakres niż pojęcie „religia”. Jednakże w polskim języku prawnym przedmiotowy termin stał się synonimem pojęcia „religia" (zob. art. 67 ust. 2, art. 8I ust. I i ust. 2, art. 95 Konstytucji z 1952 r. ${ }^{\mathrm{II}}$; art. 53 ust. 7 , art. 233 ust. 2 Konstytucji RP). W polskim prawie ma ono charakter zbiorowy, a także indywidualny, co jest niezgodne z religioznawczym ujmowaniem religii. „Wolność wyznania” definiowana jest jako „uprawnienia jednostki do uzewnętrzniania i manifestowania swych poglądów i przekonań $\mathrm{w}$ sprawach religijnych indywidualnie i zbiorowo, prywatnie i publicznie oraz do postępowania i działania zgodnego ze swoimi przekonaniami" ${ }^{22}$.

Przechodząc do relacji pomiędzy „wolnością sumienia” i „,wolnością wyznania”, należy powiedzieć, że wolność wyznania jest uważana za „przedłużenie lub dopełnienie wolności sumienia, za jej konkretyzację - w zakresie spraw religijnych $-\mathrm{w}$ warunkach współżycia jednostki z innymi ludźmi” ${ }^{13}$.

Zauważmy, że Konstytucja RP w art. 53 ust. I stanowi o „wolności religii”, a nie o „wolności wyznania”. W ustępie 2 przytoczonego artykułu zawierającego listę uprawnień w tym zakresie prawo to zostało w gruncie rzeczy ograniczone do wolności wyboru i praktykowania religii. Nie jest to jednak żadne ograniczenie występującego tradycyjnie w prawie polskim zwrotu „wolność wyznania” (art. 80 ust. I Konstytucji z I952 r.). Jak bowiem słusznie zauważył Trybunał Konstytucyjny: „wolność religii ujmowana [jest - P. K.] w normie konstytucyjnej bardzo szeroko, obejmuje bowiem wszelkie religie i przynależność do wszelkich związków wyznaniowych, a zatem nie jest ona ograniczona

Io Zob. Konfesja i Denominacja, [w:] H. Vorgrimler, Nowy leksykon teologiczny, przeł. i oprac. T. Mieszkowski, P. Pachciarek, Warszawa 2005, s. I52 oraz s. 62.

II Konstytucja Polskiej Rzeczypospolitej Ludowej uchwalona przez Sejm Ustawodawczy w dniu 22 lipca 1952 r. (Dz.U. z 1976 r. Nr 7, poz. 36).

I2 M. Pietrzak, Prawo wyznaniowe, dz. cyt., s. 20.

I3 M. Pietrzak, Prawo wyznaniowe, dz. cyt., s. 20. 
do uczestnictwa we wspólnotach religijnych tworzących formalną, wyodrębnioną strukturę organizacyjną i zarejestrowanych w stosownych rejestrach prowadzonych przez władzę publiczną" ${ }^{4}$. Innymi słowy, realizacja przedmiotowych wolności dotyczy także tych, którzy chcą realizować swoją religijność w formie niezinstytucjonalizowanej lub tych, który uważają się za ateistów i w ogóle nie chcą praktykować religii. Można zatem stwierdzić, że w przypadku wpisanej do art. 48 ust. I Konstytucji RP formuły „wolność sumienia i wyznania” mamy do czynienia z ekwiwalentem występującego w innych miejscach Ustawy Zasadniczej zwrotu „wolność sumienia i religii”. Jest to, jak się wydaje, tylko niejednolitość terminologiczna ${ }^{15}$. Warto przywołać w tym miejscu Wyrok Europejskiego Trybunału Praw Człowieka z dnia 25 maja 1993 r., w którym powiedziano: „[...] wolność myśli, sumienia i religii jest jednym z fundamentów «demokratycznego społeczeństwa» [...]. Jest ona, w swoim religijnym wymiarze, jednym z najbardziej żywotnych elementów, które składają się na tożsamość osób wierzących i ich koncepcję życia, stanowi także cenną wartość dla ateistów, agnostyków, sceptyków i osób obojętnych. Pluralizm jako nieusuwalny element demokratycznego społeczeństwa, zdobywany z trudem przez wieki, zależy od niej”' ${ }^{\text {. }}$.

Trzeba wyjaśnić, że zwrot z preambuły do obowiązującej Konstytucji RP „chrześcijańskie dziedzictwo Narodu” - nie daje żadnych podstaw do twierdzenia, że wolność religii to wolność związana z chrześcijaństwem ${ }^{17}$. Co więcej, w Konstytucji RP brak nawet przesłanek, by uznać, że przez odniesienie się do chrześcijańskiego dziedzictwa ustrojodawca polski stwierdza fakt, iż porządek konstytucyjny państwa ma korzenie w chrześcijańskim systemie wartości ${ }^{18}$.

I4 Wyrok Trybunału Konstytucyjnego z dnia I6 lutego I999 r., sK II/98, Legalis nr 43177 .

I5 Por. T. Zieliński, Pojęcie religii, wyznania, związku wyznaniowego i kościota w Konstytucji Rzeczypospolitej Polskiej, „Prawo i Religia” I (2007), s. 45.

I6 Wyrok Europejskiego Trybunału Praw Człowieka z dnia 25 maja I993 r., I4307/88, Kokkinakis przeciwko Grecji, I4307/88, Legalis nr I35567: „[...] freedom of thought, conscience and religion is one of the foundations of a "democratic society» [...]. It is, in its religious dimension, one of the most vital elements that go to make up the identity of believers and their conception of life, but it is also a precious asset for atheists, agnostics, sceptics and the unconcerned. The pluralism indissociable from a democratic society, which has been dearly won over the centuries, depends on it".

I7 Por. T. Zieliński, Pojęcie religii, wyznania, związku wyznaniowego i kościota $w$ Konstytucji Rzeczypospolitej Polskiej, dz. cyt., s. 34 .

I8 Por. J. Krukowski, Konstytucyjny model stosunków między państwem a Kościotem w III Rzeczypospolitej, [w:] Prawo wyznaniowe w systemie prawa polskiego. Materiaty I Ogólnopolskiego Sympozjum Prawa Wyznaniowego (Kazimierz Dolny, I4-I6 stycznia 
Pomijając sporną kwestię normatywnego autorytetu preambuły do aktu normatywnego ${ }^{19}$, należy stwierdzić, że określa ona kierunek wykładni prawa ${ }^{20}$. $\mathrm{Z}$ racji mocnego powiązania zasad wykładni i reguł redagowania tekstów normatywnych preambuła jest także wskazówką dla stanowienia prawa ${ }^{21}$. Można więc powiedzieć, że polski porządek konstytucyjny nie tylko nie abstrahuje od chrześcijaństwa, lecz kieruje się w stronę realizacji promowanych przez nie wartości, co uwzględnia zarazem także „ogólnoludzkie wartości” (Preambuła, Konstytucja RP). Oczywiście to ukierunkowanie na wartości chrześcijańskie nie jest wyłącznie realizacją woli ustrojodawcy, autora Konstytucji RP, lecz wynika z uwarunkowań historycznych i religijnych Polski. Jednocześnie, co trzeba podkreślić, nie umniejsza gwarancji wolności religijnej.

Należy zauważyć, że wszystkie omawiane wolności są chronione prawem. Kodeks karny w art. 196 penalizuje publiczne znieważenia przedmiotu czci religijnej lub miejsca przeznaczonego do publicznego wykonywania obrzędów religijnych. Przedmiotem ochrony jest wolność przekonań wynikająca z konstytucyjnej zasady wolności sumienia i wyznania, w tym także uczuć obywateli w sprawach wiary i religii ${ }^{22}$. Sąd Najwyższy w swoim orzecznictwie uznał, że wskazany wyżej przepis ochrania „wynikające z wolności sumienia i wyznania - prawo do ochrony uczuć religijnych. Do tych uczuć odnieść

2003), red. A. Mezglewski, Lublin 2004, s. 82. Zob. K. Daniel, Kontrowersje wokót wprowadzenia wartości chrześcijańskich do prawa, [w:] Dynamika wartości w prawie, red. K. Pałecki, Kraków 1997, s. 157-207.

I9 Zob. S. Lewandowski, Charakter normatywny preambuty, „Studia Iuridica” 36 (1998), s. II3-136; oraz szeroko M. E. Stefaniuk, Preambuta aktu normatywnego $w$ doktrynie oraz w procesie stanowienia i stosowania polskiego prawa w latach 1989-2007, Lublin 2009 .

20 Zob. np. A. Choduń, M. Zieliński, Interpretacyjna rola wstępów aktów prawnych, [w:] Wokót konstytucji i zdrowego rozsq̨dku. Prace dedykowane Profesorowi Tadeuszowi Smolinskiemu, red. J. Ciapała, A. Rost, Szczecin-Jarocin 20II, s. I5-25; w perspektywie prawa kanoniczego zob. P. Kroczek, P. Skonieczny, Preamble of Law: Perspective of Legislator and Interpreter, „Angelicum” 90 (2013) fascicle 4, s. 869-888. Por. Wyrok Trybunału Konstytucyjnego z dnia II maja 2005 r., K I8/o4, Legalis nr 68382: „Z tekstu preambuły do Konstytucji nie można wyprowadzić norm prawnych w znaczeniu ścisłym. Niemniej dostarcza ona opartych na autentycznej wypowiedzi ustrojodawcy wskazówek co do zgodnych z jego intencjami kierunków interpretacji przepisów części normatywnej Konstytucji”.

2I Por. S. Wronkowska, Z. Ziembiński, Zarys teorii prawa, Poznań 1997, s. I34.

22 Por. J. Sobczak, Art. 196, [w:] Kodeks karny. Komentarz, red. R. Stefański, Beck Online Komentarze (27.0I.20I4), Legalis nr I2. 
należy wskazany w tym przepisie skutek w postaci ich obrazy" ${ }^{23}$. Przestępstwo określone w tym artykule popełnia ten, kto swoim zamiarem bezpośrednim lub ewentualnym obejmuje wszystkie znamiona tego występku²4.

\subsubsection{Akty normatywne i inne dokumenty dotyczące wolności religijnej}

Skoro prawo do wolności religijnej jest prawem fundamentalnym, to zadaniem państwa jest szanowanie tego prawa oraz jego ochranianie i bronienie ${ }^{25}$. Prawo to jest wszechstronnie zabezpieczone na gruncie prawa międzynarodowego i endogenicznego prawa polskiego ${ }^{26}$. W aktach normatywnych stwierdza się lub przyznaje liczne wolności w tym zakresie bądź zabrania się dyskryminacji ze względu na religię. Do tego zbioru aktów normatywnych zaliczane są w szczególności takie akty, jak:

I. Konstytucja RP - w art. 53 ust. I: „Każdemu zapewnia się wolność sumienia i religii" ${ }^{27}$.

2. Karta Narodów Zjednoczonych z dnia 26 czerwca $1945 \mathrm{r}^{28}$ - art. I ust. 3 , art. I3 ust. I pkt b, art. 55, art. 76 .

3. Międzynarodowy pakt praw obywatelskich i politycznych otwarty do podpisu w Nowym Jorku dnia I9 grudnia 1966 r. ${ }^{29}$ - art. I8 ust. I: „Każdy

23 Uchwała Sądu Najwyższego - Izba Karna z dnia 29 października 2012 r., I KzP I2/I2, Legalis nr 538443 .

24 Por. Uchwała Sądu Najwyższego - Izba Karna z dnia 29 października 2012 r., I KZP I2/I2, Legalis nr 538443 .

25 Przedstawienie genezy prac konstytucyjnych nad obecnymi przepisami wyznaniowymi, ich analizę i realizację po wejściu w życie skrótowo przedstawia A. Łopatka, Prawo do wolności myśli, sumienia i religii, Warszawa 1995, s. 29.

26 Jeżeli chodzi o regulacje dotyczące wolności sumienia i wyznania w innych państwach, zob. E. Schwierskott-Matheson, Wolność sumienia i wyznania w wybranych państwach demokratycznych na przyktadzie regulacji Konstytucji Stanów Zjednoczonych Ameryki, Ustawy zasadniczej Republiki Federalnej Niemiec i Europejskiej konwencji praw cztowieka, orzecznictwa sądów tych krajów oraz Europejskiego Trybunatu Praw Człowieka, Regensburg 2012.

27 Por. P. Leszczyński, Zagadnienia wyznaniowe w Konstytucji RP, Warszawa $200 \mathrm{I}$.

28 Karta Narodów Zjednoczonych, Statut Międzynarodowego Trybunału Sprawiedliwości i Porozumienie ustanawiające Komisję Przygotowawczą Narodów Zjednoczonych z dnia 26 czerwca 1945 r. (Dz.U. z 1947 r. Nr 23, poz. 90 z późn. zm.).

29 Dz.U. z 1977 r. Nr 38, poz. 167. 
ma prawo do wolności myśli, sumienia i wyznania. Prawo to obejmuje wolność posiadania lub przyjmowania wyznania lub przekonań według własnego wyboru oraz do uzewnętrzniania indywidualnie czy wspólnie z innymi, publicznie lub prywatnie, swej religii lub przekonań przez uprawianie kultu, uczestniczenie w obrzędach, praktykowanie i nauczanie”.

4. Międzynarodowy pakt praw gospodarczych, społecznych i kulturalnych otwarty do podpisu w Nowym Jorku dnia I9 grudnia I966 r. ${ }^{30}$-art. 2 ust. 2, art. 13 ust. I i ust. 3.

5. Konwencja o ochronie praw człowieka i podstawowych wolności sporządzona w Rzymie dnia 4 listopada 1950 r. zmieniona następnie Protokołami nr 3 , 5 i 8 oraz uzupełniona Protokołem nr $2^{31}-$ art. 9 ust. I: „Każdy ma prawo do wolności myśli, sumienia i wyznania; prawo to obejmuje wolność zmiany wyznania lub przekonań oraz wolność uzewnętrzniania indywidualnie lub wspólnie z innymi, publicznie lub prywatnie, swego wyznania lub przekonań przez uprawianie kultu, nauczanie, praktykowanie i czynności rytualne".

6. Konwencja (nr III) dotycząca dyskryminacji w zakresie zatrudnienia i wykonywania zawodu przyjęta w Genewie dnia 25 czerwca 1958 r. ${ }^{32}$ - art. I ust. I.

7. Konwencja w sprawie zwalczania dyskryminacji w dziedzinie oświaty sporządzona w Paryżu dnia I5 grudnia 1960 r. ${ }^{33}$ - art. 5 ust. I.

8. Konwencja o prawach dziecka przyjęta przez Zgromadzenie Ogólne Narodów Zjednoczonych dnia 20 listopada 1989 r. ${ }^{34}$ - art. 2 ust. I i ust. 2, art. I4 ust. I i ust. 3 , art. 20 ust. 3 , art. 30.

9. Karta praw podstawowych Unii Europejskiej z dnia 7 grudnia 2000 r. ${ }^{35}$ z protokołem dodatkowym ${ }^{36}$ - art. Io ust. I: „Każdy ma prawo do wolności myśli, sumienia i religii. Prawo to obejmuje wolność zmiany religii lub przekonań oraz wolność uzewnętrzniania, indywidualnie lub wspólnie z innymi,

30 Dz.U. z 1977 r. Nr 38, poz. I69.

3I Dz.U. z 1993 r. Nr 6I, poz. 284.

32 Dz.U. z I96I r. Nr 42, poz. 218.

33 Dz.U. z I964 r. Nr 40, poz. 268.

34 Dz.U. z I99I r. Nr I20, poz. 526; tekst wraz z załącznikiem zawierającym zastrzeżenia i deklaracje strony polskiej.

35 Dz.Urz. UE. C Nr 326 z 2012 r., s. 39I.

36 Protokół (Nr 30) w Sprawie Stosowania Karty Praw Podstawowych Unii Europejskiej do Polski i Zjednoczonego Królestwa (Dz.Urz. UE. C Nr 326 z 20I2 r., s. 313). 
publicznie lub prywatnie, swej religii lub przekonań poprzez uprawianie kultu, nauczanie, praktykowanie i uczestniczenie w obrzędach”.

IO. Ustawa z dnia I7 maja I989 r. o gwarancjach wolności sumienia i wyznania $^{37}$ - art. I ust. I: „Rzeczpospolita Polska zapewnia każdemu obywatelowi wolność sumienia i wyznania” i ust. 2: „Wolność sumienia i wyznania obejmuje swobodę wyboru religii lub przekonań oraz wyrażania ich indywidualnie i zbiorowo, prywatnie i publicznie".

Można ponadto wymienić inne dokumenty, które choć nie mają wprost wiążącego charakteru prawnego, są istotne z punktu widzenia moralnego i politycznego. One także, zgodnie ze swoim charakterem, chronią prawo do wolności religii. Chodzi w szczególności o takie dokumenty, jak:

I. Powszechna Deklaracja Praw Człowieka z dnia Io grudnia 1948 r. przyjęta i proklamowana rezolucją Zgromadzenia Ogólnego oNZ 217A/III z dnia Io grudnia $1948 \mathrm{r}^{38}$.

2. Deklaracja w sprawie wyeliminowania wszelkich form nietolerancji i dyskryminacji opartych na religii lub przekonaniach przyjęta przez onz jako rezolucja Zgromadzenia Ogólnego onz nr 36/55 w dniu 25 listopada I98I r. ${ }^{39}$.

3. Deklaracja w sprawie praw osób należących do mniejszości narodowych lub etnicznych, religijnych i językowych, przyjęta przez onz jako rezolucja Zgromadzenia Ogólnego onz nr 47/135 w dniu Io grudnia $1992 \mathrm{r}^{40}$.

4. Akt Końcowy Konferencji Bezpieczeństwa i Współpracy w Europie zawarty w Helsinkach w dniu I sierpnia I975 r., pkt viII.

Już przytoczona wyżej definicja wolności wyznania oraz zacytowane wybrane przepisy pozwalają na stwierdzenie, że realizacja zasady wolności w dziedzinie

37 Tekst jedn. Dz.U. z 2005 r. Nr 23I, poz. 1965 z późn. zm.

38 Powszechna Deklaracja Praw Człowieka znalazła się w drugim zestawie dokumentów, ponieważ kwestia jej normatywnego charakteru jest problematyczna. Wprawdzie przypisuje się temu dokumentowi pewien „potencjał prawny”, lecz deklaracja nie została uchwalona jako traktat międzynarodowy. Jej celem było wyznaczenie pewnych celów i standardów prawu międzynarodowemu. Zob. R. Kuźniar, Prawa cztowieka: prawo, instytucje, stosunki międzynarodowe, Warszawa 2004, s. 66-67. Nie można mówić jednak, że jest ona tylko „zaleceniem” - tak twierdzą W. Góralczyk, S. Sawicki, Prawo międzynarodowe publiczne w zarysie, Warszawa 2009, s. 266. Istnieje pogląd, że Deklaracja stała się obecnie obowiązująca w wyniku przekształcenia jej postanowień w prawo zwyczajowe międzynarodowe - tak twierdzą R. Bierzanek, J. Symonides, Prawo międzynarodowe publiczne, Warszawa 2005, s. 270-27I.

39 http://libr.sejm.gov.pl/tekor/txt/onz/I98I.html (28.07.2015).

40 http://www.hfhrpol.waw.pl/pliki/deklaracja_praw_osob_nalezacych_do_ mniejszosci_narodowych_lub_etnicznych_religijnych_i_jezykowych_2.pdf (28.07.2015). 
religijnej obejmuje także zaspakajanie potrzeb religijnych $\mathrm{w}$ formie zorganizowanej i uznanej na forum publicznoprawnym, a więc oznacza m.in. swobodne tworzenie wspólnot religijnych, nazywanych w polskim języku prawnym i prawniczym „kościołami i innymi związkami wyznaniowymi” (art. 2 pkt I u.g.w.s.w.).

\subsubsection{Podsumowanie}

W świetle powyższych ustaleń należy stwierdzić, że obowiązujący w Polsce stan normatywny gwarantuje obywatelom i wszystkim objętym polskim prawem pełną swobodę nie tylko religijną, ale i światopoglądową, włączając w to światopogląd ateistyczny. Natomiast neutralność i bezstronność władzy publicznej dotyczą spraw religijnych i spraw przekonań związanych z religią. Konstytucja RP i Ustawa z dnia I7 maja I989 r. o gwarancjach wolności sumienia i wyznania zapewniają poszanowanie „najszerzej pojętych swobód światopoglądowych”"

\subsection{Zakres przedmiotowy terminów „kościół” i „związek wyznaniowy”}

Duża różnorodność cechuje nazewnictwo, które przybierają organizacje religijne. Przyjęły się nazwy „kościół”, „Związek wyznaniowy”, „związek religijny” czy „stowarzyszenie wyznaniowe” lub „wspólnota religijna”. Tym, co je łączy, jest kryterium wyodrębniające je spośród innych organizacji społecznych, a mianowicie wspólny cel, jakim jest zapewnienie wyznawcom możliwości zaspokajania ich potrzeb religijnych ${ }^{42}$.

Pisząc o prawie „kościołów” i „związków wyznaniowych”, trzeba określić, jakie konkretnie podmioty ma się na myśli. Istnieje bowiem rozdźwięk pomiędzy ujęciem tych podmiotów na gruncie prawa polskiego a ujęciem ze strony kościołów i innych związków wyznaniowych.

4I T. J. Zieliński, Ustawa o gwarancjach wolności sumienia i wyznania z I989 r. jako "magna charta" swobód światopogladowych w Polsce, [w:] Prawo wyznaniowe w Polsce (I989-2009). Analizy, dyskusje, postulaty, red. D. Walencik, Katowice-Bielsko-Biała 2009, s. 53.

42 Por. W. Wysoczański, M. Pietrzak, Prawo Kościotów i związków wyznaniowych nierzymskokatolickich $w$ Polsce, Warszawa I997, s. 6-7. 


\subsubsection{Perspektywa państwowa}

Polskie prawo nie definiuje pojęcia „religia” czy „wyznanie”. Co więcej - jak twierdzą niektórzy przedstawiciele doktryny prawniczej - Ustawa Zasadnicza nie daje podstaw do rozstrzygnięć, czy dany zespół poglądów i praktyk jest, czy nie jest religią. Istotne znaczenie w tej mierze mają ustalenia pozakonstytucyjne, a nawet pozaprawne, a w szczególności rozstrzygnięcia filozoficzne, teologiczne, etnograficzne, kulturowe i religioznawcze ${ }^{43}$. Można również uwzględnić intuicyjne rozeznawanie zasadniczej treści tego terminu ${ }^{44}$.

Nie należy jednak bezkrytycznie odwoływać się do definicji wypracowanych przez nauki religioznawcze. Bowiem, choć liczba zaproponowanych definicji religii jest ogromna, to żadna z nich nie spełnia warunków poprawności, gdyż żadna nie charakteryzuje wszystkich religii jako zjawisk niekiedy bardzo specyficznych ${ }^{45}$. Wiele fenomenów społecznych może być przypisanych bezspornie do zjawisk religijnych. Znane są jednakże na terenie religioznawstwa zjawiska pograniczne, które niekiedy spełniają funkcje, jakie zwykło się przypisywać religii ${ }^{46}$.

Sytuacja niedefiniowania prawnego religii może być z jednej strony pożądana. Państwo proklamujące wolność religijną nie musi wcale określać, czym jest religia. Niejako za sprawą nieostrości pojęcia „religia” zrzeka się ono prawa do narzucania formy i treści przeżywania relacji do sacrum.

Z drugiej jednak strony sytuacja taka wprowadza pewną trudność przy podejmowaniu decyzji o uznaniu danej religii i w konsekwencji rejestracji danego kościoła czy innego związku wyznaniowego. Organy władzy publicznej w Rzeczypospolitej Polskiej nie mają oczywiście kompetencji do określania czy oceniania podstaw doktrynalnych wspomnianych organizacji, mają natomiast konstytucyjny obowiązek zachowania bezstronności w sprawach przekonań religijnych (art. 25 ust. 2 Konstytucji RP). Organy rejestracyjne nie dysponują zatem narzędziem do odróżniania autentycznych kościołów lub innych związków wyznaniowych od form zorganizowanej pseudoreligijności, określanych

43 Por. P. Winczorek, Komentarz do Konstytucji Rzeczypospolitej Polskiej z 02.04.1997 r., Warszawa 2000, s. 73.

44 Por. T. Zieliński, Pojęcie religii, wyznania, związku wyznaniowego i kościota w Konstytucji Rzeczypospolitej Polskiej, dz. cyt., s. 30.

45 Por. J. Keller, Religia, dz. cyt., s. 5 .

46 Por. J. Keller, Religia, dz. cyt., s. 5. 
$\mathrm{w}$ literaturze anglojęzycznej jako invented religions ${ }^{47}$, authentic fakes ${ }^{8}$ lub joke religions ${ }^{49}$. Istnienie owych „religii humorystycznych”, nazywanych także „religiami żartu", co oczywiste, nie powinno być zabronione. Jednak ich uznanie prawne i rejestracja przez organ państwowy może powodować obniżenie autorytetu samego organu rejestrującego, prawa, na podstawie którego dokonano rejestracji, a także samego państwa pozwalającego tym organizacjom na uzyskiwanie pewnych korzyści z faktu rejestracji.

Należy jednakże zauważyć, że polskie prawo ramowo reguluje zakres działalności kościołów i innych związków wyznaniowych, stanowiąc, jakie działania mogą podejmować te organizacje w ramach wypełniania swoich funkcji religijnych. Mogą one w tym zakresie m.in. określać doktrynę religijną, dogmaty i zasady wiary oraz liturgię, organizować i publicznie sprawować kult, udzielać posług religijnych, organizować obrzędy i zgromadzenia religijne, rządzić się w swoich sprawach własnym prawem, swobodnie wykonywać władzę duchowną oraz zarządzać swoimi sprawami, ustanawiać, kształcić i zatrudniać duchownych (zob. art. I9 ust. 2 u.g.w.s.w.). Taka regulacja stanowi gwarancję możliwości nadania kościołom i innym związkom wyznaniowym osobowości publicznoprawnej ${ }^{50}$. Może być ona także pomocna przy budowaniu przez doktrynę prawniczą definicji terminu „kościół” czy „związek wyznaniowy”. Brakuje bowiem w prawie polskim pełnej definicji tych pojęć. Istnieje jedynie wewnątrzustawowa definicja w kodeksie karnym wykonawczym ${ }^{5 \mathrm{I}} \mathrm{w}$ art. 242 \ I2: „Użyte w niniejszym kodeksie określenia «kościół», «inny związek wyznaniowy» należy rozumieć jako kościół, inny związek wyznaniowy o ustawowo uregulowanej sytuacji prawnej”. Poza kwalifikatorem w postaci uregulowania prawnego nie mówi ona, czym są te zgromadzenia.

47 Zob. M. Cussack, Invented Religions. Imagination, Fiction and Faith, Burlirigton 2010 .

48 Zob. D. Chidester, Authentic Fakes. Religion and American Popular Culture, Berkeley 2005 .

49 Zob. S. Simpson, Joke Religions: Make Believe in the Sandbox of the Gods, „Ex Nihilo” 6 (20II) nr 2, s. 9I-II8 czy M. Nowicki, “Joke religions” jako nowy model religijności wspótczesnej, „Ex Nihilo” 6 (2011) nr 2, s. 57-90.

50 Por. J. Krukowski, Funkcje publiczne a osobowość publicznoprawna Kościotów, [w:] Funkcje publiczne związków wyznaniowych. Materiaty III Ogólnopolskiego Sympozjum Prawa Wyznaniowego (Kazimierz Dolny, I6-I8 maja 2006), red. A. Mezglewski, Lublin 2007, s. 36.

5I Ustawa z dnia 6 czerwca 1997 r. Kodeks karny wykonawczy (Dz.U. Nr 90, poz. 557 z późn. zm.). 
W oparciu o ustawę o gwarancjach wolności sumienia i wyznania można powiedzieć, że te zrzeszenia to $\mathrm{w}$ świetle prawa polskiego dobrowolne organizacje posiadające własny ustrój, doktrynę i obrzędy kultowe, zakładane w celu zaspokajania potrzeb religijnych swoich członków poprzez wyznawanie i szerzenie wiary religijnej (por. art. I ust. I i 2 oraz art. 2 pkt 2 u.g.w.s.w.).

Przedstawiciele doktryny podkreślają także inne elementy charakterystyczne dla religijnego zrzeszenia, takie jak: zdolność do „wytworzenia organów władzy, które spełniają funkcje wewnętrzne i reprezentują związek na zewnątrz oraz uprawnione są do określania praw i obowiązków swoich członków”s2, czy też „wspólny zespół przekonań” osób w nim zrzeszonych ${ }^{53}$, a także nadrzędny cel tej społeczności, czyli „urzeczywistniania religii” ${ }^{4}$. Nie wydaje się jednak, aby w niniejszych rozważaniach konieczne było wychodzenie poza elementy składowe podanej definicji uzyskane z polskich aktów normatywnych.

W literaturze przedmiotu słusznie wskazuje się, że „kościól” to szczególna nazwa „związku wyznaniowego”, a nie inna kategoria prawna. W nazwie własnej termin „kościół” oznacza zwykle, że opiera się on na doktrynie chrześcijańskiej - tak jest np. w przypadku Kościoła Chrześcijan Baptystów w Rzeczypospolitej Polskiej. Trzeba podkreślić, że związek wyznaniowy sam decyduje o swojej nazwie i nie musi tej cechy, czyli chrześcijańskiego rodowodu, uwzględniaćss. Przykładowo, termin „kościół” jest używany przez neopogański Polski Kościół Słowiański i Rodzimy Kościół Polski oraz Kościół Panteistyczny „Pneuma”. Podsumowując można powiedzieć: „Wszystkie zatem Kościoły są związkami religijnymi, ale nie wszystkie związki wyznaniowe są Kościołami”"s6.

Można dodać jeszcze jedną uwagę. Zważywszy na centralną pozycję pojęcia „religia” jako podstawowego określenia fenomenu regulowanego w art. 25 i art. 53 Ustawy Zasadniczej, z punktu widzenia polskiego języka

52 M. Pietrzak, Prawo wyznaniowe, dz. cyt., s. I3.

53 Por. H. Misztal, Wprowadzenie do prawa wyznaniowego, [w:] Prawo wyznaniowe, red. H. Misztal, P. Stanisz, Lublin 2003, s. 30.

54 T. Zieliński, Pojęcie religii, wyznania, związku wyznaniowego i kościota w Konstytucji Rzeczypospolitej Polskiej, dz. cyt., s. 46.

55 Por. B. Banaszak, Konstytucja Rzeczypospolitej Polskiej. Komentarz, Warszawa 2012 , art. $25 / \mathrm{I}$.

56 J. Cupriak, Zwiazek wyznaniowy, [w:] Leksykon prawa wyznaniowego. Ioo podstawowych pojęć, red. A. Mezglewski, Warszawa 20I4, s. 586-588. 
prawnego lepszy od terminu „związek wyznaniowy” byłby termin „związek religijny" (zob. art. II3 Konstytucji z I92I r.) ${ }^{57}$.

\subsubsection{Perspektywa religijna}

W przypadku uznanych kościołów postrzeganie jakiejś innej struktury religijnej jako kościoła czy związku wyznaniowego uzależnione jest zazwyczaj od doktryny. To ona określa, co jest prawdziwą religią, a w rezultacie - co jest rzeczywiście kościołem lub związkiem wyznaniowym. Kryterium rozpoznawania i kategoryzowania jest zazwyczaj zgodność doktrynalna danej organizacji z doktryną religijną danego kościoła.

\subsubsection{Poglądy Kościoła katolickiego}

Dla Kościoła katolickiego „Kościołem” w sensie ścisłym, czyli „Kościołem Chrystusowym", jest wyłącznie Kościół katolicki. Składa się on z 23 Kościołów ${ }^{58}$. Są to wspólnoty chrześcijan powiązane hierarchią według prawa, wyraźnie lub milcząco uznane przez najwyższą władzę Kościoła jako Kościoły sui iuris (por. kan. $27 \mathrm{KKKW})$.

Kościoły sui iuris cechują się różnymi tradycjami dyscyplinarnymi, ale także teologicznymi i liturgicznymi. Oczywiście, zróżnicowanie pomiędzy Kościołem rzymskim a innymi Kościołami katolickimi jest dużo większe niż pomiędzy Kościołami wschodnimi - stąd też Kościół łaciński rządzi się swoim kodeksem z 1983 r., a pozostałe Kościoły katolickie innym kodeksem z 1990 r. Jednak wszystkie te Kościoły są ,zespolone jednym Duchem” (ipsa unico Spiritu congregata). Dzięki temu Kościół katolicki „niejako przy pomocy dwóch płuc, Wschodu i Zachodu, płonie miłością do Chrystusa jakby jednym sercem z dwiema komorami” (,[Ecclesia Catholica]quasi duobus pulmonibus Orientis et Occidentis respiret atque uno corde quasi duos ventriculos habente in caritate Christi ardeat") ${ }^{59}$.

57 T. Zieliński, Pojęcie religii, wyznania, związku wyznaniowego i kościoła w Konstytucji Rzeczypospolitej Polskiej, dz. cyt., s. 46.

58 Por. Annuario pontificio 20I5, Città del Vaticano 20I5, s. II36-II39.

59 Joannes Paulus Pp. II, Constitutio apostolica Sacri canones Codex Canonum Ecclesiarum Orientalium promulgatur, I8.I0.I990, AAS 82 (I990), s. I037; tekst polski z: Jan Paweł II, Konstytucja apostolska Sacri canones, [w:] Codex Canonum Ecclesiarum 
Wszystkie katolickie Kościoły mają wspólny trzon ustrojowy. Składają się na niego treść wiary zawarta $\mathrm{w}$ dogmatach oraz prawo Boże, które można podzielić na prawo Boże naturalne i prawo Boże pozytywne (ius divinum sive naturale sive positivum - por. can. $27 \$$ I i can. I509 n. I CIC; kan. $199 \mathrm{nr}$ I KPK) ${ }^{60}$. Prawo naturalne jest zakorzenione w stworzeniu. Poznaje się je dzięki rozumowi. Z kolei prawo Boże pozytywne jest poznawane dzięki wierze. Można dodać, że prawo Boże jest więc prawem, od którego z racji teologicznych, nie można dyspensować, czyli zwalniać w poszczególnym wypadku od obowiązku realizowania normy w nim zawartej (kan. $85 \mathrm{KPK}^{6 \mathrm{I}}$ ). Wynika to z tego, iż najwyższym prawodawcą jest Bóg ${ }^{62}$, zaś dyspensa może objąć, co do zasady, tylko leges mere ecclesiastices („ustawy czysto kościelne”) (zob. kan. II KPK), czyli prawo ustanowione przez Kościół, które nie jest logiczną konsekwencją prawa Bożego ${ }^{63}$.

Prawo kanoniczne, jako prawo Kościoła wynikające z jego wiary oraz zawierające prawo Boże, ma tę jedność jeszcze mocniej wyrażać. Jest ono jakby narzędziem zjednoczenia, spajającym cały Kościół ${ }^{64}$. Różne tradycje dyscyplinarne

Orientalium auctoritate Ioannis Pauli PP. II promulgatus, Kodeks kanonów Kościotów wschodnich. Promulgowany przez papieża Jana Pawła II, wydanie łacińsko-polskie, Lublin 2002, s. 33 [dalej: Sacri canones].

60 Por. E. Corecco, Diritto, [w:] Dizionario teologico interdisciplinare, a cura di L. Pacomio, vol. I, Torino 1977, s. I30-I31; T. Gałkowski, Prawo naturalne fundamentem każdego prawa?, „Annales Canonici” 7 (20II), s. I4.

6I Kan. 85: „Dyspensa, czyli rozluźnienie prawa czysto kościelnego w poszczególnym wypadku, może zostać udzielona przez tych, którzy posiadają władzę wykonawczą w granicach ich kompetencji, a także przez tych, którym wyraźnie lub pośrednio przysługuje władza dyspensowania, bądź mocą samego prawa, bądź mocą zgodnej z prawem delegacji” („Dispensatio, seu legis mere ecclesiasticae in casu particulari relaxatio, concedi potest ab iis qui potestate gaudent exsecutiva intra limites suae competentiae, necnon ab illis quibus potestas dispensandi explicite vel implicite competit sive ipso iure sive vi legitimae delegationis").

62 Zob. inne wyłączenia możliwości dyspensowania przedstawione w kan. 86 i 87 KPK. Ich charakter jest pozytywistyczno-prawny, a nie teologiczny.

63 Wyjątkiem od zasady jest dyspensa od małżeństwa zawartego i niedopełnionego udzielona zgodnie z kan. II42: „Małżeństwo niedopełnione, zawarte przez ochrzczonych lub między stroną ochrzczoną i stroną nieochrzczoną, może być ze słusznej przyczyny rozwiązane przez Biskupa Rzymskiego, na prośbę obydwu stron lub tylko jednej, choćby druga się nie zgadzała” („Matrimonium non consummatum inter baptizatos vel inter partem baptizatam et partem non baptizatam a Romano Pontifice dissolvi potest iusta de causa, utraque parte rogante vel alterutra, etsi altera pars sit invita”).

64 Por. Sacri canones, s. 35; Joannes Paulus PP. II, Constitutio apostolica Pastor bonus de Romana Curia, 28.06.1988, AAs 80 (I988), s. 48I-9I2 [dalej: Pastor bonus]; tekst polski: Jan Paweł II, Konstytucja apostolska Pastor bonus o Kurii Rzymskiej, przeł. 
Wschodu i Zachodu są wyrazem różnorodności Kościoła i wynikają z jego uniwersalizmu, czyli otwartości na wszystkich ludzi. Prowadzi to do wielonarodowościowego i wielokulturowego charakteru wspólnoty. Jednak, co należy podkreślić, prawo kanoniczne jest w swoim twardym rdzeniu wyrazem pełnej komunii katolickich Kościołów ${ }^{65}$.

Trzeba dodać, że na określenie Kościoła sui iuris używa się niekiedy terminu ritus („obrządek”). Termin ten zastosowano w wielu kanonach obecnego łacińskiego kodeksu prawa kanonicznego. Należy dla jasności zwrócić uwagę, że nie jest on jednoznaczny, zasadniczo ma bowiem dwa znaczenia. Pierwsze znaczenie „obrządku” to „sposób odprawiania liturgii”. W tym sensie używa omawianego terminu prawodawca przykładowo w kan. 2, kan. $206 \$$ 2, kan. IO34 $\$$ I, kan. III9, kan. I2II kodeksu z 1983 r. Drugie znaczenie to takie, które nadaje temu terminowi kan. $28 \$$ I kodeksu Kościołów wschodnich o brzmieniu: „Obrządek jest dziedzictwem liturgicznym, teologicznym, duchowym i dyscyplinarnym wyodrębnionym przez kulturę i okoliczności historyczne narodów, wyrażającym sposób przeżywania wiary, właściwy dla każdego Kościoła sui iuris" ${ }^{66}$. W tym znaczeniu ten termin występuje w kodeksie lacińskim przykładowo w kan. $372 \$ 2$, kan. $382 \$ 2$, kan. $450 \$$ I, kan. 476, kan. $479 \$ 2$.

Przedmiotowy termin w drugim znaczeniu jest niekiedy równoznaczny z terminem Ecclesia ritualis („Kościół obrządku”) (kan. III \$ I KPK) czy Ecclesia ritualis sui iuris („Kościół samodzielnego obrządku”) (kan. III $\$ 2$ KРК).

Niekatolickie Kościoły chrześcijańskie nie są - w opinii Kościoła katolickiego - „Kościołami w ścisłym sensie” (sensu proprio Ecclesiae non sunt). Są to Communitates ecclesiales, czyli „wspólnoty kościelne” lub „wspólnoty eklezjalne". One nie zachowały bowiem prawomocnego episkopatu oraz właściwej i całkowitej rzeczywistości eucharystycznego misterium ${ }^{67}$.

P. Majer, [w:] Kodeks Prawa Kanonicznego. Komentarz, red. P. Majer, wyd. pol. na podst. wyd. hiszp., Kraków 20II, s. 1397-I465, art. 2.

65 Por. J. D. Faris, An Overview of the Code of Canons of the Eastern Churches, [w:] New Commentary on the Code of Canon Law, ed. J. P. Beal, J. A. Coriden, T. J. Green, New York-Mahwah 2000, s. 4I.

66 Can. $28 \$$ I: „Ritus est Patrimonium liturgicum, theologicum, spirituale et disciplinare cultura ac rerum adiunctis historiae populorum distinctum, quodmodo fidei vivendae uniuscuiusque Ecclesiae sui iuris proprio exprimitur".

67 Por. Congregatio pro Doctrina Fidei, Declaratio Dominus Iesus de Iesu Christi atque Ecclesiae unicitate et universalitate salvifica, 6.08.2000, AAs 92 (2000), nr I7, s. 758-759. 
Należy także dodać, że określenie „Kościół” lub „Wspólnota kościelna” jest zarezerwowane w nomenklaturze katolickiej wyłącznie dla wspólnot chrześcijańskich, czyli tych, które „wyznają Jezusa Chrystusa jako Boga i Pana, oraz jedynego Pośrednika między Bogiem a ludźmi na chwałę jedynego Boga, Ojca i Syna, i Ducha Świętego"68.

Zgodnie z nauczaniem Kościoła inne wspólnoty religijne, szczególnie tradycje religijne, „nierzadko kryją w sobie cenne ziarna prawdy” ${ }^{69}$. Sobór Watykański II w numerze 2 deklaracji Nostra aetate o stosunku Kościoła do religii niechrześcijańskich ${ }^{70}$ stwierdził, że „Kościół katolicki nie odrzuca niczego, co w tych religiach jest prawdziwe i święte. Ze szczerym szacunkiem przypatruje się owym sposobom działania i życia, owym nakazom i doktrynom. Chociaż pod wieloma względami różnią się one od tych, których sam przestrzega i które zaleca, często odbija się w nich promień tej Prawdy, która oświeca wszystkich ludzi”.

\subsubsection{Poglądy Kościołów Reformacji}

Z punktu widzenia protestantyzmu Kościół nie powstał dopiero za czasów Reformacji, lecz Kościół przedreformacyjny jest prawdziwym Kościołem, który w działaniach reformacyjnych znalazł swoją wiążącą kontynuację. Reformatorzy akcentowali, że występują w imieniu „Kościoła katolickiego” lub „Kościoła chrześcijańskiego”. Luter w Dużym katechizmie napisał: „Wierzę, że na ziemi istnieje święta gromadka ludzi i zbór prawdziwie świętych, którego jedyną głową jest Chrystus; zgromadzony przez Ducha Świętego [... . I I ja jestem jego cząstką i członkiem, współuczestnikiem"71. Inny reformator, Filip Melanchton, w Wyznaniu augsburskim pisał o Kościele jako o „zgromadzeniu świętych” (die

68 Sobór Watykański II, Dekret o ekumenizmie Unitatis redintegratio, [w:] Sobór Watykański II, Konstytucje, dekrety, deklaracje, Poznań I986, nr 20.

69 Jan Paweł II, Migracje a dialog międzyreligijny (Orędzie Ojca Świętego na światowy Dzień Migranta 2002 r.), „L'Osservatore Romano” 4 (2002), s. 5.

70 Sacrosanctum Concilium Oecumenicum Vaticanum II, Decretum Nostra aetate de Ecclesiae habitudine ad religiones non-Christianas, 29.I0.1965, AAS 58 (I966), s. 740-744; tekst łacińsko-polski: Sobór Watykański II, Deklaracja o stosunku Kościoła do religii niechrześcijańskich Nostra aetate, [w:] Sobór Watykański II, Konstytucje, dekrety, deklaracje, Poznań 2008, s. 520-527.

7I M. Luter, Duży katechizm, przeł. A. Wantuła, [w:] Księgi wyznaniowe Kościota luterańskiego, Bielsko-Biała 20II, O wierze, art. III, s. Ioo. 
Versammlung aller Glaubigen lub congregatio sanctorum), w którym się wiernie naucza Ewangelii i należycie udziela sakramentów ${ }^{72}$.

Uważa się, że wszystkie Kościoły reformacyjne, czyli Kościoły i Wspólnoty wyrosłe pośrednio lub bezpośrednio z Reformacji, odnoszą się do tego samego pojęcia „Kościół” - Kościoła nieinstytucjonalnego, rozumianego jako społeczność, wspólnota, zgromadzenie lub zbór świętych (communio sanctorum) lub wierzących (communio fidelium) i tym samym uważają się wzajemnie za Kościół Chrystusowy. Dlatego też, gdy chodzi o Kościoły, takie jak: Kościół Ewangelicko-Augsburski, Kościół Ewangelicko-Reformowany oraz Kościół Ewangelicko-Metodystyczny, to na mocy Ugody sandomierskiej z 1970 r. oraz umowy z 1994 r. Kościoły te mają między sobą „wspólnotę ołtarza i ambony” oraz wspólnotę w „rzeczach świętych” (art. I83 PSKE-A). Oznacza to, że uznają siebie jako pełnoprawne Kościoły. Jedynie „Kościołowi rzymskiemu” Marcin Luter odmawiał statusu Kościoła, ponieważ, jego zdaniem, oddalił się od Ewangelii $^{73}$. Uważał go także za narzędzie Antychrysta ${ }^{74}$.

Obecnie Kościołowi katolickiemu przyznaje się powszechnie pełne prawo do eklezjalności. W czasie Europejskiego Zgromadzenia Ewangelickiego w Budapeszcie w 1992 r. jeden z uchwalonych tam dokumentów stwierdzał: „Kościoły ewangelickie są Kościołem Jezusa Chrystusa. Są one jednak świadome faktu, że Kościół Chrystusowy jest obszerniejszy niż one same"7s.

Inne kościoły i związki wyznaniowe nie mają tak jasnych kryteriów uznawania organizacji religijnych za kościoły lub związki wyznaniowe.

\subsection{Relacje państwo - związek wyznaniowy}

Państwo i związek wyznaniowy to dwa różne organizmy. W warunkach Polski są one oddzielone od siebie. Ta diada jest odzwierciedleniem dualistycznego

72 F. Melanchton, Wyznanie augsburskie, przeł. J. W. Jackowski, art. 7, [w:] Księgi wyznaniowe Kościota luterańskiego, dz. cyt., s. I44.

73 Por. A. A. Napiórkowski, Teologia jedności chrześcijan. Podręcznik ekumenizmu, Kraków 20II, s. II5.

74 Por. F. Melanchton, Obrona Wyznania augsburskiego, art. viI i viII O Kościele, $\mathrm{nr}$ 8, [w:] Księgi wyznaniowe Kościoła luterańskiego, dz. cyt., s. 227.

75 K. Karski, Stan recepcji „Lumen gentium” $i$,Unitatis redintegratio” z perspektywy ewangelicko-luterańskiej, [w:] Kościót i dialog: materiaty z sympozjum zorganizowanego z okazji 40. rocznicy promulgacji "Lumen gentium” i "Unitatis redintegratio”, Lublin 2I-22 listopada 2004 roku, red. A. Czaja, L. Górka, V. Kmiecik, Lublin 2005, s. I43. 
widzenia świata obecnego w tradycji myśli chrześcijańskiej ${ }^{76}$, które ma początek w ontologii i eschatologicznej orientacji Kościoła katolickiego ${ }^{77}$. Ten sposób ujmowania relacji państwo - związek wyznaniowy jest obecny we współczesnych systemach wielu demokratycznych laickich państw ${ }^{78}$. Istnieją także inne modele relacji państwo - kościół lub inny związek wyznaniowy ${ }^{79}$. Ich przytaczanie nie jest w tym miejscu jednak potrzebne. Rozważania niniejsze dotyczą bowiem Polski, w której system relacji państwa do religijnych zrzeszeń jest już przyjęty w systemie prawnym.

Przyjmuje się, że obowiązująca w Rzeczypospolitej Polskiej świeckość państwa i bezstronność religijna, światopoglądowa i filozoficzna władz publicznych (art. 25 ust. 2 Konstytucji RP) jest obecnie najbardziej udanym sposobem zapewnienia realizacji zasady wolności religijnej przez państwo ${ }^{80}$. Tylko z laickim państwem mają szansę utożsamić się szerokie rzesze obywateli i tylko takie państwo respektuje pluralizm religijno-światopoglądowy ${ }^{81}$. Oczywiście świecki charakter państwa nie musi oznaczać obojętności religijnej jego obywateli. Państwo laickie to nie kwestia faktu, lecz kwestia prawa ${ }^{82}$.

W celu ukazania stosunku organów władzy publicznej w Rzeczypospolitej Polskiej do prawa kościołów lub innych związków wyznaniowych oraz podania modelowego użycia tego prawa konieczne jest, choćby skrótowe, pokazanie relacji pomiędzy państwem polskim a wspólnotami religijnymi. Można to uczynić, opisując fundamentalne w polskiej rzeczywistości prawnej zasady tych relacji. Stanowią one bazę dla ułożenia szczegółowych relacji pomiędzy tymi podmiotami. Chodzi mianowicie o zasadę autonomii i niezależności wspomnianych

76 Por. R. Sobański, Kościót jako podmiot prawa, Warszawa 1983, s. 200.

77 Por. R. Sobański, Kościót jako podmiot prawa, dz. cyt., s. 217.

78 Poprzez „państwo laickie” czy też „państwo świeckie” należy rozumieć hierarchiczno-instytucjonalną koncepcję państwa, jako struktury organów sprawujących władzę publiczną. Por. P. Borecki, Państwo laickie. Wspótczesna rzeczywistość ustrojowa i perspektywa na przysztość, „Ruch Prawniczy, Ekonomiczny i Socjologiczny” 69 (2007) z. 2, s. 6I, przyp. I. Jednakże, jak zauważono, nie istnieje dotąd w pełni zadowalająca koncepcja takiego państwa. Por. M. Pietrzak, Demokratyczne świeckie państwo prawne, Warszawa 1999, s. I23.

79 Przegląd systematyki stosunków państwa ze związkami wyznaniowymi wraz z przykładami zob. M. Winiarczyk-Kossakowska, Ustawy III Rzeczypospolitej o stosunku państwa do Kościotów chrześcijańskich, Warszawa 2004, s. 27-4I.

80 Por. A. Łopatka, Prawo do wolności myśli, sumienia i religii, dz. cyt., s. 30.

8I Por. P. Borecki, Państwo laickie. Wspótczesna rzeczywistość ustrojowa i perspektywa na przysztość, dz. cyt., s. 6I-79.

82 Por. M. Pietrzak, Demokratyczne świeckie państwo prawne, dz. cyt., s. I3I. 
podmiotów oraz o zasadę równości pomiędzy religijnymi zrzeszeniami względem państwa i polskiego prawa.

\subsubsection{Niezależność i autonomia}

\subsubsection{Perspektywa państwowa}

W prawie polskim zasada niezależności oraz autonomii państwa i związków religijnych została sformułowana w art. 25 ust. 3 Konstytucji RP: „Stosunki między państwem a kościołami i innymi związkami wyznaniowymi są kształtowane na zasadach poszanowania ich autonomii oraz wzajemnej niezależności każdego w swoim zakresie, jak również współdziałania dla dobra człowieka i dobra wspólnego". Zasadę tę wyraża także art. II ust. I ustawy o gwarancjach wolności sumienia i wyznania: „Kościoły i inne związki wyznaniowe są niezależne od państwa przy wykonywaniu swoich funkcji religijnych". Identyczne do konstytucyjnego sformułowanie zawarto w art. I Konkordatu między Stolicą Apostolską i Rzecząpospolitą Polską z $1993 \mathrm{r} \mathrm{r}^{83}$. Ustanowiono w nim, że „Rzeczpospolita Polska i Stolica Apostolska potwierdzają, że Państwo i Kościół Katolicki są - każde w swej dziedzinie - niezależne i autonomiczne oraz zobowiązują się do pełnego poszanowania tej zasady we wzajemnych stosunkach i we współdziałaniu dla rozwoju człowieka i dobra wspólnego".

Ustawy, których adresatami są poszczególne kościoły lub inne związki wyznaniowe, każdorazowo mocno akcentują niezależność i autonomię tych podmiotów względem prawa polskiego ${ }^{84}$. Dla przykładu można podać kilka przepisów: „Kościół rządzi się w swoich sprawach własnym Prawem Wewnętrznym uchwalanym przez Krajową Konferencję Kościoła, swobodnie wykonując swoje funkcje i cele” (art. 3 u.s.p.k.ch.b.), „Kościół rządzi się w swych sprawach własnym prawem, swobodnie wykonuje władzę duchowną i jurysdykcyjną oraz zarządza swoimi sprawami” (art. 2 u.s.p.k.k.), „Kościół rządzi się w swoich sprawach własnym prawem wewnętrznym, uchwalanym przez Kapitułę Generalną, swobodnie wykonuje władzę duchowną i jurysdykcyjną oraz samodzielnie zarządza swoimi sprawami” (art. 2 ust. I u.s.p.k.k.m.).

83 Dz.U. z 1998 r. Nr 5I, poz. 318.

84 Zob. P. Borecki, Autonomia kościołów i innych związów wyznaniowych we wspótczesnym prawie polskim, „Studia z Prawa Wyznaniowego” I5 (2012), s. 85-109. 
Sposób tworzenia wspomnianych ustaw (głównie powstałych po 1989 r.) pokazuje gotowość państwa do zachowania autonomii tych religijnych związków. Ustawy te nie były tworzone jednostronnie i narzucane przez ustawodawcę. Ich podstawą były umowy zawierane przez przedstawicieli kościołów i innych związków wyznaniowych z Radą Ministrów ${ }^{85}$. Doktryna prawna podkreśla, że wykładnia funkcjonalna art. 25 ust. 5 Konstytucji RP wskazuje, że celem ustrojodawcy było zagwarantowanie związkom wyznaniowym realnego wpływu na treść stanowionego prawa w zakresie ich stosunków z państwem. „Wyrażona w art. 25 ust. 5 zasada bilateralności oznacza indywidualne i w pełni konsensualne kształtowanie stosunków Państwa z konkretnym związkiem religijnym" ${ }^{\text {". }}$. Wynika z tego, że uchwalenie nowej wyznaniowej ustawy partykularnej lub nowelizacji ustawy istniejącej już w systemie prawnym (chodzi tylko o nowelizację, która w istotny sposób modyfikuje materialne podstawy wzajemnych relacji) musi opierać się na umowie. Konieczne jest więc wcześniejsze wyrażenie zgodnych oświadczeń dwóch stron (rządowej i wyznaniowej) ${ }^{87}$. W takim duchu wypowiadał się też Trybunał Konstytucyjny: „Z art. 25 Konstytucji wynika ponadto dla organów władzy publicznej obowiązek poszukiwania w sferze stosunków z kościołami i związkami wyznaniowymi rozwiązań prawodawczych o charakterze konsensualnym, które znajdują akceptację adresatów. Ustawodawca nie może zatem podejmować jednostronnych ingerencji w sferę stosunków między poszczególnymi kościołami i związkami wyznaniowymi. Konstytucja RP pozostawia szeroki zakres swobody zainteresowanym kościołom i związkom wyznaniowym oraz Radzie Ministrów w zakresie kształtowania treści prawodawstwa, które ich dotyczy. Swoboda ta nie jest jednak nieograniczona, ponieważ przyjęte rozwiązania prawne muszą być zgodne z normami konstytucyjnymi, w tym m.in. z zasadą równości jednostek oraz zasadą równouprawnienia kościołów i innych związków wyznaniowych"88.

85 Por. W. Skrzydło, Konstytucja Rzeczypospolitej Polskiej. Komentarz, Kraków 2002, s. 37.

86 M. Olszówka, Zawieranie umów i uchwalanie ustaw, o których mowa wart. 25 ust. 5 Konstytucji RP, „Przegląd Sejmowy” (2010) nr 6, s. 50.

87 M. Olszówka, Zawieranie umów i uchwalanie ustaw, o których mowa $w$ art. 25 ust. 5 Konstytucji RP, dz. cyt., s. 56; P. Czarny, Opinia prawna w sprawie obowiazku zasiegania opinii co do zmian w ustawach regulujących stosunek państwa do poszczególnych kościołów i związków wyznaniowych, „Zeszyty Prawnicze Biura Analiz Sejmowych Kancelarii Sejmu” 36 (2012) nr 4, s. 86.

88 Wyrok Trybunału Konstytucyjnego z dnia 2 kwietnia 2003 r., K I3/o2, Legalis nr 56661. 
Niezależność i autonomia podmiotu państwowego i kościoła czy innego związku wyznaniowego zwykle wyprowadzane są z faktu, iż społeczność państwowa i społeczność religijna nie są zależne od siebie w sensie pochodzenia, to znaczy, że żadna z nich nie wywodzi się od drugiej ${ }^{89}$. Natomiast wspomniana niezależność i autonomia warunkowane są rozdzielnością, odmiennością celów realizowanych z jednej strony przez państwo, a z drugiej przez kościoły i związki wyznaniowe ${ }^{90}$.

Można dodać, że zakresy terminów „autonomia” i „niezależność” nie pokrywają się̨" . „Autonomia” pojmowana jest bowiem przede wszystkim w relacjach ad intra - w stosunkach wewnętrznych. Z kolei „niezależność” w relacjach ad extra - w odniesieniu do innej społeczności. Niezależność stanowi zatem najwyższy stopień autonomii ${ }^{92}$.

Niekiedy określając sytuację prawną kościołów i innych związków wyznaniowych, używa się - wbrew polskiemu językowi prawnemu - terminu „samorządność”. Termin ten w kontekście religijnych zrzeszeń oznacza - zdaniem przedstawicieli doktryny - „swobodne wykonywanie władzy duchownej, w tym także jurysdykcji, i zarządzanie swymi sprawami. Samorządność obejmuje też uprawnienie do samodzielnego ustalania struktur organizacyjnych, systemu powoływania organów i trybu ich funkcjonowania"93.

Oczywiście wolność religijna nie jest wolnością absolutną i może być ograniczona w drodze ustawy, ale tylko wtedy, gdy jest to konieczne do ochrony bezpieczeństwa państwa, porządku publicznego, zdrowia, moralności lub wolności i praw innych osób (art. 53 ust. 5 Konstytucji RP, art. 3 ust. I u.g.w.s.w.) ${ }^{94}$. W konsekwencji również niezależność oraz autonomia kościołów i państwa nie mają charakteru absolutnego. Niezależność i autonomia dotyczą bowiem specyficznego dla każdej z tych społeczności zakresu czy dziedziny spraw

89 Por. R. Sobański, Niezależność i autonomia Kościota i państwa podstawowa przestankq konkordatu, „Ateneum Kapłańskie” I27 (1996) z. I, s. I7.

90 Por. B. Banaszak, Konstytucja Rzeczypospolitej Polskiej. Komentarz, dz. cyt., art. $25 / 6$.

9I Por. J. Krukowski, Polskie prawo wyznaniowe, Warszawa 2008, s. 74.

92 Por. J. Krukowski, Polskie prawo wyznaniowe, dz. cyt., s. 74.

93 M. Pietrzak, Prawo wyznaniowe, dz. cyt., s. 259.

94 Szerzej na ten temat zob. M. Granat, Granice wolności religijnej w spoteczeństwie pluralistycznym, [w:] Kultura i prawo: materiaty III Międzynarodowej Konferencji na temat "Religia i wolność religijna w Unii Europejskiej”, Warszawa, 2-4 września 2002, red. J. Krukowski, O. Theisen, s. I73-192. 
(art. 25 ust. 3 Konstytucji RP oraz zob. art. I Konkordatu) ${ }^{95}$. W innych sprawach, które określa się jako causae mixtae (res mixtae), a które leżą na pograniczu kompetencji kościoła i państwa, związki religijne podlegają prawu państwowemu. Do katalogu takich spraw zalicza się zwykle: posiadanie cmentarzy, zawarcie małżeństwa cywilnego w formie wyznaniowej, nauczanie religii, sprawy majątkowe i podatkowe, działalność duszpasterską, administrowanie danymi osobowymi, pomoc społeczną, ochronę dóbr kultury i dziedzictwa narodowego ${ }^{96}$. Kościół czy inny związek wyznaniowy, pełniąc swoją misję w przestrzeni publicznej, ma obowiązek znać i zachowywać regulacje państwowe97.

$\mathrm{Z}$ drugiej strony państwo, nie będąc kompetentne w sprawach religijnych ${ }^{98}$, a także sprawach wewnętrznych związków wyznaniowych, nie tylko respektuje ich prawo wewnętrzne, lecz także dokonuje recepcji norm prawa związów wyznaniowych do prawa polskiego. Dzieje się tak w sytuacji, gdy ustawy państwowe odsyłają do przepisów prawa wewnętrznego związków wyznaniowych. Normy religijne stają się wówczas częścią obowiązującego w państwie porządku prawnego ${ }^{99}$. Jest tak dlatego, iż całkowita izolacja porządków prawnych obu tych społeczności - kościelnej i państwowej, jest w praktyce niemożliwa ${ }^{\text {IoO }}$.

\subsubsection{Perspektywa religijna}

Patrząc na relacje kościołów i innych związków wyznaniowych z państwem z perspektywy religijnej, trzeba pamiętać, że są one uzależnione od tradycji doktrynalnej danej grupy religijnej. Poniżej zostaną przedstawione koncepcje niektórych z nich, a mianowicie tych, które można ukazać na podstawie źródeł

95 Zob. K. Walczuk, Zasada autonomii i wzajemnej niezależności państwa i kościotów oraz innych związków wyznaniowych, [w:] Zasady ustroju politycznego państwa, red. M. Bożek, M. Karpiuk, J. Kostrubiec, K. Walczuk, Poznań 20I2, s. I43; R. Sobański, Prawo kanoniczne a krajowy porządek prawny, „Państwo i Prawo” (I999) z. 6, s. I4-I5.

96 Zob. A. Mezglewski, H. Misztal, P. Stanisz, Prawo wyznaniowe, dz. cyt., s. 158-202.

97 Zob. R. Sobański, Prawo kanoniczne a krajowy porządek prawny, dz. cyt., s. I5.

98 Zob. szeroko o tym T. J. Zieliński, Niekompetencja religijna wtadz publicznych jako aspekt zasady bezstronności z art. 25 ust. 2 Konstytucji RP, [w:] Bezstronność religijna, światopogladowa i filozoficzna wtadz Rzeczypospolitej Polskiej, red. T. J. Zieliński, Warszawa 2009, s. I4I-I67.

99 Por. W. Uruszczak, Recepcja prawa kanonicznego w obowiązujacym prawie polskim, „Annales Canonici” 3 (2007), s. IO-II.

Iоo Por. J. Krukowski, Polskie prawo wyznaniowe, dz. cyt., s. 75-76. 
czysto doktrynalnych lub endogenicznych źródeł normatywnych zawierających elementy doktrynalne.

\subsection{Koncepcja katolicka}

W przypadku Kościoła katolickiego kluczowe w regulacji wspomnianej materii jest nauczanie Soboru Watykańskiego II. Przedstawia ono modelowe relacje pomiędzy Kościołem katolickim a państwem. Mogą być one - jak się wydaje zastosowane w każdym ustroju politycznym ${ }^{\text {ror }}$. Konstytucja Gaudium et spes stanowi, że „Wspólnota polityczna i Kościół są, każde na własnym terenie, od siebie niezależne i autonomiczne" (nr 76). Oznacza to, że Kościół katolicki i państwo są kompetentne każde w swojej dziedzinie. Tym samym wykluczona jest wzajemna ingerencja w działalność charakterystyczną dla każdego z nich ${ }^{102}$. Zdaniem Kościoła czynności specyficznie religijne, takie jak: wyznawanie wiary, pełnienie aktów kultu i sprawowanie sakramentów, uprawianie nauk teologicznych, wzajemne relacje między władzami kościelnymi i wiernymi itp., pozostają poza kompetencją państwa. Nie powinno się ono do nich mieszać, ani w żaden sposób ich wymagać czy utrudniać ${ }^{103}$.

Z drugiej strony Kościół katolicki uważa, że sprawy ziemskie cieszą się słuszną autonomią, przez co rozumieć należy to, że „rzeczy stworzone i same społeczeństwa cieszą się własnymi prawami i wartościami” ${ }^{104}$. Także porządek doczesny państwa należy do tego zbioru. Kościół katolicki chce tę autonomię respektować i nie opowiada się za żadnym konkretnym rozwiązaniem instytucjonalnym czy konstytucyjnym ${ }^{\text {105 }}$. Jednakże „Kościołowi przysługuje prawo głoszenia zawsze i wszędzie zasad moralnych również w odniesieniu do porządku społecznego, oraz wypowiadania oceny o wszystkich sprawach ludzkich, na ile wymagają tego fundamentalne prawa osoby ludzkiej i zbawienie człowieka”

IoI Por. J. Krukowski, Kościót i państwo. Podstawy relacji prawnych, Lublin I993, s. 8I.

IO2 Por. J. Krukowski, Kościót i państwo. Podstawy relacji prawnych, dz. cyt., s. I05; J. Krukowski, Autonomia i niezależność Kościoła i wspólnoty politycznej, „Kościół i Prawo” 4 (1985), s. 5I-77. Por. R. Sobański, Autonomiczność i niezależność Kościoła i państwa, „Przegląd Powszechny” 9 (I994), s. I77-I88.

I03 Congregatio Pro Doctrina Fidei, Nota doctrinalis de christifidelium rationibus in publicis negotiis gerendis, 24.II.2002, AAS 96 (2004) nr 6, s. 366-368.

I04 Sobór Watykański II, Konstytucja duszpasterska o Kościele w świecie współczesnym Gaudium et spes, [w:] Sobór Watykański II, Konstytucje, dekrety, deklaracje, Poznań 2008, nr 36.

IO5 Por. Joannes Paulus II, Litterae enyclicae Centesimus annus, I.05.I99I, AAS 83 (I99I), nr 47, s. 85I-852. 
(kan. $747 \$ 2$ ). Głoszenie nauki przez Kościół to realizacja jego własnej misji i nie można jej rozumieć jako wtrącania się do sprawowania rządów przez poszczególne kraje. Poprzez swoje nauczanie dotyczące spraw społecznych Kościół nie chce uczestniczyć w rządzeniu poszczególnymi krajami. Pragnie jedynie pracować nad kształtowaniem i oświecaniem sumień wiernych, a zwłaszcza tych, którzy poświęcają się życiu politycznemu, aby ich działanie służyło zawsze integralnemu rozwojowi osoby ludzkiej oraz wspólnemu dobru ${ }^{\mathrm{Io}}$.

\subsection{Koncepcja luterańska}

Luterańskie Kościoły powstałe w wyniku Reformacji są tradycyjnie związane z władzą państwową. Uważa się nawet, że „Wyznaniowe pisma protestantyzmu w początkowym okresie - i to wszystkie bez wyjątku - nie są samorozwinięciem się chrześcijańskiej świadomości z własnych swoich głębin, lecz są to raczej dokumenty polityczne, powstałe na gruncie pewnej określonej ówczesnej sytuacji i mieszczące się w ramach pewnego wyraźnie zaznaczonego frontu. Stąd też można je nawet nazwać dokumentami państwowymi, nie tylko dlatego, że powstały z sugestii i inicjatywy zwierzchności państwowej (w Niemczech z inicjatywy poszczególnych książąt Rzeszy czy rad miejskich), lecz i dlatego, że miały być wręcz obroną i ochroną tejże zwierzchności”' ${ }^{\circ \circ}$.

Poglądy Marcina Lutra w zakresie stosunków państwo - Kościół są nadal w Kościołach luterańskich głównym paradygmatem. W Dużym katechizmie największy ojciec Reformacji napisał: „Mówiąc o czwartym przykazaniu [Bożym - P. K.], należy też coś powiedzieć o różnorakim posłuszeństwie wobec przełożonych, którzy mają prawo rozkazywać i rządzić. Z władzy bowiem rodziców wypływa i pochodzi wszelka inna władza. [...] Wszyscy, których nazywa się zwierzchnikami, zajmują miejsce rodziców i od nich muszą wywodzić swą moc i władzę. Dlatego też nazywają się według Pisma ojcami, jako ci, którzy w swych rządach wykonują funkcje ojca i po ojcowsku względem swoich podwładnych postępować powinni. Tak też od dawna Rzymianie i inne narody nazywali panów i panie domów. Patres et matres familias, to jest ojcami i matkami domu. Krajowych panujących i zwierzchników nazywali oni również Patres patriae, tj. ojcami całego kraju, ku wielkiemu naszemu wstydowi, gdyż

I06 Por. Congregatio Pro Doctrina Fidei, Nota doctrinalis de christifidelium rationibus in publicis negotiis gerendis, dz. cyt., nr 6, s. 366-368.

I07 W. Niemczyk, Teologia ksiag wyznaniowych, [w:] Ksiegi wyznaniowe Kościota luterańskiego, dz. cyt., s. 20. 
my, którzy chcemy być chrześcijanami, tak ich nie nazywamy lub przynajmniej za takich nie uważamy i czci im nie oddajemy" ${ }^{\circ 08}$. A w innym miejscu pisał on, że posłuszeństwo w stosunku do świeckiej zwierzchności, która należy do stanu rodzicielskiego i rozciąga się najszerzej, jest religijnym obowiązkiem wierzącego. Przez tę władzę bowiem, „jakby przez naszych rodziców, daje nam Bóg pożywienie, dom i gospodarstwo, ochronę i bezpieczeństwo. Dlatego skoro mają takie imię i tytut, jako oznakę ich najwyższej godności, winniśmy ich czcić i cenić jak najdroższy skarb i drogocenny klejnot na ziemi”' Reformator pisał także: „Byłoby zaś bardzo dobre i nieodzowne, by wszyscy książęta byli dobrymi chrześcijanami. Bowiem miecz i władza jako szczególna służba Boża przystoi chrześcijanom przed wszystkimi innymi na ziemi” ${ }^{11}$. Jednak ostatecznie dla Lutra nie miało aż takiego znaczenia, czy władca jest chrześcijaninem czy też nie. Każda bowiem władza pochodzi z Bożego ustanowienia. W Matym katechizmie w punkcie $O$ zwierzchności świeckiej zalecał on: „Każdy człowiek niech się poddaje władzom zwierzchnim; bo nie ma władzy, jak tylko od Boga, a te, które są, przez Boga są ustanowione. Przeto kto się przeciwstawia władzy, przeciwstawia się Bożemu postanowieniu; a ci, którzy się przeciwstawiają, sami na siebie potępienie ściągają" ${ }^{\text {II }}$. Luter dopuszczał jedynie wystąpienie przeciwko legalnej władzy, gdy zwierzchność staje się niczym apokaliptyczny Szatan, kiedy mają miejsce masowe prześladowania chrześcijan oraz ogłoszono zakaz zwiastowania Ewangeliii ${ }^{112}$.

Należy dodać, że za podstawę relacji państwo - Kościół Luter uważał teorię dwóch władz, które ustanowił Bóg. Pierwsza to władza duchowa, która nie ma miecza, ale Słowo. Drugim rodzajem władzy jest władza doczesna, która działa poprzez miecz. Władza kościelna - „prawa ręka Boga” (Gottes rechte Hand) - ma dbać o sferę duchową, zaś władza państwowa - „lewa ręka Boga” (Gottes linke Hand) - o sferę materialną. „Oddawajcie każdemu to, co mu się należy: komu podatek, podatek; komu cło, cło; komu bojaźń, bojaźń; komu

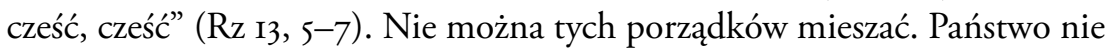

Io8 M. Luter, Duży katechizm, przeł. A. Wantuła, dz. cyt., IV przykazanie, s. 75-76.

Io9 M. Luter, Duży katechizm, przeł. A. Wantuła, dz. cyt., IV przykazanie, s. 76.

IIO M. Luter, O świeckiej zwierzchności, w jakiej mierze należy być jej postusznym, przeł. M Hintz, [w:] M. Luter, Pisma etyczne, red. M. Hintz, Bielsko-Biała 2009, s. I9I.

III M. Luter, Maty katechizm, przeł. A. Wantuła, [w:] Księgi wyznaniowe Kościoła luterańskiego, dz. cyt., s. 54 .

II2 M. Hintz, Neutralność religijna państwa w kontekście luterańskiej nauki..., dz. cyt., s. 2I. 
może przekraczać granic swych kompetencji i narzucać obywatelom rozstrzygnięć, a z drugiej strony władza duchowna nie może wykonywać funkcji władzy świeckiej i ingerować w sprawy, które jej nie podlegają w sprawy nie im podległe ${ }^{\mathrm{II} 3}$.

Dla Lutra zabiegającego o autonomię Kościoła w ramach państwa było oczywiste, iż Kościół powinien być w ścisłym sojuszu z państwem i je wspierać. „Ale ponieważ miecz jest wielkim pożytkiem dla całego świata, by móc utrzymać pokój, ukarać grzech i bronić przed złem, tedy chrześcijanin poddaje się najchętniej pod rząd miecza, płaci podatki, szanuje zwierzchność, służy, pomaga i czyni wszystko, co może a co pomaga władzy, aby zachowana była w zwyczaju, poważaniu i bojaźni, aczkolwiek sam tego dla siebie nie potrzebuje ani nie jest mu to niezbędne" ${ }^{\text {I4 }}$. Dlatego też w konsekwencji Kościół luterański był instrumentem szerzenia ideologii państwowej i pełnił funkcję państwowotwórczą ${ }^{115}$. Z czasem ojciec Reformacji doszedł nawet do przekonania, że w ramach państwa jest miejsce tylko na jeden Kościół państwowy ${ }^{116}$. „Tak więc jest dostatecznie pewne i jasne, że wolą Bożą jest, by posługiwać się świeckim mieczem i prawem jako karą na złych i na ochronę pobożnych" ${ }^{117}$ - pisał.

Nie można przemilczeć tego, że poglądy w sprawie stosunków między państwem i Kościołem już za czasów Reformacji były w gronie luteranów zróżnicowane. Przykładowo „Filipiści byli przekonani, że powinni współpracować z chrześcijańskim zwierzchnictwem także wtedy, gdy książę albo rada miasta chcą bezpośrednio wtrącać się w sprawy kościelne. Gnezjoluteranie byli również zdania, że książę, względnie rada, powinni być «mamką» Kościoła, ale wytyczali ostre granice, które oddzielały władzę państwową od spraw wewnętrznych Kościoła” ${ }^{118}$.

I13 Por. M. Hintz, Neutralność religijna państwa w kontekście luterańskiej nauki..., dz. cyt., s. 23.

II4 M. Luter, Óswieckiej zwierzchności, w jakiej mierze być jej postusznym, dz. cyt., s. I87.

iIs M. Hintz, Neutralność religijna państwa w kontekście luterańskiej nauki..., dz. cyt., s. 22.

II6 Por. T. J. Zieliński, Roger Williams. Twórca nowoczesnych stosunków państwo-kościót, Warszawa 1997, s. I52.

II7 M. Luter, O świeckiej zwierzchności, w jakiej mierze być jej postusznym, dz. cyt., s. I8I.

II8 R. Klob, Jedność wyznania - droga do Formuty zgody, red. i przypisy M. Uglorz, tłum. K. Undas, [w:] Księgi wyznaniowe Kościota luterańskiego, dz. cyt., s. 376. 
Trzeba także dodać, że protestantyzm w swojej historii uległ daleko idącemu instytucjonalnemu, a także doktrynalnemu rozdrobnieniu ${ }^{119}$. Dotyczy to także omawianej kwestii. Przykładowo Kościoły tzw. radykalnej Reformacji (Radical Reformation) odrzucały wszelki przymus w sprawach wiary. Źródeł stosowania przymusu w sferze religijnej upatrywały w zespoleniu państwa i Kościoła ${ }^{120}$.

\subsection{Koncepcja baptystyczna}

Gdy chodzi o baptystów, to zgodnie z art. 13 O wtadzy świeckiej wyznania wiary baptystów polskich z I930 r. ${ }^{\text {I21 }}$, wierzą oni, że „Bóg ustanowił władzę świecką, którą upoważnił do tego, aby uczciwych ludzi broniła, a złoczyńców karała"122. W konsekwencji baptyści poczuwają się do obowiązku okazywania bezwzględnego posłuszeństwa wszystkim przepisom wydanym przez tę władzę, o ile nie ograniczają one wolnego wykonywania obowiązków chrześcijańskich. Jako cel stawiają sobie „cichym i pobożnym życiem ułatwiać jej wykonywanie swoich zadań” oraz, na podstawie Pisma Świętego, uważają za obowiązek modlić się za przełożonych, aby „ze swoich uprawnień korzystali zgodnie z wolą Bożą dla utrzymania pokoju i sprawiedliwości” ${ }^{123}$.

\subsection{Koncepcja metodystyczna}

Relacje metodystów do państwa omawiają Zasady socjalne, a szczególnie nr v zatytułowany Wspólnota polityczna. Według podanych tam reguł celem władzy publicznej jest ochrona praw człowieka oraz utrzymanie ładu społecznego.

Jeżeli chodzi o bezpośrednie relacje państwa i Kościoła, to „Państwo nie powinno zmierzać do kontroli w stosunku do Kościoła, podobnie Kościół nie powinien dążyć do dominacji nad Państwem. «Rozdział Kościoła od Państwa» nie oznacza organicznej jedności, ale pozwala na współdziałanie. Kościół nieustannie powinien wywierać mocny wpływ etyczny na Państwo, wspomagając

II9 Zob. Z. Pasek, Wyznania wiary protestantyzmu. Tom zawiera także wyznania wspólnot religijnych XIX i XX wieku wywodzacych się z dziedzictwa reformacji. Wybór tekstów źródtowych, Kraków I995, s. 6-7.

I20 Por. T. J. Zieliński, Roger Williams. Twórca nowoczesnych stosunków państwokościót, dz. cyt., s. I50.

I2I Konfesja, czyli wyznanie wiary i ustrój zborów baptystów, Ostrzeszów 1930. Uwspółcześniona wersja została wydana pod tytułem: Wyznanie wiary baptystów polskich z 1930 r., Warszawa 2000.

I22 Wyznanie wiary baptystów polskich z 1930 r., dz. cyt., art. I3.

I23 Wyznanie wiary baptystów polskich z 1930 r., dz. cyt., art. I3. 
jego politykę i programy służące sprawiedliwości, a przeciwstawiając się polityce i programom, które są niesprawiedliwe" ${ }^{224}$.

Członkowie Kościoła metodystów powinni darzyć szacunkiem także prawo państwowe i przestrzegać go, o ile jest ono legalnie ustanowione i sprawiedliwie wykonywane przez właściwe organy. Jeżeli nakaz prawa jest niezgodny z sumieniem, to po wyczerpaniu wszystkich możliwości prawnych godziwy jest sprzeciw lub nieposłuszeństwo wobec prawa ${ }^{125}$. Oczywiście wierność Bogu jest dla Kościoła metodystów ważniejsza niż wierność państwu i jego prawu (por. Dz 5, 29) ${ }^{126}$.

\subsection{Koncepcja mariawicka}

Gdy chodzi o Kościół Starokatolicki Mariawitów, to w statucie tego Kościoła w art. II $\$ I stanowi się, że „Kościół Mariawicki jest niezależny od jakiejkolwiek władzy obcokrajowej, duchowej czy świeckiej”. Z przepisu wynika, że chodzi o władzę obcokrajową, a nie władzę krajową. Oznacza to, że ten mariawicki Kościół dokonał w statucie samoograniczenia swoich praw na rzecz państwa polskiego. Przykładowo w art. II $\$$ II, art. II $\$$ I3 , art. II $\$$ I4 wspominanego statutu poszczególne kompetencje władz Kościoła odnośnie do: zmiany granic diecezji i tworzenia nowych diecezji ${ }^{127}$, mianowania na wszystkie stanowiska w Kościele czy przyjmowania zapisów i darowizn w formie nieruchomości wymagają uzgodnienia z władzami państwowymi. Także prawo niezależnego stanowienia prawa wewnętrznego Kościoła zostało mocno ograniczone. Przepis art. XIV \ I stanowi, że „Zmiany Statutu Kościoła Starokatolickiego Mariawitów następują na drodze uchwał Synodu Kapituły i zatwierdzone [są - P. K.] przez właściwe władze państwowe”.

Z kolei statut Kościoła Mariawitów w Rzeczypospolitej Polskiej nie tylko nie zawiera przepisu podkreślającego niezależność tego Kościoła, lecz wprost zawiera normę o zależności tej organizacji religijnej od państwa w $\$ 43$ : „Zmiany

I24 Zasady socjalne 2000-2004: nauka spoteczna Zjednoczonego Kościoła Metodystycznego, red. Z. Kamiński, red. merytoryczna E. Puślecki, Warszawa 2003, V, B [dalej: Zasady socjalne].

I25 Por. Zasady socjalne, dz. cyt., V, E.

I26 Por. Zasady socjalne, dz. cyt., V, A.

I27 Nota bene prawo państwowe uznaje, że „Kościół samodzielnie tworzy, przekształca i znosi jednostki organizacyjne, w tym także posiadające osobowość prawną” (art. 5 ust. I u.s.p.k.m.). Dla uzyskania osobowości prawnej kościelnej wystarczy jedynie powiadomienie właściwego organu przez władzę kościelną (art. 5 ust. 3 u.s.p.k.m.). 
statutu Kościoła mogą nastąpić na wniosek Rady Przełożonych w drodze uchwały Kapituły Generalnej w porozumieniu z właściwymi Władzami Państwowymi” oraz $\$ 44:$ "Niniejszy statut przyjęty przez Generalną Kapitułę Kościoła dnia I4 maja 1967 r. wchodzi w życie z dniem jego zatwierdzenia przez odpowiednie Władze Państwowe”.

Oznacza to, że ustawy wewnętrzne Kościołów mariawickich ograniczają autonomię i niezależność tych związów wyznaniowych na rzecz państwa polskiego. Może pojawić się argument, że wskazane przepisy nie odzwierciedlają poglądów tych kościołów, lecz są pozostałością po czasach, w których władza państwowa próbowała podporządkować sobie wszystkie związki wyznaniowe. Jednakże po 1989 r. państwo polskie przyznało związkom wyznaniowym swobodę, wprowadzając zasadę autonomii i niezależności w ich relacje z państwem. I choć obecnie owe samoograniczające przepisy nie są w pełni realizowane - w praktyce, dla przykładu, Kościół Starokatolicki Mariawitów informuje jedynie o zmianie na stanowisku osób prezentujących osoby prawne $^{\text {I28 }}$ - to utrzymywanie przez oba Kościoły wskazanego stanu prawnego przez 28 lat od wejścia w życie ustawy o gwarancjach wolności sumienia i wyznania przy posiadaniu przez Kościoły mariawickie nowoczesnej własnej ustawy indywidualnej jest możliwe do wytłumaczenia tym, że po prostu koncepcję relacji z państwem opartą na swoim podporządkowaniu państwu przyjmują oba te związki wyznaniowe.

\subsection{Koncepcja staroobrzędowa}

W przypadku Kościoła staroobrzędowców wykładnię jego stosunku do państwa można znaleźć w statucie tego Kościoła z I984 r., który był po 1989 r. nowelizowany. Ten akt normatywny mocno ogranicza autonomię i niezależność Kościoła staroobrzędowców na rzecz Rzeczypospolitej Polskiej. Wprawdzie statut tego Kościoła w $\$$ I zawiera deklarację, że Kościół ten rządzi się przepisami swego prawa kanonicznego i statutem oraz posiada ustrój i własny zarząd wewnętrzny autonomiczny i niezależny, jednak inne regulacje dotyczące tegoż Kościoła oddają wiele kompetencji typowych dla władzy kościelnej w ręce państwowej władzy publicznej.

Chodzi przykładowo o samostanowienie związku wyznaniowego. Zgodnie z obowiązującym statutem uchwalanie statutu i jego zmiany uchwalane przez

I28 Wywiad z biskupem M. L. Jabłońskim (archiwum prywatne autora, sygn. $\mathrm{KSM} / \mathrm{I})$. 
Ogólnopolski Sobór podlegają zatwierdzeniu przez Urząd do spraw Wyznań ( $\$$ Io pkt 6 swKs). Trzeba dodać, że uchwały w sprawach wiary i moralności są zawsze autonomiczną decyzją soboru. Natomiast te uchwały soboru, które nie dotyczą wiary i moralności, przekazuje się do ogłoszenia Naczelnej Radzie Staroobrzędowców, a ta przed dokonaniem ogłoszenia upewnia się, czy Urząd do spraw Wyznań nie wnosi sprzeciwu wobec treści uchwały ( I4 swKs). W przypadku tworzenia i znoszenia podstawowych jednostek administracyjnych, czyli gmin, staroobrzędowcy swoje decyzje muszą przedkładać właściwym organom administracji państwowej stopnia wojewódzkiego z wnioskiem o zatwierdzenie ( $\$ 34$ swks). Także członkowie Naczelnej Rady Staroobrzędowców przed objęciem urzędowania winni uzyskać w Urzędzie do spraw Wyznań uznanie swego wyboru i złożyć przysięgę, w której rocie jest zobowiązanie do wypełniania obowiązów zgodnie „z pismem Świętym, Kanonami Kościoła, postanowieniami zwierzchniej Władzy Duchownej Kościoła w Polsce oraz zasadami Konstytucji Rzeczypospolitej Polskiej”, a także do bycia „wiernym jej obywatelem” (\$ I7 SwKs). Bliskie powiązanie Kościoła staroobrzędowców i państwa uwidacznia się w przepisach zakazujących „działania sprzecznego z interesem RP” ( $\$$ 5O lit. f swKs), „szkodliwej dla dobra Kościoła i Państwa lub karygodnej działalności” ( $\$ 48$ swKs). Warto zwrócić uwagę na charakterystyczne połączenie w tym przepisie dobra obydwu struktur, które jest wyrazem stosunku tego Kościoła do państwa.

Wydaje się, że w statutach innych kościołów czy związków wyznaniowych brak przepisów tak mocno chroniących interesy państwa, jak to ma miejsce w omawianym statucie. Uwzględniając fakt, że po 1989 r. podczas nowelizacji tego aktu normatywnego nie zdecydowano się na usunięcie przepisów podporządkowujących państwu omawiany Kościół, można przypuszczać, że model relacji z państwem oparty na samoograniczeniu staroobrzędowców jest przez ten związek wyznaniowy modelem pożądanym. Inną sprawą jest to, że pewne elementy zależności tego związku wyznaniowego od państwa spisane są w Rozporządzeniu Prezydenta Rzeczypospolitej z dnia 22 marca 1928 r. o stosunku Państwa do Wschodniego Kościoła Staroobrzędowego, nie posiadającego hierarchji duchownej ${ }^{129}$, które obowiązuje i jest aktem wyższego rzędu niż statut (zob. np. art. I, art. 5 r.s.p.w.k.s.). 


\subsection{Koncepcja islamska}

W przekonaniu muzułmanów państwo musi kierować się prawem religijnym - islamskim, które zbudowane jest na koncepcji wspólnoty muzułmańskiej (ummy). Termin umma oznacza społeczność wiernych, wspólnotę wyrażającą się we wierze i praktyce życia religijnego ${ }^{130}$. Umma zawsze była pojmowana jako jedność tak wielka, że żadne systemy interpretacyjne, światopoglądowe, wewnętrzne konflikty nie wpływały na osłabienie jej integralności. Owe wspólne cechy ummy sprowadza się przeważnie do takich elementów, jak m.in.: wiara w jednego Boga (Allacha), wspólne rytuały (takie jak modlitwa, miesięczny post), jednolita organizacja rodziny i rola kobiety w społeczności, ale także wspólne prawo spadkowe, wymierzanie sprawiedliwości w oparciu o prawo koraniczne, wyodrębnienie cmentarzy zarezerwowanych dla muzułmanów, zakazy dotyczące spożywania napojów alkoholowych czy mięsa ze zwierząt zabitych niezgodnie $\mathrm{z}$ rytuałem ${ }^{\mathrm{I} 3 \mathrm{I}}$.

Tak więc religia, moralność oraz prawo państwowe w koncepcji muzułmańskiej są ze sobą ściśle związane. Co więcej, żadne państwo muzułmańskie nie może zawierać sojuszu z państwem niemuzułmańskim, gdyby sojusz taki miał szkodzić interesom innego państwa muzułmańskiego. Interesy islamu powinny przewyższać wszelkie inne interesy ${ }^{132}$. Należy dodać, że muzułmanie muszą dążyć do zaangażowania w zarządzanie państwem, w którym mieszkają. Nie mogą zrezygnować $\mathrm{z}$ tego obowiązku, gdyż został nałożony na nich przez Boga ${ }^{133}$.

Można powiedzieć, że w koncepcji muzułmańskiej widać wyraźne dążenie do absolutnej dominacji prawa religijnego nad prawem państwowym, a nawet, że prawo religijne ma docelowo stać się prawem państwa. Państwo w myśli teologicznej islamu to bowiem państwo religijne. Państwo i relacje społeczne mają być kształtowane przez religię.

W warunkach polskich widać pewną, nałożoną przez ustawę o stosunku państwa do Muzułmańskiego Związku Religijnego w Rzeczypospolitej

I30 Por. M. F. Denny, Umma, [w:] The Encylopaedia of Islam, ed. P. J. Bearman and others, vol. Io, Leiden 2000, s. 859. Należy pamiętać, że idealny wzorzec ummy nigdzie nie funkcjonuje.

I3I Por. A. Mez, Renesans islamu, Warszawa 1979, s. I7-I8.

I32 Por. Święty Koran. Tekst arabski i ttumaczenie polskie, tłumaczenie oparte na przekładzie Malik, Ghulam, Farid, Tilford I996, s. I32, przyp. 395.

I33 Por. Democracy, [w:] O. Leaman, L. Ali, Islam. The Key Concepts, London-New York 2008, s. 25. 
Polskiej, supremację państwa nad tym związkiem wyznawców islamu. Wyraźnie na to wskazują choćby przepisy dotyczące muftiego, który może być wybrany dopiero po uprzednim upewnieniu się, że minister wyznań religijnych i oświecenia publicznego nie wnosi wobec ich wyboru sprzeciwu (art. 6 ust. I u.s.p.m.z.r.). Wybór muftiego podlega zatwierdzeniu Prezydenta Rzeczypospolitej (art. 9 u.s.p.m.z.r.). Mufti-elekt jest zobowiązany złożyć na ręce ministra wyznań religijnych i oświecenia publicznego przysięgę według roty, która nakazuje m.in. przestrzeganie praw Rzeczypospolitej przez muftiego i podwładne mu duchowieństwo, zachowanie wierności Rzeczypospolitej, szanowanie rządu, troskę o dobro Rzeczypospolitej i powstrzymanie się od uczestnictwa w poczynaniach, które by mogły przynieść szkodę państwu polskiemu lub porządkowi publicznemu (art. 9 u.s.p.m.z.r.). Pewną dominację państwa nad związkiem widać także w art. 34 ust. I przedmiotowej ustawy. Wspomniany przepis narzuca związkowi intencję modlitwy i nakazuje, aby podczas nabożeństwa w piątki każdego tygodnia oraz w uroczyste święta duchowni muzułmańscy odmawiali modlitwy za pomyślność Rzeczypospolitej i prezydenta. W święta państwowe muzułmanie mają natomiast odprawiać uroczyste nabożeństwo „na intencję Rzeczypospolitej, Jej Prezydenta, Rządu i Wojska”. Jednakże wskazane regulacje wcale nie muszą odpowiadać poglądom doktrynalnym tego związku wyznaniowego. Ustawa z 1936 r. była aktem jednostronnie narzuconym przez państwo. Także Statut Muzułmańskiego Związku Religijnego w Rzeczypospolitej Polskiej z dnia 26 sierpnia 1936 r. zawiera zgodne z tą ustawą rozwiązania prawne, które tę supremację państwa umacniają (zob. $\$ 47, \$ 49$ ust. I i ust. 2 SMZRI936). Nota bene ani wskazane postanowienia ustawy, ani statutu nie są realizowane ${ }^{\mathrm{I} 34}$.

Natomiast według Statutu Muzułmańskiego Związku Religijnego w Rzeczypospolitej Polskiej z dnia 28 lutego 2009 r. ta sprawa wygląda inaczej. Nie ma tam żadnego z wymienionych wyżej przepisów wskazujących na dominację państwa w relacjach z tym związkiem wyznaniowym.

W kontekście powyższego należy odnotować jeszcze jedną zagadkową kwestię, wynikającą z analizy porównawczej dwóch dokumentów. Pierwszy

I34 Należy odnotować fakt, że jak wynika z informacji przekazanej przez Ministerstwo Spraw Wewnętrznych i Administracji, obecny mufti Tomasz Miśkiewicz nie składał przysięgi, o której mowa w art. 9 ustawy; zob. Pismo Podsekretarza Stanu S. Chwałka z Ministerstwa Spraw Wewnętrznych i Administracji z dnia Is grudnia 2015 r. do autora, DWRMNIE-WRPiFK.0I33I2.20I5 (archiwum prywatne autora, sygn. MSWiA/2). 
z nich to propozycja Muzułmańskiego Związku Religijnego w Rzeczypospolitej Polskiej ${ }^{135}$ dotycząca nowelizacji ustawy z 1936 r. o stosunku państwa do tego związku. Drugi dokument to odpowiedź strony rządowej na powyższe pismo w postaci własnej propozycji nowelizacji tejże ustawy ${ }^{136}$. Między tymi projektami istnieją znaczące różnice w modelu ułożenia stosunków pomiędzy muzułmanami zrzeszonymi w tym związku wyznaniowym a państwem polskim. Różnice te, uogólniając, polegają na tym, że model stosunków państwo związek proponowany przez muzułmanów jest modelem, w którym państwo nadal ma pewne nadzorcze lub kontrolne kompetencje względem związku. Przykładowo, projekt ten podtrzymuje - aczkolwiek w zmienionej formule i przed innym organem państwowym - wspomniany wyżej obowiązek składania przez muftiego przysięgi wierności Rzeczypospolitej. Z kolei model zawarty w propozycji rządowej jest modelem liberalnym, realizującym zasady i przepisy Konstytucji RP oraz ustawy o gwarancjach sumienia i wyznania z 1989 r. Niezrozumiałe jest to, że Muzułmański Związek Religijny sam, niezgodnie z muzułmańskim doktrynalnym nauczaniem, wyszedł z propozycją podtrzymania znanych z ustawy z 1936 r. nadzorczych lub kontrolnych kompetencji państwa.

\subsection{Koncepcja karaimska}

Trudno precyzyjnie ustalić, jaki jest stosunek karaimów do państwa. Brakuje źródeł pisanych w tym zakresie, stworzonych przez ten związek wyznaniowy. Nie ma także oficjalnego stanowiska związku w tej sprawie. Poglądy na tę kwestię są indywidualną sprawą członków tego związku wyznaniowego ${ }^{137}$.

I35 Projekt nowelizacji Ustawy z dnia 2I kwietnia 1936 roku o stosunku Państwa do Muzułmańskiego Związku Religijnego w Rzeczypospolitej Polskiej, przekazany do Ministerstwa Administracji i Cyfryzacji przez xx Nadzwyczajny Kongres Muzułmańskiego Związku Wyznaniowego w RP pismem z dnia 7 stycznia 20I5 r. Załącznik do pisma Departamentu Bezpieczeństwa, Ministerstwa Spraw Wewnętrznych i Administracji z dnia I7 października 2016 r. do autora, Nr DBI-Wodouip-o667-I-IOI/20I6 (archiwum prywatne autora, sygn. MswiA/3).

I36 Propozycja nowelizacji Ustawy z dnia 2I kwietnia 1936 roku o stosunku Państwa do Muzułmańskiego Związku Religijnego w Rzeczypospolitej Polskiej, którą Ministerstwo Administracji i Cyfryzacji przekazało Muzułmańskiemu Związkowi Wyznaniowemu w RP pismem z dnia 7 sierpnia 20I5 r. Załącznik do pisma Departamentu Bezpieczeństwa, Ministerstwa Spraw Wewnętrznych i Administracji z dnia I7 października 2016 r. do autora, Nr DBI-WODOUIP-0667-I-IOI/20I6 (archiwum prywatne autora, sygn. MSwiA/3).

I37 List S. Pileckiego (Przewodniczącego Zarządu Karaimskiego Związku Religijnego) z dnia I4.IO.20I5 r. (archiwum prywatne autora, sygn. KZR/I). 
Statut omawianego związku wyznaniowego z roku 1973 r. (nowelizowany w 2oII r.) zawiera nieliczne przepisy, które przedmiotowy stosunek prezentują niejasno. Pozwalają one jednak na stwierdzenie, że karaimowie uznają w pewnym zakresie władztwo państwa nad sobą. Wprawdzie $\$$ I tego aktu normatywnego orzeka, że ich związek wyznaniowy jest „samodzielny i niezależny w swym ustroju i zarządzie od jakiejkolwiek obcokrajowej władzy duchownej lub świeckiej i rządzi się własnymi przepisami religijnymi w ramach niniejszego statutu oraz obowiązujących praw państwowych", to jednak redakcja tego przepisu pozwala na stwierdzenie, że karaimowie uznają kompetencje polskiej władzy państwowej w zakresie swoich spraw wewnętrznych. Dodatkowo $\bigotimes_{3 I}$ statutu przewiduje, że hazzanów i ochuwczu, czyli osoby sprawujące duchowe zwierzchnictwo nad dżymatem (karaimską gminą wyznaniowa) wybiera ogólne zebranie członków gminy. Kandydatów zatwierdza na stanowiskach Zarząd związku po upewnieniu się, czy władze państwowe nie zgłaszają zastrzeżenia wobec tych osób. Inne przepisy statutu nakazują ogólnie poszanowanie prawa państwowego w określonym zakresie (\$ I, \ I8 lit. j, \27), co niekoniecznie musi oznaczać uznanie modelu podporządkowującego związek władzy publicznej.

Można nadmienić, że ustawa indywidualna dla tego związku z 1936 r. narzuciła pewne rozwiązania w zakresie relacji z państwem, mocno podporządkowując ten związek państwu polskiemu. Jednakże, z racji procedury stanowienia tej ustawy, jej przepisy wcale nie muszą być uznawane przez wyznawców za własne i w konsekwencji nie mogą być traktowane jako odzwierciedlające poglądy tego związku wyznaniowego.

\subsection{Koncepcja żydowska}

Aby ustalić, jaki jest stosunek religii żydowskiej do państwa, należy się odwołać do reguły Dina d'Malkhuta dina z Talmudu Babilońskiego ${ }^{\mathrm{I} 38}$. Występuje ona w nim wielokrotnie w traktatach: Nedarim 28a, Gittin ıob, Bava Kama Inzb, Bava Batra 54b. Reguła ta odzwierciedla stosunek do prawa państwowego, lecz pośrednio ukazuje również stosunek do państwa jako twórcy tego prawa.

Wspomniana reguła oznacza, że należy przestrzegać prawa państwowego tak wiernie, jakby było pochodzenia religijnego. Ta reguła ma być stosowana, o ile prawo państwowe nie jest sprzeczne z prawem Bożym. A jest ono sprzeczne wtedy, gdy nakazuje zachowania sprzeczne z prawem religijnym lub zakazuje

I38 The Babylonian Talmud, ed. I. Epstein, London 1952, wersja online: http:// www.come-and-hear.com/talmud/index.html (I8.09.2015). 
zachowań wymaganych od wiernych przez prawo religijne ${ }^{139}$. Trzeba także wspomnieć, że jeśli prawo państwowe dopuszcza zachowania nie tyle sprzeczne z prawem religijnym, ile religijnie szkodliwe ze względu na zgorszenie społeczności żydowskiej, to prawa państwowego nie wolno realizować. Zasada ta nie dotyczy relacji pomiędzy samymi żydami. W tych sprawach bowiem należy stosować nie prawo państwa, lecz cywilne prawo talmudyczne ${ }^{140}$.

Wartość normatywna omawianej reguły została określona w Schulchan Aruch $^{\text {I11 }}$, czyli w kodeksie prawa żydowskiego w części Choshen Mishpat 369:8, w którym jest mowa o królu (a więc o ustawodawcy świeckim) i o królestwie (czyli terytorium, na którym obowiązuje prawo). Żydzi mają zatem stosować prawo państwowe obowiązujące tam, gdzie się znajdują. Pośrednio oznacza to, że stosunek do państwa jest oparty na obowiązku religijnego posłuszeństwa.

\subsection{Podsumowanie}

Przedstawione wyżej poglądy na temat stosunków państwo - związek wyznaniowy oddają całe spektrum możliwych modeli tych relacji - od podporządkowania państwu poprzez niezależność do pragnienia podporządkowania sobie państwa. Można powiedzieć, że kościoły i inne związki wyznaniowe mają doktrynalne koncepcje swoich relacji z państwem. Nie są one jednak tak samo rozbudowane czy szczegółowe. Niekiedy w ogóle brakuje wypracowanych przez związek religijny doktrynalnych źródeł pisanych w tym zakresie. Niejednokrotnie nie ma także oficjalnego stanowiska związku w tej sprawie. Poglądy na tę kwestię są wówczas indywidualną sprawą członków danego związku wyznaniowego.

Do ustaleń na temat modelu stosunków państwo - związek wyznaniowy czynionych na podstawie ustaw wewnętrznych tych zrzeszeń należy podchodzić z rezerwą. Te dokumenty wprawdzie, co do zasady, oddają nauczanie doktrynalne lub są nim inspirowane, jednakże w przypadku ustaw wewnętrznych uchwalonych przed 1989 r. nie ma pewności, czy są one rzeczywiście w pełni endogenicznymi aktami prawnymi danego związku wyznaniowego. Ta niepewność jest spowodowana tym, że przed wejściem w życie liberalnej

I39 Por. M. Washofsky, Halakhah and Political Theory: A Study in Jewish Legal Response to Modernity, „Modern Judaism” 9 (Oct., 1989) No. 3, s. 289-310.

I40 Por. Ch. Jachter, Gray Matter. Exproring Contemporary Hallachic Challenges, vol. 3, Teanec 2008, s. 280 .

I4I Tłumaczenie na język angielski - ShulchanArach.com: Free English Translation of The Shulchan Aruch: Jewish Code of Law, http://www.shulchanarach.com (18.09.2015). 
ustawy o gwarancjach wolności sumienia i wyznania z 1989 r. władza państwowa przypisywała sobie kompetencje lub uprawnienia kontrolno-nadzorcze w stosunku do związków wyznaniowych. $Z$ racji ustawowego wymogu zatwierdzenia przez państwową władzę tych statutów wspomniane kompetencje i uprawnienia były nolens volens wpisywane w wewnętrzne akty normatywne.

Należy poczynić jeszcze ogólną uwagę - powiązania z państwem nie można wyczytać z oficjalnych nazw kościołów i innych związków wyznaniowych. Nazwy te zawierają wprawdzie określenia, takie jak: „Polski” (jak w przypadku Polskiego Autokefalicznego Kościoła Prawosławnego) czy „Rzeczypospolitej Polskiej” lub „w Rzeczypospolitej” (jak w przypadku pozostałych podmiotów znajdujących się w optyce tej pracy), jest to jednak raczej wskazanie na miejsce ich głównej działalności.

\subsubsection{Równouprawnienie kościołów i innych związków wyznaniowych}

Kolejną zasadą kształtującą relację pomiędzy państwem a kościołami i związkami religijnymi jest zasada ich równouprawnienia względem państwa i prawa państwowego.

\subsubsection{Perspektywa państwowa}

Dla kształtowania tych relacji ze strony państwa kluczowe znaczenie ma art. 25 ust. I Konstytucji RP, w którym ustrojodawca postanowił, że „Kościoły i inne związki wyznaniowe są równouprawnione" ${ }^{142}$. Przepis ten przede wszystkim wyraża zasadę, że nie ma w Polsce religii panującej, a tym samym żaden kościół czy związek wyznaniowy nie jest uprzywilejowany prawnie ${ }^{143}$. Nie ma także kościoła czy innego związku wyznaniowego, który zajmowałby naczelne stanowisko wśród równouprawnionych wyznañ ${ }^{144}$.

I42 Szeroko o tym pisze D. Dudek, Równouprawnienie kościotów i związków wyznaniowych na tle konstytucyjnych zasad prawa wyznaniowego, [w:] Prawo wyznaniowe $w$ systemie prawa polskiego..., dz. cyt., s. 199-225.

I43 Por. W. Skrzydło, Konstytucja Rzeczypospolitej Polskiej. Komentarz, dz. cyt., s. 36.

I44 Por. art. II4 Ustawy z dnia I7 marca I92I r. Konstytucja Rzeczypospolitej Polskiej (Dz.U. Nr 44, poz. 267 z późn. sprost.). 
$\mathrm{Z}$ tego przepisu nie można jednak wysnuć wniosku o absolutnym egalitaryzmie tych podmiotów. Jak stwierdził Trybunał Konstytucyjny w wyroku z dnia 7 czerwca 2004 r.: „Różnicowanie w prawie jest dopuszczalne, o ile jest usprawiedliwione" ${ }^{145}$. Chociaż - jak uznał Trybunał Konstytucyjny w wyroku z dnia I3 marca 2006 r. - w świetle zasady równości nie wolno tworzyć prawa różnicującego sytuację prawną podmiotów, których sytuacja faktyczna jest taka sama, to jednak równość tych podmiotów oznacza zarazem akceptację różnego traktowania przez prawo różnych podmiotów, z tym że różne traktowanie powinno być uzasadnione. „Sprawiedliwość wymaga, aby zróżnicowanie prawne podmiotów (ich kategorii) pozostawało w odpowiedniej relacji do różnic w ich sytuacji faktycznej jako adresatów danych norm prawnych" ${ }^{146}$. Podobne stanowisko zajął Trybunał Konstytucyjny w wyroku z dnia I4 grudnia 2009 r. ${ }^{147}$. W związku z tym, że Konstytucja RP w art. 53 ust. 4 odróżnia kościoły i inne związki wyznaniowe o uregulowanej sytuacji prawnej od pozostałych kościołów i innych związków wyznaniowych ${ }^{\mathrm{I} 48}$, ustrojodawca wprowadził zasadę daleko idącej indywidualizacji ustaw wyznaniowych i dostosowywania treści zawieranych umów, a w konsekwencji i ustanawianych ustaw do specyficznej sytuacji poszczególnych kościołów i innych związków wyznaniowych. W orzeczeniu tym Trybunał Konstytucyjny podał także, że ogólna zasada równości dopuszcza w pewnych sytuacjach różnicowanie podmiotów podobnych, jeżeli zostały spełnione trzy warunki. „Po pierwsze, wprowadzone przez prawodawcę różnicowania muszą być racjonalnie uzasadnione. Muszą mieć związek z celem i treścią przepisów, w których zawarta jest kontrolowana norma. Po drugie, waga interesu, któremu ma służyć różnicowanie podmiotów podobnych, musi pozostawać w odpowiedniej proporcji do wagi interesów, które zostaną naruszone w wyniku ich różnego traktowania. [...] Po trzecie, różnicowanie podmiotów podobnych musi znajdować podstawę w wartościach, zasadach lub normach konstytucyjnych. Różnicowanie kościołów i związków wyznaniowych, które nie znajduje odpowiedniej legitymizacji w wartościach, zasadach lub

I45 Wyrok Trybunału Konstytucyjnego z dnia 7 czerwca 2004 r., P 4/o3, Legalis $\mathrm{nr} 63693$.

I46 Wyrok Trybunału Konstytucyjnego z dnia I3 marca 2006 r., P 8/05, Legalis nr 72932.

I47 Wyrok Trybunału Konstytucyjnego z dnia I4 grudnia 2009 r., K 55/07, Legalis nr 180038 .

I48 Zob. L. Garlicki, Art. 25, [w:] Konstytucja Rzeczypospolitej Polskiej. Komentarz, red. L. Garlicki, t. 5, Warszawa 2007, s. II. 
normach konstytucyjnych, jest niedopuszczalne”. Rozumienie zasady równości pomiędzy kościołami i innymi związkami wyznaniowymi jako reguły absolutnej prowadziłoby do zredukowania uprawnień kościołów i innych związków wyznaniowych do uprawnień jednego, mającego najmniejszą liczbę wiernych, a w konsekwencji zredukowania uprawnień wolnościowych obywateli ${ }^{149}$.

W tym kontekście należy umieścić fakt, że ze względu na specyfikę Kościoła katolickiego, polegającą na tym, że w prawie międzynarodowym Stolica Apostolska ma podmiotowość prawną, stosunki między Rzecząpospolitą Polską a Kościołem katolickim określa umowa międzynarodowa zawarta ze Stolicą Apostolska, czyli Konkordat oraz inne ustawy (art. 25 ust. 4 Konstytucji RP) ${ }^{150}$. Należy odnotować Wyrok Trybunału Konstytucyjnego z dnia 2 grudnia 2009 r. ${ }^{151}$. Organ ten zwrócił uwagę, iż „równouprawnienie kościołów i związków wyznaniowych, o którym mowa w art. 25 ust. I Konstytucji RP, należy interpretować w kontekście przepisów ust. 4 i 5 tegoż artykułu”. Szczególnie należy wziąć po uwagę to, że art. 25 ust. 4 stanowi lex specialis wobec artykułu 25 ust. I Konstytucji RP. Ta szczególna pozycja instytucjonalna Kościoła katolickiego w systemie prawnym państwa polskiego, odzwierciedlająca jego dominującą pozycję w strukturze wyznaniowej Polaków ${ }^{152}-$ zdaniem Trybunału Konstytucyjnego - „nie może w żaden sposób dotykać równych praw każdego, wynikających z wolności wszystkich religii i wyznań” ${ }^{\text {Is3. }}$

\subsubsection{Perspektywa religijna}

W warunkach ustrojowych Polski żaden z kościołów lub innych związków wyznaniowych nie domaga się specjalnego, czyli uprzywilejowanego traktowania.

I49 Por. J. Krukowski, Konstytucyjny model stosunków między państwem a Kościotem w III Rzeczypospolitej, dz. cyt., s. 88.

I50 Umowa konkordatowa nie może naruszać zasady równości wszystkich wyznań wobec państwa prawa. Zob. J. Krukowski, Podstawowe zagadnienia prawa konkordatowego, „Studia Prawnicze” (1995) z. I-4, s. I05-I34.

I5I Wyrok Trybunału Konstytucyjnego z dnia 2 grudnia 2009 r., U Io/07, Legalis nr 178953.

I52 Według danych z Głównego Urzędu Statystycznego 95,5\% ludności Polski stanowią katolicy. Zob. Główny Urząd Statystyczny, Wyznania religijne, stowarzyszenia narodowościowe i etniczne w Polsce 2009-20II, Warszawa 2013, s. 36.

I53 Wyrok Trybunału Konstytucyjnego z dnia 2 grudnia 2009 r., U Io/o7, Legalis nr 178953 . 
Kościół katolicki na Soborze Watykańskim II w deklaracji Dignitatis humanae odrzucił zasadę podwójnych standardów dla członków swojego Kościoła i tych, którzy do niego nie należą. Ta dawna polityka względem władzy państwowej może być sformułowana w dwóch punktach. Po pierwsze, Kościół domagał się wolności religijnej i specjalnej ochrony dla katolików wtedy, gdy stanowili oni mniejszość w społeczeństwie oraz przywilejów dla nich - nieraz kosztem innych grup religijnych - wtedy, gdy stanowili większą część społeczeństwa. W tym wymiarze Dignitatis humanae otwarła drogę do nowego zaufania w relacjach ekumenicznych, a nawet otwarła drogę do dialogu międzyreligijnego ${ }^{154}$.

\subsubsection{Współpraca państwa z kościołami oraz innymi związkami wyznaniowymi}

Poprzez formę relacji rozumieć należy kształt, jaki w praktyce zostaje nadany stosunkom pomiędzy państwem a kościołami lub innymi związkami wyznaniowymi. Relacje te przybierały różnorodne formy ${ }^{155}$.

Wydaje się, że w polskich warunkach prawno-kulturowych optymalną formą relacji wymienionych podmiotów jest współpraca. Podstawą współpracy jest przynależność obywateli i wiernych do państwa i wspólnoty religijnej. W obu, jakże odmiennych strukturach, podmiotem praw i obowiązków jest ten sam człowiek. Te dwie przynależności są mocno ze sobą powiązane. Wierny i jednocześnie obywatel jest zaangażowany w życie obydwu społeczności.

Trzeba w tym miejscu podkreślić, że Kościół katolicki nie tylko nakazuje wiernym przestrzeganie swojego prawa (kan. $209 \$ 2 \mathrm{KPK}$ ), lecz w swoim nauczaniu wyraża także troskę o właściwe realizowanie prawa państwowego przez wiernych. Sobór Watykański II upominał katolików, aby przykładali się do wiernego wypełniania swych obowiązków ziemskich, kierując się w tym duchem Ewangelii (LG 43). Podobnie, choć w ściśle określonym zakresie, nakłada taki obowiązek na ewangelików Pragmatyka Służbowa Kościoła Ewangelicko-Augsburskiego (zob. $\$$ I59 ust. 3, $\$ 205$ ust. $2, \$ 234, \$ 246$ ust. I Ps).

I54 Por. J. C. Murray, Religious freedom, [w:] Documents of Vatican II, in a New and Definitive Translation, with Commentaries and Notes by Catholic Protestant, and Orthodox Authorities, gen. ed. W. M. Abbott, New York 1966, s. 673.

I55 Zob. np. H. Misztal, Polskie prawo wyznaniowe, t. I: Zagadnienia wstępne. Rys historyczny, Lublin 1996, s. 6I-73; W. Góralski, Wstęp do prawa wyznaniowego, Płock 2003, s. 9-25. 
Celem zaś współpracy, o której mowa jest „dobro wspólne”. Termin ten w katolickich źródłach doktrynalnych wyrażany jako bonum commune oznacza sumę warunków życia społecznego, które pozwalają pełniej i szybciej osiągnąć doskonałość zarówno w wymiarze wspólnotowym, jak i indywidualnym. Nie jest to tylko prosta suma dóbr indywidualnych, lecz także nowa jakość w wymiarze wspólnoty (por. LG 56). Zgodnie bowiem ze społeczną naturą człowieka dobro każdego pozostaje w sposób konieczny w relacji z dobrem wspólnym (кKK 1905).

W Konstytucji RP termin ten zastosowano kilka razy - preambuła, art. I, at. 25 ust. 3, art. 82. Genezy określenia dobra wspólnego w debatach nad projektem Konstytucji RP należy poszukiwać w nauczaniu Kościoła katolickie$\mathrm{go}^{156}$. To jednak nie oznacza nadawania pojęciu „dobro wspólne” treści konfesyjnej ani nie stanowi zaprzeczenia świeckości państwa ${ }^{157}$. Z pojęcia tego wynika raczej, że Rzeczpospolita Polska jest dobrem wspólnym wszystkich obywateli, a także, że w razie potrzeby ochrony dobra ogólnego to dobro jest stawiane ponad dobro indywidualne czy partykularny interes grupowy ${ }^{158}$. Oczywiście Polska rozumiana jako dobro wspólne winna troszczyć się zarówno o prawa większości, jak i o zabezpieczenie praw mniejszości wchodzących w jej skład ${ }^{159}$.

Z zasadą dobra wspólnego w ścisłym związu pozostaje zasada bezstronności władz publicznych w sprawach przekonań religijnych, światopoglądowych i filozoficznych (art. 25 ust. 2 Konstytucji RP). Polska jako dobro wspólne wszystkich obywateli nie zajmuje stanowiska w sprawach przekonań, ale zapewnia obywatelom oraz ich przekonaniom równe traktowanie.

Współpraca może oczywiście odbywać się na tych polach, które cieszą się zainteresowaniem zarówno państwa, jak i związków wyznaniowych. Kościół i państwo, zdaniem papieża Jana Pawła II, mają tak działać, aby ożywiać duchem chrześcijańskim doczesną rzeczywistość, służąc osobie i społeczeństwu i w ten sposób służyć wzrastaniu wspólnego dobra ${ }^{160}$. Wydaje się, że szczególne miejsce

I56 Por. M. Piechowiak, Dobro wspólne jako fundament polskiego porządku konstytucyjnego, Warszawa 2012, s. I2I.

I57 Por. B. Banaszak, Konstytucja Rzeczypospolitej Polskiej. Komentarz, dz. cyt., art. I/I.

I58 Por. Wyrok Trybunału Konstytucyjnego z dnia 30 stycznia 200 I r., K I7/oo, Legalis nr 49436.

I59 Por. W. Skrzydło, Konstytucja Rzeczypospolitej Polskiej. Komentarz, dz. cyt., s. I5.

I60 Por. Joannes Paulus Pp. II, Adhortatio apostolica Christifideles laici de vocatione et missione Laicorum in Ecclesia et in mundo, 30.12.1988, AAS 8I (I989), nr 23, s. $429-433$. 
w tej współpracy może zajmować dobro indywidualne, dobro małżeństwa i rodziny, dobro narodu oraz dobro innych grup społecznych ${ }^{161}$.

Słusznie twierdzi się, że zasada współpracy państwa z kościołami lub innymi związkami religijnymi nie ma charakteru obowiązku w znaczeniu normy programowej. Stanowi raczej swoisty imperatyw dla organów władz publicznych. Współpraca ta powinna być zatem realizowana w miarę potrzeb i możliwości, których istnienie i zakres zależy od uznania stron. Zasada ta nie może więc być normatywną podstawą do roszczeń skierowanych do władz publicznych przez kościoły lub związki wyznaniowe. Takie rozumienie zasady współpracy pozwala na wniosek, że z art. 25 ust. 3 Konstytucji RP nie wynika wprost obowiązek kooperacji. Również określenie zakresu współpracy jest uznaniowo pozostawione stronie państwowej lub samorządowej ${ }^{162}$. Także art. I Konkordatu nie zobowiązuje stron do takiego współdziałania.

Jednakże poszczególne ustawy pośrednio nakazują taką współpracę. Przykładowo, zgodnie z ustawą o pomocy społecznej organy administracji samorządowej współpracują, na zasadzie partnerstwa, z organizacjami społecznymi i pozarządowymi, Kościołem katolickim, innymi kościołami, związkami wyznaniowymi oraz osobami fizycznymi i prawnymi (art. 2 ust. 2 ustawy o pomocy społecznej $\left.{ }^{163}\right)$.

Także i inne regulacje w zakresie pomocy społecznej i profilaktyki społecznej (art. 2I pkt I u.p.s.) nakazują władzom samorządu województwa opracowanie, aktualizowanie i realizację strategii wojewódzkiej w zakresie polityki społecznej. Ta strategia jest integralną częścią strategii rozwoju województwa (art. II ustawy o samorządzie województwa ${ }^{164}$ ). Zgodnie $\mathrm{z}$ art. I2 ust. I pkt 4 ustawy o samorządzie województwa obowiązek współpracy w zakresie formułowa-

I6I Por. P. Sobczyk, Kościót a wspólnoty polityczne, Warszawa 2005, s. 2I2-217; J. Krukowski, Kościót i państwo. Podstawy relacji prawnych, dz. cyt., s. I27-133; zob. M. Piechowiak, Dobro wspólne jako fundament polskiego porządku konstytucyjnego, dz. cyt., s. 233-235.

I62 Por. M. Olszówka, Przenikanie się prawa państwowego i prawa wewnętrznego związków religijnych $w$ świetle art. 25 ust. 3 konstytucji RP, [w:] Prawo państwowe a prawo wewnętrzne związów wyznaniowych. Pamiętnik VII Zjazdu Katedr i Wyktadowców Prawa Wyznaniowego, Gniezno II-I2 września 20I0, red. K. Krasowski i inni, Poznań 20IO, s. I2O-I2I.

I63 Ustawa z dnia I2 marca 2004 r. o pomocy społecznej (tekst jedn. Dz.U. z 2016 r. poz. 930 z późn. zm.) [dalej: u.p.s.].

I64 Ustawa z dnia 5 czerwca 1998 r. o samorządzie województwa (tekst jedn. Dz.U. z 2016 r. poz. 486). 
nia strategii rozwoju województwa i realizacji polityki jego rozwoju istnieje w szczególności w odniesieniu do organizacji pozarządowych oraz podmiotów wymienionych w art. 3 ust. 3 Ustawy z dnia 24 kwietnia 2003 r. o działalności pożytku publicznego i o wolontariacie ${ }^{165}$. Należą do nich m.in. osoby prawne i jednostki organizacyjne działające na podstawie przepisów Ustawy z dnia I7 maja 1989 r. o stosunku Państwa do Kościoła Katolickiego w Rzeczypospolitej Polskiej, a więc m.in. diecezje, parafie (art. 7 u.s.p.k.k.), czy organizacje kościelne i organizacje katolickie (art. 34 i 35 u.s.p.k.k.), jeżeli ich cele statutowe obejmują prowadzenie działalności pożytku publicznego. Współpraca w przedmiotowej materii ma prawne podwaliny także w ustawie o pomocy społecznej na poziomie powiatu i gminy.

Ustawa z dnia 26 października 1982 r. o wychowaniu w trzeźwości i przeciwdziałaniu alkoholizmowi ${ }^{166}$ zawiera sformułowany expressis verbis nakaz skierowany do organów administracji rządowej i jednostek samorządu terytorialnego dotyczący podejmowania działań zmierzających do realizacji celów tej ustawy - czyli zasadniczo do ograniczania spożycia napojów alkoholowych i w tym zakresie do współdziałania z Kościołem katolickim (art. I ust. 3 u.w.t.). Z kolei zgodnie z Ustawą dnia 29 lipca 2005 r. o przeciwdziałaniu narkomanii ${ }^{167}$ w realizacji celów tej ustawy mogą uczestniczyć organizacje pozarządowe i inne podmioty, których działalność statutowa obejmuje zadania należące do sfery zadań publicznych w zakresie ochrony i promocji zdrowia, pomocy społecznej, działalności charytatywnej, nauki, edukacji, oświaty i wychowania, kultury fizycznej, porządku i bezpieczeństwa publicznego lub przeciwdziałania patologiom społecznym, promocji i organizacji wolontariatu (art. 5 ust. 3 u.p.n.).

Oczywiście wymienione akty normatywne nie nakładają na kościoły lub związki wyznaniowe nakazu współpracy. Normę dotyczącą współpracy z państwem może jedynie nałożyć ich własny organ prawodawczy. Prawo wewnętrzne może nakazywać lub umożliwiać współpracę osób prawnych religijnych zrzeszeń z władzami rządowymi lub samorządowymi, z ośrodkami pomocy społecznej czy innymi organizacjami.

I65 Tekst jedn. Dz.U. z 2016 r. poz. I8I7.

I66 Tekst jedn. Dz.U. z 2016 r. poz. 487 z późn. zm. [dalej: u.w.t.].

I67 Tekst jedn. Dz.U. z 2016 r. poz. 224 z późn. zm. [dalej: u.p.n.]. 


\subsection{Formy obecności związków wyznaniowych w polskim porządku prawnym}

W polskim porządku prawnym związki wyznaniowe istnieją w różnych prawnych formach. Niestety ani istnienie, ani rodzaj tych form nie są jasno opisane w obowiązującym prawie. Inaczej było w Ustawie z dnia I7 marca I92I r. Konstytucja Rzeczypospolitej Polskiej ${ }^{\text {I68 }}$, gdzie w art. II5 i II6 ustanowiono, że stosunek państwa do kościołów mniejszościowych (czyli wszystkich poza Kościołem katolickim) i wyznań „będzie ustalany w drodze ustawowej po porozumieniu się z ich prawnymi reprezentacjami” (art. II5) oraz że „uznanie nowego lub dotąd prawnie nieuznanego wyznania nie będzie odmówione związkom religijnym, których urządzenia, nauka i ustrój nie są przeciwne porządkowi publicznemu ani obyczajności publicznej” (art. II6).

\subsubsection{Indywidualna regulacja ustawowa}

\subsubsection{Obowiązujące ustawy}

W optyce rozważań znajdą się kościoły i inne związki wyznaniowe o uregulowanym przez ustawy stosunku do Rzeczypospolitej Polskiej. Do tego zbioru należą ${ }^{169}$ :

I. Kościół katolicki ${ }^{170}$,

2. Polski Autokefaliczny Kościół Prawosławny ${ }^{171}$,

3. Kościół Ewangelicko-Reformowany w Rzeczypospolitej ${ }^{172}$,

4. Kościół Ewangelicko-Augsburski w Rzeczypospolitej Polskiej ${ }^{173}$,

I68 Dz.U. Nr 44, poz. 267 z późn. zm. i sprost.

I69 Kolejność zgodnie z wykazem kościołów i związków wyznaniowych działających na podstawie odrębnych ustaw ze strony https://mac.gov.pl/files/wykaz_kosciolow_ustawowych.pdf (I2.07.2015).

I70 Zob. Ustawa z dnia I7 maja I989 r. o stosunku Państwa do Kościoła Katolickiego w Rzeczypospolitej Polskiej (tekst jedn. Dz.U. z 2013 r. poz. II69 z późn. zm.).

I7I Zob. Ustawa z dnia 4 lipca I99i r. o stosunku Państwa do Polskiego Autokefalicznego Kościoła Prawosławnego (tekst jedn. Dz.U. z 20I4 r. poz. I726).

I72 Zob. Ustawa z dnia I3 maja I994 r. o stosunku Państwa do Kościoła Ewangelicko-Reformowanego w Rzeczypospolitej Polskiej (tekst jedn. Dz.U. z 20I5 r. poz. 483).

I73 Zob. Ustawa z dnia I3 maja I994 r. o stosunku Państwa do Kościoła Ewangelicko-Augsburskiego w Rzeczypospolitej Polskiej (tekst jedn. Dz.U. z 20I5 r. poz. 43). 
5. Kościół Ewangelicko-Metodystyczny w Rzeczypospolitej Polskiej ${ }^{174}$,

6. Kościół Starokatolicki Mariawitów w Rzeczypospolitej Polskiej ${ }^{175}$,

7. Kościół Katolicki Mariawitów w Rzeczypospolitej Polskiej ${ }^{176}$,

8. Wschodni Kościół Staroobrzędowy nieposiadający hierarchii duchownej w Rzeczypospolitej Polskiej ${ }^{177}$,

9. Muzułmański Związek Religijny w Rzeczypospolitej Polskiej ${ }^{178}$,

Io. Karaimski Związek Religijny w Rzeczypospolitej Polskiej ${ }^{179}$,

II. Kościół Chrześcijan Baptystów w Rzeczypospolitej Polskiej ${ }^{180}$,

I2. Kościół Polskokatolicki w Rzeczypospolitej Polskiej ${ }^{18 \mathrm{I}}$,

W dniu I6 października 2015 r. zostało podpisane porozumienie podsumowujące prace Zespołu Redakcyjnego powołanego w celu opracowania projektu Umowy między Radą Ministrów i Kościołem Ewangelicko-Augsburskim w RP oraz załącznika do tegoż porozumienia w postaci projektu ustawy o zmianie ustawy z dnia I3 maja I994 r. o stosunku Państwa do Kościoła Ewangelicko-Augsburskiego w RP.

I74 Zob. Ustawa z dnia 30 czerwca I995 r. o stosunku Państwa do Kościoła Ewangelicko-Metodystycznego w Rzeczypospolitej Polskiej (tekst jedn. Dz.U. z 2014 r. poz. I7I2).

I75 Zob. Ustawa z dnia 20 lutego 1997 r. o stosunku Państwa do Kościoła Starokatolickiego Mariawitów w Rzeczypospolitej Polskiej (tekst jedn. Dz.U. z 20I5 r. poz. I4). I76 Zob. Ustawa z dnia 20 lutego I997 r. o stosunku Państwa do Kościoła Katolickiego Mariawitów w Rzeczypospolitej Polskiej (tekst jedn. Dz.U. z 20I5 r. poz. 44).

I77 Zob. Rozporządzenie Prezydenta Rzeczypospolitej z dnia 22 marca I928 r. o stosunku Państwa do Wschodniego Kościoła Staroobrzędowego, nie posiadającego hierarchji duchownej (Dz.U. Nr 38, poz. 363 z późn. zm.).

I78 Zob. Ustawa z dnia 2I kwietnia 1936 r. o stosunku Państwa do Muzułmańskiego Związku Religijnego w Rzeczypospolitej Polskiej (Dz.U. Nr 30, poz. 240 z późn. zm.). Można dodać, że w okresie od lipca 2008 r. do listopada 2010 r. miały miejsce posiedzenia Zespołu Roboczego do prac nad projektem umowy oraz ustawy, która miała zastąpić obecnie obowiązującą Ustawę z dnia 2I kwietnia 1936 r. o stosunku Państwa do Muzułmańskiego Związku Religijnego w Rzeczypospolitej Polskiej (Dz.U. $\mathrm{Nr}$ 30, poz. 240, z późn. zm.). W dniu 30 listopada 20I4 r. Xx Nadzwyczajny Kongres Muzułmańskiego Związku Religijnego w RP podjął decyzję o konieczności zmiany wymienionej ustawy. Pismem z dnia 7 stycznia 2015 r. poinformował o swoim stanowisku Ministerstwo Administracji i Cyfryzacji, przekazując projekt nowelizacji. W dniu 7 sierpnia 2015 r. Ministerstwo Administracji i Cyfryzacji przekazało Muzułmańskiemu Związkowi Religijnemu propozycję projektu ustawy o zmianie wyżej wymienionej ustawy z dnia 2I kwietnia $1936 \mathrm{r}$.

I79 Zob. Ustawa z dnia 2I kwietnia 1936 r. o stosunku Państwa do Karaimskiego Związku Religijnego w Rzeczypospolitej Polskiej (Dz.U. Nr 30, poz. 24I z późn. zm.).

I80 Zob. Ustawa z dnia 30 czerwca I995 r. o stosunku Państwa do Kościoła Chrześcijan Baptystów w Rzeczypospolitej Polskiej (tekst jedn. Dz.U. z 20I5 r. poz. I69).

I8I Zob. Ustawa z dnia 30 czerwca 1995 o stosunku Państwa do Kościoła Polskokatolickiego w Rzeczypospolitej Polskiej (tekst jedn. Dz.U. z 2014 r. poz. 1599). 
I3. Kościół Adwentystów Dnia Siódmego w Rzeczypospolitej Polskiej ${ }^{182}$,

I4. gminy wyznaniowe żydowskie tworzące Związek Gmin Wyznaniowych Żydowskich w Rzeczypospolitej Polskiej ${ }^{183}$,

I5. Kościół Zielonoświątkowy w Rzeczypospolitej Polskiej ${ }^{184}$.

Jako pierwsza została uchwalona ustawa o stosunku państwa do Kościoła katolickiego. Akt ten oraz ustawa o gwarancjach wolności sumienia i wyznania uważane są za lodołamacze przezwyciężające ograniczenia w dziedzinie wolności religijnej ${ }^{185}$. Istotną ustawą, o której trzeba wspomnieć, była także ustawa o ubezpieczeniu społecznym duchownych z 1989 r. $^{186}$. Za przedstawicielem doktryny trzeba stwierdzić, że te trzy akty normatywne odrzucają zróżnicowany przedmiotowo katalog ograniczeń indywidualnej i zbiorowej wolności sumienia i wyznania, przyjmując wolnościową wykładnię funkcji religijnych wypełnianych przez kościoły i związki wyznaniowe. Wprowadzają one także nowe gwarancje wolności sumienia i wyznania. Ustawy te stwarzają ponadto korzystniejsze od ogólnie obowiązujących rozwiązania prawne dla działalności gospodarczej kościołów i innych związków wyznaniowych. Tym samym starają się naprawić niesprawiedliwości natury majątkowej wyrządzone w przeszłości Kościołowi katolickiemu i innym związkom wyznaniowym ${ }^{187}$.

W tym miejscu można postawić pytanie, dlaczego jedynie Is kościołów i innych związków wyznaniowych ma poświęcone im ustawy. Pewnym wytłumaczeniem takiego legislacyjnego status quo może być tradycja prawna. Kościół katolicki miał sytuację uregulowaną przez Konkordat z 1925 r. $^{188}$, natomiast

I82 Zob. Ustawa z dnia 30 czerwca 1995 r. o stosunku Państwa do Kościoła Adwentystów Dnia Siódmego w Rzeczypospolitej Polskiej (tekst jedn. Dz.U. z 2014 r. poz. I889).

I83 Zob. Ustawa z dnia 20 lutego 1997 r. o stosunku Państwa do gmin wyznaniowych żydowskich w Rzeczypospolitej Polskiej (tekst jedn. Dz.U. z 20I4 r. poz. 1798).

I84 Zob. Ustawa z dnia 20 lutego 1997 r. o stosunku Państwa do Kościoła Zielonoświątkowego w Rzeczypospolitej Polskiej (tekst jedn. Dz.U. z 20I5 r. poz. I3).

I85 Por. E. Goryczko, Autonomia i samorządność związków wyznaniowych w Polsce Ludowej, Tarnów 2005, s. 227. Na s. 238-248 autorka pisze na temat genezy tych ustaw i ich przygotowania.

I86 Por. Ustawa z dnia I3 października I998 r. o systemie ubezpieczeń społecznych (tekst jedn. Dz.U. z 2016 r. poz. 963 z późn. zm.).

I87 Por. M. Pietrzak, Model stosunków Państwo-Kościót w świetle ustaw wyznaniowych z I7 maja I989 roku, „Kościół i Prawo” I2 (I944), s. 9-24.

I88 Konkordat pomiędzy Stolicą Apostolską a Rzecząpospolitą Polską, podpisany w Rzymie dnia io lutego 1925 r. (Dz.U. z 1925 r. Nr 72, poz. 501 i 502). Konkordat ten 
niektóre z kościołów i innych związków wyznaniowych akty normatywne regulujące ich status. Niektóre z nich były ustanowione w czasie II Rzeczypospolitej przez polskie organy władzy ustawodawczej ${ }^{189}$. Oto należące do tej grupy kościoły i ich akty normatywne:

I. Wschodni Kościół Staroobrzędowy, nie posiadający hierarchji duchownej - Rozporządzenie Prezydenta Rzeczypospolitej z dnia 22 marca I928 r. o stosunku Państwa do Wschodniego Kościoła Staroobrzędowego, nie posiadającego hierarchji duchownej ${ }^{190}$;

2. Muzułmański Związek Religijny - Ustawa z dnia 2I kwietnia I936 r. o stosunku Państwa do Muzułmańskiego Związku Religijnego w Rzeczypospolitej Polskiej ${ }^{191}$;

przestał obowiązywać jako umowa międzynarodowa w wyniku uchwały Rady Ministrów Tymczasowego Rządu Jedności Narodowej z dnia I2 września I945 r. stanowiącej: „Konkordat zawarty między Stolicą Apostolską i Rzeczpospolitą Polską przestał obowiązywać” („Głos Ludu” z dnia I4.09.1945 r.), cytowane przez Wyrok Sądu Najwyższego - Izba Cywilna z dnia 25 lutego 2015 r., IV CSK 3I2/I4, Legalis nr I2I3092.

Jednakże według Orzeczenia Sądu Apelacyjnego w Poznaniu z dnia I8 sierpnia 1946 r., I Cz 83/46 za K. Skubiszewski, Konkordat z Io lutego I925 r. Zagadnienia prawnomiędzynarodowe, [w:] Kościót w II Rzeczypospolitej, red. Z. Zieliński, S. Wilk, Lublin 1980, s. 46 - należy oddzielić skutki obowiązywania Konkordatu na płaszczyźnie międzynarodowej (ratyfikacja) od skutku obowiązywania umowy w porządku krajowym (publikacja w „Dzienniku Ustaw Rzeczypospolitej Polskiej”). Z tego względu sąd ten uznał, że chociaż Konkordat, na skutek powołanej Uchwały Rady Ministrów z dnia I2 września 1945 r. przestał wiązać Polskę ze Stolicą Apostolską, jako traktat międzynarodowy, to jednak stanowił w dalszym ciągu źródło prawa wewnętrznego, gdyż Ustawa z dnia 23 kwietnia 1925 r. o zatwierdzeniu układu ze Stolicą Apostolską, określającego stosunek Państwa do Kościoła Rzymsko-Katolickiego (Dz.U. Nr 47, poz. 324) nie została uchylona, a Uchwała Rady Ministrów z dnia I2 września 1945 r. nie została opublikowana w zbiorze urzędowym. Na ten wyrok powołuje się Sąd Najwyższy - Izba Cywilna z dnia 25 lutego 2015 r. IV CSK 312/I4, Legalis nr I213092. Zob. także: A. Rzepecki, Problematyka wygaśnięcia Konkordatu zawartego między Rzeczpospolita Polska a Stolica Apostolska w dniu Io lutego Ig25 r., "Studia Erasmiana Wratislaviensia” (2011) z. 5, s. 285-304; T. Pawluk, Problem wygaśnięcia konkordatu polskiego z I925 r., „Prawo Kanoniczne” 29 (I986) nr I-2, s. I34-135; A. Mezglewski, Spór o wygaśnięcie konkordatu polskiego z I925 roku, „Roczniki Nauk Prawnych" 8 (1988), s. 325-240.

I89 O założeniach polityki wyznaniowej i trybie rejestracji w okresie II Rzeczypospolitej Polskiej piszą W. Wysoczański, M. Pietrzak, Prawo Kościotów i związków wyznaniowych nierzymskokatolickich $w$ Polsce, dz. cyt., s. I4-I6.

I90 Dz.U. Nr 38, poz. 363 z późn. zm.

I9I Dz.U. Nr 30, poz. 240 z późn. zm. 
3. Karaimski Związek Religijny - Ustawa z dnia 2I kwietnia 1936 r. o stosunku Państwa do Karaimskiego Związku Religijnego w Rzeczypospolitej Polskiej ${ }^{192}$;

4. Polski Autokefaliczny Kościół Prawosławny -

a. Tymczasowe przepisy o stosunku Rządu do Kościoła Prawosławnego w Polsce z dnia 30 stycznia 1922 r. wydane przez Ministra Wyznań Religijnych i Oświecenia Publicznego ${ }^{193}$,

b. Dekret Prezydenta Rzeczypospolitej Polskiej z dnia I8 listopada I938 r. o stosunku Państwa do Polskiego Autokefalicznego Kościoła Prawosławnego ${ }^{194}$,

c. Rozporządzenie Rady Ministrów z dnia Io grudnia 1938 r. o uznaniu Statutu Wewnętrznego Polskiego Autokefalicznego Kościoła Prawosławnego ${ }^{\text {195 }}$,

d. Zarządzenie Ministra Wyznań Religijnych i Oświecenia Publicznego z dnia 6 maja 1939 r. zatwierdzające Statut Konsystorzy Diecezjalnych Polskiego Autokefalicznego Kościoła Prawosławnego ${ }^{\mathrm{I9}}$,

e. Ustawa z dnia 23 czerwca 1939 r. o uregulowaniu stanu prawnego majątków Kościoła Prawosławnego ${ }^{197}$;

5. Kościół Ewangelicko-Augsburski - Dekret Prezydenta Rzeczypospolitej z dnia 25 listopada 1936 r. o stosunku Państwa do Kościoła EwangelickoAugsburskiego w Rzeczypospolitej Polskiej ${ }^{198}$;

6. gminy żydowskie -

a. Dekret Naczelnika Państwa z dnia 7 lutego I9I9 r. o zmianach w organizacji gmin wyznaniowych żydowskich na terenie byłego Królestwa Kongresowego ${ }^{199}$,

b. Rozporządzenie Prezydenta Rzeczypospolitej z dnia I4 października I927 r. o uporządkowaniu stanu prawnego w organizacji gmin wyznaniowych żydowskich na obszarze Rzeczypospolitej Polskiej z wyjątkiem województwa śląskiego ${ }^{200}$.

192 Dz.U. Nr 30, poz. 24I z późn. zm.

193 M.P. Nr 38, poz. 20.

194 Dz.U. Nr 88, poz. 597 z późn. zm.

$195 \mathrm{Dz} . \mathrm{U} . \mathrm{Nr}$ 103, poz. 679.

I96 M.P. Nr i36, poz. 319.

197 Dz.U. Nr 57, poz. 370.

198 Dz.U. Nr 88, poz. 6I3 z późn. zm.

I99 „Dziennik Praw Państwa Polskiego” z I919 Nr I4, poz. I75.

200 Tekst jedn. Dz.U. z 1928 r. Nr 52, poz. 500 z późn. zm. (o wcześniejszych nazwach tego aktu normatywnego i zasięgu obwiązywania zob. A. Czohara, T. J. Zieliński, 
Zasadniczo akty te zostały nominalnie przejęte przez Polską Rzeczpospolitą Ludową. Dokonano w nich jedynie zmian dotyczących zawierania małżeństw ${ }^{201}$ i wyznaniowej rejestracji aktów stanu cywilnego ${ }^{202}$.

Nota bene, trzy pierwsze z wymienionych aktów normatywnych obowiązują do dziś. Trzeba odnotować, że istnieją głosy w doktrynie prawniczej, które podważają to stwierdzenie. Ich wyraziciele uważają, że skoro te akty normatywne nie miały swoich nowszych wersji po 1989 r., to popadły w całości lub w części w desuetudo ${ }^{203}$. Przykładowo, niektórzy autorzy, dokonując wykładni systemowej ustawy o stosunku do Muzułmańskiego Związku Wyznaniowego, utrzymują, że można domniemywać, iż z chwilą wejścia w życie w 1997 r. Konstytucji RP utraciły moc obowiązującą te przepisy ustawy, które są niezgodne z przepisami dotyczącymi wolności religijnej i swobody działalności kościołów i innych związków wyznaniowych ${ }^{204}$. Jednakże w obecnych warunkach prawnych, aby uznać, że dany przepis przestał obowiązywać, musi albo zostać derogowany przez ustawodawcę, albo musi zostać orzeczona wyrokiem Trybunału Konstytucyjnego jego niezgodność z Konstytucją i utrata mocy obowiązującej (art. I88 pkt I Konstytucji RP). Żadne z tych zdarzeń nie miało miejsca. Biorąc także pod uwagę ciągłość prawną państwa polskiego, zważywszy na pozytywistyczną koncepcję prawa w nim obowiązującego oraz na fundamentalne, co do

Ustawa o stosunku państwa do gmin wyznaniowych żydowskich $w$ Polsce. Komentarz, Warszawa 20I2, s. 269, przyp. 474). Na terenie Śląska regulacją dla gmin żydowskich była ustawa - Gesetz über die Verhältnisse der Juden. Von 4. Juli I875 (Ustawa z dnia 23 lipca I847 r. o związkach Żydów), „Gesetz-Sammlung für die Königlichen Preussischen Staaten” (Zbiór praw dla Państw Królestwa Pruskiego), Berlin I847, Nr. 30, Bon Nr. 287I, s. 263-278; natomiast na terenie Śląska Cieszyńskiego - Ustawa z dnia 2I marca I890 r. o urządzeniu stosunków prawnych zewnętrznych społeczności religii izraelickiej („Dziennik Ustaw Państwa dla Królestw i Krajów w Radzie Państwa Reprezentowanych" z I890 r., cz. I8, Nr 57, s. I09-II3).

201 Dekret z dnia 25 września 1945 r. Przepisy wprowadzające prawo małżeńskie (Dz.U. Nr 48, poz. 27I).

202 Dekret z dnia 25 września 1945 r. Przepisy wprowadzające prawo o aktach stanu cywilnego (Dz.U. Nr 48, poz. 273).

203 Zob. E. Goryczko, Autonomia i samorzadność związków wyznaniowych w Polsce Ludowej, Tarnów 2005, s. 64; odmienny pogląd w zakresie ustawy o MzR prezentuje zob. J. Sobczak, Potożenie prawne polskich wyznawców islamu, [w:] Islam a świat, red. R. Bräcker, S. Kitab, Toruń 2003, s. 207, nie podając jednak żadnych argumentów na poparcie tego stanowiska.

204 P. Borecki, Status prawny muzutmanów we wspótczesnej Polsce (3), „Przegląd Tatarski” (20II) nr 4, s. I8. 
zasady, tetyczne uzasadnienie norm w polskim systemie prawnym, pogląd o desuetudo tych aktów normatywnych jest błędny.

Trzeba się zgodzić z poglądem, że wiele przepisów aktów normatywnych, o których mowa, już prima facie nie wytrzymuje krytyki pod względem konstytucjonalności. Ma to miejsce w przypadku art. I ustawy dotyczącej muzułmanów stanowiącego, iż ogół wyznawców islamu na obszarze Polski tworzy Muzułmański Związek Religijny. Tym samym nadaje się związkowi charakter korporacji przymusowej. Jest to niezgodne z konstytucyjną zasadą wolności religii (art. 53 ust. 2 Konstytucji RP) w związku z wolnością zrzeszania się (art. 58 ust. I Konstytucji RP).

W ramach funkcjonalnych dyrektyw wykładni prawa można stwierdzić, iż niektóre z przepisów rzeczywiście popadły w desuetudo i przestały obowiązywać. Ma to jednak zastosowanie wyłącznie wówczas, gdy na skutek zmiany stosunków faktycznych stały się te przepisy niestosowalne. Bez wątpienia ma to miejsce w przypadku przepisów ustawy określających to, że siedzibą hachana jest Wilno (art. 3 ust. 2 u.s.p.k.z.r.; por. art. 4 ust. 2 i art. Io ust. 3, por. art. I2 ust. I u.s.p.m.z.r.). Sumując, te akty normatywne obowiązują właściwie w całym swym brzmieniu.

Należy odnotować, że istnieją także takie głosy w doktrynie prawniczej, które domagają się jak najszybszego wyeliminowania omawianych aktów normatywnych z systemu prawnego Polski. Argumentem za takim posunięciem jest to, że ich obowiązywanie „koliduje z zasadą zaufania obywateli do państwa, nie służy odpowiedniemu rozwojowi wspólnot konfesyjnych, a wręcz podważa autorytet państwa" ${ }^{205}$. Z kolei z tym postulatem i argumentami wypada się zgodzić.

W literaturze przedmiotu można także znaleźć pogląd, że Rozporządzenie Prezydenta Rzeczypospolitej z dnia I4 października I927 r. o uporządkowaniu stanu prawnego w organizacji gmin wyznaniowych żydowskich na obszarze Rzeczypospolitej Polskiej z wyjątkiem województwa śląskiego popadło w desuetudo $^{206}$. Nie jest to pogląd właściwy w zderzeniu z art. 36 Ustawy z dnia 20 lutego 1997 r. o stosunku Państwa do gmin wyznaniowych żydowskich w Rzeczypospolitej Polskiej, który to artykuł dokonuje wprost derogacji wspominanego wyżej rozporządzenia.

205 P. Borecki, Przeżytki ustawodawstwa wyznaniowego w polskim systemie prawnym, "Studia Iuridica” 59 (2014), s. 56.

206 Por. E. Goryczko, Autonomia i samorządność związów wyznaniowych w Polsce Ludowej, dz. cyt., s. 64. 
Trzeba także wyjaśnić, że to, iż niektóre z wyżej wymienionych aktów normatywnych to rozporządzenia prezydenta, a nie ustawy, nie umniejszało ich wagi w systemie prawa polskiego. Zgodnie bowiem z art. 44 Konstytucji Rzeczypospolitej Polskiej z dnia I7 marca I92I r. i Ustawy z dnia 2 sierpnia I926 r. o upoważnieniu Prezydenta Rzeczypospolitej do wydawania rozporządzeń z mocą ustawy ${ }^{207}$ akty te były na tym samym poziomie w hierarchii aktów normatywnych.

Niekiedy regulacja statusu prawnego kościołów i innych związków wyznaniowych cieszących się obecnie specjalną ustawą była w czasie II RP oparta na niepolskich aktach normatywnych. Miało to miejsce w przypadku:

I. Kościoła Mariawitów, który regulowany był aktem normatywnym - Объ исповъдующихъ въроученіе маріавитовъ, ІІ марта І9І2 (Zasady z dnia II marca I9I2 dotyczące wyznawców Kościoła mariawitów ${ }^{208}$.

2. Kościoła Ewangelicko-Reformowanego, którego działalność regulował dokument zatytułowany - О управленіи дълами Евангелическо-Реформатской Церкви въ губерніяхъ Царства Польскаго, 8 Февраль I849 (Ustawa z dnia 8 lutego I849 r. o zarządzie spraw Kościoła Ewangelicko-Reformowanego w Królestwie Polskim) ${ }^{209}$

3. Kościoła Baptystów, którego dotyczył Gesetz betreffend die Erteilung der Korporationsrechte an Baptistengemeinden vom 7. Juli I875 (Ustawa z dnia 7 lipca 1875 r. o nadaniu praw korporacyjnych gminom baptystów) ${ }^{210}$ oraz O форме книгъ для записи браков, рождения и смерти баптистовъ, 29 сентября I879 (Zasady z dnia 29 września I879 r. dotyczące prowadzenie ksiąg przez baptystów) ${ }^{211}$.

Można dodać, że brak specjalnej polskiej regulacji państwowej w okresie międzywojennym powodował, że - zgodnie z przyjętą ogólną zasadą - prawo zaborców obowiązywało w Polsce jedynie w tej części państwa, która

207 Dz.U. Nr 78, poz. 443.

208 „Полное собрание законов Российской Империиб” (Pełny Zbiór Praw Imperium Rosyjskiego), Петроградъ 19I5, Третье собрание, Том хxхіг, Часть I, No. 36718.

209 „Свод законов Российской империи” (Zbiór Praw Imperium Rosyjskiego), Санкпетербургъ І857, Книга третья, Томъ хі, Часть I, Глава II, No. Iо27-I035).

2 IO „Gesetz-Sammlung für die Königlichen Preussischen Staaten” (Zbiór praw dla Państw Królestwa Pruskiego) Berlin 1875, Nr. 27, Bon Nr. 8336, s. 374.

2 II „Полное собрание законов Российской империи” (Pełny Zbiór Praw Imperium Rosyjskiego), b.m.w. І9г2, Том 54, Часть 2, No. 60169. 
odpowiadała właściwemu dawnemu zaborowi, a więc jako prawo dzielnicowe. Zatem związek wyznaniowy uznany prawnie na terenie jednego $\mathrm{z}$ byłych zaborów mógł jednocześnie nie posiadać prawnego uznania na innych terenach. Jeżeli związek wyznaniowy nie miał uregulowanego statusu na ziemiach dawnych zaborów, to wówczas nie mógł prowadzić swojej działalności na tych terenach $^{212}$.

Zastosowanie tej ogólnej zasady do związków wyznaniowych uznawano w literaturze przedmiotu tego okresu za sprzeczne z konstytucją. Panowało przekonanie, że jeżeli dany związek religijny posiadał uznanie przynajmniej w jednej dzielnicy, to tym samym powinien mieć status wyznania na terenie całego $\mathrm{kraju}^{213}$. Jednakże przyjęta przez administrację zasada różnicowała uprawnienia związków wyznaniowych prawnie uznanych, przyznając tylko wyznaniom o określonym ustawowo stosunku do państwa status pełnoprawnej organizacji mogącej podejmować działalność na terenie całego kraju ${ }^{214}$.

Wymienione wyżej w pierwszych dwóch punktach akty normatywne obowiązywały aż do wejścia w życie Dekretu z dnia 5 września 1947 r. o uregulowaniu położenia prawnego Kościoła Ewangelicko-Reformowanego w Rzeczypospolitej Polskiej, Kościoła Mariawickiego i Kościoła Starokatolickiego ${ }^{215}$. Dekret ten w art. I stanowił, że „związki religijne istniejące na terenie Rzeczypospolitej, których byt prawny opiera się na przepisach obowiązujących tylko na części obszaru Państwa, a mianowicie: I) Kościół Ewangelicko-Reformowany w Rzeczypospolitej Polskiej, 2) Kościół Mariawicki i 3) Kościół Starokatolicki uzyskują charakter związków religijnych prawnie uznanych na obszarze całego Państwa”.

To wytłumaczenie w oparciu o tradycję prawną liczby Is podmiotów w zbiorze kościołów i innych związków wyznaniowych cieszących się dedykowaną im ustawą nie jest do końca pewne. Są bowiem wyjątki. Przykładowo Kościół Starokatolicki miał obowiązującą w czasie II RP własną regulację - Rozporządzenie austriackiego Ministerstwa Wyznań i Oświecenia z dnia I8 października I877 r.,

2 I2 Por. W. Wysoczański, M. Pietrzak, Prawo Kościołów i związków wyznaniowych nierzymskokatolickich $w$ Polsce, dz. cyt., s. 242. O przyczynach ustawowego nieuregulowania stosunków pisze K. Krasowski, Związki wyznaniowe w II Rzeczypospolitej. Studium historycznoprawne, Warszawa-Poznań 1988, s. 272-289.

2I3 Por. J. Demiańczuk, Uznanie prawne wyznań w świetle konstytucji, „Państwo i Prawo" (1948) nr 5-6, s. 45-46.

2I4 Por. K. Krasowski, Związi wyznaniowe w II Rzeczypospolitej..., dz. cyt., s. 287-289.

215 Dz.U. Nr 59, poz. 316 z późn. zm. 
którem orzeczone zostanie uznanie społeczności religijnej starokatolickiej ${ }^{216}$. Co więcej, miał on także prawne uznanie na terenie zaboru pruskiego zapewnione przez Gesetz betreffend die Rechte der altkatholischen Kirchengemeinschaften an dem kirchlichen Vermögen. Vom 4. Juli I875 (Ustawę z dnia 4 lipca I875 r. o prawach starokatolickich gmin kościelnych do majątku kościelnego) ${ }^{217}$. Obecnie związek ten nie ma własnej ustawy i znajduje się w rejestrze kościołów $\mathrm{i}$ innych związków wyznaniowych pod numerem IIo.

Natomiast Kościół polskokatolicki został uznany dopiero po II wojnie światowej, lecz tylko w trybie administracyjnym - przez decyzję ministra administracji publicznej. W piśmie z dnia I lutego $1946 \mathrm{r}$. napisał on, że Ministerstwo Administracji Publicznej uznaje w oparciu o art. II6 Konstytucji z I92I r. Narodowy Kościół Katolicki za publiczno-prawny związek religijny ${ }^{218}$. Formalne uznanie nastąpiło dnia 8 października 1947 r. wraz z uznaniem Kościoła Baptystów i Kościoła Adwentystów ${ }^{219}$. Podobnie Kościół Zielonoświątkowy zyskał uznanie prawne w wyniku Rozporządzenia Ministra Administracji Publicznej $\mathrm{z}$ dnia 23 marca 1946 r. ${ }^{220}$.

Prawna regulacja sytuacji Kościoła Metodystycznego sięga Dekretu z dnia I6 października 1945 r. o stosunku Państwa do Kościoła Metodystycznego w Rzeczypospolitej Polskiej ${ }^{221}$. Wcześniej bowiem, na skutek sprzeciwu Kościoła katolickiego, próby uznania go de iure nie zakończyły się sukcesem i metodyści działali na podstawie prawa o stowarzyszeniach ${ }^{22}$.

Dnia 5 sierpnia 1949 r. wydano dekret o ochronie wolności sumienia i wyznania. Zapewniono w nim wolność sumienia i wyznania wszystkim obywatelom (art. I) ${ }^{223}$. Natomiast dnia 6 sierpnia 1949 r. minister administracji publicznej wydał rozporządzenie w sprawie wykonania dekretu z dnia

2 I6 „Dziennik ustaw państwa dla królestw i krajów w Radzie państwa reprezentowanych" z I877 r., Nr 99, s. 210.

217 „Gesetz-Sammlung für die Königlichen Preußischen Staaten” (Zbiór praw dla Państw Królestwa Pruskiego) Berlin I875, Nr. 22, Bon Nr. 8329, s. 333-334.

2 I8 Za: W. Wysoczański, M. Pietrzak, Prawo Kościotów i związków wyznaniowych nierzymskokatolickich $w$ Polsce, dz. cyt., s. I6I.

219 Por. W. Wysoczański, M. Pietrzak, Prawo Kościotów i związów wyznaniowych nierzymskokatolickich $w$ Polsce, dz. cyt., s. 2I.

220 „Dziennik Urzędowy Ministra Administracji Publicznej” z dnia 24 października 1947 r., s. 8.

$22 \mathrm{I}$ Dz.U. Nr 46, poz. 259.

222 Por. K. Krasowski, Związki wyznaniowe w II Rzeczypospolitej..., dz. cyt., s. 3133I4, oraz s. 3I4, przyp. 24I.

223 Dz.U. z 1949 r. $\mathrm{Nr}$ 45, poz. 334. 
5 sierpnia 1949 r. o zmianie niektórych przepisów prawa o stowarzyszeniach ${ }^{224}$. $\mathrm{Na}$ jego podstawie możliwe było jedynie rejestrowanie albo zgłaszanie związków religijnych, które nie miały uznania prawnego jako stowarzyszenia $\left(\$_{3}\right)$.

\subsubsection{Tytuły ustaw}

Należy w tym miejscu zauważyć brak precyzji polskiego ustawodawcy w zakresie tytułów ustaw odnoszących się do kościołów i innych związków wyznaniowych.

Tytuł: Ustawa z dnia 17 maja 1989 r. o stosunku Państwa do Kościoła Katolickiego w Rzeczypospolitej Polskiej sugeruje, że nazwa tego związku wyznaniowego brzmi: „Kościół Katolicki w Rzeczypospolitej Polskiej”. Tej sugestii nie podtrzymuje art. I przedmiotowej ustawy, który nazywa Kościół, o którym mowa „Kościołem Katolickim”, czyli tak, jak brzmi oficjalna nazwa tego związku wyznaniowego. Nota bene tytuł tej ustawy w obecnym brzmieniu został ustalony z dniem I sierpnia I990 r. przez art. Is pkt I ${ }^{225}$ nieobowiązującej już Ustawy z dnia 5 lipca 1990 r. Prawo o zgromadzeniach ${ }^{226}$.

Natomiast w przypadku tytułu: Ustawa z dnia I7 maja 1989 r. o stosunku Państwa do Kościoła Ewangelicko-Augsburskiego w Rzeczypospolitej Polskiej, Kościół, którego ustawa dotyczy, nazywa się dokładnie tak, jak podano w tytule - „Kościół Ewangelicko-Augsburski w Rzeczypospolitej Polskiej”, co zresztą odnotowano w art. I ust. I tejże ustawy: „Kościół EwangelickoAugsburski w Rzeczypospolitej Polskiej, zwany dalej «Kościołem» [...]”. Tak samo jest w przypadku Kościoła Ewangelicko-Reformowanego w Rzeczypospolitej Polskiej, Kościoła Ewangelicko-Metodystycznego w Rzeczypospolitej Polskiej, Kościoła Chrześcijan Baptystów w Rzeczypospolitej Polskiej, Kościoła Adwentystów Dnia Siódmego w Rzeczypospolitej Polskiej, Kościoła Polskokatolickiego w Rzeczypospolitej Polskiej, Kościoła Katolickiego Mariawitów w Rzeczypospolitej Polskiej, Kościoła Starokatolickiego Mariawitów w Rzeczypospolitej Polskiej, Karaimskiego Związku Religijnego w Rzeczypospolitej Polskiej, Muzułmańskiego Związku Religijnego w Rzeczypospolitej

224 Dz.U. z 1949 r. Nr 47, poz. 358.

225 Art. I5: „W ustawie z dnia 17 maja I989 r. o stosunku Państwa do Kościoła Katolickiego w Polskiej Rzeczypospolitej Ludowej (Dz.U. Nr 29, poz. I54) wprowadza się następujące zmiany: I) tytuł ustawy otrzymuje brzmienie: „o stosunku Państwa do Kościoła Katolickiego w Rzeczypospolitej Polskiej”.

226 Dz.U. Nr 5I, poz. 297. 
Polskiej, Kościoła Zielonoświątkowego w Rzeczypospolitej Polskiej oraz Gmin Wyznaniowych Żydowskich w Rzeczypospolitej Polskiej.

Warto wspomnieć, że takiego błędu nie zrobiono przy Wschodnim Kościele Staroobrzędowym, „nie posiadającym hierarchji duchownej” oraz Polskim Autokefalicznym Kościele Prawosławnym. Poprawny tytuł ustawy regulującej stosunki między państwem a Kościołem katolickim powinien zatem brzmieć: Ustawa z dnia I7 maja I989 r. o stosunku Państwa do Kościoła Katolickiego.

\subsubsection{Perspektywa ustawodawcza}

Dawne brzmienie art. 8 ustawy o wolności sumienia i wyznania: „Kościoły i inne związki wyznaniowe w Polsce działają w konstytucyjnych ramach ustrojowych Polskiej Rzeczypospolitej Ludowej; ich sytuację prawną i majątkową regulują odrębne ustawy" nie dawało jasnego kryterium wskazującego, które związki wyznaniowe mogą mieć uregulowaną sytuację prawną poprzez ustawę. Obecnie artykuł ten ma brzmienie: „Kościoły i inne związki wyznaniowe w Polsce działają w konstytucyjnych ramach ustrojowych Rzeczypospolitej Polskiej; ich sytuację prawną i majątkową regulują przepisy rangi ustawowej”227. Oznacza to, że ustawa o gwarancjach wolności sumienia i wyznania została uznana za podstawę normowania sytuacji prawnej związków wpisanych do rejestru i po stronie państwa leży obowiązek skutecznego zapewnienia tej formy ułożenia wzajemnych stosunków ${ }^{228}$. Jak się wydaje, nie istnieje prawny obowiązek odpowiedzi ze strony związków wyznaniowych na ewentualne inicjatywy państwa dotyczące powstawania ustaw regulujących ich status prawny. Może to skutkować tym, że dobór podmiotów będzie arbitralny i całkowicie zależny od Rady Ministrów. W literaturze przedmiotu zwraca się uwagę, że może to skutkować „nadmierną polityzacją relacji pomiędzy państwem a związkami wyznaniowymi" 229 .

Obecnie bowiem podstawą prawną takich negocjacji jest zaaprobowany przez ministra spraw wewnętrznych i administracji dokument o tytule Tryb

227 Ustawa z dnia 26 czerwca 1997 r. o zmianie ustawy o gwarancjach wolności sumienia i wyznania oraz o zmianie niektórych ustaw (Dz.U. z I998 r. Nr 59, poz. 375).

228 Por. A. Czochara, Zakres podmiotowy art. 25 ust. 5 Konstytucji RP, [w:] Uktadowe formy regulacji stosunków między państwem a zwiąkami wyznaniowymi (art. 25 ust. 4-5 Konstytucji RP), red. P. Stanisz, M. Ordon, Lublin 20I3, s. 254.

229 T. Zieliński, Mankamenty uktadowego regulowania sytuacji prawnej związów wyznaniowych, „Przegląd Prawa Wyznaniowego” I (2009), s. 42. 
przygotowania $i$ zawierania umów o których mowa $w$ art. 25 ust. 5. Konstytu$c j i R P^{230} \mathrm{z}$ dnia $\mathrm{I} 6$ października $2008 \mathrm{r}$. Dokument ten został zaakceptowany przez prezesa Rady Ministrów pismem z dnia 30 czerwca 2009 r. Innym źródłem procedury negocjacji pomiędzy rządem a związkiem wyznaniowym są opracowane przez Departament Wyznań Religijnych oraz Mniejszości Narodowych i Etnicznych Ministerstwa Spraw Wewnętrznych i Administracji Zasady prowadzenia negocjacji przez Wydziat Regulacji Prawnych i Funduszu Kościelnego ${ }^{231} \mathrm{z}$ dnia 26 lutego $20 \mathrm{IO}$ r., które zostały zaakceptowane dnia 2 marca 2010 r. przez sekretarza stanu w Ministerstwie Spraw Wewnętrznych i Administracji ${ }^{232}$.

Zgodnie z danymi przekazanymi przez Departament Wyznań Religijnych oraz Mniejszości Narodowych i Etnicznych ${ }^{233}$ w okresie po 1989 r. do dnia 30 czerwca 2009 r., to jest do dnia zaakceptowania przez prezesa Rady Ministrów wspomnianego wyżej trybu przygotowania i zawierania umów, o których mowa w art. 25 ust. 5 Konstytucji RP, następujące kościoły i inne związki wyznaniowe złożyły wnioski o uregulowanie sytuacji prawnej w drodze ustawy:

I. Kościół Nowoapostolski (pierwotne prace - lata 90., potem kontynuowane po 2008 r.),

2. Stowarzyszenie Braci Muzułmańskich (5 grudnia 1997 r. - data wpływu wniosku),

3. Kościół Wolnych Chrześcijan (I lutego I999 r. - data wpływu wniosku),

4. Kościół Chrześcijan Wiary Ewangelicznej (I lutego 1999 r. - data wpływu wniosku),

5. Kościół Zborów Chrystusowych w Polsce (I lutego 1999 r. - data wpływu wniosku),

6. Kościół Ewangelicznych Chrześcijan (I lutego 1999 r. - data wpływu wniosku),

7. Zrzeszenie Wolnych Badaczy Pisma Świętego (8 marca 2004 r. - data wpływu wniosku),

230 DWRMNiE-0230-IO/O8/MPC.

23I DWRMNiE-O230-3/IO/MPC.

232 Procedurę opisuje P. Sobczyk, Negocjacje i zawarcie umowy z art. 25 ust. 5 Konstytucji $R$ P, [w:] Uktadowe formy regulacji stosunków..., dz. cyt., s. 277-288 oraz P. Sobczyk, Konstytucyjna zasada konsensualnego określenia stosunków między Rzecząpospolitą Polska a Kościotem katolickim, Warszawa 2013, s. 337-344.

233 Pismo Departamentu Wyznań Religijnych oraz Mniejszości Etnicznych, Ministerstwa Administracji i Cyfryzacji z dnia 30 października 20I5 r. do autora, DWRMNiE-WRPiFK.0I33I2.20I5 (archiwum prywatne autora, sygn. MAic/I). 
8. Kościół Ewangelicko-Augsburski w RP (2 lutego 2006 r. - data wpływu wniosku),

9. Wschodni Kościół Staroobrzędowy nie posiadający hierarchji duchownej (2 stycznia 2007 r. - data wpływu wniosku),

Io. Muzułmański Związek Religijny w Rzeczypospolitej Polskiej (4 marca 2008 r. - data wpływu wniosku).

Natomiast w okresie od dnia 30 czerwca 2009 r. do dnia 5 sierpnia 2015 r. wnioski w sprawie zawarcia umów pomiędzy Radą Ministrów a kościołami i innymi związkami wyznaniowymi w trybie art. 25 ust. 5 Konstytucji RP złożyły:

I. Kościół Ewangelicznych Chrześcijan w Rzeczypospolitej Polskiej (23 września 2009 r. - data wpływu wniosku),

2. Buddyjski Związek Diamentowej Drogi Linii Karma Kagyu w Rzeczypospolitej Polskiej (27 października 2009 r. - data wpływu wniosku),

3. Kościół Chrześcijan Wiary Ewangelicznej w Rzeczypospolitej Polskiej (8 stycznia 2010 r. - data wpływu wniosku),

4. Kościół Wolnych Chrześcijan w Rzeczypospolitej Polskiej (I8 stycznia 20Io r. - data wpływu wniosku),

5. Ewangeliczna Wspólnota Zielonoświątkowa (I8 stycznia 2010 r. - data wpływu wniosku),

6. Kościół Boży w Chrystusie (28 stycznia 20Io r. - data wpływu wniosku),

7. Wspólnota Kościołów Chrystusowych (obecnie: Kościół Chrystusowy) (26 lutego 20 Io r. - data wpływu wniosku),

8. Chrześcijańska Wspólnota Zielonoświątkowa (I2 marca 2010 r. - data wpływu wniosku),

9. Centrum Chrześcijańskie „Kanaan”, Centrum Chrześcijańskie „Miecz Ducha”, Wspólnota Chrześcijańska „Wrocław dla Jezusa”, Kościół Chrześcijański „Wieczernik”, Kościół Chrześcijański „Arka”, Kościół Chrześcijański „Słowo Wiary”, Kościół „Chrystus Dla Wszystkich”, Chrześcijański Kościół Reformacyjny, Kościół Boży w Polsce (2I kwietna zoıo r. - data wpływu wniosku),

Io. Kościół Ewangelicko-Augsburski w Rzeczypospolitej Polskiej (4 maja 20Io r. - data wpływu wniosku),

II. Islamskie Zgromadzenie Ahl-ul-Bayt (I2 listopada 2010 r. - data wpływu wniosku),

I2. Kościół Staroobrzędowy nie posiadający hierarchji duchownej (I8 lutego 2013 r. - data wpływu wniosku),

I3. Polski Narodowy Katolicki Kościół w Rzeczypospolitej Polskiej (4 lipca 2013 r. - data wpływu wniosku), 
I4. „Kanzeon” Związek Buddyjski, Związek Buddyjski Czan, Związek Buddystów Zen „Bodhidharma”, Związek Buddyjski Bencien Karma Kamtsang, Wspólnota Dzogczen w RP, Szkoła Zen Kwam Um, Związek Buddyjski Khordong w Polsce, Buddyjska Wspólnota Zen Kannon (20 listopada 2013 r. - data wpływu wniosku),

I5. Kościół Adwentystów Dnia Siódmego w Rzeczypospolitej Polskiej (3 listopada 2014 r. - data wpływu wniosku).

We wspomnianym okresie, poza wymienionymi już pracami nad zmianami w obowiązujących ustawach dotyczących Kościoła Ewangelicko-Augsburskiego w Rzeczypospolitej Polskiej i Muzułmańskiego Związku Religijnego w Rzeczypospolitej Polskiej, trwały prace nad projektami ustaw i umów kościołów zrzeszonych w Aliansie Ewangelicznym w RP oraz współpracujących z Aliansem, tj.:

I. Kościoła Ewangelicznych Chrześcijan w Rzeczypospolitej Polskiej,

2. Kościoła Chrześcijan Wiary Ewangelicznej w Rzeczypospolitej Polskiej,

3. Kościoła Wolnych Chrześcijan w Rzeczypospolitej Polskiej,

4. Ewangelicznej Wspólnoty Zielonoświątkowej,

5. Kościoła Bożego w Chrystusie,

6. Kościoła Chrystusowego w Rzeczypospolitej Polskiej,

7. Chrześcijańskiej Wspólnoty Zielonoświątkowej.

W dniach 28-29 lipca 20II r. przyjęto omawiane projekty umów i ustaw. Prace nad wspomnianymi projektami nie były następnie kontynuowane.

$Z$ kolei prace nad projektem ustawy regulującej stosunek państwa do Kościoła Nowoapostolskiego miały następujący przebieg - po przeprowadzeniu negocjacji w dniu 26 listopada 2013 r. Zespół Redakcyjny podpisał z przedstawicielami strony kościelnej protokół przyjęcia dokumentu legislacyjnego, przyjmując - jako wspólnie uzgodniony - projekt umowy i ustawy. Prace nad projektem nie były jednakże kontynuowane w Zespole Redakcyjnym.

Podobny przebieg miały prace nad projektem ustawy o stosunku państwa do Buddyjskiego Związku Diamentowej Drogi Linii Karma Kagyu w RP. W 2010 r. odbyło się jedno posiedzenie Zespołu Redakcyjnego powołanego w celu opracowania projektu stosownej umowy i projektu ustawy. Również w przypadku tego związku wyznaniowego prace nie były kontynuowane.

W świetle powyższych danych nieuzasadniony jest zarzut dyskryminacji przez państwo związków wyznaniowych nieposiadających odrębnych ustaw regulujących ich status. Rozmowy Rady Ministrów z przedstawicielami kościołów i innych związków wyznaniowych zmierzające do zawarcia umów będących podstawą ustaw były bowiem prowadzone. Niestety, nie wiadomo, 
dlaczego ich nie kontynuowano i nie doprowadzono do podjęcia wiążących decyzji i skierowania projektu ustawy do sejmu.

Można jednak podnieść w tym miejscu pewien zarzut dotyczący stanu prawnego. Jak słusznie zauważa się w literaturze przedmiotu, obecne brzmienie art. 8 ustawy o wolności sumienia i wyznania: „Kościoły i inne związki wyznaniowe w Polsce działają w konstytucyjnych ramach ustrojowych Rzeczypospolitej Polskiej; ich sytuację prawną i majątkową regulują przepisy rangi ustawowej” - nie jest odpowiednio mocno skorelowane z art. 25 ust. 5 Konstytucji RP, w którym stanowi się, że „Stosunki między Rzecząpospolitą Polską a innymi kościołami oraz związkami wyznaniowymi określają ustawy uchwalone na podstawie umów zawartych przez Radę Ministrów z ich właściwymi przedstawicielami" ${ }^{234}$. Słuszny jest więc postulat, aby regulacje określające szczegółowy tryb realizacji przepisu art. 25 ust. 5. Konstytucji RP znalazły się w odpowiedniej ustawie, np. w ustawie o gwarancjach wolności sumienia i wyznania, najlepiej bezpośrednio po dziale III dotyczącym rejestracji kościołów i innych związków wyznaniowych ${ }^{235}$.

Trzeba także zauważyć, że organ rejestrowy, jakim jest ministerstwo, nie ma żadnych narzędzi prawnych umożliwiających mu prowadzenie działań, które można by określić mianem polityki równouprawnienia kościołów i innych związków wyznaniowych. Może on jedynie w swoich działaniach być otwarty na rozmowy z kościołami i związkami wyznaniowymi.

\subsubsection{Wpis do rejestru kościołów i innych związków wyznaniowych}

Trzeba jednak pamiętać, że wymienione wyżej podmioty stanowią niewielką część organizacji religijnych, które nie posiadając dedykowanej im ustawy, są jedynie zarejestrowane przez Wydział Rejestru oraz Obsługi Organizacyjno-Administracyjnej Ministerstwa Spraw Wewnętrznych i Administracji. Tych

234 A. Czochara, Zakres podmiotowy art. 25 ust. 5 Konstytucji RP, dz. cyt., s. 254.

235 Por. A. D. Walencik, Zakres przedmiotowy art. 25 ust. 5 Konstytucji RP, [w:] Uktadowe formy regulacji stosunków..., dz. cyt., s. 275; W. Uruszczak, Art. 25 ust. 5 Konstytucji Rzeczypospolitej Polskiej. Problemy interpretacyjne, [w:] Pro bono Reipublicae. Ksiegga jubileuszowa Profesora Michata Pietrzaka, red. P. Borecki, A. Czohara, T. J. Zieliński, Warszawa 2009, s. 485. 
podmiotów, czyli kościołów i innych związków wyznaniowych jest I64, a organizacji międzykościelnych $5^{236}$.

Jeżeli członkowie zrzeszenia religijnego decydują się na skorzystanie z prawa do rejestracji, po stronie organu państwowego pojawia się obowiązek jej przeprowadzenia w oparciu o obowiązującą procedurę. Zgodnie z wyrokiem Wojewódzkiego Sądu Administracyjnego w Warszawie z dnia 8 kwietnia 20I4 r. ${ }^{237}$ odmowa wpisu do Rejestru kościołów i innych związów wyznaniowych może nastąpić jedynie na podstawie okoliczności wymienionych w art. 33 ust. 2 i 3 Ustawa z dnia I7 maja 1989 r. o gwarancjach wolności sumienia i wyznania. Nie jest możliwe odmówienie rejestracji na podstawie art. 2 ust. I tejże ustawy, czyli w przypadku, gdyby organ uznał, że ubiegający się o rejestrację związek wyznaniowy nie spełnia wymogów bycia wspólnotą religijną, założoną w celu „wyznawania i szerzenia wiary religijnej, posiadającą własny ustrój, doktrynę i obrzędy kultowe”.

Przekonanie organu o nieposiadaniu cech kościoła przez podmiot ubiegający się o rejestrację nie jest brakiem, o którym mowa w art. 32 ustawy. Zdaniem sądu nie każdy brak formalny wniosku dostrzeżony przez organ rejestrowy może być podstawą odmowy wpisu, ale tylko taki, który odnosi się do wymogów określonych w art. 32. Taka wykładnia mocno ogranicza dyskrecjonalną władzę organu rejestrującego i nie pozwala mu na wydanie decyzji o wpisie kościoła lub związku wyznaniowego do rejestru w oparciu o przesłanki ocenne.

Procedura rejestracji i wymagania stawiane kościołom i związkom wyznaniowym zawarte są w dziale III ustawy o gwarancji wolności sumienia i wyznania z $1989 \mathrm{r}$. w artykułach od 30 do $34^{238}$.

Rejestracja zrzeszenia niesie ze sobą zmianę sytuacji prawnej zarówno poszczególnych członków, jak i całej religijnej organizacji. W literaturze dyskutuje się, czy rejestracja ta jest korzystna dla religijnego zrzeszenia ${ }^{239}$. Przykłado-

236 Aktualny rejestr z datą publikacji 27.09.2016 r. znajduje się na stronie https://mswia.gov.pl/pl/wyznania-i-mniejszosci-relacje-panstwa-z-kosci/13964, Relacje-panstwa-z-Kosciolami-przydatne-informacje-dokumenty-i-akty-prawne.html (3.10.2016).

237 I SA/Wa I5I7/I3, Legalis nr 95098I.

238 Krytyczne przedstawienie tej procedury i wymogów rejestracyjnych zob. P. Kroczek, P. Ulman, Argument statystyczny $w$ rejestracji Kościołów i związków wyznaniowych - przyczynek do dyskusji, „Opolskie Studia Administracyjno-Prawne” I3 (2015) nr I, s. 6I-82.

239 Por. T. Szczech, Rejestracja kościołów i związów wyznaniowych-przywilej czy instrument kontroli?, [w:] Prawo państwowe a prawo wewnętrzne zwiąków wyznaniowych..., dz. cyt., s. 223-229. 
wo, wspominane korzyści wiążą się z tym, że wykonywanie aktu religijnego Kościoła lub innego związku wyznaniowego o uregulowanej sytuacji prawnej podlega ochronie prawnej (art. I95 $\$$ I k.k.). Inne korzyści mają charakter związany głównie z majątkowymi uprawnieniami rejestrowanego zrzeszenia religijnego. Dla przykładu można podać: zwolnienie z opodatkowania z tytułu przychodów z działalności niegospodarczej, zwolnienie z opodatkowania i ze świadczeń na fundusz gminny i fundusz miejski czy też zwolnienie z należności celnych na towary przeznaczone na cele charytatywno-opiekuńcze i oświatowo-wychowawcze oraz towary o charakterze kulturalnym przeznaczone na cele kultu (art. I3 u.g.w.s.w.). Inne przywileje dotyczą duchownych, którzy są , „w ramach obowiązujących przepisów ustaw zwolnieni z obowiązków niemożliwych do pogodzenia z pełnieniem funkcji duchownego lub osoby zakonnej" (art. I2 ust. I u.g.w.s.w.) $)^{240}$.

Można także zadać pytanie, czy rejestracja jest korzystna dla samego państwa. Wydaje się, że tak, dzięki rejestracji możliwa jest bowiem efektywniejsza koordynacja działań państwa i zrzeszeń religijnych w ramach realizacji zadań publicznych. Działania te obejmują dziedziny życia, które leżą w gestii zarówno państwa, jak i zrzeszeń religijnych, czyli przykładowo: walka z dyskryminacją i wykluczeniem, kształtowanie postaw społecznych, świadczenie pomocy socjalnej, nauczanie i wychowanie ${ }^{241}$. Część z tych zadań zrzeszenia religijne wypełniają jako własne. Inne są przez nie podejmowane dobrowolnie, na zasadzie pomocniczości wobec państwa, a niektóre mogą być tym zrzeszeniom zlecane przez państwo ${ }^{242}$.

Jako dodatek należy odnotować to, że podnosi się w literaturze prawnej postulat de lege ferenda, aby rozciągnąć prawo procedowania wyznaniowej formy zawarcia małżeństwa cywilnego na wspólnoty religijne wpisane do rejestru kościołów i innych związków wyznaniowych ${ }^{243}$. Obecnie taką możliwość

240 P. Kroczek, P. Ulman, Argument statystyczny $w$ rejestracji..., dz. cyt., s. 63-64.

24I Por. Commission of the European Communities, European Governance: A White Paper, сом (200I) 428, 25.07.200I, „Official Journal” C 287, vol. 44, I2.I0.200I, nr 8.

242 Por. J. Krukowski, Funkcje publiczne a osobowość publicznoprawna Kościotów, dz. cyt., s. 36; zob. także Z. Zarzecki, Rola Kościota i związków wyznaniowych w realizacji wybranych zadań z ustawy o pomocy spotecznej z dnia I2 marca 2004 r., „Studia z Prawa Wyznaniowego" 8 (2005), s. 73-I02; P. Kroczek, Prawny wymiar troski Kościota o rozwój cztowieka i spoteczeństwa, [w:] Rozwój i dobro wspólne. Dyskurs w 25-lecie encykliki „Sollicitudo rei socialis” Jana Pawta II, red. J. Mazur, Kraków 20I2, s. 7I-87.

243 Por. T. J. Zieliński, Rozciagnięcie prawa procedowania wyznaniowej formy zawarcia matżeństwa cywilnego na wspólnoty religijne wpisane do rejestru (propozycja „de 
mają wyłącznie niektóre kościoły i związki wyznaniowe spośród tych, które posiadają stosowną ustawę 24 . Zdaniem niektórych przedstawicieli nauki prawa obecny stan regulacji narusza normę równouprawnienia wyznań ustanowioną w art. 25 ust. I Konstytucji $\mathrm{RP}^{245}$. Jednakże w świetle danych statystycznych dotyczących liczby wiernych taki wniosek nie ma praktycznego uzasadnienia, a tym samym trudno go pogodzić z wymaganiami $\$$ I ust. I nr I i nr 3 ,Zasad techniki prawodawczej" 246 oraz z art. 34 ust. 2 pkt I i pkt 4 regulaminu $\mathrm{Sejmu}^{247}$. Nawet małżeństwa zawierane $\mathrm{w}$ trybie przepisanym w ustawach wyznaniowych stanowią bardzo niewielki ułamek małżeństw zawieranych w Polsce oraz małżeństw zawieranych w katolickiej formie kanonicznej ${ }^{248}$.

\subsubsection{Brak rejestracji administracyjnej}

Prawo zakładania kościołów i innych związków wyznaniowych wynikające z prawa do wolności religijnej (art. 53 Konstytucji RP oraz art. I ust. I u.g.w.s.w.) nie niesie ze sobą obowiązku ich rejestracji wobec władz państwowych. Ustawa o gwarancjach wolności sumienia i wyznania określa uprawnienie do rejestracji jako „prawo wpisu do rejestru kościołów i innych związków wyznaniowych” (art. 3 I u.g.w.s.w.) oraz „prawo wniesienia wniosku” (art. 32 ust. I u.g.w.s.w.).

lege ferenda”), „Przegląd Prawa Wyznaniowego” 4 (2012), s. I69-I73; zob. T. J. Zieliński, Stosowanie wyznaniowej formy zawarcia matżeństwa cywilnego poza Kościotem katolickim, „Państwo i Prawo” (20II) z. 2, s. 3I. 19-33.

244 Są to w kolejności alfabetycznej: Gminy żydowskie, Kościół Adwentystów Dnia Siódmego, Kościół Chrześcijan, Kościół Ewangelicko-Augsburski, Kościół Ewangelicko-Metodystyczny, Kościół Ewangelicko-Reformowany, Kościół katolicki, Kościół polskokatolicki, Kościół Starokatolicki Mariawitów, Kościół Zielonoświątkowy, Polski Autokefaliczny Kościół Prawosławny.

245 Por. M. Pietrzak, Prawo wyznaniowe, dz. cyt., s. 256; T. J. Zieliński, Stosowanie wyznaniowej formy zawarcia matżeństwa cywilnego poza Kościotem katolickim, dz. cyt., s. 3 I.

246 Rozporządzenie Prezesa Rady Ministrów z dnia 20 czerwca 2002 r. w sprawie „Zasad techniki prawodawczej” (tekst jedn. Dz.U. z 2016 r. poz. 283).

247 Uchwała Sejmu Rzeczypospolitej Polskiej z dnia 30 lipca 1992 r. Regulamin sejmu Rzeczypospolitej Polskiej (M.P. z 2012 r., poz. 32 z późn. zm.).

248 Por. P. Kroczek, Matżeństwo konkordatowe - ewaluacja przepisów po Is latach od wejścia w życie na przyktadzie przestanki z art. Io ust. I pkt I konkordatu, [w:] Konkordat-ocena z perspektywy Is lat obowiązywania, red. P. Kroczek, Kraków 20I4, s. 155-158 (Annales Canonici. Monographiae, 2). 
Realizacja wolności religijnej w Polsce może więc odbywać się w spontanicznie formowanych i swobodnie działających zrzeszeniach religijnych. Są to grupy legalnie istniejące, choć niezarejestrowane jako kościoły czy inne związki wyznaniowe.

Struktura wewnętrzna tych grup religijnych i ich działalność mogą być oparte na ich własnym prawie wewnętrznym, a nawet samorzutnie kształtowane poprzez zwyczaje lub praktykę członków tych zrzeszeń. Funkcjonowanie bez rejestracji może być wstępną formą działalności związku wyznaniowego, której następstwem będzie rejestracja. Nie jest to jednak konieczny etap. Jak słusznie zauważono, z powodu dobrowolnego charakteru prawa do rejestracji liczba faktycznie istniejących religijnych zrzeszeń oraz zarejestrowanych religijnych zrzeszeń nie będzie nigdy jednakowa ${ }^{249}$.

Wydaje się jednak, że mutatis mutandis można do ich prawa także zastosować rozważania z tego opracowania. Wspólną bowiem cechą tych organizacji jest zaspokajanie w formie zorganizowanej religijnych potrzeb ich członków.

\subsection{Prezentacja kościołów i innych związków wyznaniowych o uregulowanym przez ustawy stosunku do państwa oraz ich wewnętrznego prawa}

Wypada pokrótce przedstawić kościoły i związki wyznaniowe, których prawo endogeniczne będzie przedmiotem zainteresowania w III rozdziale książki, koncentrując się na faktach istotnych z punktu widzenia jej tematu, lecz nie pomijając danych statystycznych ${ }^{250}$. Należy jednak mieć świadomość, że kwestie statystyczne w przypadku kościołów lub innych związków wyznaniowych są niezwykle trudnym przedmiotem badań. Dane te dotyczą bardzo wrażliwego i intymnego wymiaru życia jednostek i społeczeństw, jakim jest religia i religijność. Nastręcza to określonych metodologicznych trudności ${ }^{251}$.

249 Zob. T. Zieliński, Pojęcie religii, wyznania, związku wyznaniowego i kościota w Konstytucji Rzeczypospolitej Polskiej, dz. cyt., s. 49.

250 Szersze omówienie Kościołów chrześcijańskich posiadających indywidualne ustawy oraz ich prawa wewnętrzne zob. M. Winiarczyk-Kossakowska, Ustawy III Rzeczypospolitej o stosunku państwa..., dz. cyt., s. 46-548; M. Plisiecki, Osoba prawna w prawie wewnętrznym kościotów o regulacji ustawowej, Warszawa 2013, szczególnie s. 90-139.

25I Zob. Główny Urząd Statystyczny, Wyznania religijne..., dz. cyt., s. 9-Io; P. Kroczek, P. Ulman, Argument statystyczny $w$ rejestracji..., dz. cyt., s. 72-74. 
Dodatkową trudnością jest wadliwość systematyki stosowanej przez Główny Urząd Statystyczny w publikacji pt. Wyznania religijne, stowarzyszenia narodowościowe $i$ etniczne $w$ Polsce 2009-20II ${ }^{252}$. Jej podstawowym kryterium jest bowiem nazwa kościoła, a nie doktryna. Do Kościołów katolickich zalicza się na przykład: Kościół Starokatolicki Mariawitów, Kościół Katolicki Mariawitów, Kościół Starokatolicki, Polski Narodowy Kościół Katolicki w RP. Tymczasem z doktrynalnego punktu widzenia jest to nieuprawnione. Kościoły te nie uznają przecież zwierzchniej władzy papieża, a także nie wyznają tych samych, co Kościół katolicki prawd wiary.

\subsubsection{Kościół katolicki}

Kościół katolicki w tej pracy rozważany jest jednak jako osoba prawna. Tak samo traktuje ten Kościół polski ustawodawca: „Kościół Katolicki, zwany dalej «Kościołem», działa w Rzeczypospolitej Polskiej we wszystkich swoich obrządkach” (art. I u.s.p.k.k). W Polsce Kościół katolicki działa jedynie w następujących obrządkach:

I. łacińskim - Kościół rzymskokatolicki,

2. bizantyjsko-ukraińskim - Kościół katolicki obrządku bizantyjsko-ukraińskiego,

3. bizantyjsko-słowiańskim - Kościół katolicki obrządku bizantyjsko-słowiańskiego,

4. ormiańskokatolickim - Kościół katolicki obrządku ormiańskiego.

W kanonicznym porządku prawnym te obrządki to niezależne Kościoły sui iuris.

Tak też je ujmuje w zestawieniach Główny Urząd Statystyczny, podając dane historyczne i statystyczne dla każdego z tych kościołów osobno.

Odnośnie do liczby katolików i odsetka wiernych w Polsce należy wyjaśnić pewną kwestię. Otóż według danych podanych przez Główny Urząd Statystyczny za 2012 r. (w końcu roku), rzymscy katolicy liczą 33399 328, grekokatolików jest 55 000, neounitów - I47, ormian - 5000, razem: 33459475 wiernych $^{253}$.

252 Pisał o tym już T. J. Zieliński, W sprawie klasyfikacji wyznań religijnych w Polsce, „Wiadomości Statystyczne” (1995) nr 4, s. 46-49.

253 Jest to liczba ochrzczonych. Zob. Główny Urząd Statystyczny, Rocznik statystyczny Rzeczypospolitej Polskiej 20I2, Warszawa 20I2, s. $2 \mathrm{I2}$. 
Jest to liczba ochrzczonych. Ta liczba stanowi $86,83 \%$ populacji Polski, która na 3I grudnia 2012 r. wynosiła 38533299 obywateli ${ }^{254}$.

Natomiast liczba deklarowana w czasie spisu powszechnego w $201 \mathrm{r}$ r. wynosiła dla rzymskich katolików 33728 700, a dla grekokatolików 33 330. Innych danych nie podano 255 .

Według innych danych podanych przez Główny Urząd Statystyczny sami rzymscy katolicy stanowią 95,5\% ludności Polski ${ }^{256}$. Tak duży odsetek wiernych wynika $z$ odniesienia liczby tzw. zobowiązanych (w Kościele katolickim ochrzczonych lub przyjętych do Kościoła po chrzcie świętym, zgodnie z zasadą semel catholicus, semper catholicus („kto raz katolik, zawsze katolik”, por. kan. II КРК) do liczby ludności zamieszkującej parafię.

Wskazane różnice dotyczące odsetka katolików w populacji Polski wynikają z innych metodologii badań. Chodzi mianowicie o to, że odsetek katolików w całej populacji uzyskuje się jako rezultat odniesienia liczby wiernych do liczby mieszkańców poszczególnych jednostek terytorialnych Kościoła ${ }^{257}$, a w konsekwencji uzyskiwanej przez Instytut Statystyki Kościoła Katolickiego sumy ludności Polski, która jest inna niż ta podawana przez Główny Urząd Statystyczny. Liczby wiernych są ustalane na poziomie parafii, a następnie w diecezjach. Skutkuje to zaniżeniem wielkości liczb w stosunku do wyników statystyki publicznej, a więc w porównaniu do danych Głównego Urzędu Statystycznego statystyka Kościoła katolickiego niedoszacowuje liczby ludności. Należy więc zakładać, że w konsekwencji ogólnie niedoszacowana jest również liczba wiernych ${ }^{258}$. „Można zatem stwierdzić, że liczba katolików obrządku łacińskiego zawiera się w przedziale od 86,7\% do 95,5\% ludności Polski”" ${ }^{259}$. Jednakże w kontekście masowych emigracji Polaków dane te nie są obecnie pewne.

254 Zob. Główny Urząd Statystyczny, Rocznik demograficzny 2013, Warszawa 2013, s. 76.

255 Zob. Główny Urząd Statystyczny, Rocznik demograficzny 20I4, Warszawa 20I4, s. 192.

256 Zob. Główny Urząd Statystyczny, Wyznania religijne..., dz. cyt., s. 36.

257 Por. objaśnienia w załącznikach nr 2 i 3 w Obwieszczenie Ministra Rozwoju i Finansów z dnia 24 października 2016 r. w sprawie stawek karty podatkowej, kwoty, do której można wykonywać świadczenia przy prowadzeniu niektórych usług z wyjątkiem świadczeń dla ludności, oraz kwartalnych stawek ryczałtu od przychodów proboszczów i wikariuszy, obowiązujących w 2017 r. (M.P. poz. II20) do ustawy z dnia 20 listopada 1998 r. o zryczałtowanym podatku dochodowym od niektórych przychodów osiąganych przez osoby fizyczne (Dz.U. z 1998 r. Nr I44, poz. 930 z późn. zm.).

258 Zob. Główny Urząd Statystyczny, Wyznania religijne..., dz. cyt., s. I6-I7.

259 Główny Urząd Statystyczny, Wyznania religijne..., dz. cyt., s. I7. 
Gdy chodzi o prawo endogeniczne, które będzie przedmiotem analizy w III rozdziale, to Kościół katolicki kieruje się dwoma podstawowymi aktami normatywnymi. Jednym z nich jest Codex Iuris Canonici auctoritate Ioannis Pauli PP. II promulgatus z dnia 25 stycznia $1983 \mathrm{r}^{260}$. Zgodnie $\mathrm{z}$ jego kan. I dotyczy on jedynie Kościoła łacińskiego. Katolickie Kościoły wschodnie natomiast rządzą się innym aktem normatywnym. Jest to Codex Canonum Ecclesiarum Orientalium auctoritate Ioannis Pauli PP. II promulgatus z dnia I8 października $1990 \mathrm{r}^{261}$.

Te akty normatywne - choć oba są kodeksami - wiele od siebie różni. Ich systematyka, zakres regulacji oraz niektóre rozwiązania prawne są odmienne. Mimo to można mówić o jednym prawie kanonicznym Kościoła katolickiego i w konsekwencji o jednym systemie prawnym obowiązującym w Kościele.

Równocześnie system ten cechuje duża spójność. Wyraża to przykładowo fakt, że zarówno kodeks prawa kanonicznego z 1983 r., jak i kodeks kanonów Kościołów wschodnich zawierają kanony świadczące o wzajemnych bliskich relacjach pomiędzy owymi zbiorami przepisów. Takie wzajemne prawne odniesienia mają zwykle charakter wyraźny, choć nie zawsze ${ }^{262}$. Poza tym istnieje duże podobieństwo, a niekiedy identyczność w sposobie regulacji spraw dla Kościoła najważniejszych. Do tych wspólnych spraw należą przykładowo te, które z natury rzeczy wiążą wszystkich katolików, np. o najwyższej władzy w Kościele, czyli Biskupie Rzymskim (kan. 33I KPK, kan. 43 KK Kw) i Kolegium Biskupów (kan. 336 KPK, kan. 49 KKKw). Także wtedy, gdy kanony łacińskiego kodeksu i kodeksu wschodniego przytaczają lub wyjaśniają prawo Boże, zarówno naturalne, jak i pozytywne (por. np. kan. IO84 \ I KPK i 80I I KKKW), obowiązuje pełna i niepodważalna łączność pomiędzy Kościołami, wyrażająca się w koherencji systemu prawa kanonicznego. Również kwestie źródeł prawa, interpretacji prawa, reguł walidacyjnych, które dla każdego systemu prawa

260 Codex Iuris Canonici auctoritate Ioannis Pauli PP. II promulgatus, 25.0I.I983, AAS 75 (1983), pars 2, s. I-30I; tekst łacińsko-polski: Kodeks prawa kanonicznego, przekład zatwierdzony przez Konferencję Episkopatu Polski, Poznań 1984. O ile nie zaznaczono inaczej, kanony cytowane w tym artykule pochodzą z tego aktu normatywnego.

26I Codex Canonum Ecclesiarum Orientalium auctoritate Ioannis Pauli PP. II promulgatus, I8.IO.I990, AAs 82 (1990), s. I045-I353; tekst łacińsko-polski: Codex Canonum Ecclesiarum Orientalium auctoritate Ioannis Pauli PP. II promulgatus, Kodeks kanonów Kościołów wschodnich. Promulgowany przez papieża Jana Pawła II, wydanie łacińsko-polskie, Lublin 2002.

262 Zob. J. Abbass, Two Codes in Comparison, Roma 2007, s. 284. 
są kluczowe, w wymienionych kodeksach są takie same (por. np. kan. 17-22 KPK i kan. 1504 KKKW).

Takie silne powiązanie Kościoła łacińskiego i Kościołów wschodnich poprzez prawo nie powoduje zatarcia różnic pomiędzy tymi wspólnotami. Przeciwnie, trzeba podkreślić, iż uznając jedność Kościoła, najwyższy prawodawca nie pozwala zapomnieć o różnicach w prawie Kościołów (zob. kan. I KPK $\mathrm{i}$ kan. I KKKw). Zawarte w kodeksach dyspozycje mają chronić z jednej strony jedność Kościoła, a z drugiej promować słuszną autonomię wszystkich katolickich Kościołów ${ }^{263}$.

\subsubsection{Polski Autokefaliczny Kościół Prawosławny}

Prawosławie jest jednym z trzech, obok katolicyzmu i protestantyzmu, podstawowych odłamów chrześcijaństwa. Swoje nauczanie opiera na Piśmie Świętym oraz Tradycji, przez którą rozumie: nauczanie kanonów św. Apostołów, nauczanie siedmiu powszechnych soborów, czyli do II Soboru Nicejskiego (787 r.), nauczanie dziesięciu lokalnych soborów, uznanych przez Święty Powszechny Kościół Prawosławny ( $\$ 2$ sWPAKP).

Wymienione sobory powszechne ustanawiały również kanony, które regulowały organizację i dyscyplinę Kościoła. Także sobory lokalne i poszczególni biskupi wydawali ustawy. W rezultacie prawosławie nie posiada ujednoliconego dla wszystkich Kościołów zbioru praw, czy też kodeksu. Istnieją kodeksy lokalne, które zwykle pochodzą ze średniowiecza. Nie są one ani wewnętrznie koherentne, ani spójne między sobą. Brakuje krytycznych opracowań podających, które przepisy mają nadal moc obowiązującą̨ ${ }^{264}$. „Trzeba jednak przyznać, że wielu z tych kanonów trudno dzisiaj przestrzegać, w niektórych przypadkach nie ma nawet możliwości ich zastosowania, przez co ulegają zapomnieniu. Jeśli dojdzie w końcu do zwołania nowego Soboru Powszechnego Kościoła, jednym z głównych jego zadań może być również rewizja i objaśnienie prawa kanonicznego" ${ }^{265}$.

263 Por. R. Sobański, Komentarz do kan. I, [w:] J. Krukowski, R. Sobański, Komentarz do Kodeksu Prawa Kanonicznego, t. I: Księga I, Normy ogólne, Poznań 2003, s. $46 \mathrm{nn}$.

264 Por. P. Evdokimov, Prawostawie, przeł. J. Klinger, Warszawa 2003, s. 196.

265 K. Ware, Kościót prawostawny, Warszawa 2002, s. 228-229. 
Prawosławie nie posiada centralnej władzy. Jego forma ustrojowa opiera się na autokefalii, czyli samodzielności poszczególnych Kościołów, które są niezależne od siebie administracyjnie i hierarchicznie. Zachowują jednak zgodność w kwestii głoszonych dogmatów i kultu i stanowią częśćskładową Kościoła powszechnego (\$ I ust. I SWPAKP). Polski Autokefaliczny Kościół Prawosławny zyskał niezależność w 1925 r. ${ }^{266}$. Wymagała ona zgodnego uznania wszystkich autokefalicznych Kościołów prawosławnych. Uzyskanie niezależności było wynikiem starań hierarchii prawosławnej w Polsce oraz zabiegów dyplomatycznych rządu polskiego ${ }^{267}$. Natomiast po II wojnie światowej Kościół ten dnia 22 czerwca 1948 r. uzyskał autokefalię od patriarchatu moskiewskiego, co było podyktowane także względami politycznymi. Kościół jest członkiem Polskiej Rady Ekumenicznej.

Należy dodać, że Kościół ten obejmuje swoją jurysdykcją wszystkie parafie prawosławne na terenie Polski oraz parafie prawosławne z terenu Brazyliii ${ }^{268}$.

Według danych prezentowanych przez Główny Urząd Statystyczny liczba jego wiernych wynosiła w 2011 r. $504 \mathrm{I}^{2629}$, jednakże w czasie spisu powszechnego w 20 II r. zadeklarowało przynależność do tego Kościoła tylko I56 300 osób ${ }^{270}$.

Prawną podstawą działalności tego Kościoła w Polsce jest Statut Wewnętrzny Polskiego Autokefalicznego Kościoła Prawosławnego z dnia io lutego $1995 r^{271}$, a także kanoniczne przepisy ojców Kościoła, reguły liturgiczne i reguły życia mniszego oraz uchwały soborów lokalnych ${ }^{272}$ ( $\$ 2$ SWPAKP). Statut tego Kościoła wymienia jeszcze inne źródła prawa wewnętrznego: statut parafialny, statut duszpasterstwa wojskowego oraz inne regulaminy, instrukcje

266 Zob. Sytuacja prawna Św. Autokefalicznego Kościoła Prawostawnego w Polsce, Warszawa I93I, s. 4I; W. Mossakowski, Ugruntowanie autokefalii prawostawia w Polsce wspótczesnej, „Studia Iuridica Toruniensia” II (20I2), s. II3-I28.

267 Szeroko o tym M. Bendza, Droga Kościota prawostawnego w Polsce do autokefalii, Białystok 2006.

268 Zob. M. Dziewiatowski, Wspólnota parafialna jako element historycznego trwania Kościota powszechnego. Studium przypadku sosnowieckiej wspólnoty parafialnej, 20I4, praca doktorska nieopublikowana, w posiadaniu autora.

269 Zob. Główny Urząd Statystyczny, Wyznania religijne..., dz. cyt., s. 51.

270 Zob. Główny Urząd Statystyczny, Rocznik demograficzny 20I4, dz. cyt., s. 192.

27I Zob. Mniejszości wyznaniowe w Polsce. Prawo wewnętrzne (statutowe), wprowadzenie, zbiór statutów, opracowanie R. Brożyniak, M. Winiarczyk-Kossakowska, Warszawa 20I4, s. I5-2I.

272 Zastanawiające jest, że użyto w tym, i tylko w tym przypadku liczby mnogiej. Przecież chodzi o ten sam organ - Sobór Lokalny, który zwoływany jest „w miarę potrzeby" ( $\$ 4$ ust. I SWPAKP). 
i przepisy. Są one uchwalane przez Święty Sobór Biskupów ( $\$ 8$ lit. n swaKP, art. 22 ust. 3 u.s.p.p.a.k.p.).

\subsubsection{Kościół Ewangelicko-Reformowany w Rzeczypospolitej Polskiej}

Kościół Ewangelicko-Reformowany w Polsce wywodzi się z XVI-wiecznej reformacji szwajcarskiej. Kościół ten uważa się za cząstkę Kościoła powszechnego powołanego przez Jezusa Chrystusa. Za najwybitniejszych reformatorów uważa Jana Husa, Marcina Lutra, Ulryka Zwingliego, Jana Kalwina i Jana Łaskiego (Wstęp, PWKE-R).

Wspólnota ta wyznaje, że Pismo Święte jest jedyną podstawą wiary i normążycia. Kościół przyjmuje apostolskie, nicejsko-konstantynopolitańskie i atanazjańskie wyznania wiary. Zasady wiary i porządek kościelny zostały systematycznie sformułowane w Drugiej konfesji helweckiej przyjętej w I566 r. oraz w Katechizmie heidelberskim z $1563 \mathrm{r}^{273}$. Konfesja helwecka została adaptowana do warunków polskich jako Konfesja sandomierska (Ugoda sandomierska) lub Konfesja polska w I570 r. Została ona odnowiona w 1970 r. Swoje nabożeństwa i posługi religijne Kościół ten normuje według Agendy gdańskiej z I637 r. (Wstęp, PWKE-R).

Kościół Ewangelicko-Reformowany w Rzeczypospolitej Polskiej jest członkiem Światowego Aliansu Kościołów Reformowanych, Konferencji Kościołów Europejskich (obydwie organizacje z siedzibami w Genewie) i Polskiej Rady Ekumenicznej.

W 201 r. Kościół ten liczył 3488 wiernych. Brak danych na temat deklaracji przynależności do tego Kościoła ze spisu powszechnego z 2OII r.

Kościół kieruje się prawem wewnętrznym sformułowanym w dokumencie: Prawo Wewnętrzne Kościoła Ewangelicko-Reformowanego w Rzeczypospolitej Polskiej, który wszedł w życie I stycznia 2015 r. ${ }^{274}$. Wiele norm znajduje się także w odpowiednich regulaminach (art. 54 pkt a PWKE-R).

273 Por. Z. Pasek, Wyznania wiary protestantyzmu..., dz. cyt., s. 38-58.

$274 \mathrm{http} / /$ www.reformowani.pl/index.php/czytelnia/26-prawo-wewnetrznekosciola-ewangelicko-reformowanegow-rzeczypospolitej-polskiej, (ı.ıо.20ı6.). 


\subsubsection{Kościół Ewangelicko-Augsburski w Rzeczypospolitej Polskiej}

Kościół Ewangelicko-Augsburski w Rzeczypospolitej Polskiej opiera swoją doktrynę wyłącznie na objawieniu zawartym w Piśmie Świętym, co wyraża formuła wiary - sola scriptura: „Wierzymy, nauczamy i wyznajemy, iż jedyną regułą i normą, według której powinno się oceniać i osądzać wszystkie nauki i wszystkich nauczycieli, nie może to być żadna inna, jak tylko prorockie i apostolskie pisma Starego i Nowego Testamentu” ${ }^{275}$ oraz „[... [ artykuły wiary ustala Słowo Boże, a poza tym nikt, nawet anioł (Ga I, 8)" ${ }^{276}$.

Zasady tej wiary zawierają, bardzo ważne dla luteranizmu, księgi wyznaniowe, zwane także księgami symbolicznymi ${ }^{277}$. Jest to corpus doctrinae, na który składają się wyznania wiary Kościoła oraz obowiązujący wykład jego nauki (Deklaracja wstępna, zPWKE-A, por. art. I ust. I u.s.p.k.e-a.). W jego skład wchodzą:

I. starokościelne symbole wiary: Nicejsko-konstantynopolitańskie wyznanie wiary, Apostolskie wyznanie wiary, Atanazjańskie wyznanie wiary,

2. Wyznanie augsburskie oraz Obrona Wyznania augsburskiego,

3. Maty katechizm,

4. Duży katechizm,

5. Artykuty szmalkaldzkie,

6. Traktat o wtadzy i prymacie papieza,

7. Formuta zgody.

Pisma te, ze względu na to, że wyłącznie Pismo Święte stanowi norma normans non normata doktryny, mogą być na nowo interpretowane i różnie wykładane. Jednakże „The Lutheran World Federation confesses the Holy Scriptures of the Old and New Testaments to be the only source and norm of its doctrine, life and service. It sees in the three Ecumenical Creeds and in the Confessions of the Lutheran Church, especially in the unaltered Augsburg Confession and the Small Catechism of Martin Luther, a pure exposition of the Word of God"278.

275 Formuta zgody, cz. I: Epitome. O zasadniczej regule i normie I, I, przekł. J. Pośpiech, [w:] Księgi wyznaniowe Kościoła luterańskiego, dz. cyt., s. 397.

276 M. Luter, Artykuty szmalkaldzkie II, I5, przekł. W. Niemczyk, [w:] Księgi wyznaniowe Kościota luterańskiego, dz. cyt., s. 340.

277 Zob. Księgi wyznaniowe Kościota luterańskiego, dz. cyt.

278 Constitution of the Lutheran World Federation, (as adopted by the LwF Eighth Assembly, Curitiba, Brazil, 1990, including amendments adopted by the LWF 
Kościół Ewangelicko-Augsburski w Rzeczypospolitej Polskiej miał w 2oII r. 6I 738 wiernych ${ }^{279}$, zaś deklarowanych było w owym roku 70800 członków ${ }^{280}$.

Kościół Ewangelicko-Augsburski w Rzeczypospolitej Polskiej jest członkiem Polskiej Rady Ekumenicznej, a także Światowej Federacji Luterańskiej, Światowej Rady Kościołów i Konferencji Kościołów Europejskich.

Prawo wewnętrzne tego Kościoła to Zasadnicze Prawo Wewnętrzne Kościoła Ewangelicko-Augsburskiego w Rzeczypospolitej Polskiej z dnia 26 października $1996 \mathrm{r}$. z późniejszymi zmianami ${ }^{28 \mathrm{I}}$. Jest to główny endogeniczny akt normatywny tego Kościoła. Do innych ważnych aktów prawa wewnętrznego należy zaliczyć:

I. Regulamin Parafialny - przyjęty na 2. Sesji Synodu Kościoła w dniach 26-28 października 2007 z późniejszymi zmianami ${ }^{282}$,

2. Regulamin Diecezjalny Kościoła Ewangelicko-Augsburskiego w Rzeczpospolitej Polskiej z dnia I8 lutego 2000 r. z późniejszymi zmianami ${ }^{283}$,

3. Regulamin Władz Zwierzchniczych z dnia 26 października 1996 r. z późniejszymi zmianami ${ }^{284}$,

4. Regulamin Wyborów Biskupa Diecezjalnego - bez daty uchwalenia, wszedł w życie z dniem I lutego 1997 r. z późniejszymi zmianami ${ }^{285}$,

Ninth Assembly, Hong Kong, I997 and by the LwF Eleventh Assembly, Stuttgart, 20I0), https://www.lutheranworld.org/sites/default/files/Constitution\%20EN\%2ofinal_o.pdf (25.07.2015) -, Światowa Federacja Luterańska wyznaje Pismo Święte Starego i Nowego Testamentu za jedyne źródło i normę swojej nauki, życia i służby. W trzech ekumenicznych wyznaniach wiary i w księgach wyznaniowych Kościoła luterańskiego, szczególnie w niezmienionym Wyznaniu augsburskim i w Małym katechizmie Marcina Lutra, widzi ona czysty wykład Słowa Bożego" (przeł. P. Kroczek).

279 Zob. Główny Urząd Statystyczny, Wyznania religijne..., dz. cyt., s. 57.

280 Zob. Główny Urząd Statystyczny, Rocznik demograficzny 20I4, dz. cyt, s. 192.

28I Zob. Tekst jednolity z I lipca 2016 r., http://bik.luteranie.pl/files/Prawo/20I607-orZasadniczePrawoWewntrzne.pdf (II.I0.20I6).

282 Tekst jednolity z 24 czerwca 2015 r., http://www.bik.luteranie.pl/files/Prawo/2015-06-24RegulaminParafialnytekstjednolityвıк.pdf (20.0I.20I6).

283 Tekst jednolity z I3 marca 2015 r., http://www.bik.luteranie.pl/files/Prawo/20150313RegulaminDiecezjalny.pdf (I2.03.2016).

284 Tekst jednolity z I6 grudnia 20II r. http://www.bik.luteranie.pl/files/Prawo/ RZWKTekstJednolityıosesjaxiısynodu.pdf (20.0I.20I6).

285 Tekst jednolity z 2 czerwca 2010 r. http://www.bik.luteranie.pl/files/Prawo/20I0-06-02RegulaminWyborwBiskupaDiecezjalnegozezmianamizzo620ıo-I.doc (20.01.2016). 
5. Regulamin Obrad Synodu Kościoła Ewangelicko-Augsburskiego w RP uchwalony podczas 6. Sesji XII Synodu w Warszawie w dniach I6-I8 października 2009 r. $^{286}$,

6. Przepisy dyscyplinarne Kościoła Ewangelicko-Augsburskiego w RP z dnia I8 października 2010 r. ${ }^{287}$,

7. Regulamin Rzecznika Dyscyplinarnego z dnia 27 maja 2013 r. ${ }^{288}$,

8. Pragmatykę Służbową Kościoła Ewangelicko-Augsburskiego w Rzeczypospolitej Polskiej z dnia 28 listopada 1999 r. z późniejszymi zmianami ${ }^{289}$, oraz „inne uchwały w zakresie ogólnych praw i przepisów kościelnych” (\$64 pkt 4 ZPWKE-A).

\subsubsection{Kościół Ewangelicko-Metodystyczny w Rzeczypospolitej Polskiej}

Wyznanie to wywodzi się od kierowanego przez Jana Wesleya oraz Karola Wesleya ruchu metodystycznego, który powstał w Kościele anglikańskim w I755 r., jako odłam o charakterze reformatorskim. Doktryna metodyzmu jest zbliżona do kalwinizmu. Za podstawę wiary uważane jest Pismo Święte oraz Apostolskie wyznanie wiary wyrażone w formie Artykułów wiary Kościoła Metodystycznego z 1784 r. ${ }^{290}$.

Kościół Ewangelicko-Metodystyczny w Rzeczypospolitej Polskiej opiera się na zasadach światowego odrodzeniowego ruchu metodystycznego, zachowując w sprawach wiary i osobistego doświadczenia zbawienia jedność poglądów z powszechnym Kościołem Metodystycznym o ustroju episkopalno-konferencyjnym (Preambuła, PWкE-M). Doktrynalna podstawa Kościoła zawarta jest $\mathrm{w}$ The Book of Discipline of the United Methodist Church'291 (Ksiega Dyscypliny

286 http://www.bik.luteranie.pl/files/Prawo/ros.pdf (20.0I.20I6).

287 Tekst ujednolicony przyjęty uchwałą Rady Synodalnej I5/20I5 z I3 listopada 2015 r., http://www.bik.luteranie.pl/files/Prawo/2015-II-I3PrzepisyDyscyplinarneujednoliconyrs.pdf (20.0I.20I6).

288 http://www.bik.luteranie.pl/files/Rada\%20Synodalna/RegulaminRzecznikaDyscyplinarnegotekstobow..pdf (20.0I.20I6).

289 Tekst jednolity z II kwietnia 2015 r., http://www.bik.luteranie.pl/files/Prawo/2016-07-orPragmatykaSubowa.pdf (20.01.2016).

290 Por. Z. Pasek, Wyznania wiary protestantyzmu..., dz. cyt., s. II6-I22.

29I The Book of Discipline of the United Methodist Church 2012, Nashville 2013. 
Zjednoczonego Metodystycznego Kościota $\left.{ }^{292}\right)$. Dokument ten został uchwalony i jest nowelizowany co 4 lata przez Konferencję Generalną. Inne akty normatywne zawierają Uchwały Konferencji Dorocznej i Uchwały Rady Kościoła.

Społeczno-doktrynalne nauczanie Kościoła wyrażają Zasady socjalne ${ }^{293}$, Wyznanie wiary oraz Zasady ogólne ${ }^{294}$. Zasady ogóle mają dla metodystów charakter doktrynalny, chociaż dotyczą spraw organizacyjnych. Odnoszą się one do wielu problemów dyscypliny osobistej i społecznej, a także takich zagadnien, jak znaczenie osobistej i wspólnotowej modlitwy, nabożeństw, traktowanych jako źródło etycznego działania ${ }^{295}$.

Kościół ten jest członkiem Polskiej Rady Ekumenicznej, wchodzi w skład Konferencji Generalnej i Centralnej Zjednoczonego Kościoła Metodystycznego oraz jest członkiem Światowej Rady Metodystycznej (art. 2 ust I u.s.p.k.e-m.).

Kościół posiada wspólnotę ołtarza i ambony z Kościołem Ewangelicko-Reformowanym w Rzeczypospolitej Polskiej od 1990 r. i od 1994 r. z Kościołem Ewangelicko-Augsburskim w Rzeczypospolitej Polskiej.

Liczba wiernych tego Kościoła w 201 r. wynosiła 4352. W spisie powszechnym w 20II r. nikt nie deklarował przynależności do niego.

Główna regulacja prawna to Prawo Wewnętrzne Kościoła Ewangelicko-Metodystycznego w Rzeczypospolitej Polskiej z dnia 25 maja 199I r. Ostatnich zmian dokonano w tej ustawie na Konferencji Dorocznej w dnia I8 kwietnia 2010 r. $^{296}$.

292 Fragmenty tej książki dotyczące zwłaszcza zagadnień doktrynalnych oraz organizacji i administracji Kościoła zostały opublikowane w piśmie „Methodos. Przegląd Teologiczno-Społeczny Wyższego Seminarium Teologicznego im. Jana Łaskiego Kościoła Ewangelicko-Metodystycznego w RP" 5-8 (2006-2009).

293 Zasady socjalne, dz. cyt.

294 Zasady ogólne, http://metodysci.pl/czytelnia/artykuly-wiary/zasady-ogolne/ (II.08.20I5).

295 Por. W. Benedyktowicz, Zasady Ogólne Kościota Metodystycznego, „Pielgrzym Polski” (I98I) nr 50I, s. 3.

296 Zob. Mniejszości wyznaniowe w Polsce..., dz. cyt., s. 43-56. Obecnie trwają prace Komisji ds. Prawa Wewnętrznego, którym od czerwca 2013 r. przewodniczy zwierzchnik Kościoła - ks. sup. Andrzej Malicki. Zadaniem Komisji jest przygotowanie projektu nowego Prawa Wewnętrznego, które będzie kompatybilne z Porządkiem Kościelnym Konferencji Centralnej Europy Środkowej i Południowej, czyli Księgą Dyscypliny dla tej Konferencji, w skład której wchodzi Kościół Ewangelicko-Metodystyczny w RP (List bp. A. Malickiego z dnia 9.IO.20I5r., archiwum prywatne autora, sygn. KEM/I). 


\subsubsection{Kościół Starokatolicki Mariawitów w Rzeczypospolitej Polskiej}

Mariawityzm to wyznanie, które wywodzi się z Kościoła katolickiego. Powstało ono w Polsce pod koniec xIx w. ${ }^{297}$. Nazwa wyznania pochodzi od wyrazów w języku łacińskim: Mariae vita, co oznacza „życie Maryi” (art. I $\$ I SKSM).

Powstanie mariawityzmu wiąże się z osobą Feliksy Magdaleny (imiona zakonne: Maria Franciszka) Kozłowskiej - „Mateczki”. Ta katolicka zakonnica żyjąca pod koniec XIX w. miała otrzymać prywatne objawienia. Nie zostały one jednak uznane przez Stolicę Apostolską, a sama Mateczka została ekskomunikowana. Ogłoszenie dekretu Kongregacji św. Oficjum (z 5 grudnia 1906 r.) w tej sprawie dnia 3I grudnia $1906 \mathrm{r}^{298}$ uważa się za datę wyłączenia mariawitów z Kościoła katolickiego.

Obecnie mariawici w Polsce zrzeszeni są w dwóch Kościołach powstałych po rozłamie Kościoła mariawickiego w 1935 r. Podział ten był spowodowany sporem o skalę kultu założycielki mariawityzmu oraz wprowadzeniem kapłaństwa kobiet. Pierwszy z tych Kościołów to Kościół Starokatolicki Mariawitów w Rzeczypospolitej Polskiej, a drugi, który będzie omówiony poniżej, to Kościół Katolicki Mariawitów w Rzeczypospolitej Polskiej.

Kościół Starokatolicki Mariawitów opiera swoją naukę na starokatolickich zasadach wiary i moralności, które zawarte są w Piśmie Świętym i Tradycji pierwotnej Kościoła, określonej w pierwszych siedmiu soborach ekumenicznych (art. I $\$ 2$ SKSM). Do Tradycji należy także objawienie Dzieła Wielkiego Miłosierdzia, którego autorką była założycielka Kościoła. Bez objawień Mateczki nie ma mariawityzmu, tym bardziej, że objawienie Dzieła Wielkiego Miłosierdzia jest dla mariawitów księgą wyznaniową ${ }^{299}$. Zasady życia mariawickiego opierają się także na trzech regułach św. Franciszka, czyli dotyczących zgromadzenia zakonnego męskiego, żeńskiego i pozostałych osób.

297 Najnowsze prace historyczne dotyczące mariawityzmu to np.: T. D. Mames, Mysteria mysticorum: szkice z duchowości i historii mariawitów, Kraków 2009; S. Rybak, Mariawityzm. Dzieje i wspótczesność, Warszawa $201 \mathrm{I}$.

298 Suprema Congregatio Sanctae Romanae et Universalis Inquisitionis, Decretum Mariavitarum sacerdotum quo choriphaei sectae Mariaviticae plectuntur excommunicatione maiori, nominali et personali, 5.I2.1906, AAS 40 (1907), s. 69-70; tekst polski dekretu w: S. Rybak, Mariawityzm..., dz. cyt., s. 5I-52.

299 Zob. Stowo wstępne Biskupa Naczelnego M. Wtodzimierza Jaworskiego, [w:] F. Kozłowska, Dzieto Wielkiego Mitosierdzia, Płock 2002, s. 6. 
Starokatolicki Kościół mariawitów jest członkiem Światowej Rady Kościołów i Konferencji Kościołów Europejskich oraz Polskiej Rady Ekumenicznej.

Liczba wiernych w $201 \mathrm{r}$ r. wynosiła $23436^{300}$, natomiast liczba zadeklarowanych to $10000^{301}$.

Prawo endogeniczne to głównie: Statut Kościoła Starokatolickiego Mariawitów z dnia 26 kwietnia 1967 r. ${ }^{302}$, ustawy kapłanów mariawitów i sióstr mariawitek, czyli Ustawy Zgromadzenia Kapłanów Maryawitów [sic!] Nieustającej Adoracyi [sic!] Ubłagania ${ }^{303}$ i Ustawy Zgromadzenia Sióstr Maryawitek [sic!] Nieustającej Adoracyi [sic!] Ubłagania ${ }^{304}$, Statut Związku Maryawitów Nieustającej Adoracyi Ubłagania $^{305}$, a także regulaminy uchwalone przez Radę Kościoła (art. viII $\$$ IO).

\subsubsection{Kościół Katolicki Mariawitów w Rzeczypospolitej Polskiej}

Jak już wskazano, Kościół ten wyodrębnił się w 1935 r. na skutek rozłamu w Kościele Mariawitów. W porównaniu z Kościołem Starokatolickim Mariawitów, Kościół ten opiera swoją naukę w dużym stopniu na prywatnych objawieniach założycielki - Marii Franciszki Kozłowskiej. W rezultacie została w tym Kościele zmieniona tradycyjna nauka o Trójcy Świętej, co jest niekiedy powodem niezaliczania tego Kościoła do Kościołów chrześcijańskich.

Poza podstawą w postaci Pisma Świętego i pierwszych siedmiu soborów, Kościół opiera się na „Objawieniu Bożym danym przez świętą Marię Franciszkę, Założycielkę Mariawityzmu, zapowiedzianą w Piśmie św. na czasy ostateczne Oblubienicę i Małżonkę Chrystusową, oraz na Ustawach Kościoła Mariawickiego" (\$ I sKKM). Inne podstawy doktrynalne zawarte są w listach pasterskich zwierzchników Kościoła: abp. Jana M. Michała Kowalskiego i abp. Józefa M. Rafaela Wojciechowskiego ${ }^{306}$.

300 Zob. Główny Urząd Statystyczny, Wyznania religijne..., dz. cyt., s. 44.

301 Zob. Główny Urząd Statystyczny, Rocznik demograficzny 20I4, dz. cyt., s. I92.

302 Mniejszości wyznaniowe w Polsce..., dz. cyt., s. 57-64. Statut ten ma zostać zastąpiony w 2016 r. prawem wewnętrznym - wywiad z biskupem M. L. Jabłońskim (archiwum prywatne autora, sygn. KSM/I).

303 Dzieto Wielkiego Mitosierdzia dla świata czyli Wypetnienie się objawienia św. Jana Apostota na staro-katolickim kościele maryawitów, Płock I922, s. 32I-338.

304 Dzieto Wielkiego Mitosierdzia dla świata..., dz. cyt., s. 339-373.

305 Dzieto Wielkiego Mitosierdzia dla świata..., dz. cyt., s. 317-320.

306 Ku królestwu Bożemu, Felicjanów 2009; J. M. R. Wojciechowski, Pisma wybrane - dzieto Bożego ratunku: mariawicki znak czasu, Felicjanów 2003. 
Kościół Katolicki Mariawitów w Rzeczypospolitej Polskiej liczy 1980 wiernych (dane na 20II r.) ${ }^{307}$. Wierni tego Kościoła nie zostali uwzględnieni w spisie powszechnym w $201 \mathrm{r} \mathrm{r}$.

Status prawny Kościołów mariawickich w Polsce jest dość podobny. Analiza przepisów ustaw konfesyjnych dotyczących tych Kościołów pozwala na stwierdzenie, że ich sytuacja prawna jest podobna, aczkolwiek nie identyczna. Istnieją pewne różnice, które wynikają z odmienności w doktrynie religijnej tych Kościołów oraz różnicach w wewnętrznej strukturze organizacyjnej ${ }^{308}$.

Ustawa wewnętrzna tego Kościoła to Statut Kościoła Katolickiego Mariawitów w Rzeczypospolitej Polskiej z dnia I4 maja I967 r. ${ }^{309}$. Został on „zredagowany" 2 stycznia $1968 \mathrm{r}^{3{ }^{30}}$. Obecnie trwają prace nad jego nowelizacją ${ }^{311}$.

Inne akty normatywne dla tego Kościoła to ustawy Kościoła oraz regulaminy ( $\$ 8$ ust. 5 SKKM). W zbiorze ustaw szczególne znaczenie mają: Ustawy Zgromadzenia Kapłanów Maryawitów Nieustającej Adoracyi Ubłagania ${ }^{312}$ oraz Ustawy Zgromadzenia Sióstr Maryawitek Nieustającej Adoracyi Ubłagania ${ }^{313}$.

\subsubsection{Wschodni Kościół Staroobrzędowy nieposiadający hierarchii duchownej w Rzeczypospolitej Polskiej}

Reformy przeprowadzone przez patriarchę Nikona i Cara Aleksego I Michajłowicza w Kościele prawosławnym z I656 r. spowodowały sprzeciw części duchowieństwa oraz wiernych Rosyjskiej Cerkwi Prawosławnej ${ }^{314}$. Z powodu prześladowań wyemigrowali oni na tereny dzisiejszej Litwy, Białorusi i Polski.

307 Zob. Główny Urząd Statystyczny, Wyznania religijne..., dz. cyt., s. 46.

308 Por. P. Kroczek, Status prawny mariawitów w Polsce, „Studia Oecumenica” I4 (20I4), s. 25I.

309 Mniejszości wyznaniowe w Polsce..., dz. cyt., s. 65-71.

3IO Por. M. Winiarczyk-Kossakowska, Ustawy III Rzeczypospolitej o stosunku państwa..., dz. cyt., s. 45o. Trwają prace nad nowelizacją tego statutu - list D. Szuigowicz, przewodniczącej Rady Przełożonych Kościoła Katolickiego Mariawitów, do autora z dnia I0.09.2015 r. (archiwum prywatne autora, sygn. KKM/I).

3 II Por. List z dnia I0.09.20I5 r. D. Szuigowicz, przewodniczącej Rady Przełożonych Kościoła Katolickiego Mariawitów (archiwum prywatne autora, sygn. KKM/I).

3I2 Dzieto Wielkiego Mitosierdzia dla świata..., dz. cyt., s. 317-338.

313 Dzieto Wielkiego Mitosierdzia dla świata..., dz. cyt., s. 339-373.

3 I4 Zob. E. Iwaniec, $Z$ dziejów staroobrzędowców na ziemiach polskich XVII-XX wieku, Warszawa 1977. 
Obecnie Kościół ten stanowi część Powszechnego Wschodniego Kościoła Staroobrzędowego ( $\$$ I swKs). Doktryna tego Kościoła jest zasadniczo zgodna z doktryną prawosławną, lecz odłam ten nie uznaje hierarchii duchownej (bezpopowcy). Źródłami wiary są: „, Słowo Boże zawarte w Piśmie Świętym i Biblii, 2) Tradycje Święte, czyli niepisane słowo Boże, które są zawarte: a) w Prawidłach Świętych Apostołów, b) w kanonach siedmiu powszechnych i dziewięciu prowincjonalnych Soborów, c) w Prawidłach Kanonicznych Ojców Św. przyjętych przez Sobory Powszechne, d) w przepisach kościelnych dotyczących odprawiania nabożeństw oraz statutów klasztornych uświęconych tradycją Św. Kościoła” ( $\$ 2$ swks).

Kościół ten liczył w $201 \mathrm{r}$ r. 1006 wiernych ${ }^{315}$. W czasie spisu nie ustalono liczby zadeklarowanych wiernych.

Prawo wewnętrzne to Statut Wschodniego Kościoła Staroobrzędowego nieposiadającego hierarchii duchowej zatwierdzony na posiedzeniu Naczelnej Rady Staroobrzędowców w dniu 25 marca 1984 r. z późniejszymi zmianami ${ }^{316}$. Został on uznany decyzją ministra-kierownika Urzędu do Spraw Wyznań dnia 30 października $1984 \mathrm{r}^{3{ }^{17}}$. Nowelizacji tego statutu dokonano podczas III Soboru dnia I8 lipca $1993 \mathrm{r}^{3{ }^{38}}$ Należy odnotować także, że viI Sobór dnia 30 sierpnia 2009 r. upoważnił Naczelną Radę Staroobrzędowców do „poprawek interpunkcyjnych, wynikających z życia Kościoła” (\$ 56 sw Ks).

Innymi źródłami prawa kanonicznego dla tego Kościoła są: „, S) Słowo Boże zawarte w Piśmie Świętym i Biblii, 2) Tradycje Święte, czyli niepisane Słowo Boże, które są zawarte: a) w Prawidłach Świętych Apostołów, b) w kanonach siedmiu powszechnych i dziewięciu prowincjonalnych Soborów, c) w Prawidłach Kanonicznych Ojców Świętych przyjętych przez Sobory Powszechne, d) w przepisach kościelnych, dotyczących odprawiania nabożeństw oraz statutów klasztornych uświęconych tradycją Świętego Kościoła” ( $\$ 2$ SWKSNH).

3I5 Zob. Główny Urząd Statystyczny, Wyznania religijne..., dz. cyt., s. 53.

316 Zob. Mniejszości wyznaniowe w Polsce..., dz. cyt., s. 72-78.

317 Decyzja ministra-kierownika Urzędu do Spraw Wyznań z dnia 30.10.1984 r., NR NK-803/29/I/84; zob. T. Radziwonowicz, Staroobrzędowcy $w$ regionie augustowsko-sejneńsko-suwalskim a wtadze w czasach PRL-u, [w:] Rosjanie na pótnocno-wschodnim Mazowszu w XIX wieku i pierwszej potowie XX wieku. Studia i materiaty, red. M. Gnatowski, Łomża 2009, s. 238.

3I8 Pismo Naczelnej Rady Staroobrzędowców z dnia 17.I2.1998 r. do Ministerstwa Spraw Wewnętrznych i Administracji, DD/DDI8/99 (archiwum prywatne autora, sygn. WKs/I). 


\subsubsection{Muzułmański Związek Religijny w Rzeczypospolitej Polskiej}

Muzułmański Związek Religijny w Rzeczypospolitej Polskiej jest najstarszą muzułmańską grupą wyznaniową w kraju. Przed I wojną światową muzułmanie w zaborze rosyjskim skupieni byli w gminach wyznaniowych, które podlegały muftiemu z Krymu. Po odzyskaniu przez Polskę niepodległości, w 1925 r. Wszechpolski Zjazd Gmin Muzułmańskich powołał do życia autokefaliczną organizację wyznaniową Tatarów polskich - Muzułmański Związek Religijny w RP na czele z muftim ${ }^{319}$.

Zasadnicze dewizy islamu to: jedność Boga, równość wiernych, braterstwo i sprawiedliwość społeczna ${ }^{320}$.

Muzułmanie swoją naukę dogmatyczno-moralną, a co za tym idzie także przepisy religijne, opierają na Koranie i Sunnie (\$ I pkt 6 sMZR2009, por. \$2 SMZRI936). Szersze ujęcie źródeł prawa muzułmańskiego według klasycznej teorii prawa obejmuje poza wymienionymi źródłami także konsensus (idżma) oraz analogię (kijas). Konsensus tworzą, w zależności od tradycji muzułmańskiej, muzułmańscy uczeni lub nieomylni imamowie, zaś analogia jest procesem indywidualnego logicznego rozumowania w sytuacji, gdy w Koranie lub Sunnie nie znaleziono żadnej podstawy do rozwiązania określonego problemu ${ }^{321}$.

Liczebność tego związku na $201 \mathrm{I}$ r. wynosiła 1132 osoby $^{322}$. Brak danych odnośnie do deklaracji członkostwa z 201 r. ${ }^{323}$.

319 Więcej o położeniu prawnym muzułmanów w okresie II RP zob. J. Sobczak, Potożenie prawne polskich wyznawców islamu, [w:] Islam a świat, red. R. Bräcker, S. Kitab, Toruń 2003, s. 172-204.

320 Por. J. Bielawski, Islam jako religia światowa, [w:] Zarys dziejów religii, dz. cyt., s. 769.

32I Por. S. W. Witkowski, Wprowadzenie do prawa muzutmańskiego. Wybrane instytucje, Warszawa 2009, s. 32-54.

322 Zob. Główny Urząd Statystyczny, Wyznania religijne..., dz. cyt., s. I2I.

323 Należy zwrócić uwagę, że muzułmanie w Polsce mają kilka związków wyznaniowych. Poza Muzułmańskim Związkiem Religijnym w Rzeczypospolitej Polskiej są to: Stowarzyszenie Jedności Muzułmańskiej, Stowarzyszenie Muzułmańskie Ahmadiyya, Islamskie Zgromadzenie Ahl-ul-Bayt oraz Liga Muzułmańska w Rzeczypospolitej Polskiej. Zob. Główny Urząd Statystyczny, Wyznania religijne..., dz. cyt., s. I20-I25. Wbrew temu, co niekiedy się podaje, Zachodni Zakon Sufi w Polsce nie jest związkiem religijnym łączącym muzułmanów, lecz organizacją związaną z ruchem New Age. „Sufizm nie jest religią, ale kierunkiem ezoterycznym opartym na praktyce indywidualnej i grupowej. Czerpie on z nauk wielkich nauczycieli duchowych świata, szuka punktów wspólnych 
Jeżeli chodzi o prawo wewnętrzne Muzułmańskiego Związku Religijnego w Rzeczypospolitej Polskiej, to pojawia się wątpliwość dotycząca mocy obowiązującej i zakresu obowiązywania dwóch statutów: Statutu Muzułmańskiego Związku Religijnego w Rzeczypospolitej Polskiej z dnia 26 sierpnia 1936 r. oraz Statutu Muzułmańskiego Związku Religijnego w Rzeczypospolitej Polskiej, który został uchwalony przez Nadzwyczajny Wszechpolski Kongres Muzułmańskiego Związku Religijnego w RP 28 lutego 2009 r. Statut ten nowelizowano dnia I5 marca $2014 \mathrm{r}^{324}$.

Zgodnie z Ustawą z dnia 2I kwietnia 1936 r. o stosunku Państwa do Muzułmańskiego Związku Religijnego w Rzeczypospolitej Polskiej ${ }^{325}$ obowiązujący jest statut z 1936 r., który stanowi załącznik do rozporządzenia Rady Ministrów z dnia 26 sierpnia 1936 r. o uznaniu Statutu Muzułmańskiego Związku Religijnego w Rzeczypospolitej Polskiej ${ }^{226}$. Jednakże ten związek wyznaniowy posługuje się obecnie statutem z 2009 r. i uznaje właśnie ten akt normatywny za swoje własne prawo wewnętrzne. Także autorzy zajmujący się kwestiami związanymi z Muzułmańskim Związkiem Religijnym uznają statut z 2009 r. za obowiązujący ${ }^{327}$. W literaturze przedmiotu istnieją również głosy przeciwne temu twierdzeniu ${ }^{328}$.

wszystkich religii i dążeń duchowych. Sufizm jest odłamem mistycznym i ezoterycznym Islamu” (Główny Urząd Statystyczny, Wyznania religijne..., dz. cyt., s. I62).

324 http://www.mzr.pl/pl/pliki/statut-20I4-0315.pdf (II.09.20I5). Poprzednia wersja jest w: Mniejszości wyznaniowe w Polsce..., dz. cyt., s. 79-91. Nota bene nowelizacja, o której mowa, nie tylko obejmowała gruntowną stylistyczną redakcję przepisów, lecz dokonano przez nią także zmian w regulacjach o istotnym znaczeniu. Przykładowo, rozszerzono zakres osobowy członków Wszechpolskiego Kongresu Muzułmańskiego, zmieniono częstotliwość odbywania się Zwyczajnych Kongresów MzR, a także ustalono, że mufti nie może być odwołany, co przewidywał statut w uchwalonej w 2009 r. wersji. W niniejszej książce przedmiotem analizy będzie znowelizowana wersja statutu.

325 Dz.U. Nr 30, poz. 240 z późn. zm.

326 Dz.U. Nr 72, poz. 517.

327 Np. M. Tomkiewicz, Ograniczenia alienacji nieruchomości Kościota katolickiego i muzutmańskich wspólnot religijnych - zakres recepcji w prawie polskim, [w:] In persona Christi. W stużbie pasterskiej obecności Chrystusa. Księga Jubileuszowa dedykowana Księdzu Profesorowi Antoniemu Misiaszkowi w 75. rocznicę urodzin, red. E. Wiszowaty, Olsztyn 2013, s. 449; M. Tomkiewicz, Zasada równouprawnienia kościotów i związów wyznaniowych a zakres ich autonomii w zarzadzaniu majątkiem na "forum externum" w Polsce, „Przegląd Religioznawczy” (2013) nr 4, s. 219; M. Tomkiewicz, Stużebność przesytu na gruntach podmiotów konfesyjnych w Polsce. Zagadnienia wybrane, „Przegląd Sądowy” (2014) nr 7-8, s. 52; tak też uznają R. Brożyniak, M. Winiarczyk-Kossakowska, autorzy opracowania Mniejszości wyznaniowe w Polsce..., dz. cyt.

328 Por. A. Nalborczyk, Status prawny muzutmanów w Polsce..., dz. cyt., s. 230. 
Kontrowersja, o której mowa, wynika z tego, że statut z 2009 r. nie został uznany przez państwo w drodze rozporządzenia Rady Ministrów. Taki warunek sine qua non obowiązywania statutu zawiera art. 2 ustawy o stosunku państwa do Muzułmańskiego Związku Religijnego. Opierając się na tym fakcie prawnym, wydaje się więc, że nadal obowiązuje statut z 1936 r. Natomiast statut z 2009 r., zgodnie z konstytucyjną zasadą wewnętrznej autonomii związków wyznaniowych wyrażoną w art. 25 ust. 3 Konstytucji RP powinien być, jak się wydaje, traktowany jako regulacja wewnętrzna, do której wydania każdy związek wyznaniowy ma prawo. Dodatkowo należy zauważyć, że statut z 2009 r. nie funkcjonowałby wówczas jako „Ustawa Wewnętrzna” (art. 2 u.s.p.m.z.r.). Tę rolę pełniłby nadal statut z r. 1936. Byłaby to więc sytuacja, w której obowiązują równolegle dwa akty normatywne: statut z 1936 r. w całości i statut z 2009 r. w części. Pierwszy z nich byłby aktem powszechnie obowiązującym, drugi zaś aktem wyłącznie wewnętrznym związku. Nota bene statut z 2009 r. nie zawiera żadnej klauzuli derogacyjnej dotyczącej statutu z $1936 \mathrm{r}$.

Oznacza to, że o ile statut z 1936 roku jest w całości elementem polskiego systemu prawnego - z racji jego publikacji w „Dzienniku Ustaw Rzeczypospolitej Polskiej”, to statut z 2009 r. jest jego elementem w zakresie, w którym prawo polskie dokonuje recepcji tego statutu. Zestawiwszy statut z 1936 r. ze statutem z roku 2009 pod kątem ich normatywnego znaczenia w systemie prawa polskiego należy stwierdzić, że zakres ich regulacji jest całkowicie rozłączny. Jeżeli jest jakaś materia pozostająca poza regulacją statutu z 1936 r., a prawo polskie dokonuje recepcji prawa wewnętrznego regulującego tę materię, to należy skorzystać z regulacji znajdującej się w statucie z 2009 r., o ile taka jest w nim zawarta.

Można dodać, że statut z 2009 r. został przekazany ministrowi spraw wewnętrznych i administracji do „wiadomości” ${ }^{29}$. Należy zastanowić się, czy ministerstwo nie popełniło błędu, nie rozpoczynając procedury zmierzającej do „uznania” tego statutu w trybie art. 2 ustawy z 1936 r.

Omawianą kwestię może komplikować to, że jak twierdzą niektórzy przedstawiciele doktryny prawniczej, z chwilą wejścia w życie Konstytucji z 1997 r. art. 2 ustawy dotyczącej muzułmanów utracił moc ${ }^{330}$. Jego realizację

329 Zob. Pismo Departamentu Bezpieczeństwa, Ministerstwa Spraw Wewnętrznych i Administracji z dnia I7 października 2016 r. do autora, DBI-Wodouip-o667-I-IOI/20I6, s. 2 (archiwum prywatne autora, sygn. MswiA/3).

330 Ten m.in. przepis wymienia i określa jako nieobowiązujący P. Borecki w artykule Status prawny muzutmanów we wspótczesnej Polsce (3), „Przegląd Tatarski” (20II) 
bowiem trzeba by było uznać za sprzeczną z art. 25 ust. 3 Konstytucji RP. Przy takim założeniu statut z 2009 r. byłby jedyną pełnoprawną endogeniczną podstawą działalności Muzułmańskiego Związku Religijnego w Rzeczypospolitej Polskiej (zob. \$ 5I SMZR2009) zarówno w stosunkach wewnętrznych, jak i wewnętrznych. Jednakże, jak zaznaczono już wyżej, twierdzenie takie jest błędne. Słuszne jest więc stanowisko Sądu Administracyjnego w Warszawie, który w wyroku z dnia 27 października 2015 r.h ${ }^{331}$ stwierdzil, że „Jedynym statutem «uznanym przez Państwo w drodze rozporządzenia Rady Ministrów» jest statut uznany rozporządzeniem Rady Ministrów z dnia 26 sierpnia 1936 r. o uznaniu Statutu Muzułmańskiego Związku Religijnego w Rzeczypospolitej Polskiej (Dz.U. Nr 72, poz. 517)”. Z kolei „Statut MZR w RP z 28 lutego 2009 r., [...] może być traktowany jedynie jako akt wewnętrzny, bez skutków wobec organów władzy publicznej, które działają na podstawie i w granicach prawa (zob. art. 7 Konstytucji RP, art. 6 k.p.a.)”. Podobnie sprawa została rozstrzygnięta przez Wojewódzki Sąd Administracyjny w Warszawie w wyroku z dnia ig lutego $2015 \mathrm{r}^{332}$.

Jeżeli przyjmie się, że obydwa statuty są obowiązującym prawem endogenicznym Muzułmańskiego Związku Religijnego, to wówczas dogłębne rozwiązanie kwestii zakresu obowiązywania obu statutów nie ma większego znaczenia dla rozważań dotyczących klauzul generalnych w nich zawartych. Dlatego też analizie zostanie poddany zarówno statut z 1936 r., jak i statut z 2009 r.

Inne akty normatywne wydawane przez ten związek wyznaniowy to regulaminy wewnętrzne opracowywane przez gminy muzułmańskie, przez które organizują one życie religijne swoich członków, sprawują nadzór nad udzielaniem im posług religijnych ( $\$ 30$ SMZR2O09).

$\mathrm{nr}$ 4, s. I8. Ten artykuł wraz z artykułami P. Borecki, Status prawny muzutmanów we wspótczesnej Polsce (I), „Przegląd Tatarski” (20II) nr I, s. 26-28 i P. Borecki, Status prawny muzutmanów we wspótczesnej Polsce (2), „Przegląd Tatarski” (20II) nr 2, s. 26-28 stanowi zmodyfikowaną wersję artykułu P. Borecki Potożenie prawne wyznawców islamu w Polsce, „Państwo i Prawo” (2008) z. I, s. 72-84.

33I I SA/Wa I250/I5, LEX nr 2030528.

332 I SA/Wa 2240/I4, LEX nr I654939. 


\subsubsection{Karaimski Związek Religijny w Rzeczypospolitej Polskiej}

Karaimi to nazwa wyznawców religii karaimskiej, jak również grupy etnicznej333. Karaimizm jako odrębna religia ukształtował się w vIII w. na terenie Iraku, w wyniku długotrwałej kontestacji tradycyjnego judaizmu, z którego odrzucał wszelkie komentarze talmudyczne. Twórcą podstaw religii był Anan syn Dawida z Basry (vir w.). Scalił on występujące w judaizmie prądy odrzucające Talmud, włączając zarazem pierwiastki zapożyczone z islamu i chrześcijaństwa. Doktryna przyjmuje pełną prawomocność indywidualnego rozumienia Biblii przez każdego wierzącego i wnioskowania na jej podstawie we wszystkich sytuacjach wymagających bieżących rozstrzygnięć. Za podstawę doktryny przyjmuje się Pięcioksiag Mojżeszowy, który jest tak doskonały, że nie może być zmieniany ani niczym uzupełniany. Dlatego też statut tego związu stanowi: „Przepisy religijne KzR zawarte są wyłącznie w Piśmie Starego Testamentu” (\$ I skzR). Chrystusa i Mahometa karaimi uznają za proroków ${ }^{334}$.

W 20II r. było IIs wyznawców ${ }^{335}$.

Statut tego związku został uchwalony dnia I8 marca I973 r. przez Karaimski Zjazd Delegatów Dżymatów ${ }^{336}$. Jest to ustawa wewnętrzna tego związku wyznaniowego zatwierdzona przez Urząd do spraw Wyznań Io maja 1974 r. ${ }^{337}$ Statut ten został znowelizowany przez Krajowy Zjazd Delegatów Karaimskiego Związku Religijnego w dniu 8 października 2oII r. ${ }^{338}$. Nie ma jednak informacji o zatwierdzeniu tej nowelizacji przez władze polskie ${ }^{339}$. W kontekście konstytucyjnych zasad autonomii związków wyznaniowych, jedynie na tej podstawie nie można jednak odmawiać tej nowelizacji mocy obowiązującej, nie rozstrzygając,

333 Por. G. Pełczyński, Najmniejsza mniejszość. Rzecz o Karaimach polskich, Warszawa 1995 .

334 Szerzej zob. A. Zajączkowski, Zarys religii karaimskiej, Warszawa 2003; S. Szyszman, Karaimizm. Historia i doktryna, Wrocław 2005.

335 Zob. Główny Urząd Statystyczny, Wyznania religijne..., dz. cyt., s. I5I.

336 Zob. Mniejszości wyznaniowe w Polsce..., dz. cyt., s. 92-97.

337 Urząd do spraw Wyznań, Decyzja z dnia I0.05.1974 r., Nr NK 803/2I/I/74.

338 Wersja znowelizowana przesłana przez S. Pileckiego (Przewodniczącego Zarządu Karaimskiego Związku Religijnego) w liście dnia I4.Io.20I5 r. (archiwum prywatne autora, sygn. KZR/2).

339 Zob. Pismo Departamentu Bezpieczeństwa, Ministerstwa Spraw Wewnętrznych i Administracji z dnia 17 października 2016 r. do autora, DBI-WodoUIP-0667-I-IOI/20I6, s. 2. (archiwum prywatne autora, sygn. MSWiA/3). 
podobnie jak to miało miejsce w przypadku statutów Muzułmańskiego Związku religijnego, o zakresie jego obowiązywania ${ }^{340}$.

\subsubsection{Kościół Polskokatolicki w Rzeczypospolitej Polskiej}

Kościół polskokatolicki powstał w końcu XIX w. na terenie Stanów Zjednoczonych. Został założony przez ks. Franciszka Hodura w I897 r. Jego celem była obrona interesów narodowych katolików polskiego pochodzenia, którzy byli marginalizowani przez kościelną hierarchię amerykańską ${ }^{341}$. W latach 20. ubiegłego stulecia Kościół został przeszczepiony do Polski.

Obecnie Kościół ten, będąc samodzielny i niezależny organizacyjnie od jakiejkolwiek zagranicznej władzy kościelnej i świeckiej, pozostaje w jedności wiary i moralności z Polskim Narodowym Kościołem Katolickim w Stanach Zjednoczonych Ameryki Północnej i Kanadzie (art. 2 ust. I i ust. 2 u.s.p.k.pk.).

Kościół polskokatolicki wyznaje katolickie prawdy wiary i moralności oraz zasady ustroju Kościoła zawarte w Piśmie Świętym. Przyjmuje on prawdy wiary sformułowane w powszechnych symbolach wiary i postanowieniach siedmiu soborów powszechnych pierwszego tysiąclecia (kan. I pkt a i pkt c PWKP).

Kościół polskokatolicki należy do Unii Utrechckiej Kościołów Starokatolickich (art. 2 ust. 3 u.s.p.k.pk.).

Kościół ten pod koniec $201 \mathrm{II}$ r. liczył 20402 wiernych $^{342}$. W tymże roku swoje członkostwo w nim zadeklarowało 8800 osób ${ }^{343}$.

Prawo Wewnętrzne Kościoła Polskokatolickiego w Rzeczypospolitej Polskiej zostało uchwalone przez Synod Ogólnopolski Kościoła Polskokatolickiego w Rzeczypospolitej Polskiej w dniu 27 czerwca $1995 \mathrm{r}$. i było nowelizowane przez synody ogólnopolskie. Tekst jednolity został przyjęty przez Radę Synodalną na posiedzeniu w dniu Io grudnia $2008 \mathrm{r}^{344}$.

340 Wszystkie odwołania do statutu karaimów w tej książce, choć zaczerpnięte były z jego wersji znowelizowanej, można odnieść do wersji statutu sprzed nowelizacji.

34I Zob. W. Wysoczański, Polskokatolicyzm. Geneza, dzieje, potożenie prawne, [w:] U. Küry, Starokatolicyzm. Historia, nauka, dażenia, tłum. i oprac. pod kier. W. Wysoczańskiego, Warszawa 1996, s. 425-459; H. Kubiak: Narodowy Kościót Katolicki w Stanach Zjednoczonych Ameryki w latach I897-1965. Jego spoteczne uwarunkowania i spoteczne funkcje, Wrocław-Warszawa-Kraków 1970.

342 Zob. Główny Urząd Statystyczny, Wyznania religijne..., dz. cyt., s. 42.

343 Zob. Główny Urząd Statystyczny, Rocznik demograficzny 20I4, dz. cyt., s. I92.

344 Zob. Mniejszości wyznaniowe w Polsce..., dz. cyt., s. 98-II8. 
Inne akty prawa wewnętrznego to przykładowo regulamin Sądu Biskupiego (kan. 132 PWKP), regulamin Komisji Rewizyjnej (kan. 139 PWKP), regulamin Funduszu Kościelnego (kan. I48 PWKP). Także uchwalone w dniu 5 lipca 1966 r. przez Piąty Ogólnopolski Synod Kościoła Zasady Wiary i Moralności Kościoła polskokatolickiego „stanowią integralną częśc” Prawa Wewnętrznego (kan. 6 PWKP).

\subsubsection{Kościół Adwentystów Dnia Siódmego w Rzeczypospolitej Polskiej}

Adwentyści wywodzą się historycznie z ruchu mesjanistyczno-eschatologicznego powstałego pod koniec XVIII w.

Sama nazwa ukazuje eschatologiczny, czyli głoszący bliskie przyjście Chrystusa, rys Kościoła - łac. adventus oznacza przyjście. Zaś określenie „dnia siódmego" odnosi się do soboty, która według Dekalogu jest siódmym dniem tygodnia - poświęconym na odpoczynek i kult Boga.

Kościół Adwentystów Dnia Siódmego przyjmuje Pismo Święte za jedyne źródło prawd wiary. „W Słowie tym Bóg przekazał człowiekowi wiedzę potrzebną do zbawienia. Pismo Święte jest nieomylnym objawieniem woli Bożej”345. Także „Standardy i działania Kościoła oparte są na zasadach Pisma Świętego” ${ }^{346}$. Jednakże prawdy te mogą być wykładane przez Kościół w formie zasad. Zmiany i uzupełnienia w tych zasadach mogą być dokonywane podczas Zjazdu Generalnej Konferencji. Kościół jest bowiem prowadzony przez Ducha Świętego do pełniejszego zrozumienia prawdy biblijnej lub lepszego sposobu jej wyrażania. Istnieje 27 głównych zasad wiary ${ }^{347}$.

W 20II r. Kościół liczył 9654 wiernych $^{348}$. Dane opublikowane ze spisu powszechnego nie wykazują członków tego Kościoła.

Statut Kościoła Adwentystów Dnia Siódmego w Rzeczypospolitej Polskiej uchwalono dnia I2 czerwca 2008 r., podczas xx Zjazdu Kościoła ${ }^{349}$. Był on nowelizowany uchwałami Synodu Kościoła na xxı Zjeździe Kościoła z dnia

345 Zasady Wiary Kościoła Adwentystów Dnia Siódmego, http://www.adwent. $\mathrm{pl} /$ o-kosciele/zasady-wiary (I0.09.2015), zasada nr I.

346 Prawo zborowe Kościoła Adwentystów Dnia Siódmego, przeł. Ł. Romanowski, red. M. Rakowski, A. Siciński, Warszawa 2013, s. I2

347 Zob. Z. Pasek, Wyznania wiary protestantyzmu..., dz. cyt., s. I34-I42.

348 Główny Urząd Statystyczny, Wyznania religijne..., dz. cyt., s. 65.

349 Zob. Mniejszości wyznaniowe w Polsce..., dz. cyt., s. II9-I25. 
30 maja 2013 r. i 3I maja 20I3 r. Tekst jednolity został sporządzony 3I maja $2013 \mathrm{r}^{350}$.

Należy pamiętać, że dla „całego ogólnoświatowego Kościoła, każdej organizacji kościelnej, każdego zboru i wszystkich członków Kościoła" moc wiążącą ma Prawo zborowe ${ }^{351}$. Zostało ono uchwalone podczas Zjazdu Generalnej Konferencji z Atlancie w 2010 r. Ogólnie mówiąc, Prawo zborowe to „podstawowy podręcznik zasad, praw i obyczajów” ${ }^{352}$, który „Opisuje [...] działania i cele zborów oraz ich stosunek do tych struktur Kościoła, których część stanowią"353. Norm Prawa zborowego należy przestrzegać we „wszystkich aspektach w odniesieniu do spraw administracyjnych i funkcjonowania zborów” i jednocześnie „Nie należy podejmować wysiłków na rzecz ustanawiania czy narzucania takich zasad przynależności do Kościoła lub takich przepisów i uregulowań dotyczących funkcjonowania zborów, które byłyby sprzeczne z decyzjami podjętymi podczas Zjazdu Generalnej Konferencji i przedstawionymi w niniejszym Prawie zborowym" 354 .

Należy zauważyć, że Prawo zborowe ma dwie części, które z perspektywy normatywnej różnią się od siebie. Pierwsza część ma wyraźnie prawny charakter - wyznacza ona w formie norm standardy lub ramy postępowania. Część druga natomiast, zatytułowana Uwagi, to materiał uzupełniający. Powstał on w wyniku przeklasyfikowania wybranych fragmentów Prawa zborowego z materiałów obligatoryjnych na materiały o charakterze doradczym, stanowiące zalecenia i przykłady35s. Przedmiotowa część zawiera „wskazówki, w jaki sposób zbór powinien postępować w różnych sytuacjach" ${ }^{356}$. Zbór może wybrać inną formę postępowania w konkretnej sprawie, jednakże rozwiązanie to powinno być zgodne z ogólnymi zasadami organizacji i funkcjonowania Kościoła ${ }^{357}$.

350 Zob. http://www.adwent.pl/component/attachments/download/396 (Io.IO. $2105)$.

35I Prawo zborowe Kościota Adwentystów Dnia Siódmego, dz. cyt., s. II.

352 Prawo zborowe Kościota Adwentystów Dnia Siódmego, dz. cyt., s. 7.

353 Prawo zborowe Kościota Adwentystów Dnia Siódmego, dz. cyt., s. II.

354 Prawo zborowe Kościota Adwentystów Dnia Siódmego, dz. cyt., s. I2.

355 Zob. Prawo zborowe Kościota Adwentystów Dnia Siódmego, dz. cyt., s. I3.

356 Prawo zborowe Kościoła Adwentystów Dnia Siódmego, dz. cyt., s. 223.

357 Zob. Prawo zborowe Kościota Adwentystów Dnia Siódmego, dz. cyt., s. 223. 


\subsubsection{Kościół Chrześcijan Baptystów w Rzeczypospolitej Polskiej}

Baptyści to ruch, który wywodzi się z Reformacji angielskiej, a dokładnie $\mathrm{z}$ radykalnego kalwinizmu angielskiego ${ }^{358}$.

Jego podstawę doktrynalną stanowią typowe dla protestantyzmu zasady. Kościół ten wierzy, że „Księgi święte Starego i Nowego Testamentu są przez Ducha Świętego prawdziwie natchnione i zawierają prawdziwe dla rodzaju ludzkiego objawienie Boże, są jedynym źródłem dokładnej wiedzy o Bogu, jak też zawierają zasady i wskazówki, jak powinniśmy wierzyć i postępować" 359 . Credo tego Kościoła jest wyrażone w Wyznaniu Wiary Kościoła Chrześcijan Baptystów w RP.

Od innych wyznań protestanckich odróżnia ten Kościół to, że chrzest udzielany jest osobom dorosłym. Akt ten jest bowiem pierwszym wyrazem wiary w Chrystusa i miłości wobec Niego, pierwszym krokiem posłuszeństwa Panu i aktem przyłączenia się do Jego zboru. Jest on także uroczystym oświadczeniem i wyznaniem wiary nawróconego grzesznika ${ }^{360}$.

W 20II r. Kościół Chrześcijan Baptystów w Rzeczypospolitej Polskiej liczył 4864 wiernych $^{361}$, a zgodnie ze spisem powszechnym z 20II r. - 6000 ${ }^{362}$.

Zasadnicze Prawo Wewnętrzne Kościoła Chrześcijan Baptystów w Rzeczypospolitej Polskiej pochodzi z dnia I października $2005 \mathrm{r} .{ }^{363} \mathrm{i}$ było zmieniane trzykrotnie uchwałami Krajowej Konferencji Kościoła - tekst jednolity z dnia I8 maja $2014 \mathrm{r}$.

Inne ważne akty normatywne dla tego Kościoła to: Regulamin Krajowej Konferencji Kościoła Chrześcijan Baptystów w Rzeczypospolitej Polskiej z dnia I października 2005 r. (tekst jednolity z dnia I7 maja 2013 r.) ${ }^{364}$, Re-

358 Zob. Londyńskie wyznanie wiary z 1698 roku (fragment), [w:] Z. Pasek, Wyznania wiary protestantyzmu..., dz. cyt., s. 105-107.

359 Wyznanie wiary baptystów polskich z 1930 r., art. I, oryginalna wersja w: Konfesja, czyli wyznanie wiary i ustrój zborów baptystów, dz. cyt.; uwspółcześniona wersja została wydana w Warszawie w $2000 \mathrm{r}$.

360 Wyznanie wiary baptystów polskich, art. 8.

36I Zob. Główny Urząd Statystyczny, Wyznania religijne..., dz. cyt., s. 63.

362 Zob. Główny Urząd Statystyczny, Rocznik demograficzny 20I4, dz. cyt., s. I92.

363 Zob. Mniejszości wyznaniowe $w$ Polsce..., dz. cyt., s. I26-134.

364 http://www.baptysci.pl/akty-prawne/I807-regulamin-krajowej-konferencji-kosciola-chrzescijan-baptystow-w-rzeczypospolitej-polskiej (I2.02.20I6). 
gulamin Rady Kościoła i Regulamin Prezydium Rady Kościoła (art. 42 pkt I3 ZPWкСнв) oraz przepisy wprowadzające Zasadnicze Prawo Wewnętrzne (art. 59 ZРWКСнв).

\subsubsection{Związek Gmin Wyznaniowych Żydowskich w Rzeczypospolitej Polskiej}

Gminy wyznaniowe żydowskie tworzą Związek Gmin Wyznaniowych Żydowskich w Rzeczypospolitej Polskiej. Związek został zarejestrowany w 1993 r. jako kontynuacja Związku Religijnego Wyznania Mojżeszowego, który powstał w 1946 r. i był prawnym kontynuatorem gmin przedwojennych ${ }^{365}$.

W skład Związku wchodzi 8 gmin: w Warszawie, Krakowie, Legnicy, Łodzi, Wrocławiu, Szczecinie, Bielsku-Białej, Katowicach i dwa oddziały we Wrocławiu i w Poznaniu ${ }^{366}$.

Członkiem gminy może zostać każda osoba narodowości żydowskiej lub pochodzenia żydowskiego (przynajmniej jedno z dziadków jest Żydem), jeśli nie jest wyznawcą innej religii.

Religijna doktryna judaizmu wywodzi się z 5 ksiagg Starego Testamentu, uzupełnionych o rabinacki kodeks religijno-prawny (Talmud), który dostarcza wykładni prawd biblijnych. Jej podstawowym elementem jest wiara w jedynego Boga, który z narodem żydowskim zawarł przymierze, uznając go za naród wybrany.

Judaizm nie posiada jednolitego wyznania wiary. Najpowszechniej akceptowaną próbą kodyfikacji zasad wywodzących się z Biblii i Talmudu jest zbiór I3 artykułów opracowanych przez Majmonidesa (II35-I204). Artykuły te ujęto w formie nakazów i zakazów. Jest ich 6I3 (248 nakazów i 365 zakazów).

Brak dokładnych danych statystycznych Głównego Urzędu Statystycznego dotyczących liczebności członków tego związku. Można ją szacować na około

365 Należy zwrócić uwagę, że nie wszystkie gminy żydowskie należą do tego związku. Przykładowo Niezależna Gmina Wyznania Mojżeszowego w Gdańsku, która powstała na skutek konfliktu między Związkiem Gmin Wyznaniowych Żydowskich a Przewodniczącym Gminy Wyznaniowej w Gdańsku jest niezależnym podmiotem ujętym w rejestrze pod numerem 150 .

366 Zob. Almanach żydowski 5776 (2015-2016), red. B. Szwarcman-Czarnota, Warszawa 20I5, s. 7I-I2O. 
o I230 wiernych ${ }^{367}$. Liczba należących w 2014 r. do wszystkich gmin, według danych Związku, to 1740 osób ${ }^{368}$.

Prawo wewnętrzne wyznaniowej wspólnoty żydowskiej w Rzeczypospolitej Polskiej zostało uchwalone w dniu Is stycznia $2006 \mathrm{r}^{369}$. Oprócz tego są różne przepisy regulujące działalność wspólnoty zawarte na przykład w regulaminach (zob. art. I4, art. $3 \mathrm{I}$ ust. 3, art. 32 ust. I pkt 3 Pwwwż) czy innych aktach normatywnych (art. 36 pkt 8 PWwwż).

\subsubsection{Kościół Zielonoświątkowy w Rzeczypospolitej Polskiej}

Ruch zielonoświątkowy zwany także pentekostalnym powstał w Stanach Zjednoczonych na początku xx w. Jego nazwa wywodzi się od greckiego słowa pentekoste oznaczającego pięćdziesiąty dzień po Wielkanocy, czyli dzień zesłania Ducha Świętego.

Kościół Zielonoświątkowy w Rzeczypospolitej Polskiej ukonstytuował się na mocy uchwały przyjętej przez Synod Założycielski obradujący w dniach 22-23 maja 1987 r. Kościół ten jest kontynuacją dwóch nurtów ruchu zielonoświątkowego: Związku Stanowczych Chrześcijan (od I9Io r.) i Kościoła Chrześcijan Wiary Ewangelicznej (od I929 r.) oraz wspólnoty Zjednoczonego Kościoła Ewangelicznego (partycypacja: Stanowczy Chrześcijanie od 1947 r., Chrześcijanie Wiary Ewangelicznej od 1953 r.) (art. I ust. I i ust. 2 PWKz).

Dlatego w łączności z innymi chrześcijanami wierni Kościoła Zielonoświątkowego wyznają swoją wiarę słowami apostolskiego i nicejsko-konstantynopolitańskiego wyznania wiary. Zbory tworzące Kościół Zielonoświątkowy w Rzeczypospolitej Polskiej stanowią cząstkę Kościoła powszechnego, Ciała, którego Głową jest Jezus Chrystus, Pan i Zbawiciel (art. I ust. 3 PWKZ).

Kościół jest częścią składową współczesnego ruchu zielonoświątkowego należy do Europejskiego Aliansu Zielonoświątkowego, Światowej Wspólnoty Zborów Bożych oraz Aliansu Ewangelicznego.

367 Zob. Mniejszości wyznaniowe w Polsce..., dz. cyt., s. I35.

368 Informacja uzyskana w sekretariacie Związku Gmin Żydowskich w Warszawie dnia I8.09.20I5 r. (archiwum prywatne autora, sygn. ZĠ̇/I).

369 Zob. Mniejszości wyznaniowe w Polsce..., dz. cyt., s. 135-144. 
W 20II r. Kościół ten liczył 22429 wiernych $^{370}$. Ze spisu powszechnego wynika, że było ich $26400^{371}$.

Prawo Wewnętrzne Kościoła Zielonoświątkowego w Rzeczypospolitej Polskiej uchwalone przez Synod Nadzwyczajny dnia 28 września 2007 r. ${ }^{372}$ określa, obok ustawy o stosunku państwa do Kościoła Zielonoświątkowego i ustawy o gwarancjach wolności sumienia i wyznania, „sytuację prawną Kościoła” (art. 3 ust. I pkt 3 PWKz).

370 Zob. Główny Urząd Statystyczny, Wyznania religijne..., dz. cyt., s. 72.

37I Zob. Główny Urząd Statystyczny, Rocznik demograficzny 20I4, dz. cyt., s. 192.

372 Akt ten był nowelizowany przez Synod Kościoła w dniach: i6.09.20II r., 20.09.20I3 r. i I9.09.20I4 r., 25.09.20I5 r., http://kz.pl/kzw/wp-content/uploads/2009/o9/ Prawo-Wewnętrzne-KZ-20I5.pdf (Io.IO.2016). 



\section{Prawo endogeniczne kościołów i innych związków wyznaniowych}

Po przedstawieniu w I rozdziale zagadnienia statusu prawnego kościołów i innych związków wyznaniowych w Rzeczypospolitej Polskiej, dla realizacji celu książki w II rozdziale należy zwrócić uwagę na prawo endogeniczne tych zrzeszeń. W tej części chodzić będzie o poznanie fenomenu prawa religijnego, jego specyfiki oraz podobieństw i różnic w odniesieniu do prawa polskiego.

\subsection{Stosunek kościołów lub innych związków wyznaniowych do własnego prawa endogenicznego}

Pierwszym zagadnieniem, które należy omówić w celu przedstawienia właściwego podejścia do religijnego prawa i jego wykładni, jest stosunek wspólnot religijnych do własnego prawa, czyli prawa endogenicznego. Nie chodzi bowiem o ich stosunek do prawa Bożego, który z oczywistych względów musi być pozytywny, ani o stosunek do prawa państwowego, bo ten wyraża się zasadniczo w stosunku związków wyznaniowych do państwa jako takiego. Chodzi tu o stosunek religijnego zrzeszenia do prawa wewnętrznego powstałego na forum tego związku. Wydaje się, że ten stosunek jest uzależniony od tego, jak związek wyznaniowy rozumie sam siebie. Stąd też przy prezentacji tego tematu konieczne jest odniesienie do myśli doktrynalnej związków wyznaniowych. W badanej dziedzinie można wyróżnić różne koncepcje.

\subsubsection{Koncepcja obcości prawa}

Związki wyznaniowe mogą być a priori nastawione antyprawnie (antynomicznie). Obrazem takiej postawy może być opinia wyrażona przez Rudolfa Sohma, 
protestanckiego prawnika, teologa i historyka, który rozważania na temat relacji prawa i Kościoła podsumował zdaniem: „Das Wesen der Kirche ist geistlich, das Wesen des Rechtes ist weltlich. Das Wesen des Kirchenrechtes steht mit dem Wesen der Kirche in Widerspruch”'. Opierając się na powyższym twierdzeniu, można powiedzieć, że dla wspólnoty religijnej prawo jest czymś obcym. Kościół jest bowiem Kościołem miłości, czyli tworem duchowym.

Nie oznacza to, że w tej wspólnocie nie obowiązuje żadne prawo lub że nie ma ona własnego prawa stanowionego, choć i taką sytuację należy założyć2. Jednakże jego obecność, czy to w postaci zwyczajów prawnych, czy to w formie prawa stanowionego, jest elementem niepożądanym lub przynajmniej obojętnym z religijnego punktu widzenia.

Konieczność istnienia prawa we wspólnocie może mieć różnorodne źródła. Od strony zewnętrznej źródłem tym może być nakaz państwa, wymuszający na kościele lub związku wyznaniowym posiadanie statutu w celu administracyjnej rejestracji tego związku. Od strony wewnętrznej źródłem prawa może być konieczność uporządkowania życia i funkcjonowania wspólnoty. Wówczas prawo wewnętrzne jest konsekwencją socjologiczno-prawnej reguły ubi societas ibi ius („Gdzie społeczność, tam i prawo”).

Tą maksymą starożytni wyrażali słuszny pogląd, według którego każda społeczność ludzka, niezależnie od jej pochodzenia, struktury, celów, cechuje się tym, że istnieje w niej fenomen prawa ${ }^{3}$.

\subsubsection{Koncepcja częściowej akceptacji prawa}

Inną koncepcją stosunku do prawa wewnętrznego jest ta reprezentowana przez Marcina Lutra. Reformator odróżniał Boże prawo (ius divinum) obecne w Kościele i prawo kościelne ustanowione przez człowieka dla Kościoła

I R. Sohm, Kirchenrecht, vol. I: Die geschichtlichen Grundlagen, Leipzig I923, s. 700: „Kościół ma duchową naturę, prawo natomiast ziemską. Natura prawa kanonicznego stoi w opozycji do natury Kościoła” (przeł. P. Kroczek).

2 Sytuację braku prawa w akatolickim Kościele lub związku wyznaniowym zakłada prawodawca Kościoła katolickiego. Zob. art. art. $2 \$ 2$ i $2^{\circ}$ instrukcji Dignitas connubii.

3 Zob. L. Pospisil, Anthropology of Law: a Comparative Theory, New York 197I, s. 343. Szeroko o tym zagadnieniu pisze np. S. F. Moore, Law and Anthropology, „Biennial Review of Anthropology" 6 (1969), s. 252-300. 
(Kirchenordnung). Zgodnie z prawem Bożym Kościół ma pełnić służbę Ewangelii. Ci, którzy należą do Chrystusa, podlegają wewnętrznej władzy: „Do Jego Królestwa [...] nie należy ani miecz, ani świeckie prawo, ale tylko Słowo Boże i Duch”" Kościół nie może w tym duchowym porządku podejmować żadnych aktów stanowienia prawa. Ma on jedynie realizować nakazy Pana. „Bóg nie pozwoli, aby ktokolwiek rządził w tym obszarze jak tylko On sam”s. Jednakże zgodnie z porządkiem ludzkim Kościół stanowi prawo, którego zadaniem jest regulowanie kościelnych urzędów i ich współpraca z pozostałymi członkami Kościoła. Prawo to jest stanowione dla celów praktycznych. Chodzi o to, aby dzięki normom prawnym wzmacniać rozwój wewnętrzny człowieka przez zewnętrzne środki i działania. Źródłem tego prawa nie jest wiara (ordinatio fidei), lecz rozum (ordinatio rationis), a jego istnienie jest koniecznością dla wspólnoty (necessitas fratris).

Prawo to ma dwa źródła. Pierwsze z nich jest heteronomiczne. Na to źródło składają się zewnętrzne akty stanowienia prawa przez tych, którzy z ustanowienia Bożego sprawują władzę - także władzę świecką. Drugie źródło to autonomiczne stanowienie prawa dokonywane przez consensus fratrum („zgodę braci”). Ta droga to wcielanie w życie wspólnoty zasady miłości bliźniego ${ }^{6}$. Jednakże ani jedno, ani drugie źródło tworzenia prawa, a nawet oba źródła razem, nie są w stanie oddać całej woli Boga względem ludzi czy też dać pewnej i jasnej odpowiedzi na wszystkie pytania, które powstają wraz z konfliktami w obrębie wspólnoty wiernych?

Wydaje się, że tę samą formę stosunku do własnego prawa ma Kościół Adwentystów Dnia Siódmego. W Prawie zborowym tak wyjaśniono ratio tego zbioru: „Aby Kościół mógł we właściwy sposób spełnić rolę instytucji służącej Panu Bogu i ludzkości, konieczny jest porządek, władza i dyscyplina. Pismo Święte zaleca: «a wszystko niech się odbywa godnie i w porządku»

4 M. Luter, O świeckiej zwierzchności, w jakiej mierze należy być jej postusznym, dz. cyt., s. I92.

$5 \quad$ M. Luter, $O$ świeckiej zwierzchności, w jakiej mierze należy być jej postusznym, dz. cyt., s. 196.

6 Por. J. Heckel, Lex charitatis: a Juristic Disquisition on Law in the Theology of Martin Luther, transl. and ed. G. G. Krodel, H. F. Falkenstein, J. A. Hiller, Grand Rapids 20IO, s. 22I.

7 Por. M. A. Failinger, P. R. Keifert, Making Our Home in the Works of God: Lutherans on the Civil ude of the Law, [w:] Christian Perspective on Legal Thought, ed. M. W. McConnell, R. F. Cochran, Jr., A. C. Carmella, New Heaven-London 200I, s. 390 . 
(I Kor I4, 40)" ". Ta konieczność istnienia i rozwoju prawa jest także uwarunkowana tym, że „świat ciągle się zmienia, pojawiają się nowe wyzwania dla Kościoła”.

Opisywaną koncepcję relacji związków wyznaniowych do prawa endogenicznego można nazwać modelem umiarkowanie przyjaznym prawu. W tym modelu prawo pełni rolę podrzędną wobec prawa Bożego i jest ono konieczne ze względu na istnienie i funkcjonowanie związku wyznaniowego w warunkach ziemskich.

\subsubsection{Koncepcja pełnej akceptacji prawa}

Kolejną koncepcją stosunku związków wyznaniowych do prawa jest jego forma reprezentowana przez Kościół katolicki i Kościoły prawosławne. Dla tych wspólnot ich własne prawo jest niezbywalną i integralną częścią systemu doktrynalno-moralnego.

Gdy chodzi o model katolicki, to akceptacja dla prawa w Kościele wyraża się w postawie wiernych wobec prawa, polegającej na szacunku wobec norm prawnych, rozumieniu znaczenia instytucji prawnych i świadomości hierarchii i wiernych co do roli i celów obowiązującego w Kościele prawa ${ }^{\mathrm{I}}$. Zwięźle wyraził to papież Jan Paweł II we Wstępie do kodeksu prawa kanonicznego z I983 r.:

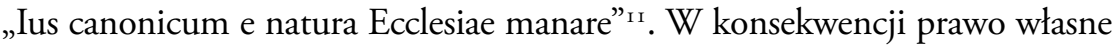
Kościoła jest „necessaria ut ecclesiastica communitas vigeat, crescat, floreat" ${ }^{{ }^{12}}$. Wprawdzie, jak można zauważyć, kultura prawna wyrażająca się przykładowo w poziomie prawodawstwa kościelnego, stopniu znajomości regulacji kanonicznych, a także w gorliwości przestrzegania przez wiernych oraz stosowaniu przez

8 Prawo zborowe Kościota Adwentystów Dnia Siódmego, dz. cyt., s. 9.

9 Prawo zborowe Kościota Adwentystów Dnia Siódmego, dz. cyt., s. 7.

Io Szerzej na ten temat zob. R. Sobański, Prawo kanoniczne a kultura prawna, „Prawo Kanoniczne” 35 (1992) nr I-2, s. I5-33; R. Sobański, Uwagi o miejscu prawa kanonicznego w kulturze prawnej, [w:] W kierunku religijności, red. B. Bejze, Warszawa I983, s. 268-282. Na temat pojęcia „kultura prawna” zob. np. K. Opałek, Zagadnienia teorii prawa $i$ teorii polityki, Warszawa 1986, s. 273-296.

II Preafatio, [w:] Codex Iuris Canonici auctoritate Ioannis Pauli PP. II promulgatus, dz. cyt., s. xx: „Prawo kanoniczne wynika z natury Kościoła”.

I2 Preafatio, [w:] Codex Iuris Canonici auctoritate Ioannis Pauli PP. II promulgatus, dz. cyt., s. xxx: „konieczne, aby wspólnota kościelna żyła, wzrastała i kwitła”. 
organy władzy kościelnej norm kanonicznych, nie dorównuje wspominanej deklaracji papieża Jana Pawła II odnośnie do szacunku dla prawa w Kościele ${ }^{\text {I3 }}$.

Z punktu widzenia prawosławia sprawa stosunku Kościoła prawosławnego w Polsce do prawa wewnętrznego jest trudna do jednoznacznego i precyzyjnego przedstawienia. Z jednej strony Kościoły prawosławne mają długą tradycję soborowego i synodalnego stanowienia prawa. Także ojcowie Kościoła w swoich pismach dotykali zagadnień prawnych związanych ze święceniami, administracją Kościelną, życiem wiernych Kościoła. Podobne zadanie wypełniali lokalni biskupi. Z drugiej strony koncepcja Kościoła w prawosławiu jest taka, że jest to par excellence duchowy i nadnaturalny organizm, którego główną zasadą istnienia i działania jest miłośćc ${ }^{14}$.

Kościół prawosławny, idąc za Janem Chryzostomem, stoi na stanowisku, że wypełnienie prawa nadanego przez Boga, co jest konieczne do zbawienia, może się odbywać także przez wypełnianie norm pochodzących z prawa ustanowionego przez człowieka ${ }^{\mathrm{I} 5}$. „Dogmatyczne sformułowania soborów posiadają prawdziwą i niezmienną ważność, której kanony jako takie nie mogą sobie rościć, bowiem określenia dogmatyczne dotyczą prawd wiecznych, kanony zaś zajmują się ziemskim życiem Kościoła, którego warunki ulegają ciągłym zmianom, a poszczególne sytuacje są nieskończenie zróżnicowane. Niemniej jednak pomiędzy kanonami a dogmatami Kościoła istnieje istotny związek prawo kanoniczne jest po prostu próbą zastosowania dogmatu w określonej sytuacji codziennego życia każdego chrześcijanina. Tak więc pośrednio kanony również stanowią część Świętej Tradycji”"

Według prawosławia wolność, którą przynosi Chrystus, nie oznacza bowiem, że człowiek może obywać się bez prawa i robić, co chce. W wolności człowiek ma kochać, a miłość nie zaprzecza prawu, lecz jest zastosowaniem prawa Bożego w życiu. Tak więc miłość i prawo nigdy nie są w opozycji do siebie. Co więcej, jakby na zasadzie sprzężenia zwrotnego, prawo pomaga w realizacji miłości. Harmonijne połączenie miłości i prawa nadaje instytucji kościelnej duchowy

I3 Zob. na ten temat P. Kroczek, The Art of Legislation: the Principles of Lawgiving in the Church, 2nd rev. ed., Kraków 2012, s. 7.

I4 Por. P. Rodopoulos, An Overviwe of Ortodox Canon Law, transl. W. J. Lillie, ed. G. D. Dragas, Rollinsford 2007, s. I3.

I5 Zob. Johannes Chrysostomus, Homilia XVI, [w:] Johannes Chrysostomus, Opera omnia quae exstant, accurante J. P. Migne, Parisiis I862, kol. 240-24I (Patrologiae cursus completus. Series Graeca, 57).

i6 K. Ware, Kościót prawostawny, dz. cyt., s. 229. 
charakter. Kościół, jako zorganizowana instytucja, jest zbudowany na fundamencie przykazania miłości, a więc każde prawo wewnętrzne stanowione w Kościele i dla Kościoła musi być umotywowane właśnie miłością. Prawo Kościoła w żaden sposób nie wyczerpuje i nie wypełnia religijnego życia człowieka, ale tworzy dla niego konieczną pomoc do tego, aby prowadził on życie duchowe, jakie powinni wieść wierni ${ }^{17}$.

Interesujące jest to, że prawo, zarówno w Kościele katolickim, jak i Kościołach prawosławnych postrzegane było i jest nadal, jako prawo specyficzne, o innym charakterze, innych celach i znaczeniu niż prawo stanowione z uwagi na cele czysto świeckie lub doczesne. Ten specjalny stosunek widoczny jest w nazwach zbiorów przepisów oraz jednostek redakcyjnych. $\mathrm{O}$ ile bowiem słowo lex było używane do nazwania prawa danego przez władcę świeckiego ${ }^{18}$, o tyle słowo canon (gr. אavóv oznacza w II grupie znaczeń: prawidło, model, wzór oraz normę ${ }^{19}$ ) zarezerwowane było dla prawa kościelnego, ustanowionego, aby regulować życie wiernego ${ }^{20}$.

Warto wiedzieć, że istniejące od początku w chrześcijaństwie ruchy antyjurydyczne można obserwować także współcześnie w Kościele katolickim² ${ }^{21}$. Ruchy te widzą w prawie element zbędny, a nawet szkodliwy dla wspólnoty wierzących. Według założeń tych ruchów wierni powinni się kierować nie nakazem prawnym, lecz samą miłością. Prawo w ich rozumieniu dotyczy porządku doczesnego, ziemskiego, a więc nie należy do istoty Kościoła ${ }^{22}$. W tych antyjurydycznych poglądach widać podobieństwo do argumentów Rudolfa Sohma.

I7 Por. P. Rodopoulos, An Overviwe of Ortodox Canon Law, dz. cyt., s. I6-I7.

I8 Zob. Leges, [w:] J. Sondel, Stownik tacinssko-polski dla prawników i historyków, Kraków 1997, s. 570-572.

I9 Zob. Kavóv, [w:] Stownik grecko-polski, red. A. Abramowiczówna, t. I, Warszawa 1958, s. 558 .

20 Por. P. Kroczek, The Art of Legislation..., dz. cyt., s. 30-32.

2I Por. R. Sobański, Prawo kościelne na tle trendów antyjurydycznych, „Collectanea Theologica" 43 (I973) fascicle IV, s. 37-46.

22 Na temat tych ruchów zob. R. C. Lara, Some Reflections of the Proper Way to Approach the Code of Canon Law, „CLSA Proceedings” 46 (1984), s. 27-28. Ruchy te mocno skrytykował papież Pius XII w Litterae encyclicae Mystici Corporis Christi, quod est Ecclesia, 29.06.1943, AAS 35 (1943), s. 193-248. 


\subsubsection{Koncepcja radykalnego związania z prawem}

Koncepcję radykalnego związku prawa i religii prezentują islam i judaizm. Prawo jest najbardziej istotnym komponentem islamskiej tożsamości i żydowskiej kultury ${ }^{23}$.

W islamie nastąpiło radykalne i bardzo ścisłe połączenie religijnej doktryny prawa i moralności. „Islam znacznie bardziej niż inne religie ma charakter porządku prawnego, który reguluje życie i postępowanie muzułmanina według nauk zawartych w Koranie i sunnie proroka. Prawo muzułmańskie jest totalitarne i rządzi każdą czynnością człowieka należącego do społeczności muzułmańskiej; każdy jego czyn, choćby najdrobniejszy i mało ważny, jest niejako przewidziany i sklasyfikowany przez skrupulatnych jurystów muzułmańskich. Islam ustanowił swój własny porządek sprawiedliwości, ustalając to, co jest słuszne i niesłuszne, to, co jest dobre i moralnie piękne, i co złe, moralnie brzydkie”24. Dla muzułmanina „żyć zgodnie z prawem znaczy żyć doskonale” ${ }^{25}$. Chodzi tu o prawo, które nie jest w ogóle oddzielane od religii czy moralności. O ile bowiem w koncepcji katolickiej i prawosławnej treści normatywne były budowane na podstawie prawd wiary i z nich bezpośrednio lub pośrednio wyprowadzane, o tyle w islamie regulacje prawne są niezbywalnym elementem doktryny, a nawet można powiedzieć - są doktryną.

Muzułmanie uznają prawo Mojżeszowe i prawa obowiązujące za prawo jako takie, choć nie za prawo obowiązujące muzułmanów. Jednakże wszystkie prawa i systemy religijne istniejące przed „Świętym Prorokiem” podlegają duchowemu przemijaniu i zanikowi. Jedynie „Prawo Świętego Proroka - Prawo Islamu - ma żyć i trwać aż po kres czasu" ${ }^{26}$.

Twórcą prawa według muzułmanów jest Bóg i u Boga znajduje się źródło prawa $^{27}$. Ogranicza to ingerencję człowieka w proces jego tworzenia. Zadaniem człowieka jest tylko interpretowanie i objaśnianie prawa ${ }^{28}$. „Allach zmazuje

23 Por. K. Greenawalt, Legal Interpretation. Perspectives from other Disciplines and Private Text, Oxford 20I0, s. I09.

24 J. Bielawski, Islam jako religia światowa, dz. cyt., s. 770; S. W. Witkowski, Wprowadzenie do prawa muzutmańskiego..., dz. cyt., s. I6.

25 J. Bielawski, Islam jako religia światowa, dz. cyt., s. 770.

26 Święty Koran, dz. cyt., s. 702, przyp. 1887.

27 Zob. Święty Koran, dz. cyt., s. 523, przyp. 1450.

28 Por. S. W. Witkowski, Wprowadzenie do prawa muzutmańskiego..., dz. cyt., s. 16. 
lub ustanawia wedle swojej woli i u Niego znajduje się źródło wszystkich przykazań" $^{29}$. Po pierwsze, Bóg ustanowił pewne prawa - prawa przyrody, które muszą być przestrzegane przez wszystkie stworzone przez Boga rzeczy, ożywione i nieożywione. Od posłuszeństwa wobec tych praw nie ma ucieczki. Po drugie, istnieją także inne prawa - szariat („droga prawa”) ${ }^{30}$. Zajmuje ono centralne miejsce w życiu muzułmanów, zarówno w wymiarze indywidualnym, jak i wspólnotowym i myśli islamskiej. Jest to prawo, które Bóg objawił po to, by kierować człowiekiem we wszystkich wymiarach - od życia rodzinnego poprzez sprawy gospodarcze po kult. Ma zatem charakter totalny. Określa to, co jest obowiązkiem wiernego (fard), i to, co jest zabronione ( haram). Do objawienia tych właśnie praw został powołany prorok Mahomet. „Powołany został w jałowej i nieurodzajnej dolinie Mekki i przekazał ludom najdoskonalsze i najbardziej kompletne Prawo” ${ }^{31}$. „Wraz z nadejściem Świętego Proroka Prawo Boże stało się pełne i doskonałe we wszystkich swoich najróżniejszych aspektach" ${ }^{32}$.

Prawo szariatu ma różne źródła. Jednym z nich jest Święty Koran, czyli słowo Boga. Ważnym źródłem jest tradycja (hadith), czyli krótkie opowieści z życia Proroka i jego towarzyszy - zachowania i obyczaje Proroka, a także jego nauczanie - wypowiedzi i osądy. Te opowieści ilustrują życie we wczesnej, idealnej wspólnocie wiernych. Stały się one podstawą sunny, czyli zbioru tradycji i prawnych orzeczeń.

Należy dodać, że o ile w radykalnej islamskiej myśli prawo to zajmuje naczelne miejsce, o tyle w innych nurtach w myśli islamskiej możliwe jest - przy poszanowaniu prawa szariatu - respektowanie również regulacji świeckich, szczególnie w zakresie gospodarczym, a niekiedy także w sferze rodzinnej ${ }^{33}$.

Radykalne związanie prawa i religii występuje także w judaizmie. Religijny charakter kultury, w tym także kultury prawnej judaizmu, wynika z wyprowadzania wszelkich norm: prawnych, moralnych i religijnych z religii Mojżeszowej ${ }^{34}$. Już sama struktura źródeł prawa żydowskiego jest rozbudowana hierarchicznie i pokazuje religijne pochodzenie prawa. Główne miejsce w tej

29 Święty Koran, dz. cyt., sura I3, wers 40.

30 Szeroko o tym zob. M. Kamali, An Introduction to Shari'ah, Kuala Lumpur 2006.

3I Swięty Koran, dz. cyt., s. IO.

32 Swięty Koran, dz. cyt., s. I385.

33 Por. Shari'ah, [w:] O. Leaman, L. Ali, Islam. The Key Concepts, dz. cyt., s. I22I23.

34 Por. R. Tokarczuk, Wspótczesne kultury prawne, dz. cyt., s. I67. 
strukturze zajmuje Tora, która jest „najważniejszą księgą judaizmu i podstawą żydowskiej świadomości” ${ }^{35}$. Jest ona złożona z dwóch części: Tory pisanej (Torah shebikh'tar) i Tory mówionej (Torah sheb'al. Peh). Powiązanie tych części Tory jest tak silne, że „Nie można zrozumieć Tory Pisanej bez Tory Ustnej” ${ }^{36}$.

Tora pisana, rozumiana w szerokim znaczeniu, to cała Biblia hebrajska, na którą składają się trzy zbiory pism: I. Tora - w znaczeniu wąskim - czyli Prawo (obejmująca Pięcioksiagg Mojżeszowy, tj. księgi: Rodzaju [Bereszit], Wyjścia [Szemot], Kapłańską [Wajikra], Liczb [Bamidbar], Powtórzonego Prawa [Dewarim]), 2. osiem ksiąg Proroków (Newiim), 3. jedenaście ksiąg Pism (Ketuwim).

Z kolei Tory mówionej nie wolno było spisywać. Zamiana słowa mówionego w formę pisaną doprowadziłaby bowiem do przekłamań w treści. Jednakże z powodu obawy, iż Tora mówiona nie będzie mogła być przekazywana - została ona spisana. W ten sposób powstała Tora mówiona spisana pod nazwą Miszna (Mishnah). Miszna zawiera normy prawne halakhah (z hebr. droga życia). Nazwa halakhah jest kluczowa dla kultury prawnej, używana jest w judaizmie na oznaczenie pojedynczych norm prawnych, ich zespołów, jak i całego systemu prawnego. Miszna zawiera także normy inne niż prawne. Są to normy należące do kultury zwane aggadah (z hebr. opowieść). Od Miszny należy odróżniać midrasze (midraszim), jako mniej znaczące kompilacje interpretacyjne Pięcioksięgu, pochodzące zarówno od rabinów, jak i osób świeckich. Analizy, omówienia, interpretacje i komentarze do Miszny zwane są Gemara (z hebr. gmore - studiowanie). Połączenie Miszna i Gemara złożyło się na Talmud zredagowany w wersji palestyńskiej i w wersji babilońskiej. Talmud jest ogromnym zbiorem opisowym i normatywnym, powstającym stopniowo poprzez rozwiązywanie aktualnych, konkretnych spraw życiowych Żydów.

Kultura prawna judaizmu ma bardzo rygorystyczny i mocno sformalizowany charakter, polegający na podporządkowaniu jej prawu Bożemu. Jednakże niektóre kultury prawne pozwalają na luźniejsze podejście do prawa. W całym niemal rozwoju jurysprudencji żydowskiej można dostrzec spór pomiędzy ortodoksyjnymi i liberalnymi interpretacjami prawa ${ }^{37}$.

35 Tora Pardes Lauder. Księga Pierwsza. Bereszit, red. S. Pecaric, przeł. E. Gordon, Kraków 200I, s. v.

36 Tora Pardes Lauder. Księga Pierwsza. Bereszit, dz. cyt., s. v.

37 Por. R. Tokarczuk, Wspótczesne kultury prawne, dz. cyt., s. I69. 


\subsubsection{Podsumowanie}

Trzeba powiedzieć, że znajomość doktrynalnego stosunku kościoła lub innego związku wyznaniowego do prawa jest bardzo ważna. Pozwala ona bowiem na odpowiednie podejście „zewnętrznych interpretatorów” do prawa wewnętrznego określonej wspólnoty. Gdy bowiem religijna wspólnota nie traktuje własnego prawa jako czegoś ważnego dla niej samej, z punktu widzenia religijnego czy nawet wyłącznie praktycznego, to może też ona nie przykładać większej wagi do takich elementów, jak zgodne z nauką prawa stanowienie prawa, promulgacja ustaw czy ich publikacja. Innymi słowy, standardy dotyczące prawa wewnętrznego związku wyznaniowego mogą być inne, niż to jest w przypadku prawa państwowego. $\mathrm{Ci}$, którzy zajmują się prawem religijnym, powinni na samym początku uwzględnić te różnice i nie oceniać tego prawa przez pryzmat własnego stosunku do prawa. W konsekwencji to, co wydaje się nie być aktem normatywnym z punktu widzenia prawa państwowego, z powodu formalno-technicznych uchybień, może być pełnoprawnym źródłem norm wewnętrznych w danej wspólnocie religijnej.

\subsection{Cel prawa}

Zasadniczo cel prawa endogenicznego kościołów i innych związków wyznaniowych jest bezpośrednio związany ze stosunkiem tych zrzeszeń do własnego prawa. Można wyróżnić cel religijny i cel społeczny.

\subsubsection{Cel religijny}

Zasadniczo celem religijnego prawa jest promowanie najważniejszych wartości religijnych, głównie tych wiążących wiernych z bóstwem. Prawo więc skupia się na trosce o osiągnięcie zbawienia przez wiernych ${ }^{38}$. Ten najważniejszy cel prawa doktryna chrześcijańska określa i normuje zarazem zwrotem salus animarum suprema lex (,zbawienie dusz najwyższym prawem”) ${ }^{39}$. W prawie kanonicznym Kościoła katolickiego ta reguła jest obecna na dwa sposoby.

38 Por. Wstęp, [w:] крк, s. 23.

39 Ivo Carnotensis, Epistula 6o, [w:] Ivo Carnotensis, Opera omnia, accurante J. P. Migne, Parisiis I854, kol. 74 (Patrologiae cursus completus. Series Latina, I62): „Cum ergo omnis institutio ecclesiasticarum legum ad salutem referenda sit 
Po pierwsze, implicite, jako zasada stanowiąca jakby podstawę dla wszelkiej działalności prawotwórczej, interpretacji prawa i jego aplikacji ${ }^{40}$. A po drugie, explicite, będąc częścią kan. 1752 obecnego kodeksu prawa kanonicznego ${ }^{41}$.

Z kolei według doktryny islamskiej człowiek w swej naturze jest słaby i nie potrafi sam odnaleźć drogi postępu duchowego. „Allach pragnie ulżyć waszemu brzemieniu, człowiek bowiem stworzony został słabym" ${ }^{42}$. Te słabości ludzkie są jedynym powodem, dla którego Bóg objawił Prawo. Ma ono pomagać człowiekowi w dotarciu do wzniosłego celu. Dlatego Prawo nie jest klątwą, lecz pomocą i błogosławieństwem ${ }^{43}$.

\subsubsection{Cel socjologiczny}

Oczywisty z natury, ale także stwierdzony przez prawo polskie wyznaniowy charakter religijnych zrzeszeń (por. art. I ust. I i 2 u.g.w.s.w.) nie zaprzecza ich socjologicznemu charakterowi ani go nie pomniejsza. Kościoły i związki wyznaniowe są społecznościami i z innymi zbiorowościami dzielą pewne cechy ${ }^{44}$. Dlatego też nie można nie uwzględniać socjologicznego celu prawa.

Takim socjologicznym celem prawa wewnętrznego może być chęć nadania określonej struktury organizacyjnej kościołowi lub związkowi wyznaniowemu i zapewnienia działania tej grupy. Wówczas cel ten wiąże się z zasadą prawniczą ubi societas ibi ius. Zgodnie z tym prawidłem każda społeczność ludzka, także ta o charakterze religijnym, aby istnieć, działać i osiągać własne cele, musi podlegać jakiemuś reżimowi prawnemu, czyli przykładowo posiadać własne wewnętrzne regulacje. Oczywiście, jak już wspomniano, nie musi to być prawo

animarum [...]”. („Dlatego też każda instytucja praw kościelnych musi odnosić się do zbawienia dusz") (przeł. P. Kroczek).

40 Por. M. Wijlens, Salus animarum suprema lex: Mercy as a Legal Principle in the Application of Canon Law, „The Jurist” 54 (I994), s. 588.

4I Kan. I752: „W sprawach przeniesienia należy stosować przepisy kan. I747, z zachowaniem kanonicznej słuszności i mając przed oczyma zbawienie dusz, które zawsze winno być w Kościele najwyższym prawem” („In causis translationis applicentur praescripta canonis 1747 , servata aequitate canonica et prae oculis habita salute animarum, quae in Ecclesia suprema semper lex esse debet”).

42 Święty Koran, dz. cyt., sura 4, wers 29.

43 Zob. Święty Koran, dz. cyt., s. 200, przyp. 593.

44 Por. R. Sobański, Ustawa kościelna - „ordinatio rationis” czy „ordinatio fidei?”, "Collectanea Theologica” 48 (I978) fascicle I, s. 28. 
stanowione. Regulacje te mogą istnieć jako prawo zwyczajowe. Jednakże ustanowienie prawa wewnętrznego na podstawie istniejących w praktyce norm, zmienia tylko ich charakter, a nie normatywną treść.

Dzięki prawu wewnętrznemu może nastąpić uporządkowanie takich elementów związku wyznaniowego, jak: nazwa tego zrzeszenia, teren działania i siedziba władz, cele działalności oraz formy i zasady ich realizacji, organy wewnętrzne zrzeszenia oraz sposób ich powoływania i odwoływania, zakres kompetencji oraz tryb podejmowania przez nie decyzji, źródła finansowania zrzeszenia, sposób reprezentowania go na zewnątrz oraz zaciągania zobowiązań majątkowych, sposób nabywania i utraty członkostwa w zrzeszeniu oraz prawa i obowiązki członków, sposób powoływania, odwoływania oraz kompetencje osób duchownych i wreszcie sposób rozwiązania zrzeszenia i przeznaczenie pozostałego majątku (por. art. 32 ust. 2 u.g.w.s.w.). Wymienione elementy są ważne dla istnienia i sprawnego funkcjonowania religijnego zrzeszenia.

Oczywiście nie można wykluczyć, że celem istnienia prawa wewnętrznego jest chęć formalnego podporządkowania się państwowym regulacjom, w tym przypadku wymogowi posiadania statutu, w celu rejestracji danego kościoła lub innego związku wyznaniowego.

\subsection{Zakres prawa}

\subsubsection{System prawa}

Prawo endogeniczne kościołów i innych związków wyznaniowych nie rości sobie pretensji do konkurowania z prawem państwowym, gdy chodzi o zakres regulacji. Ma bowiem na celu regulację życia członków wspólnoty głównie w wymiarze religijnym. W tym zaś zakresie, co do zasady, świeckie państwo nie czuje się kompetentne.

Materia regulowana prawem wewnętrznym związku wyznaniowego jest zatem specyficzna i dotyczy ich działalności religijnej. Oznacza to, że zakres prawa zależy od treści dogmatyczno-moralnych kościoła lub związku wyznaniowego. „Zewnętrzny interpretator” nie może więc oczekiwać jakiejś kompleksowości czy pełności systemowej od prawa wewnętrznego kościołów czy związków wyznaniowych, a jednocześnie musi uwzględnić, że prawo wewnętrzne wymaga dopełnienia $\mathrm{w}$ regulacjach zewnętrznych, czyli w prawie państwowym. 
Nie można jednak powiedzieć, że prawo związków wyznaniowych nie jest „predystynowane do pełnienia funkcji państwowego systemu prawnego” 45 . Funkcje prawa bowiem, niezależnie od jego pochodzenia, mogą być identyczne lub przynajmniej zbliżone. Innymi słowy - nie ma różnicy w funkcjach, lecz w obszarze działania prawa.

Prawo polskie nie narzuca wewnętrznych rozwiązań żadnej grupie religijnej, lecz pozwala na daleko posuniętą autonomię w tym zakresie. Ustawodawca wprost stwierdza, że kościoły i inne związki wyznaniowe są niezależne od państwa przy wykonywaniu swoich funkcji religijnych, ale także, że ich działalność podlega ochronie prawnej, w granicach określonych w ustawach (art. II ust. I i ust. 2 u.g.w.s.w.). Tego wolnościowego podejścia nie osłabiają regulacje polskie, które wymagają od związków wyznaniowych podania określonych danych rejestracyjnych, czy też ustawowe wymagania odnośnie do treści statutu związków, które mają podlegać rejestracji (zob. art. 32 ust. 2 u.g.w.s.w.).

Zakres regulacji zawartych w endogenicznym prawie zrzeszeń religijnych jest więc bardzo ograniczony, a to oznacza, że przepisy wewnętrzne nie tworzą kompletnego prawnego systemu. Nie jest to jednak konieczne. Dla kościołów i innych związków wyznaniowych znaczenie ma nie tylko prawo powstałe wewnątrz tych wspólnot. Także prawo powstałe poza nimi, czyli prawo pochodzące od prawodawcy świeckiego, odgrywa pewną rolę w życiu wspólnoty wiernych.

Punktem wyjścia jest sytuacja wiernego, który działa i jest podmiotem praw i obowiązków w obu strukturach społecznych - w kościele lub związku wyznaniowym i w państwie. Wierny i jednocześnie obywatel jest zaangażowany w życie jednej i drugiej społeczności, podlega obu systemom prawnym. Wierny ma obowiązek praktykować swoją religię, co wypełnia także poprzez zachowanie praw związku wyznaniowego, do którego należy (por. kan. 209\$2 KРК), ale ma być on także lojalny wobec państwa, co łączy się z obowiązkiem przestrzegania prawa Rzeczypospolitej Polskiej (art. 83 Konstytucji RP).

45 A. Tunia, Recepcja prawa wewnętrznego zwiąków wyznaniowych w prawie polskim, Lublin 20I5, s. 44 . 


\subsubsection{Odesłania do prawa państwowego}

Konsekwencją ograniczoności zakresu regulacji jest to, że prawo wspólnot religijnych często posiłkuje się prawem państwowym, uznając kompetencje państwa w wielu obszarach. Jest to zjawisko przejmowania przepisów państwowych na forum religijnym, czyli włączania ich jako swoich do endogenicznego porządku prawnego.

W przypadku Kościoła katolickiego chodzi o „kanonizację” poszczególnych przepisów, jak to obecnie ma miejsce na mocy kan. $22 \mathrm{KPK}$, nakazującego, aby ustawy państwowe, do których odsyła prawo kościelne, zachować w prawie kanonicznym, o ile nie są przeciwne prawu Bożemu i o ile prawo kanoniczne czegoś innego nie zastrzega. W tym bowiem przypadku odesłanie do prawa egzogenicznego przez normę kanoniczną zasadniczo odbywa się na dwa sposoby.

Po pierwsze, niektóre przepisy prawa ustanowione przez prawodawcę świeckiego stają się normami prawa kościelnego i mają być zachowane z mocą prawa Kościoła, tak jakby były utworzone przez prawodawcę kościelnego. W ten sposób podlegają one kanonizacji i nadaje się im wartość prawa własnego, wewnętrznego. Przykładowo w prawie kanonicznym zasadniczo zgodnie z prawem cywilnym liczy się przedawnienie (kan. I97, kan. I268, kan. I492 \$ I KPK), określa warunki umów (kan. I290 KPK) oraz ugody, kompromisu czy sądu polubownego (kan. I7I4 KPK).

Po drugie, poprzez normę z kan. 22 przyznaje się normom z systemu prawa cywilnego skuteczność na forum kanonicznym. Nie są one włączane do systemu kanonicznego, jedynie ich skutki mają być uznane przez prawo kanoniczne. Przykładowo prawo kanoniczne uznaje dokonane w oparciu o prawo świeckie usamodzielnienie małoletniego (kan. IOs \$ I KPK), adopcję (kan. ІІо кPK) i jej konsekwencje, gdy chodzi o pochodzenie dziecka (kan. $877 \$ 3 \mathrm{KPK}$ ), zaręczyny (kan. IO62 \ I KPK) ${ }^{46}$.

W tym kontekście należy przywołać instytucję nomokanonów (nomocanones). Kościół katolicki używał tego terminu od pierwszej połowy viıI w., szczególnie na Wchodzie. Nomokanony to przepisy (kolekcje przepisów lub ich kompilacje) regulujące życie Kościoła wydane przez władcę świeckiego i kościelnego ${ }^{47}$.

46 Por. R. Sobański, Kanon 22, [w:] J. Krukowski, R. Sobański, Komentarz do Kodeksu Prawa Kanonicznego, dz. cyt., s. 77-78.

47 Zob. Nomokanon, [w:] J. Sondel, Stownik tacinsko-polski..., dz. cyt., s. 66o; R. Potz, Nomokanon, [w:] Lexikon des Kirchenrechts, Hrsg. S. Haering, H. Schmitz, Freiburg-Basel-Wien 2004, kol. 679-680. 
Istnieje pogląd, że także współcześnie Kościół katolicki powinien w wielu wypadkach traktować regulacje państwowe jako własne. W przypadku nomokanonów następuje szersze uznanie kompleksowych regulacji za własne - przykładowo wszystkie regulacje dotyczące postępowania w przypadku molestowania seksualnego małoletnich ${ }^{48}$. Byłaby to zatem kompleksowa recepcja prawa państwowego na forum kanonicznym dokonana intencjonalnie i dobrowolnie przez Kościól.

Kanonizacja przepisów, choć bez takiego określenia tego prawnego zjawiska, występuje także w prawie wewnętrznym związków wyznaniowych. Jej przypadki można pogrupować.

Po pierwsze, kanonizacja następuję en bloc w danym obszarze podlegającym regulacji państwowej. Prawo wewnętrzne Kościoła Ewangelicko-Metodystycznego „kanonizuje” prawo polskie w zakresie tworzenia nowego instytutu lub zakładu związanego z „szeroko rozumianą służbą bliźniemu” (art. 77 ust. 2 PWKE-M). Gminy wyznaniowe żydowskie zebrane w Związku sprawy majątkowe chcą regulować przez adresowaną do nich ustawę, a także przez przepisy powszechnie obowiązującego prawa (art. 48 ust. 2 Pwwwż). Pragmatyka Służbowa Kościoła Ewangelicko-Augsburskiego nakazuje w kilku miejscach zastosowanie prawa polskiego w określonym zakresie: ksiag finansowych ( $\$$ I59 ust. 3 PS), ubezpieczeń społecznych ( $\$ 205$ ust. 2 PS), prawa pracy (\$2 246 ust. I Ps).

Po drugie, kanonizacja obejmuje konkretną ustawę. Kościół Zielonoświątkowy odwołuje się w art. 36 ust. 7 Prawa Wewnętrznego do kodeksu cywilnego jako źródła norm w przypadku likwidacji organizacji zielonoświątkowej lub w fundacji.

Po trzecie, prawo związków wyznaniowych może przejmować nie przepisy, ale wyłącznie skutki prawne. Przykładowo, Pragmatyka Służbowa Kościoła Ewangelicko-Augsburskiego w Rzeczypospolitej Polskiej z dnia 28 listopada I999 r. w $\$$ I45 stwierdza, że Kościół nie przeprowadza postępowania rozwodowego. Jeżeli małżeństwo zostało rozwiązane wyrokiem sądu powszechnego, przyjmuje do wiadomości istniejący stan rzeczy i pozwala, już zgodnie z prawem wewnętrznym, zawrzeć nowe małżeństwo.

Po czwarte, w Statucie Wewnętrznym Polskiego Autokefalicznego Kościoła Prawosławnego istnieje „kanonizacja” zagranicznego prawa. W $\$ 44$ ust. I tego

48 Por. Ch. Donahue, A Crisis of Law? Reflections on the Church and the Law Over the Centuries, „The Jurist” 65 (2005), s. 30. 
aktu normatywnego nakazuje się, aby jednostki organizacyjne tego Kościoła znajdujące się poza granicami Polski działały na podstawie statutu, przy zachowaniu przepisów prawa tego państwa, na którego terytorium mają siedzibę.

\subsection{Konsekwencje nieprzestrzegania prawa}

Wydaje się, że w celu lepszego zrozumienia endogenicznego prawa związków wyznaniowych trzeba poruszyć zagadnienie konsekwencji niezachowania norm pochodzących z tego prawa.

W warunkach polskich kościoły i związki wyznaniowe nie mają do dyspozycji, w przeciwieństwie do państwa, środków przymusu bezpośredniego, aby utrzymywać swoich wiernych w karności i dyscyplinie. Kary, które może stosować kompetentny przełożony kościelny, zasadniczo wiążą się wyłącznie z pozbawieniem osoby dobra duchowego lub doczesnego - bono spirituali vel temporali (kan. $13 \mathrm{I} 3 \$ 2 \mathrm{KPK})^{49}$.

$\mathrm{Z}$ racji tego, że regulacje służą religii, a ta zawsze jest związana z określoną moralnością należy zauważyć, że niekiedy normy prawa religijnego mogą obowiązywać ad cuplam. Oznacza to, że ich niewypełnienie będzie skutkowało grzechem, czyli wiązało się z zaciągnięciem kary wewnętrznej - duchowej. Inaczej mówiąc - skutki obowiązywalności norm leżą w formum internum. Oczywiście, prawo religijne zwykle skutkuje odpowiedzialnością na forum externum, a więc niezachowanie normy skutkuje ad poenam. Jest to wynik tego, że prawo kościołów i innych związków wyznaniowych jest prawem społeczności i nie zawsze ma fundamenty w prawie nadprzyrodzonym.

Powyższe rozróżnienie jest wyraźnie widoczne w przypadku prawa kanonicznego. Każda ustawa prawa kanonicznego powszechnego zawsze wiąże w sumieniu swojego adresata. Natomiast ustawa partykularna wiąże jedynie karą zewnętrzną - „non obligare ad culpam, sed tantum ad poenam” ${ }^{\circ}$, o ile oczywiście nie zawiera prawa kanonicznego powszechnego lub prawa Bożego.

Podobne rozumienie połączenia sankcji zewnętrznej i wewnętrznej występuje u mariawitów. W Ustawach Zgromadzenia Sióstr Maryawitek Nieustającej

49 Por. can. 2215 CIC: „Poena ecclesiastica est privatio alicuius boni ad delinquentis correctionem et delicti punitionem a legitima auctoritate inflicta”.

50 G. Michiels, Normae generales iuris canonici, vol. I, Parisiis-Tornaci-Romae I949, s. 314-315: „Nie obowiązuje co do winy, lecz co do kary” (przeł. P. Kroczek). 
Adoracyi Ubłagania napisano: „Z Reguły obowiązują pod grzechem ciężkim tylko śluby i to, co się tyczy wyboru i złożenia Przełożonej Generalnej. Te rzeczy, które się tyczą zwyczajów, ceremonii porządku i t. p. [sic!] nie obwiązują przez się pod grzechem"sI. Natomiast w podstawowych regulacjach dotyczących Związku Maryawitów Nieustającej Adoracyi Ubłagania tę kwestię ujęto w ten sposób: „Ustawy osób należących do tego Związku, wyjąwszy tych - co śluby czynią, w tem - co dotyczy ślubów - nie obowiązują pod grzechem"s2.

W metodyzmie natomiast nie mówi się w kontekście łamania prawa wewnętrznego o winie w sensie ad culpam, lecz w formie ad poenam. Nie ma winy wewnętrznej, jest jednak sankcja zewnętrzna. Za nieprzestrzeganie prawa grożą określone sankcje dyscyplinujące, czy to w formie upomnienia, zawieszenia prawa do korzystania z niektórych przywilejów i obowiązków wynikających z przynależności do wspólnoty aż po rozwiązanie ostateczne, jakim jest wykluczenie z grona członków tej wspólnoty. W odniesieniu do duchownych ostatecznym rozwiązaniem jest najpierw zawieszenie w prawach i obowiązkach duchownego, a następnie wyłączenie ze stanu duchownego.

Trzeba ponadto zauważyć, że zdecydowana większość regulacji prawa kanonicznego zawiera normae imperfetae, co oznacza, że brak w nich sankcji karnych. A jeżeli już w kanonach dotyczących przestępstw prawodawca zawarł jakieś kary, to często są one nieoznaczone. Ich wymiar zależy od swobodnej decyzji sędziego kościelnego (zob. np. kan. I328 \$ I, kan. 1365, kan. I369 KPK). Wynika to z zasady mówiącej, że żadne prawo powszechne, wiążąc w sumieniu swojego adresata, nigdy nie może być prawem czysto karnym (leges mere poenalis). Może zaś nim być prawo partykularne.

Z kolei bardzo radykalne powiązanie religii i prawa w islamie skutkuje tym, że prawo nabiera charakteru obowiązku religijnego, którego przekroczenie jest zawsze naganne i często wiąże się z karą. Kara może być wynikiem przekroczenia praw natury oraz naruszenia prawa szariatu ${ }^{53}$. Podstawową zasadą prawną islamu jest wolnośćs ${ }^{4}$. Człowiek, będąc wolny, może wybierać między posłuszeństwem i nieposłuszeństwem wobec tych praw i ewentualnie ponosić

5I Ustawy Zgromadzenia Sióstr Maryawitek Nieustającej Adoracyi Ubłagania, [w:] Dzieto Wielkiego Mitosierdzia dla świata..., dz. cyt., rozdział I, nr I.

52 Statut Związku Maryawitów Nieustającej Adoracyi Ubłagania, [w:] Dzieto Wielkiego Mitosierdzia dla świata..., dz. cyt., III Obowiązki, s. 320.

53 Zob. Święty Koran, dz. cyt., s. 423, przyp. I243.

54 Por. J. Bielawski, Islam jako religia światowa, dz. cyt., s. 77I. 
konsekwencje ich odrzuceniass. Czyny w prawie islamskim dzielone są na klasy i należą do następujących kategorii:

I. istotne obowiązki, których wypełnianie jest wynagradzane, a zaniedbanie karane (fard, wadżib),

2. obowiązki zalecane, lecz nieistotne, których wypełnianie jest nagradzane, lecz zaniedbanie nie jest karane (mandub),

3. czynności prawnie i moralnie obojętne (dżäiz, mubah),

4. czyny zabronione i karalne (haram $)^{56}$.

Ogólnie mówiąc, konsekwencje nieprzestrzegania norm prawnych pochodzących z prawa wewnętrznego związków wyznaniowych różnią się od konsekwencji nieprzestrzegania prawa państwowego. Członkowie tych religijnych zrzeszeń zwykle muszą liczyć się z wewnętrzną sankcją, która może także towarzyszyć sankcji zewnętrznej, typowej dla prawa świeckiego. W konsekwencji prawo religijne, choć nie ma tak szerokich możliwości penalizacyjnych jak prawo państwowe, zarówno, co do zakresu kar, jak i ich nieuchronności, oddziaływać może mocniej na adresatów norm niż prawo świeckie.

\subsection{Kultura prawna jako matrix prawa}

Przy omawianiu prawa kościołów i innych związków wyznaniowych należy również zwrócić uwagę na to, że każde prawo jest stanowione w określonej kulturze prawnej, która jest swoistym matrixem. Ta kultura prawna zwykle wpływa na ustawodawcę religijnego, czerpie on z niej celowo lub nieintencjonalnie ${ }^{57}$. Może się to przejawiać w przyjmowanych rozwiązaniach prawnych, instytucjach prawnych czy także w technikach legislacyjnych.

W przypadku prawa powszechnego Kościoła katolickiego, czyli tego stanowionego na szczeblu centralnym, tj. Stolicy Apostolskiej, kulturą prawną będzie kultura śródziemnomorska. Jest ona odmienna od polskiej kultury prawnej, która stanowi raczej oryginalną mieszankę lokalnych kultur prawnych, z przewagą kultury prawnej francuskiej czy szerzej romańskiej. Pozostałe

55 Zob. Święty Koran, dz. cyt., s. 723, przyp. I94.

56 Por. J. Bielawski, Islam jako religia światowa, dz. cyt., s. 783 .

57 Wielość kultur prawnych przedstawia syntetycznie R. Sobański, Prawo kanoniczne a kultura prawna, dz. cyt., s. 16-18. 
kościoły i związki wyznaniowe będące obiektem analizy czerpią z polskiej kultury prawnej, szczególnie w zakresie techniki legislacyjnej.

Tę prawidłowość potwierdza w jakimś stopniu to, że kodeks prawa kanoniczego zawiera kanony, natomiast prawa wewnętrzne innych kościołów czy związków wyznaniowych są dzielone na jednostki redakcyjne, takie jak paragrafy, artykuły. Wyjątkiem jest tylko Prawo wewnętrzne Kościoła polskokatolickiego, które także posiada kanony. Oczywiście nazwa podstawowych jednostek redakcyjnych jest częściowym potwierdzeniem tego, do jakiego źródła tradycji odwołują się poszczególne kościoły lub związki wyznaniowe. Mocniejszym argumentem za tezą o odmienności tych systemów prawnych byłby argument z odmienności instytucji prawnych tych systemów - ich ukształtowania i działania. Jednakże, żeby to stwierdzić, trzeba by przeanalizować te instytucje, porównując je.

To stwierdzenie musi prowadzić do konkluzji, że prawo kanoniczne, po pierwsze, będzie różniło się od prawa endogenicznego pozostałych kościołów i innych związków wyznaniowych, po drugie, będzie trudniejsze do interpretowania dla prawników operujących w kręgu polskiej kultury prawnej.

\subsection{Podmioty władzy ustawodawczej}

Pozostałe endogeniczne źródła norm prawnych kościołów i innych związków wyznaniowych można zidentyfikować przez wskazanie podmiotów władzy ustawodawczej w tych zrzeszeniach.

\subsubsection{Kościół katolicki}

Gdy chodzi o Kościół katolicki, to katalog podmiotów władzy ustawodawczej jest obszerny. Można podzielić go na dwa podkatalogi.

Do prawodawców mających władzę ustawodawczą w Kościele katolickim o zasięgu powszechnym zalicza się: Biskupa Rzymskiego (kan. 33I, kan. 333 $\$$ I KРК), Kolegium biskupów, razem z Biskupem Rzymskim, jako głową (kan. 336 крк), Synod biskupów, lecz tylko na mocy władzy delegowanej (kan. 343 КРК), kongregacje rzymskie, lecz tylko na mocy specjalnego papieskiego mandatu ${ }^{58}$.

58 Pastor bonus, art. I8. 
Do prawodawców partykularnych zalicza się: Konferencje biskupów w przypadkach określonych prawem powszechnym lub szczególnym postanowieniem Stolicy Apostolskiej (kan. $455 \$$ I KPK), Synody partykularne (plenarne, prowincjalne) dla podległych sobie terytoriów (kan. 439-446 KРК), biskupów diecezjalnych, działających na synodach diecezjalnych lub poza nimi (kan. 38I \$I, kan. 466 KPK), wszystkich zrównanych z biskupami diecezjalnymi w prawie (kan. 38I \$ 2, zob. kan. 368 KPK), wyższych przełożonych kleryckich instytutów zakonnych na prawie papieskim i kleryckich stowarzyszeń życia apostolskiego na prawie papieskim, którzy posiadają przynajmniej zwyczajną władzę wykonawczą (kan. $596 \rrbracket$ I i $\$ 2$ KPK, zob. kan. I34 $₫$ I, kan. $586 \rrbracket$ I, kan. 593 KPK). Do prawodawców statutowych, czyli takich, którzy mogą wydawać prawo regulujące życie wewnętrzne określonych społeczności zaliczyć można: kapituły (katedralne i kolegiackie), instytuty życia konsekrowanego, stowarzyszenia wiernych, uczelnie.

\subsubsection{Polski Autokefaliczny Kościół Prawosławny}

W przypadku Polskiego Autokefalicznego Kościoła Prawosławnego jego statut uchwala Sobór Lokalny (art. 6 ust. 4 u.s.p.p.a.k.p.), który jest zwierzchnią władzą tego Kościoła ( $\$ 4$ ust. I SWPAKP). Ustawodawstwo polskie nazywa ten organ także Soborem Krajowym Kościoła (art. 6 ust. 3 u.s.p.p.a.k.p.). Ma on również kompetencje do uchwalania innych praw niż statut ( $\$ 2$ pkt 3 SWPAKP).

Jednakże w statucie tego Kościoła z 1995 r. kompetencję do uchwalania statutu przyznano wprost i wyłącznie Świętemu Soborowi Biskupów ( $\$ 8$ lit. $n$ SWPAKP). Jest to więc niezgodne z ustawą z I99I r., a przecież „Postanowienia Statutu nie mogą być sprzeczne z niniejszą ustawą” (art. 6 ust. 3 u.s.p.p.a.k.p.).

Wprawdzie przepis przejściowy tejże ustawy stanowi, że „Do czasu zwołania Soboru Lokalnego, Statut Wewnętrzny Kościoła jest uchwalany przez Święty Sobór Biskupów" (art. 52), lecz wydaje się, że było błędem uchwalanie statutu w brzmieniu, który jakby sanuje stan przejściowy, lecz nie przyznaje kompetencji do stanowienia podstawowego aktu normatywnego Soborowi Lokalnemu. Święty Sobór Biskupów natomiast - według statutu wewnętrznego Kościoła - może uchwalać statut parafialny, statut duszpasterstwa wojskowego oraz inne nieprzewidziane w statucie regulaminy, instrukcje i przepisy ( $\$ 8$ lit. $n$ SWPAKP). 


\subsubsection{Kościół Ewangelicko-Reformowany w Rzeczypospolitej Polskiej}

Najwyższą władzę Kościoła Ewangelicko-Reformowanego stanowi Synod, który jest „najwyższym zgromadzeniem przedstawicieli Jednoty Ewangelicko-Reformowanej" (art. 50 PWKE-R). Uchwala on ustawę o nazwie Prawa Wewnętrzne (art. 2 ust. 2 u.s.p.k.e-r.), a także regulaminy kościelne (art. 54 pkt a PWKE-R).

\subsubsection{Kościół Ewangelicko-Augsburski w Rzeczypospolitej Polskiej}

W przypadku Kościoła Ewangelicko-Augsburskiego głównym podmiotem ustawodawczej władzy dla Kościoła jest Synod Kościoła. Organ ten jest powołany do uchwalania i zmian we wszystkich prawach kościelnych $(\$ 58$ ust. 2 ZPWKE-A, $\$ 64$ pkt 4 ZPWKE-A, $\$ 266$ PSKE-A). Na ten ustawodawczy organ wskazuje także prawo państwowe, a mianowicie Ustawa z dnia I3 maja I984 r. o stosunku Państwa do Kościoła Ewangelicko-Augsburskiego w Rzeczypospolitej Polskiej w art. I ust. I.

Inny organ mogący stanowić prawo to Rada Synodalna ( $\$ 65$ ust. I pkt 5 ZPWKE-A). Nie jest pewne, czy jakieś kompetencje ustawodawcze można przypisać także Synodowi Diecezjalnemu (zob. $\$ 9$ ust. I lit. i Regulaminu Diecezjalnego w związku z $\$$ Io ust. I pkt 3 oraz $\$$ II ust. 5 ZPWKE-A).

\subsubsection{Kościół Ewangelicko-Metodystyczny w Rzeczypospolitej Polskiej}

W Kościele Ewangelicko-Metodystycznym najwyższą władzą jest Konferencja Doroczna (art. 26 PWKE-M). Do niej należy „podejmowanie uchwał w zakresie ogólnych spraw kościelnych oraz uchwalanie ważniejszych przepisów kościelnych" (art. 40 pkt a PWKE-M). 


\subsubsection{Kościół Starokatolicki Mariawitów w Rzeczypospolitej Polskiej}

W przypadku Kościoła Starokatolickiego Mariawitów głównym podmiotem władzy prawodawczym jest Synod (art. 2 ust. I u.s.p.k.s.m.). Synod jest zwierzchnią władzą Kościoła (art. III \ I SKSM).

Innymi organami prawodawczymi są: Kapituła Generalna (art. IV $\$ 3$ oraz art. v $\$ 5$ SKSM) i Rada Kościoła (art. $3 \$$ I pkt d oraz art. $3 \$ 7$, art. viII $\$$ IO SKSM). Zakres kompetencji tych dwóch organów, co do zakresu regulacji, które mogą stanowić, jest rozłączny. Statut nakazuje jednak, aby prawo uchwalone przez Radę Kościoła było zatwierdzane przez Kapitułę (art. XIV $\$ 2$ sKSM).

Najniższym szczeblem władz prawodawczych są władze parafialne, czyli Zebranie Parafialne. Ich zakres nie jest jednak w statucie jasno określony (art. XI $₫ 5$ pkt f sKsm). W praktyce ogranicza się do wewnętrznych spraw gospodarczo-organizacyjnych ${ }^{59}$.

\subsubsection{Kościół Katolicki Mariawitów w Rzeczypospolitej Polskiej}

W Kościele Katolickim Mariawitów zwierzchnią władzą Kościoła jest Kapituła Generalna (art. 2 ust. I u.s.p.k.m.; $\$$ I7 ust. I sKKM; zob. $\$$ I9 ust. I SKKM), która może stanowić prawo dla tego związku wyznaniowego.

\subsubsection{Wschodni Kościół Staroobrzędowy nieposiadający hierarchii duchownej w Rzeczypospolitej Polskiej}

Zwierzchnią władzę w tym Kościele sprawuje Ogólnopolski Sobór ( $\$ 4$ swks, art. 3 r.s.p.w.k.s.). Do jego kompetencji należy także uchwalanie statutu i jego zmian ( $\$$ IO pkt 6 swKs). Zgodnie ze statutem uchwały w tych sprawach podlegają zatwierdzeniu przez Urząd do spraw Wyznań ( $\$$ io pkt 6 sw $\mathrm{Ks}$ ).

Trzeba dodać, że uchwały w sprawach wiary i moralności są zawsze autonomiczną decyzją Soboru. Natomiast te uchwały Soboru, które nie dotyczą wiary

59 Zob. Wywiad z biskupem M. L. Jabłońskim (archiwum prywatne autora, sygn. KSM/I). 
i moralności, przekazuje się do ogłoszenia Naczelnej Radzie Staroobrzędowców, która przed dokonaniem ogłoszenia upewnia się, czy Urząd do spraw Wyznań nie podnosi sprzeciwu wobec treści uchwały ( $\$$ I4 SwKs, art. 3 r.s.p.w.k.s.).

\subsubsection{Muzułmański Związek Religijny w Rzeczypospolitej Polskiej}

Ustawa z dnia 2I kwietnia 1936 r. o stosunku Państwa do Muzułmańskiego Związku Religijnego w Rzeczypospolitej Polskiej nie określa jasno kompetencji organów ustawodawczych dla tego związku wyznaniowego. Jedynie w art. 3 stanowi ona, że „Zwierzchnią władzę w Muzułmańskim Związku Religijnym w Rzeczypospolitej Polskiej sprawuje Mufti Muzułmański w Rzeczypospolitej Polskiej z pomocą Najwyższego Kolegium Muzułmańskiego”.

Statut Muzułmańskiego Związku Religijnego z 1936 r. w $\$ 46$ upoważnia Wszechpolski Kongres Muzułmański, lecz tylko w zakresie uchwalania szczegółowych przepisów w przedmiocie wakufów. Kongres może działać w tym zakresie na wniosek Najwyższego Kolegium Muzułmańskiego. Także statut tego związku może być zmieniany i uzupełniany przez uchwały Kongresu (\$55 SMZRI936).

W porównaniu z tymi regulacjami Statut Muzułmańskiego Związku Religijnego z 2009 r. jaśniej określa podmiot władzy i stanowi, że Wszechpolski Kongres Muzułmańskiego Związku Religijnego jest „Najwyższym organem stanowiącym Muzułmańskiego Związku Religijnego” (art. 9 ust. I SMZR2009).

\subsubsection{Karaimski Związek Religijny w Rzeczypospolitej Polskiej}

Najwyższą władzą u karaimów jest, według statutu, Krajowy Zjazd Delegatów Dżymatów ( $\$ 4$ SKzR). Ma on kompetencje prawodawcze ( $\$$ I2 lit. c i e). Natomiast zgodnie z ustawą "Zwierzchnią władzą Karaimskiego Związku Religijnego jest Hachan Karaimski w Rzeczypospolitej Polskiej [...]" (art. 3 ust. 3 u.s.p.k.z.r.). Jest to rozbieżność, jednakże problem ten nie był rozstrzygany, gdyż na stanowisku hachana w całym okresie po II wojnie światowej jest wakat. Niemniej, zgodnie z $\$ 23$ statutu tego związku wyznaniowego hachan jest z urzędu lub z wyboru członkiem Zarządu Karaimskiego Związku 
Religijnego. W okresie uchwalania ustawy przez sejm istniała tendencja nadawania większych uprawnień jednoosobowemu przywódcy, natomiast statut opracowywano w latach siedemdziesiątych ubiegłego wieku, w okresie odchodzenia od takich tendencji i przy uwzględnieniu faktycznego braku hachana ${ }^{60}$.

\subsubsection{Kościół Polskokatolicki w Rzeczypospolitej Polskiej}

„Najwyższą władzą prawodawczą w Kościele jest Synod Ogólnopolski, który ma pełnię władzy jurysdykcyjnej” (art. 4 ust. 2 u.s.p.k.p.; kan. 93 PWKP). Synod ten uchwala Prawo Wewnętrzne tego Kościoła (art. 4 ust. I u.s.p.k.p.; kan. 96 pkt b PWKP), a także inne prawa (kan. Io $\$$ I PWKP). Nie jest do końca zrozumiałe powtarzanie trzykrotne tej samej normy w różnych miejscach prawa wewnętrznego.

Uprawnienie prawodawcze ma również Rada Synodalna tego Kościoła. Jej kompetencje reguluje przede wszystkim kan. I49 \ I PWKP: „Sprawy szczegółowe, nie objęte przepisami niniejszego Prawa Wewnętrznego, normuje Rada Synodalna”. Prawo Kościoła precyzyjnie stanowi, że kompetencje te są ograniczone do zmian dotyczących przepisów liturgicznych (kan. IO8 pkt h PWKP) oraz uchwalania regulaminów: Sądu Biskupiego (kan. IO8 PWKP), Komisji Rewizyjnej (kan. 139), Funduszu Kościelnego (kan. I48 PWKP).

\subsubsection{Kościół Adwentystów Dnia Siódmego w Rzeczypospolitej Polskiej}

Najwyższym organem, także o kompetencjach prawodawczych, jest Zjazd Kościoła (art. 4 ust. I u.s.p.k.a.d.s.; art. II SKADs). Inna nazwa tego Zjazdu to „Synod Krajowy Kościoła” (art. 4 ust. I u.s.p.k.a.d.s.). Tą nazwą jednak nie posługuje się statut.

Wydaje się, że kompetencje prawodawcze może mieć także: Rada Kościoła, Rada Wydziału, Rada Generalnej Konferencji (art. I3 ust. I sKADs), aczkolwiek te kompetencje nie są jasno wyartykułowane ani określone.

60 Zob. List S. Pileckiego (Przewodniczącego Zarządu Karaimskiego Związku Religijnego) z dnia I4.IO.20I5 r. (archiwum prywatne autora, sygn. KZR/I). 


\subsubsection{Kościół Chrześcijan Baptystów w Rzeczypospolitej Polskiej}

Głównym prawodawcą dla Kościoła Chrześcijan Baptystów jest Krajowa Konferencja Kościoła. Do jej właściwości należy w szczególności uchwalanie Zasadniczego Prawa Wewnętrznego Kościoła (art. 3 u.s.p.k.ch.b) i innych powszechnie obowiązujących przepisów prawnych Kościoła (art. 35 ust. I pkt I ZРWкснв). Przykładowo organ ten uchwala regulamin Komisji Rewizyjnej (art. 46 ust. 7 ZРWкснв).

Rada Kościoła może ponadto ustanawiać akty normatywne: Regulamin Rady Kościoła i Regulamin Prezydium Rady Kościoła, statuty dla jednostek organizacyjnych nabywających osobowość prawną na podstawie ustawy (art. 42 pkt I3 i pkt I4 ZРWкСнв).

Podmiotem władzy ustawodawczej jest także Konferencja Okręgu (art. 27 ust. I pkt 2 ZPWKCHB).

\subsubsection{Związek Gmin Wyznaniowych Żydowskich}

Prawodawcą dla Związku Gmin Żydowskich jest Walne Zebranie Związku Gmin. Do zakresu działania należy uchwalanie Prawa wewnętrznego i jego zmian w porozumieniu z Radą Religijną (art. 32 ust. I pkt I Pwwwż), regulaminu organizacji i przebiegu obrad Walnego Zebrania Związku Gmin (art. 32 ust. I pkt 3 Pwwwż).

Jednakże Ustawa z dnia 20 lutego 1997 r. o stosunku Państwa do gmin wyznaniowych żydowskich w Rzeczypospolitej Polskiej stanowi w art. 3 ust. 2, że ustawodawcą własnego prawa wewnętrznego dla gmin żydowskich jest walne „zebranie Związku Gmin w porozumieniu z Radą Religijną Związku Gmin”.

Rada Religijna Związku Gminy jest najwyższą władzą Związku Gmin w okresach pomiędzy Walnymi Zebraniami Związku Gmin (art. 34 ust. I Pwwwż), może także uchwalać przepisy regulujące działalność Wspólnoty, które niezastrzeżone są dla innych władz Wspólnoty (art. 36 pkt 8 Pwwwż). 


\subsubsection{Kościół Zielonoświątkowy w Rzeczypospolitej Polskiej}

W Kościele Zielonoświątkowym najwyższym organem prawnym Kościoła jako całości jest Synod (art. 7 ust. I PWKz). Do jego kompetencji należy „stanowienie prawa kościelnego” oraz „nowelizacja i zmiany Prawa Wewnętrznego” (art. 2 u.s.p.k.z.; art. 7 ust. 2 pkt I i art. 45 PWKz).

\subsection{Specyficzne elementy racjonalności prawodawcy religijnego}

Jurysprudencja polska pokazuje całe spektrum cech, którymi powinien odznaczać się ustawodawca. Te cechy składają się na koncepcje „racjonalnego ustawodawcy" ${ }^{61}$. Oczywiście jest to tylko wyidealizowany model, do którego asymptotycznie powinien, przynajmniej w założeniach, zbliżyć się każdy prawodawca. Założenie o racjonalności podmiotu stanowiącego prawo jest niezbędne dla dokonującego wykładni ${ }^{6_{2}}$. Powinno być ono stosowane ostrożnie ${ }^{63}$ i poddane krytyce i obaleniu w sytuacji absurdalności wyniku wykładni prawa ${ }^{64}$.

Jednakże prawo związków wyznaniowych ze względu na swą specyfikę wymaga specyficznego modelu racjonalnego ustawodawcy. Poza kompetencjami wspólnymi dla wszystkich ustawodawców, takimi jak, przykładowo: posiadanie właściwiej wiedzy z zakresu prawa i jego stanowienia, wykładni i stosowania, wiedzy z zakresu materii, która ma być regulowana, ustawodawca w związku wyznaniowym powinien także wypełniać trzy postulaty: I) osobistej wiary, 2) członkostwa w związku, dla którego jest prawodawcą i piastowania w nim innych urzędów oraz 3) zachowania ortodoksji doktrynalno-moralnej charakterystycznej dla danego związku wyznaniowego.

6I Por. E. Kustra, Racjonalny ustawodawca. Analiza teorioprawna, Toruń I980; S. Wronkowska, The Rational Legislator as a Model for the Real Lawmaker, [w:] Polish Contribution to the Theory and Philosophy of Law, ed. Z. Ziembiński, Amsterdam I987, s. I53; L. Nowak, Interpretacja prawnicza. Studium z metodologii prawoznawstwa, Warszawa 1973, s. 39.

62 Por. L. Nowak, Interpretacja prawnicza..., dz. cyt., s. 54-57.

63 Por. R. Sobański, Kanon I7, [w:] J. Krukowski, R. Sobański, Komentarz do Kodeksu Prawa Kanonicznego, dz. cyt., s. 70.

64 Por. L. Morawski, Co może dać nauce prawa postmodernizm?, Toruń 200I, s. 55. 


\subsubsection{Osobista wiara}

Po pierwsze, religijny prawodawca powinien być człowiekiem wierzącym, czyli posiadającym osobisty stosunek do bóstwa - osobistą wiarę (fides qua creditur). Oczywiście weryfikacja tego postulatu jest problematyczna.

Sprawa osobistej wiary prawodawcy jest rzadko poruszana w literaturze kanonistycznej. Nieliczni autorzy skłaniają się jednak do tego, że wiara ta jest konieczna do wypełnienia prawodawczego zadania: „Każdy akt kościelnej władzy rządzenia, oczywiście także władzy ustawodawczej (zob. kan. I35 $₫$ I) jest inspirowany i wypływa z wiary. Dlatego ustawę kościelną określa się terminem ordinatio fidei ${ }^{65}$. Oznacza to, że postulat, aby prawodawca kościelny był człowiekiem wiary ${ }^{66}$, a przynajmniej - w wersji minimalistycznej - brał wiarę pod uwagę w swojej pracy jako czynnik warsztatowy ${ }^{67}$, ma głębokie uzasadnienie. Analiza funkcjonowania tego postulatu komplikuje się szczególnie mocno w przypadku, gdy prawodawcą jest podmiot zbiorowy, np. sobór, synod, kapituła czy kongres.

\subsubsection{Członkostwo w społeczności wiernych}

Konsekwencją osobistej wiary osoby jest zwykle jej formalne członkostwo w danym związku wyznaniowym. Wydaje się, że takie członkostwo to warunek konieczny tego, aby dana osoba mogła pełnić rolę prawodawcy dla wspólnoty religijnej. Analizując postulat członkostwa, trzeba powiedzieć, że pożądana jest sytuacja, w której podmiot posiadający kompetencję prawodawczą aktywnie wypełnia także i inne (pozaprawodawcze) funkcje w danym związku, przykładowo w sferze doktrynalno-moralnej, organizacyjnej, zarządzającej. Tak jest w przypadku urzędu biskupa w Kościele katolickim (kan. 38I $\$$ I, kan. 466 KРК). Przez to zaangażowanie ma on możliwość lepiej odpowiadać na potrzeby wspólnoty poprzez stanowione regulacje.

65 P. Kroczek, Termin "fides" $w$ optyce prawodawcy i interpretatora na przyktadzie KPK I983, [w:] Wiara a prawo: między wolnościa a postuszeństwem, red. P. Kroczek, Kraków 2013, s. I43 (Annales Canonici. Monographiae, I); szerzej zob. R. Sobański, Ustawa kościelna..., dz. cyt., s. 27-35.

66 Por. P. Kroczek, The Art of Legislation..., dz. cyt., s. 79-80.

67 Por. R. Sobański, Kościót - prawo-zbawienie, Katowice 1979, s. 357-359. 
W przypadku zbiorowych organów stanowiących, takich jak: Synod Kościoła ( $\$ 58$ ust. 2 ZPWKE-A, art. 2 ust. I u.s.p.k.m.) czy Kapituła Generalna (art. 2 ust. I u.s.p.k.m.), obowiązek członkostwa w religijnym zrzeszeniu oraz zajmowanie kluczowych urzędów czy piastowanie godności w danym związku wyznaniowym są wprost określone przez prawo (zob. \$ 59 ZWP).

\subsubsection{Ortodoksja doktryny i stanowionego prawa}

Kolejnym postulatem, który można skierować w stronę ustawodawcy religijnego, jest postulat wiernego zachowania przez niego ortodoksji. Od prawodawcy wymaga się, aby znał treści wiary i podzielał zapatrywania doktrynalne wspólnoty religijnej, z którą czuje łączność poprzez wiarę (fides quae creditur).

Rozwiązania prawne, jakie prawodawca przyjmuje w swoich ustawach, muszą być całkowicie zgodne z tym, co wyznaje i głosi dany kościół lub inny związek religijny. Nie może być rozdźwięku pomiędzy wymaganiami prawa a wymaganiami wiary. Oczywiście nie muszą się one zupełnie pokrywać. Niekiedy prawo związku wyznaniowego dotyczy spraw, które nie podlegają ocenie doktrynalnej.

\subsubsection{Uwaga krytyczna}

$\mathrm{Z}$ punktu widzenia założeń pozytywizmu prawnego niezrealizowanie pierwszego postulatu, czyli osobistej wiary prawodawcy, nie łączy się z aprioryczną nieobowiązywalnością przepisów przezeń ustanowionych. Obiektywnie rzecz biorąc, prawo ustanowione dla wspólnoty wierzących przez prawodawcę ateistę jest prawem.

Podobnie jest z drugim z postulatów. Prawodawcą dla związku wyznaniowego może być np. państwo. Wprawdzie w tej sytuacji nie można twierdzić, że jest to prawo endogeniczne, jednakże nie ma to wpływu na moc obowiązującą tego prawa wobec członków wspólnoty.

Natomiast niewypełnienie przez prawodawcę wewnętrznego trzeciego postulatu powoduje, że prawo religijne nie obwiązuje. Nie można bowiem nakazywać czegoś, co jest sprzeczne z wiarą. Norma wiary zawarta - w przypadku wszystkich badanych kościołów i innych związków wyznaniowych - w księgach objawionych jest najważniejsza. Gdyby prawodawcą prawa nieortodoksyjnego 
był organ zewnętrzny wobec związku wyznaniowego, to choć formalnie prawo takie byłoby wiązące, to członkowie związku wyznaniowego nie powinni, z racji religijnych, przestrzegać tego prawa.

\section{8. Źródła prawa związków wyznaniowych}

$\mathrm{Na}$ wstępie rozważań na temat źródeł prawa związków wyznaniowych należy poczynić uwagę, że klasyczny podział na źródła powstania lub istnienia prawa (fontes oriundi seu essendi) i źródła poznania prawa (fontes cognoscendi) obecnie nie jest potrzebny. Współcześnie źródła istnienia prawa są bowiem jednocześnie źródłami jego poznania ${ }^{68}$.

\subsubsection{Nazwy aktów normatywnych i ich publikatory}

Źródła prawa polskiego państwowego są określone, nazwane i zhierarchizowane w rozdziale III Konstytucji RP w art. 87-94. Trudność pojawia się przy próbie ustalenia tych źródeł we wspólnotach religijnych.

Pierwszym źródłem prawa wewnętrznego kościoła lub innego związku wyznaniowego, do którego powinien sięgnąć przedstawiciel doktryny prawa polskiego, chcąc poznać prawo własne tej organizacji, jest statut danego związku wyznaniowego. $\mathrm{Na}$ jego istnienie i nazwę wskazuje zwykle ustawa regulująca stosunek państwa do tej organizacji. Dokument ten, jako załącznik do wniosku o rejestrację, muszą przedstawić kościoły i inne związki religijne, które się o nią ubiegają. Ustawa o gwarancjach wolności sumienia i wyznania w art. 32 ust. 2-5 określa ramy treści normatywnej statutu. Można w nim znaleźć, poza kluczowymi dla identyfikacji religijnego zrzeszenia (art. 32 ust. 2 pkt I u.g.w.s.w.), również regulacje dotyczące organów tego związku - sposobu ich powoływania i odwoływania, zakresu kompetencji oraz trybu podejmowania decyzji (art. 32 ust. 2 pkt 4 u.g.w.s.w.), sposób reprezentowania na zewnątrz oraz zaciągania zobowiązań majątkowych (art. 32 ust. 2 pkt 7 u.g.w.s.w.), a także inne regulacje dotyczące jednostek organizacyjnych związku wyznaniowego (art. 32 ust. 3 u.g.w.s.w.). Polska ustawa posługuje się terminem „statut”, lecz

68 Por. R. Sobański, Teoria prawa kościelnego, Warszawa I992, s. 83. 
dokument ten może mieć inny tytuł, przykładowo: „prawo wewnętrzne” czy też „zasadnicze prawo wewnętrzne”.

Wyjątkiem od wskazanej reguły konieczności posiadania statutu jest Kościół katolicki. Ma to uzasadnienie historyczne oraz faktyczne poprzez to, że Kościół ten posiada dwie fundamentalne ustawy, czyli „kodeksy”, które pełnią funkcję statutu.

O ile ustawy regulujące stosunek kościoła lub innego związku wyznaniowego zwykle odwołują się do określonego aktu normatywnego wewnętrznego danego religijnego zrzeszenia, dla przykładu, Ustawa z dnia I3 maja I994 r. o stosunku Państwa do Kościoła Ewangelicko-Augsburskiego w Rzeczypospolitej Polskiej w art. I ust. 2 przywołuje Zasadnicze Prawo Wewnętrzne tego Kościoła, o tyle w przypadku Kościoła katolickiego nie jest przywoływany określony akt normatywny, lecz ogólnie jest mowa o „własnym prawie” (art. 2 u.s.p.k.k).

Bywa, że kościoły i inne związki wyznaniowe mają inne pozastatutowe regulacje. Ich identyfikacja jest prosta wtedy, gdy odwołują się do nich statuty. Przykładowo Zasadnicze Prawo Wewnętrzne Kościoła Ewangelicko-Augsburskiego w Rzeczypospolitej Polskiej odwołuje się w $\$$ 2I ust. I i $\$$ I8 ust. 2 pkt 5 do Pragmatyki Służbowej Kościoła Ewangelicko-Augsburskiego w Rzeczypospolitej Polskiej, a w $\$ 54$ do Regulaminu Diecezjalnego Kościoła Ewangelicko-Augsburskiego w Rzeczypospolitej Polskiej.

Gdy statut wprost nie odwołuje się do innych aktów normatywnych, należy je zidentyfikować $\mathrm{w}$ inny sposób. W polskim systemie prawnym można to czynić przez odwołanie się do nazw tych dokumentów, np. „ustawa”, „,rozporządzenie”. Jednakże w przypadku kościołów lub innych związków wyznaniowych stosowane nazewnictwo może identyfikację przeprowadzaną w oparciu o kryterium nazwy poważnie utrudnić. Przykładowo, w Kościele katolickim nazwy używane na określenie podstawowych źródeł prawa, jak ustawy, są bardzo różne. Wprawdzie prawo kanoniczne zna termin lex („ustawa”) (np. kan. 6 $\$$ I pkt 2, kan. 7, kan. $8 \$ 2$ KРK), lecz funkcję ustawy może także pełnić dokument o nazwie decretum generale („dekret ogólny”) (kan. 29, kan. 30, kan. 3I $\$$ I, kan. 32, kan. $33 \$$ I, kan. $455 \$$ I KPK). Niestety, sprawę komplikuje fakt, że równoznacznie z lex i decretum generale używa się ponadto takich nazw, jak praescriptum, constitutio, norma, ius ${ }^{69}$, a nawet, wbrew samemu kodeksowi

69 Por. R. Sobański, Teoria prawa kościelnego, dz. cyt., s. 44. 
(kan. $34 \$ \mathrm{I})$ - instrukcja (instructio) ${ }^{70}$. W Kościele Ewangelicko-Augsburskim natomiast używa się, na oznaczenie ustawy, terminów: „prawo”, „pragmatyka” oraz „regulamin”.

Przy ustalaniu źródła norm prawnych należy uwzględnić autentyczne wykładnie dokonywane przez kompetentne organy związków wyznaniowych. W przypadku Kościoła katolickiego, zgodnie z $\$$ I kodeksu łacińskiego oraz kan. 1498 kodeksu dla katolickich Kościołów wschodnich, w sposób autentyczny ustawy interpretuje prawodawca oraz ten, komu on zlecił władzę autentycznego interpretowania. Organem powołanym do wypełnienia tej funkcji jest Papieska Rada do spraw Tekstów Prawnych (Pontificia Commissio Codici Iuris Canonici Authentice Interpretando $)^{71}$. Decyzje tej dykasterii stanowią źródło prawa na równi z ustawą, której dotyczą ${ }^{72}$.

Prawo powszechne Kościoła, a także jego wykładnie autentyczne publikowane jest w „Acta Apostolicae Sedis”, czyli w oficjalnym publikatorze Stolicy Apostolskiej. Z kolei kanoniczne prawo partykularne, czyli prawo obowiązujące lokalnie w ramach jednostek administracyjnych Kościoła (najczęściej będzie to prawo diecezjalne) jest publikowane przez własny organ prasowy tych jednostek. Organy te mają różne nazwy. Dla przykładu, archidiecezja krakowska posiada organ prasowy pt. „Notificationes e Curia Metropolitana Cracoviensi”, archidiecezja białostocka - „Wiadomości Kościelne Archidiecezji w Białymstoku”, diecezja bielsko-żywiecka - „Pismo Urzędowe Diecezji Bielsko-Żywieckiej”, diecezja chełmska - „Orędownika Diecezji Chełmińskiej”, diecezja ełcka - „Kronikę Urzędową Diecezji Ełckiej”, diecezja rzeszowska „Zwiastowanie”.

Gdy chodzi o inne kościelne osoby prawne, takie jak instytuty zakonne, to praktyka związana z publikacją prawa jest rozmaita. Przykładowo, Zakon Braci Mniejszych Konwentualnych (Ordo Fratrum Minorum Conventualium), czyli franciszkanie wydają „Commentarium Ordinis Fratrum Minorum

70 Por. R. Sobański, Kan. 34, [w:] J. Krukowski, R. Sobański, Komentarz do Kodeksu Prawa Kanonicznego, dz. cyt., s. 93; P. Kroczek, Ocena instrukcji „Dignitas connubii” z perspektywy sztuki legislacji, „Prawo Kanoniczne” 58 (2015) nr I, s. 94-I09.

7I Pastor bonus, art. I54-158 oraz Joannes Paulus PP. II, Litterae apostolicae motu proprio Recognitio Iuris Canonici Pontificia Commissio Codici Iuris Canonici authentice interpretando constituitur, 2.0I.1984, AAs 76 (1984), s. 433-434.

72 Polskie tłumaczenie interpretacji autentycznych w porządku systematycznym zob. Kodeks Prawa Kanonicznego. Komentarz, red. P. Majer, wyd. pol. na podst. wyd. hiszp., Kraków 2011, s. I319-1329. 
Conventualium", w którym umieszcza się m.in. dekrety generalne będące ustawami dla zakonu lub jego prowincji. Z kolei, Zakon Kaznodziejski (Ordo Praedicatorum), czyli dominikanie nie mają specjalnego regularnie wydawanego organu prasowego. Gdy chodzi o ogłaszanie praw konstytucji i zarządzenia kapituł generalnych, to zgodnie z Ksiegga konstytucji i zarzadzeń Braci Zakonu Kaznodziejów ${ }^{73}$ dokonuje się to przez wydanie ich w ,aktach kapituł generalnych lub w inny sposób, jaki określi kapituła” (nr 282 кKizвzk). Gdy zaś chodzi o prawa ustanawiane przez kapitułę prowincjalną, wydawane są one „drukiem w języku ojczystym, względnie łacińskim" (nr 363 ккіzвzк).

W Kościele Ewangelicko-Augsburskim autentycznej wykładni praw i przepisów kościelnych dokonuje Rada Synodalna, a zatwierdza tę wykładnię Synod Kościoła ( $\$ 65$ ust. I pkt 8 zPWKE-A). Wykładnie publikowane są na stronie internetowej Kościoła ${ }^{74}$. Kościół ten nie ma oficjalnego dziennika urzędowego, lecz stosuje się okólniki, które Rada Synodalna zwykle rozsyła lub udostępnia obowiązującą wersję kościelnych przepisów prawnych na stronie internetowej Kościoła (\$ 65 ust. 3 ZPWKE-A).

Prawa wewnętrzne Polskiego Autokefalicznego Kościoła Prawosławnego „są umieszczane i publikowane" w organie prasowym Kościoła ( $\$ 5$ ust. 2 SWPAKP). Jest nim „organ urzędowy” zatytułowany „Wiadomości Polskiego Autokefalicznego Kościoła Prawosławnego" ( $\$ 45$ SWPAKP).

U karaimów „interpretacja przepisów religijnych wyznania karaimskiego” (\$25 lit. c) należy do kompetencji hachana, lecz w statucie nie podano, gdzie są publikowane. Kompetencja ta nie obejmuje statutu, gdyż ten „nie zawiera stricte przepisów religijnych"75. W związku z tym nie wydano żadnych autentycznych wykładni przepisów prawnych. Akty prawne nie są publikowane w oficjalnym publikatorze ${ }^{76}$.

Muzułmański Związek Religijny umieszcza komunikaty, informacje i oświadczenia w czasopiśmie „Muzułmanie Rzeczypospolitej” lub w „Przeglądzie Tatarskim”, zaś akty normatywne na oficjalnej stronie internetowej związku.

73 Księga konstytucji i zarządzeń Braci Zakonu Kaznodziejów, w tłumaczeniu na język polski, wyd. 6, Poznań 2003 [dalej: ккizbzk].

74 Wyktadnie autentyczne przepisów prawa kościelnego, http://bik.luteranie.pl/files/ Prawo/wykladnie.pdf (I2.0I.20I6).

75 List S. Pileckiego (Przewodniczącego Zarządu Karaimskiego Związku Religijnego) z dnia I4.IO.20I5 r. (archiwum prywatne autora, sygn. KZR/I).

76 Zob. List S. Pileckiego (Przewodniczącego Zarządu Karaimskiego Związku Religijnego) z dnia I4.IO.20I5 r. (archiwum prywatne autora, sygn. KZR/I). 
W Kościele polskokatolickim prawo wewnętrzne przyznaje kompetencje do autentycznego wykładania przepisów Synodowi Ogólnopolskiemu, a w okresie między synodami wykładnia przepisów niniejszego prawa należy do Rady Synodalnej (kan. Io $\$ 2$ PWKP).

W Kościele Chrześcijan Baptystów dokonywanie wykładni przepisów Zasadniczego Prawa Wewnętrznego i innych przepisów powierzono Krajowej Konferencji Kościoła (art. 35 ust. I pkt 3 ZPWKCHB).

Kościół Metodystyczny ma czasopismo „Pielgrzym Polski”, które jest oficjalnym organem prasowym Kościoła. Ukazuje się od $1926 \mathrm{r}$. W tym organie został opublikowany Statut Kościoła Metodystycznego w Polskiej Rzeczypospolitej Ludowej uchwalony przez 55. Sesję Konferencji Ogólnej obradującej w lipcu 1978 r. i zatwierdzony przez władze państwowe. Jeżeli chodzi o akty prawne dotyczące spraw organizacyjnych, to są one ogłaszane także w formie okólników rozsyłanych do poszczególnych parafii lub też zamieszczane na oficjalnej stronie internetowej Kościoła. Wykładni przepisów w odniesieniu do prawa metodystycznego uchwalanego w Polsce dokonuje Rada Kościoła. Zgodnie z Konstytucją Zjednoczonego Kościoła Metodystycznego, będącą integralną częścią Ksieggi Dyscypliny, przepisy dotyczące struktury Kościoła oraz zasady proceduralne interpretuje Biskup Konferencji, do której przynależy dana Konferencja Doroczna.

Kościół Starokatolicki publikuje swoje dokumenty w czasopiśmie „Mariawita".

U zielonoświątkowców przygotowywanie wykładni przepisów prawa wewnętrznego należy do właściwości Komisji Praw Kościelnych (art. Io ust. 2 PWKZ).

Statut Kościoła Adwentystów nie wymienia organu dokonującego wykładni jego przepisów. Jednakże Prawo zborowe stanowi, że „Z wszelkimi pytaniami dotyczącymi funkcjonowania zborów czy interpretacji Prawa zborowego urzędnicy zboru, jego przywódcy i wyznawcy powinni zwracać się do lokalnej diecezji. Jeśli konsultacja nie przyniesie obustronnego zrozumienia, sprawę należy skierować do unii, na której terenie znajduje się diecezja" 77 . Poprzez „unię” należy, zgodnie z wyjaśnieniem podanym w Prawie zborowym, rozumieć Kościół działający w Rzeczypospolitej, Zarząd Kościoła lub Radę Kościoła ${ }^{78}$. Brakuje jednoznaczności w przestawieniu kompetencji w tej regulacji.

77 Prawo zborowe Kościota Adwentystów Dnia Siódmego, dz. cyt., s. I4.

78 Zob. Prawo zborowe Kościota Adwentystów Dnia Siódmego, dz. cyt., s. I4, przyp. I. 
Jeżeli chodzi o praktyczną możliwość dotarcia do źródeł prawa wewnętrznego kościołów i innych związków wyznaniowych, to są one zbierane i wydawane przez zewnętrznych badaczy ${ }^{79}$. Niestety, takie wydawnictwa szybko się dezaktualizują, zdarza się też, że nie zawsze są zrobione starannie ${ }^{80}$.

Oczywiście istnieje możliwość dotarcia do tych aktów poprzez oficjalne strony internetowe kościołów lub innych związków wyznaniowych - o ile dane religijne zrzeszenie dopuszcza publikację swojego prawa w formie elektronicznej. Jednakże teksty pozyskane w ten sposób muszą być traktowane z dużą ostrożnością, zwłaszcza gdy chodzi o ich aktualność.

Pewnym rozwiązaniem jest skorzystanie z „prawa do informacji publicznej” (art. 2 ust. I ustawy o dostępie do informacji publicznej ${ }^{81}$ ) czy odwołanie się do Rozporządzenia Ministra Spraw Wewnętrznych i Administracji z dnia 3I marca 1999 r. w sprawie rejestru kościołów i innych związków wyznaniowych $^{82}$. W $\$$ IO ust. 4 tego rozporządzenia stanowi się, że odpisy i wyciągi z ksiag rejestrowych (co zgodnie $\mathrm{z} \$ 4$ tego rozporządzenia obejmuje także statuty) mogą być wydawane osobom mającym w tym interes prawny, zaś prawo do przeglądania, zgodnie z ust. 2, przysługuje każdemu.

W tym miejscu trzeba przychylić się do podnoszonego w literaturze przedmiotu postulatu, aby $-\mathrm{z}$ uwagi na doniosłość prawną kluczowych aktów normatywnych związków wyznaniowych cieszących się własną ustawą - związki te rozważyły publikowanie ich w formie drukowanej oraz stworzenie łatwego doń dostępu. To umożliwiałoby w szczególności analizę przepisów wewnętrznych pod względem ich zgodności z ustawami oraz pozwoliłaby na śledzenie nowelizacji ${ }^{83}$.

79 Por. W. Wysoczański, M. Pietrzak, Prawo Kościołów i związków wyznaniowych nierzymskokatolickich $w$ Polsce, dz. cyt.; Prawo wewnętrzne nierzymskokatolickich związów wyznaniowych w Polsce. Wybór aktów prawnych, oprac. P. Borecki, C. Janik, Warszawa 20I2; M. Winiarczyk-Kossakowska, Ustawy III Rzeczypospolitej o stosunku państwa..., dz. cyt.

80 Przykładowo Statut Kościoła Adwentystów Dnia Siódmego w Rzeczypospolitej Polskiej z dnia I2 czerwca 2008 r. umieszczony w zbiorze M. Winiarczyk-Kossakowska, Ustawy III Rzeczypospolitej o stosunku państwa..., dz. cyt., w chwili wydania książki był już nieaktualny.

8I Ustawa z dnia 6 września 200 r. o dostępie do informacji publicznej (tekst jedn. Dz.U. z 2016 r. poz. 1764).

82 Dz.U. Nr 38, poz. 374.

83 Por. T. J. Zieliński, Prawo wewnętrzne gmin wyznaniowych żydowskich w Polsce a normy ustawowe, „Studia z Prawa Wyznaniowego” I4 (20II), s. 44. 
Proponuje się ponadto rozważanie celowości „promulgacji aktów prawa wewnętrznego" nie tylko w oficjalnych organach urzędowych tych religijnych zrzeszeń, lecz także umieszczanie ich w jakimś publikatorze państwowym. Wskazuje się, że takie działanie byłoby instrumentem weryfikacji cechy spójności tych przepisów z ustawami ${ }^{84}$. Nota bene takie rozwiązanie było niekiedy stosowane w okresie II Rzeczypospolitej ${ }^{85}$. Do powyżzzego postulatu trzeba koniecznie wprowadzić pewne zastrzeżenie i zmodyfikować go. Postulat nie może bowiem obejmować „promulgacji” aktów normatywnych związków wyznaniowych w państwowym organie urzędowym. Skoro leges instituuntur cum promulgantur („ustawy powstają z chwilą ich promulgowania”) ${ }^{86}$, to muszą tej czynności dokonać zgodnie z własnym prawem same związki wyznaniowe. Stanowienie prawa i jego promulgowanie w czasie i w formie przez siebie wybranej należy uznać za element autonomii i niezależności związku wyznaniowego. W zmodyfikowanym postulacie chodzi wyłącznie o popularyzację tych dokumentów w państwowej formie urzędowej, która stanowi solidne źródło informacji.

84 Por. T. J. Zieliński, Prawo wewnętrzne gmin wyznaniowych żydowskich w Polsce a normy ustawowe, „Studia z Prawa Wyznaniowego” I4 (20II), s. 44.

85 Statut Muzułmańskiego Związku Religijnego w Rzeczypospolitej Polskiej z dnia 26 sierpnia 1936 r., który stanowi załącznik do rozporządzenia Rady Ministrów z dnia 26 sierpnia I936 r. o uznaniu Statutu Muzułmańskiego Związku Religijnego w Rzeczypospolitej Polskiej (Dz.U. poz. 517); Statut Karaimskiego Związku Religijnego w Rzeczypospolitej Polskiej z dnia 26 sierpnia 1936 r., który stanowi załącznik do rozporządzenia Rady Ministrów z dnia 26 sierpnia 1936 r. o uznaniu Statutu Karaimskiego Związku Religijnego w Rzeczypospolitej Polskiej (Dz.U. Nr 72, poz. 518); Statut Wschodniego Kościoła Staroobrzędowego, nie posiadającego hierarchji duchownej z dnia 22 marca 1928 r. który stanowi załącznik do rozporządzenia Rady Ministrów z dnia 22 marca 1928 r. o uznaniu statutu Wschodniego Kościoła Staroobrzędowego, nie posiadającego hierarchji duchownej (M.P. Nr 2IO); Statut wewnętrzny Św. Polskiego Autokefalicznego Kościoła Prawosławnego z dnia Io grudnia 1938 r. który stanowi załącznik do rozporządzenia Rady Ministrów z dnia Io grudnia 1938 r. o uznaniu Statutu Wewnętrznego Polskiego Autokefalicznego Kościoła Prawosławnego (Dz.U. $\mathrm{Nr}$ I03, poz. 679). W każdym z tych przypadków chodziło o uznanie statutu przez władzę państwową.

86 Por. Decretum magistri Gratiani, II40 r., [w:] Corpus Iuris Canonici, editio Lipsiensi secunda post Ae. L. Richteri curas ad librorum manuscriptorum et editionis romanae fidem recognovit et adnotatione critica instruxit Ae. Friedberg, vol. I, D.IV, C.III. 


\subsubsection{Specyfika techniki legislacyjnej}

Do potencjalnych trudności, z jakimi spotykają się przedstawiciele prawa świeckiego w posługiwaniu się aktami normatywnymi kościołów i innych związów wyznaniowych, można zaliczyć sytuacje, w których prawodawcy z tych zrzeszeń nie realizują w pełni zasad techniki legislacyjnej wypracowanych przez naukę prawa, w dużej części zawartych w Rozporządzeniu Prezesa Rady Ministrów z dnia 20 czerwca 2002 r. w sprawie "Zasad techniki prawodawczej" ${ }^{87}$.

Do takich sytuacji należy zaliczyć to, że w przedmiotowych aktach normatywnych nie zawsze podaje się datę dnia ich uchwalenia, natomiast często podaje się datę ich wejścia w życie. Niekiedy stanowi się w nich o „redakcji” aktu normatywnego w sensie jego uchwalenia. Akty normatywne lub ich teksty jednolite czasem są „przyjmowane” lub „zatwierdzane” przez kolegialne organy prawodawcze, co również, jak się wydaje, jest inną formą ich uchwalania.

Kościoły i inne związki wyznaniowe rzadko sporządzają teksty jednolite, a jeżeli już to się dzieje, to niekiedy zamiennie nazywa się taką wersję tekstu „tekstem ujednoliconym”. Bywa także, że wprowadza się zmiany do tekstu pierwotnego, nie informując o tym, przykładowo - w statucie, który ciągle nosi tę samą nazwę i datę pierwotnego uchwalenia, w trakcie nowelizacji zmieniana jest numeracja jednostek redakcyjnych.

W tym wymiarze technicznym także legislacja Kościoła katolickiego ma spore zaległości w stosunku do prawa polskiego.

Oczywiście kościoły i inne związki wyznaniowe nie muszą stosować się do wyżej wymienionego rozporządzenia lub mogą mieć swoje zasady techniki prawodawczej. Jednakże można wysunąć postulat, aby te akty normatywne, które są urzędowo rejestrowane przez organy władzy państwowej, posiadały pewną jakość prawną i charakter znany przedstawicielom doktryny prawa polskiego.

\subsubsection{Język aktów normatywnych}

Kolejny problem związany ze źródłami prawa kościołów i innych związów wyznaniowych to język tych źródeł. Jeśli grupy religijne powstały w Polsce i ich działalność ogranicza się głównie do jej terytorium, to można założyć, że dokumenty te sporządzane są w języku polskim. Źródła prawa mogą być

87 Tekst jedn. Dz.U. z 2016 poz. 283. 
jednak napisane w innym języku. Tak jest przykładowo w przypadku Kościoła katolickiego, dla którego oficjalnym językiem jest łacina. Uważa się bowiem, że jest to jedyny język, który może być „magnifica caelestis doctrinae sanctissimarumque legum veste" ${ }^{88}$. Trzeba jednak zaznaczyć, że Konstytucja apostolska Pastor bonus w art. I6 pozwala, aby, poza łaciną, do Kurii rzymskiej można było się zwracać w językach szerzej obecnie znanych.

Podstawowa ustawa dla Kościoła łacińskiego - kodeks z I983 r. - została opublikowana po łacinie i jak to zaznaczono w normach dotyczących tłumaczeń tego aktu normatywnego na języki narodowe: „Publicam vim et efficacitatem Codicis Iuris Canonicis habet textus unus Latinus" ${ }^{\prime 89}$. Podobnie jest z Kodeksem kanonów Kościotów wschodnich. Jednakże w przypadku aktów normatywnych wydawanych przez organy wewnętrzne tego Kościoła, takie jak Konferencja Episkopatu Polski, biskupi diecezjalni mający swoje diecezje w Polsce, czy też organy prawodawcze instytutów zakonnych, tym językiem będzie język polski.

\subsection{Specyficzny charakter teologiczno-prawny prawa religijnego}

Modelowym dla aktów normatywnych polskiego systemu prawnego jest ich czysto normatywny charakter. Zdarza się, owszem, że w polskich ustawach pojawiają się zdania o charakterze ideologicznym czy programowym, czyli takie, które nie wyrażają norm prawnych. Tak jest zwykle w preambułach do ustaw ${ }^{9 \circ}$. Jednak takie środki nie są często stosowane przez polskiego ustawodawcę. Spotykają się one z mieszanymi opiniami ze strony orzecznictwa i doktryny ${ }^{91}$.

Gdy chodzi o akty normatywne związków wyznaniowych, to może się jednak zdarzyć, że nie będą miały czysto normatywnego charakteru, to znaczy

88 Pius PP. XI, Motu proprio Litterarum latinarum in athenaeo gregoriano constituenda, 20.IO.I924, AAS I6 (I924), s. 4I7 - ,jako wspaniała szata dla niebieskiej doktryny i świętego prawa" (przeł. P. Kroczek).

89 Secretaria Status, Normae de Latino textu Codicis luris Canonici tuendo eodemque alias in linguas convertendo, 28.0I.1983, „Communicationes” I5 (I983), s. 4I „Publiczną moc i skuteczność ma wyłącznie łaciński tekst kodeksu prawa kanonicznego” (przeł. P. Kroczek).

90 Np. Ustawa z dnia 7 września I99i r. o systemie oświaty (tekst jedn. Dz.U. z 2016 r. poz. 1943 z późn. zm.).

9I Zob. M. E. Stefaniuk, Preambuta aktu normatywnego $w$ doktrynie oraz w procesie stanowienia i stosowania polskiego prawa w latach 1989-2007, Lublin 2009. 
takiego, który stwarza dla ich adresatów sytuację right and duty („prawo i obowiązek"). Wówczas to treści czysto normatywne będą występowały w jednym dokumencie z treściami dogmatyczno-moralnymi, duchowymi zachętami ${ }^{22}$. Niekiedy nawet te pozanormatywne treści można określić jako mające charakter informacyjny czy deklaratywny.

Przykładem czysto normatywnej, i to na podstawie prawa pozytywnego, regulacji może być ograniczanie obowiązywania kodeksu z 1983 r. do jednego z Kościołów sui iuris (kan. I KPK ${ }^{93}$ ), czy też przepisy regulujące procedurę wyborczą (np. kan. I77 \$ I KPK), wszystkie terminy zawite, czyli terminy wyznaczone ustawą na wygaśnięcie uprawnień (kan. $1465 \$$ I KPK), czy też sposób liczenia terminów (kan. $203 \$$ I KPK ${ }^{94}$ ).

Treści dogmatyczne zawiera natomiast np. kan. I008 kodeksu z I983 r., który stanowi o tym, że święcenia kapłańskie naznaczają niezatartym charakterem przyjmującego je, czy też kan. 849 w którym stwierdza się, że chrzest uwalnia ludzi od grzechów, odradza ich jako dzieci Boże i przez upodobnienie do Chrystusa niezniszczalnym charakterem włącza ich do Kościoła. Tak samo w art. I $\$ 2$ statutu Kościoła Starokatolickiego Mariawitów znajduje się dogmatyczna deklaracja: „Nadto Kościół uznaje dogmat Niepokalanego Poczęcia Najświętszej Maryi Panny” (por. \2 sKKM).

Natomiast przykładem przepisu zawierającego treści mające charakter informacyjno-dyscyplinarny jest art. I $₫$ I Statutu Kościoła Starokatolickiego Mariawitów - „Nazwa «Mariawita» pochodzi od łacińskich wyrazów Mariae - vita, co oznacza - Życie Maryi; naśladowanie Maryi jest warunkiem pogłębienia życia duchowego w Kościele”. Podobny charakter ma \$ I czy też $\$ 4$ statutu tego Kościoła.

Zachęty natomiast zawiera kan. 280 kodeksu łacińskiego: „Bardzo zaleca się duchownym jakąś formę życia wspólnego, a tam, gdzie ono istnieje, należy je wedle możności zachować"9s. Nie ma w nim wysłowionego nakazu. Wpraw-

92 Por. P. Kroczek, The Art of Legislation..., dz. cyt., s. 209-2I2.

93 Kan. I: „Kanony tego Kodeksu dotyczą jedynie Kościoła łacińskiego” („Canones huius Codicis unam Ecclesiam latinam respiciunt").

94 Kan. $203 \$$ I: „Pierwszego dnia nie wlicza się do terminu, chyba że jego początek zbiega się z początkiem dnia, albo prawo wyraźnie coś innego zastrzega” („Dies a quo non computatur in termino, nisi huius initium coincidat cum initio diei aut aliud expresse in iure caveatur").

95 Can. 280: „Clericis valde commendatur quaedam vitae communis consuetudo; quae quidem, ubi viget, quantum fieri potest, servanda est”. 
dzie prawo zasadniczo jest dane adresatom przez ustawodawcę po to, by go przestrzegać, jednakże niewypełnienie normy z cytowanego kanonu nie może stanowić podstawy do zarzutu.

Niekiedy przepisy mogą być zbitką różnych form. Przykładowo kan. I055 $\$$ I kodeksu ma brzmienie „Małżeńskie przymierze, przez które mężczyzna i kobieta tworzą ze sobą wspólnotę całego życia, skierowaną ze swej natury do dobra małżonków oraz do zrodzenia i wychowania potomstwa, zostało między ochrzczonymi podniesione przez Chrystusa Pana do godności sakramentu"96. Dogmatyczny element to stwierdzenie, że małżeństwo to sakrament (między ochrzczonymi osobami), natomiast prawny element to wyrażenie w postaci normy stanowionej prawa naturalnego - heteroseksualność małżeństwa ${ }^{97}$.

Wspólne występowanie treści o różnym charakterze i odmiennych funkcjach może przybierać dwie formy. Pierwsza z nich to połączenie treści w sposób uporządkowany, na przykład poprzez odpowiednie części dokumentu ${ }^{98}$. Druga możliwa forma to zmieszanie tych treści w sposób nieuporządkowany ${ }^{99}$. Oczywiście ten drugi przypadek stanowi dla interpretatora trudniejsze zadanie. Wymaga ono bowiem oddzielenia zdań kodujących normę prawną od zdań niosących inne treści, po to, aby poddać wykładni wyłącznie zdania zawierające normy prawne.

W tym miejscu trzeba podnieść zagadnienie reguł sensowności czynności konwencjonalnych i norm kompetencyjnych obecnych w prawie związków wyznaniowych. Są one bowiem uwarunkowane teologicznie, czyli zależne od dogmatyczno-moralnego nauczania kościoła lub związku wyznaniowego. Pozytywistyczno-legalistyczna postawa ,interpretatora zewnętrznego” operującego zwykle w prawie polskim musi być skorygowana. Powinien on wziąć pod uwagę osiągnięcia nauk teologicznych i pamiętać, że prawo było stanowione dla wspólnoty religijnej, w klimacie teologicznym i z teologicznych powodów. Wykładający przepisy musi pamiętać, że prawodawca religijny przy, przykładowo,

96 Can. I055 $\$$ I: „Matrimoniale foedus, quo vir et mulier inter se totius vitae consortium constituunt, indole sua naturali ad bonum coniugum atque ad prolis generationem et educationem ordinatum, a Christo Domino ad sacramenti dignitatem inter baptizatos evectum est".

97 Por. L. Örsy, Interpretation: Guiding Principles, [w:] L. Örsy, Theology and Canon Law. New Horizons for Legislation and Interpretation, Collegeville 1992, s. 57.

98 Por. Paulus PP. vi, Constitutio apostolica Indulgentiarum doctrina Sacrarum Indulgentiarum recognitio promulgatur, I.oI.1967, AAs 59 (I967), s. 5-24.

99 Por. Joannes Paulus Pp. II, Adhortatio apostolica Familiaris consortio de Familiae Christianae muneribus in mundo huius temporis, 22.II.I98I, AAS 74 (I982), s. 8I-I9I. 
przyznawaniu kompetencji osobom do czynności konwencjonalnych nie może stosować jedynie prawniczych, choć słusznych reguł, takich jak np. reguła 68 ze zbioru De regulis iuris ${ }^{100}$ głosząca, iż: „Potest quis per alium quod potest facere per se ipsum” ${ }^{\text {Ior. }}$. Musi on liczyć się z teologicznymi uwarunkowaniami swoich prawodawczych decyzji ${ }^{102}$.

$\mathrm{Na}$ tym tle należy podnieść jeszcze jeden problem, którego istnienie powinno być przynajmniej znane „zewnętrznemu interpretatorowi”. Otóż to samo zdanie może mieć charakter normatywny, czyli stwarzać dla adresata sytuację prawa lub obowiązu, a jednocześnie wyrażać określoną treść dogmatyczno-moralną. Przykładowo w sytuacji Kościoła katolickiego każdy nakaz prawny wynikać musi z wiary. Zasadniczo nauczyciel wiary to jednocześnie prawodawca wspólnoty. Tak jest w przypadku biskupów i ciał kolegialnych, do których biskupi należą (zob. np. kan. 330, kan. $333 \$$ I). Podobnie jest na przykład u zielonoświątkowców: „Do właściwości Synodu należy: określanie doktryny kościelnej i zasad wiary oraz stanowienie prawa kościelnego" (art. 7 ust. 2 pkt I PWKZ). Jednakże w tym sformułowaniu chodzi nie tyle o zmianę zasad wiary, ile o zmianę Wyznania wiary Kościoła Zielonoświątkowego w Polsce $(\text { credo })^{\text {103 }}$.

Dla „zewnętrznego interpretatora” problem stanowić mogą odesłania nie do aktów prawnych, lecz dzieł teologicznych. Występują one często w statucie Polskiego Autokefalicznego Kościoła Prawosławnego. Są one jakby podaniem teologicznej podstawy dla normy prawnej i mogą stanowić jej rozwinięcie. Tak jest przykładowo w $\$ 33$ ust. I: „Na czele parafii stoi proboszcz (Ap. I5; VI, 25)”, czy też w $\$ 23$ ust. I: „Biskup Diecezjalny, jako kanoniczny następca Św. Apostołów, jest zwierzchnikiem i reprezentantem swej Diecezji, którą zarządza na podstawie kanonów: Ap.81,83; Ant.9; Kart.6,25; Ap.27; vI,9; Ap.I5,37,55; I,5,I2,I5,I6; VI,34,IO2; VII,4; Ant.I7; Sard.I4; Kart.38,52; Dwukr.9; Bazylego Wielkiego

IOo Bonifatio PP. viII, De regulis iuris, 3.03.I298, [w:] Corpus Iuris Canonici, editio Lipsiensi secunda post Ae. L. Richteri curas ad librorum manuscriptorum et editionis romanae fidem recognovit et adnotatione critica instruxit Ae. Friedberg, vol. 2, Gratz 1959, kol. II22-II24.

IOI "Jeżeli ktoś może zrobić coś przez kogoś innego, to może to zrobić także sam” (przeł. P. Kroczek).

IO2 Por. P. Kroczek, Teologiczne podstawy regut sensu czynności konwencjonalnych i norm kompetencyjnych w prawie kanonicznym i ich konsekwencje dla decyzji prawodawczych, „Annales Canonici” 9 (2013), s. 72.

IO3 Wykładnia przepisów podana ustnie przez biskupa tego Kościoła M. Kamińskiego w rozmowie z autorem 9.IO.20I5 r. (notatka z rozmowy - archiwum prywatne autora, sygn. Kz/I). 
I0,74,88; Teof.Al.4,6” ${ }^{104}$. Takie same odesłania można znaleźć w Pragmatyce Służbowej Kościoła Ewangelicko-Augsburskiego: „O jego [Kościoła] jedności stanowi zgodność w nauce Ewangelii i sprawowaniu Sakramentów (Wyznanie augsburskie art. VII)" (\$56).

Na mieszany teologiczno-prawny charakter endogenicznych aktów normatywnych kościołów i innych związków wyznaniowych wskazują wstępy do nich, przybierające formę deklaracji dogmatyczno-moralno-historycznych.

Bardzo rozbudowany jest Wstęp do Zasadniczego Prawa Kościoła Ewangelicko-Reformowanego w Rzeczypospolitej Polskiej: „Wszechmocny Bóg, Ojciec, Stwórca nieba i ziemi, który panuje nad wszystkim, co istnieje, posłał swego jedynego Syna, Jezusa Chrystusa, jako Zbawcę grzesznego stworzenia. On to mocą Ducha Świętego wybiera i gromadzi spośród całej ludzkości swój Kościół, rządzi nim jako jedyny Pan i jest jego Głową. [...] Wspólnota wierzących, tworząca Kościół Ewangelicko-Reformowany w Polsce [...] Wraz z całym Kościołem Powszechnym przyjmuje apostolskie, nicejsko-konstantynopolitańskie i atanazjańskie wyznanie wiary. Uznaje, że wykład zasad wiary został systematycznie przedstawiony w Katechizmie heidelberskim (1563), Drugiej konfesji helweckiej (1566) i w Konfesji sandomierskiej (1570). Za wzór formy nabożeństwa i innych posług religijnych przyjmuje Agendę gdańską (I637)”. Takie legislacyjne działanie jest przydatne przy prawnym określaniu warunków członkostwa: „Wszyscy, którzy zostali ochrzczeni, uznają sformułowane we Wstępie zasady i w wymaganej formie wyrazili wolę przynależności, tworzą Kościół Ewangelicko-Reformowany w Rzeczypospolitej Polskiej" (art. I PWKE-R). Podobnie zbudowana jest Deklaracja wstępna w Zasadniczym Prawie Kościoła Ewangelicko-Augsburskiego czy Preambuta do Prawa Wewnętrznego Kościoła Ewangelicko-Metodystycznego.

\subsection{Wykładnia prawa związków wyznaniowych}

Następny etap dla organu władzy państwowej mającego za zadanie zastosować przepisy prawa związku wyznaniowego to dokonanie wykładni tekstu tego prawa. Wymaga to odpowiedniego podejścia. Pierwszym krokiem powinno być poznanie zasad wykładni prawa obowiązującego w danym kościele lub

IO4 Użyte skróty są wytłumaczone w A. Znosko, Kanony Kościoła Prawostawnego, Hajnówka 2000, s. 7-8. 
innym związku wyznaniowym. Niezbędne jest także wyjaśnienie normatywnego charakteru tych zasad. Nie ma natomiast, jak się wydaje, konieczności dokładnego poznania, czym dla danego kościoła lub innego związku jest sama wykładnia prawa. Porównanie bowiem prawno-doktrynalnych definicji tej czynności w odniesieniu do prawa polskiego i kanonicznego wykazuje daleko idące podobieństwa ${ }^{\text {105. }}$.

Na początku trzeba sobie uzmysłowić, że interpretacja tekstów religijnych, w tym i prawa religijnego, jest działaniem, które - choć zbliżone pod względem celu i przebiegu do innych form interpretacji (prawniczej, literackiej) - może jednak różnić się od nich metodami i zakresem ${ }^{\mathrm{rob}}$. Wiąże się to $\mathrm{z}$ tradycją interpretacji, jej zakresem i celami, które stawiano w obrębie środowiska stworzonego przez daną religię. W trzech wielkich tradycjach religijnych: judaizmie, chrześcijaństwie i islamie interpretacja świętych tekstów odgrywała wielką rolę. $\mathrm{W}$ innych tradycjach była mniej istotna ${ }^{\mathrm{I07}}$. Dla tych trzech religii podstawą wiary i jej praktykowania - co oczywiście wiąże się z regułami życia podanymi wiernym w formie nakazów i zakazów - są święte księgi. Księgi te, jako natchnione lub objawione, mają wieczną wartość dla danej religii. Już samo to wymusza ich interpretację w zależności od warunków życia wiernych. Ta tradycja interpretacji testów religijnych (religijno-prawnych) rzutuje na wykładnię tekstów prawnych.

Przechodząc od ogólnego do szczegółowego ujęcia wykładni, trzeba podać przykłady zasad wykładni.

W judaizmie funkcję interpretatorów świętych ksiagg, pełnili zawsze rabini - oni dokonywali wykładni prawa żydowskiego. Jednocześnie byli i są przywódcami religijnymi i kapłanami wspólnoty żydowskiej. To powoduje, że nie można w prosty sposób przenosić metod postępowania wykładni znanych z prawodawstwa państwowego do prawa żydowskiego. Podstawowe reguły interpretacji tekstów świętych i zarazem wykładni prawa są takie, że prawo będące pochodzenia boskiego - musi być traktowane z wielkim szacunkiem. Racjonalność i ortodoksja prawodawcy są więc poza wszelką dyskusją. Prawnicza tradycja żydowska nie wypracowała naczelnego organu, którego zadaniem byłaby powszechnie obowiązująca wykładnia prawa. Jednakże pewne

IO5 Por. P. Kroczek, Zasada „clara non sunt interpretanda” $w$ prawie kanonicznym, wyd. 2 poprawione, Kraków 2005, s. 6-9.

Io6 Por. K. Greenawalt, Legal Interpretation..., dz. cyt., s. I07.

I07 Por. K. Greenawalt, Legal Interpretation..., dz. cyt., s. Io9. 
zasady dotyczące hierarchii wykładni obowiązują - pierwszeństwo przyznaje się przeważnie wykładni dokonanej przez przodków oraz uznane powszechnie autorytety w danej dziedzinie; walor prawidłowego postępowania przyznaje się również temu, co do czego zadecydowała większośćc ${ }^{108}$.

Gdy chodzi o chrześcijaństwo, to najbardziej rozwiniętą doktrynę prawniczą, w tym dotyczącą wykładni prawa, ma Kościół katolicki. W jego prawie istnieje ścisła relacja pomiędzy tworzeniem przepisów a ich interpretacją. „W systemie prawnym Kościoła prawodawca i interpretator nie tylko pracują wspólnie [...], ale co więcej, sam prawodawca jest pierwszym interpretatorem prawa" ${ }^{\circ 09}$. Taki metodologiczno-praktyczny postulat jest także obecny w polskiej teorii prawodawstwa. Przyjęła się zasada mówiąca, że reguły redagowania tekstu mają wzorować się na regułach jego interpretowania ${ }^{110}$. Stąd też postulat, aby prawodawca nie formułował tekstów prawnych wbrew przyjętym regułom ich odczytywania ${ }^{11}$.

Jednakże w przeciwieństwie do prawa polskiego prawo kanoniczne zawiera regulacje dotyczące zasad wykładni prawa. Dyrektywy interpretacyjne zawarte są w kanonach od I6 do 19 oraz 27 kodeksu lacińskiego. Mają one odpowiedniki w postaci kanonów od I498 do I5OI oraz kan. I508 kodeksu wschodniego. Ich brzmienie w tym drugim źródle jest niemal identyczne jak w źródle pierwszym.

Szczególne znaczenie ma kan. I7 KPK (kan. I499 KKKw). Jest on fundamentalny dla poprawnego rozumienia kościelnych tekstów prawniczych. Ma on następujące brzmienie: „Ustawy kościelne należy rozumieć według własnego znaczenia słów, rozważanego w tekście i kontekście. Jeśli pozostaje ono wątpliwe i niejasne, należy uwzględnić miejsca paralelne, gdy takie są, cel i okoliczności ustawy oraz myśl prawodawcy" ${ }^{\text {II }}$. Z punktu widzenia analizowanego tematu istotne jest, że należy „uwzględnić miejsca paralelne”. Chodzi o miejsca para-

Io8 Por. S. L. Stone, In Pursuit of the Counter-Text: the Turn to the Jewish Legal Model in Contemporaty Americal Legal Thought, „Harwdard Law Rview” 106 (I993) No. 4 , s. $836-837$.

I09 L. Gerosa, Interpretacja prawa w Kościele. Zasady, wzorce, perspektywy, przeł. K. Kubiś, A. Porębski, Kraków 2003, s. I5I.

IIo Por. S. Wronkowska, Z. Ziembiński, Zarys teorii prawa, dz. cyt., s. I34.

III Por. M. Zieliński, Wyktadnia prawa. Zasady. Reguty. Wskazówki, Warszawa 2002, s. 59.

II2 Can. I7: „Leges ecclesiasticae intellegendae sunt secundum propriam verborum significationem in textu et contextu consideratam; quae si dubia et obscura manserit, ad locos parallelos, si qui sint, ad legis finem ac circumstantias et ad mentem legislatoris est recurrendum". 
lelne w tekstach prawnych traktujących o tych samych lub podobnych zagadnieniach, zawierające taką samą regulację różnych spraw, wyrażające tę samą zasadę prawną, albo też gdy występują w nich takie same lub podobne słowa. W literaturze przedmiotu ${ }^{\mathrm{II} 3}$ dominuje przekonanie, że miejsc paralelnych należy szukać nie tylko w samym kodeksie łacińskim ${ }^{\mathrm{II}}$, lecz także w kodeksie dla katolickich Kościołów wschodnich. Wskazuje się przykładowe miejsca. Jest to np. kan. I88 w KPK, który brzmi: „Mocą samego prawa nieważna jest rezygnacja pod wpływem ciężkiej i niesprawiedliwej bojaźni, podstępu, błędu istotnego lub symonii”. W wersji łacińskiej, co ma znaczenie dla tego rozważania, ma on brzmienie: „Renuntiatio ex metu gravi, iniuste incusso, dolo vel errore substantiali aut simoniace facta, ipso iure irrita est”. Z powodu tego, że dolo i errore są połączone spójnikiem vel, nie jest pewne, czy termin substantiali odnosi się tylko do errore czy również do dolo. Z pomocą przychodzi kan. 968 kodeksu katolickich Kościołów wschodnich, który zawiera paralelne miejsce wobec cytowanego wyżej kan. I88 kodeksu łacińskiego. Kanon 968 kodeksu wschodniego brzmi tak: „Z mocy samego prawa nieważna jest rezygnacja dokonana pod wpływem ciężkiej i niesprawiedliwej bojaźni, podstępu, istotnego błędu lub symonii” "Is , czyli w wersji oryginalnej (także łacińskiej): „Renuntiatio facta ex metu gravi et iniuste incusso, dolo, errore substantiali aut simoniace ipso iure nulla est”. Po wyrazie dolo wstawiono przecinek, tak więc jest jasne, że substantiali odnosi się tylko do errore. Inne przykłady interpretacji poprzez odwołanie się do miejsc paralelnych to np. kan. I42 $\$ 2 \mathrm{KPK}$, który staje się jaśniejszy po odniesieniu się do kan. $992 \$ 2$ z KKKW; kan. I32 $\$ 2$ z KPK może być wyjaśniony poprzez kan. $982 \$ 2 \mathrm{z}$ KKKw. Takie pary tworzą też kan. 39 z KPK i kan. I5I6 z KKKW, kan. I89 $\$ 3$ i kan. $970 \$$ I z KKKW ${ }^{116}$.

II3 Zob. P. Kroczek, O pożytkach ze znajomości prawa Kościotów wschodnich dla prawodawcy tacińskiego, [w:] Semper fidelis, Vedecká konferencia s medzinárodnou účastou II. marec 20I0, red. F. Čitbaj, Prešov 20II, s. 36-42.

II4 Poprzednikiem kan. I7 był w CIC can. I8. Przy redakcji KPK ze starej wersji usunięto słowo Codicis. Dzięki temu w poszukiwaniu miejsc równoległych w prawie można brać pod uwagę nie tylko sam kodeks, ale wszystkie ustawy kościelne. Przykładowo, gdy chodzi o kanony z Księgi IV KPK miejsc paralelnych należy szukać w Konstytucji o liturgii świętej Sacrosanctum concilium, w księgach liturgicznych i innych dokumentach.

II5 Can. I88: „Renuntiatio facta ex metu gravi et iniuste incusso, dolo, errore substantiali aut simoniace ipso iure nulla est".

II6 Zob. rozdział Canonical Interpretation by Recourse to „Parallel Passages”, [w:] J. Abbass, Two Codes in Comparison, dz. cyt., s. I33-I49. 
Jak widać na powyższych przykładach, prawodawca kościoła łacińskiego przy stanowieniu nowego prawa, poprawianiu go, a szczególnie przy dokonywaniu korekty jego zapisu czy rozumienia poprzez autentyczną interpretację, może i powinien odwoływać się do prawa wschodniego. Regulując określoną materię w kręgu swojej prawodawczej kompetencji, prawodawca ma możliwość zwrócenia się szczególnie do Kodeksu kanonów Kościotów wschodnich jako do pomocnego wzoru, którego zapisy mogą ułatwić interpretację, a jej wyniki uczynić pewniejszymi.

Jeżeli chodzi o islam, to można dodać, że o ile w Koranie jest zaledwie kilka miejsc, które można nazwać elementami doktryny prawnej, o tyle jest ona mocno rozwinięta właśnie w literaturze hadithu, a także w innych późniejszych prawniczych tekstach, które zostały napisane w celu kodyfikacji i określenia różnych wersji prawa islamskiego ${ }^{117}$. Prawnicy islamscy zawsze odróżniali jurysprudencję ( $f k h)$ od prawa Bożego. To prawo bowiem jest doskonałe, zaś jego ludzkie rozumienie już nie. Te konkurujące ze sobą wykładnie prawa nieraz różnią się znacząco od siebie i są sposobem na dopasowanie życia wiernego do różnych warunków i okoliczności życiowych ${ }^{118}$. Przyjmuje się jednak, że powszechna zgoda biegłych w prawie islamskim na temat znaczenia Koranu czy Sunny świadczyła o pewności wykładni ${ }^{119}$.

Jeżeli w przypadku jakiegoś kościoła lub innego związku wyznaniowego takich zasad wykładni nie ma, to należy odwołać się po części do tradycji religijnej interpretacji oraz, jak się wydaje, skorzystać z koncepcji wykładni prawa, zasad i metod wykładni wypracowanych przez naukę prawa. Trzeba jednak uwzględnić specyfikę podejścia do własnego prawa i to, że prawo stanowione było dla wspólnoty religijnej i dla niej ma być interpretowane.

Zawsze należy skonfrontować wynik wykładni prawa z podstawowymi zasadami dogmatycznymi i moralnymi danego kościoła lub innego związku wyznaniowego. Trudno bowiem przyjąć, że normy prawne mogą być sprzeczne z dogmatyczno-moralnym nauczaniem kościoła lub związku wyznaniowego. Niemniej jednak na pytanie, czy dokonujący wykładni prawa związku wyznaniowego musi znać w pełni nauczanie danego religijnego zrzeszenia,

II7 Por. Law, [w:] P. S. Groff, O. Leaman, Islamic Philosophy A-Z, Edinburgh 2007, s. I27. Szeroko o tym zob. J. Schacht, An Introduction to Islamic Law, Oxford 1983.

II8 Por. Shari'ah, [w:] O. Leaman, L. Ali, Islam. The Key Concepts, dz. cyt., s. I23.

II9 Por. W. B. Hallaq, A History of Islamic Legal Theories, Cambridge I997, s. 75-77. 
aby skutecznie podołać swojemu zadaniu, można dać odpowiedź przeczącą. Wprawdzie interpretacja prawa własnego związku wyznaniowego powinna być dokonywana z doktrynalnej perspektywy, jednakże nie jest wymagana pełna znajomość zasad doktrynalno-moralnych głoszonych przez kościół lub inny związek wyznaniowy, lecz jedynie ich zasadniczej części, i to tej, która odnosi się bezpośrednio do uzyskanej normy prawnej ${ }^{\text {120 }}$.

Zwykle podstawowe prawo wewnętrzne kościołów i innych związków wyznaniowych nie daje się sprowadzić do czysto jurydycznego elementu, lecz zawiera odwołanie do fundamentalnych dokumentów natury dogmatyczno-moralnej ${ }^{121}$. Przykładowo Zasadnicze Prawo Wewnętrzne Kościoła Ewangelicko-Augsburskiego w Deklaracji wstępnej stanowi, że Kościół ten buduje swoją wiarę wyłącznie na pismach Starego i Nowego Testamentu, a za ich obowiązujący wykład uznaje trzy starochrześcijańskie wyznania wiary (apostolskie, nicejsko-konstantynopolitańskie, atanazjańskie) oraz księgi wyznaniowe zawarte w Księdze zgody z I580 r. (Maty katechizm, Duży katechizm, Wyznanie augsburskie, Obrona Wyznania augsburskiego, Artykuty szmalkaldzkie, Formuta zgody).

Co istotne, kodeks prawa kanonicznego z 1983 r. nie przywołuje wprost podstaw wiary katolickiej. Aby więc odwołać się do fundamentalnych dokumentów tego Kościoła, trzeba szerszej religijnej wiedzy. Podstawowe źródła wiary to oczywiście: Pismo Święte, Tradycja, dokumenty Magisterium ${ }^{122}$. Dla celów praktycznych, jak się wydaje, wystarczy odwołać się do Katechizmu Kościota Katolickiego z 1992 r., który jest „compendium totius doctrinae catholicae, tam de fide quam de moribus" ${ }^{123}$.

Podsumowując ten punkt, należy powiedzieć, że z wyjątkiem Kościoła katolickiego, można mówić o pewnej uniwersalizacji zasad wykładni związków

I2O Por. P. Kroczek, Zasada „clara non sunt interpretanda”..., dz. cyt., s. IIO-III.

I2I Por. M. Plisiecki, Osoba prawna w prawie wewnętrznym kościotów..., dz. cyt., s. 34 .

I22 Zob. Joannes Paulus Pp. II, Allocutio Ho desiderato a Summo Pontifice in aula supra porticum Vaticanae basilicae habita, ad novum Codicem Iuris Canonici, paucis ante diebus promulgatum, publice exhibendum, 3.02.1983, AAS 75 (1983), pars I, s. 455-463, szczególnie s. 463.

I23 Joannes Paulus pp. II, Constitutio apostolica Fidei depositum qua Catholicae Ecclesiae catechismus post Concilium Oecumenicum Vaticanum II instauratus publici iuris fit, II.IO.1992, AAS 86 (I994), s. II4: „kompendium całej katolickiej doktryny zarówno wiary, jak i obyczajów” (przeł. P. Kroczek). 
wyznaniowych $^{124}$. Ponieważ nie wypracowały one szczegółowych zasad interpretacji własnych tekstów prawnych, można stosować zasady podane przez polską doktryną prawniczą, uwzględniając specyfikę podstaw doktrynalno-moralnych prawa przy ocenie wyników wykładni.

\subsection{Prawo związków wyznaniowych - prawdziwe prawo}

W podsumowaniu rozważań tego rozdziału można powiedzieć, że prawo endogeniczne kościołów i innych związków wyznaniowych to prawdziwe prawo, a nie prawo jedynie przez analogię do prawa państwowego ${ }^{125}$. Spełnia ono bowiem wymagania, które stawia prawdziwemu prawu prawoznawstwo (principles of legality) ${ }^{126}$. Prawo to powinno być: I) generalne, 2) promulgowane, 3) prospektywne, 4) jasne, 5) logiczne, 6) możliwe do wypełniania, 7) cechujące się stałością ${ }^{127}$.

Kryterium uznania za prawdziwe prawo nie powinno być spełnienie znanych z nauki prawa wyżej wymienionych postulatów, lecz to, że jest ono postrzegane przez członków religijnej wspólnoty jako wyznacznik prawidłowego w obrębie kościoła lub związku wyznaniowego postępowania. Misja danego religijnego zrzeszenia wyznacza treść i kształt prawa ${ }^{\mathrm{I28}}$.

Można dodać, że Kościół katolicki uznaje za prawdziwe prawo, czyli obowiązującą wewnętrznie regulację, te akty kościołów lub innych związków wyznaniowych, które one same ustanowity dla siebie. Co więcej, nakazuje ich stosowanie. Dotyczy to przede wszystkim sędziów kościelnych, którzy muszą

I24 Zob. M. Safjan, Uniwersalizacja wyktadni prawa, [w:] W poszukiwaniu dobra wspólnego. Księga jubileuszowa Profesora Macieja Zielińskiego, red. A. Choduń, S. Czepita, Szczecin 20IO, s. 27I-298.

I25 Zob. w kontekście prawa kanonicznego: L. Örsy, Corecco's Theology of Canon Law: A Critical Appraisal, „The Jurist” 53 (1993), s. I94; T. Pawluk, Prawo kanoniczne wedtug Kodeksu Jana Pawta II, t. I: Zagadnienia wstępne i normy ogólne, Olsztyn 1985, s. 28; R. Sobański, Nauki podstawowe prawa kanonicznego, t. I: Teoria prawa kanonicznego, Warszawa 200I, s. I2-16.

I26 O wymaganiach stawianych prawu zob. np.: L. Fuller, The Morality of Law, New Haven 1967, s. 39; J. Raz, The Authority of Law. Essays on Law and Morality, Oxford I979, s. 216-2I7.

I27 Zob. P. Kroczek, The Art of Legislation..., dz. cyt., s. 38.

I28 Por. R. Sobański, Prawo kanoniczne a krajowy porzadek prawny, dz. cyt., s. I4. 
wypowiedzieć się na temat nieważności małżeństwa ochrzczonych akatolików, posługując się prawem egzogenicznym wobec ich własnego prawa kanonicznego (art. $4 \$ \mathrm{I} \mathrm{I}^{\circ}$ i $2^{\circ}$, art. $2 \$ 2 \mathrm{I}^{\circ}$ i $2^{\circ}$ instrukcji Dignitas connubii ${ }^{\mathrm{I} 29}$ ).

\subsection{Relacja prawa kościołów lub innych związków wyznaniowych do prawa polskiego}

\subsubsection{Uwagi terminologiczne}

Dla jasności terminologicznej trzeba powiedzieć, że poprzez „prawo (wewnętrzne) związków wyznaniowych” lub „prawo własne” należy rozumieć prawo, zazwyczaj pochodzenia endogenicznego (stanowione lub zwyczajowe), obowiązujące członków społeczności religijnych głównie w stosunkach wewnętrznych $^{130}$. Nie ma przy tym znaczenia treść tych regulacji. Mogą one dotyczyć zachowań związanych bezpośrednio z realizacją wiary lub czysto technicznych spraw dotyczących organizacji i funkcjonowania tych wspólnot.

Jak zauważono we wstępie książki, użycie terminu „prawo religijne” na określenie prawa własnego związków wyznaniowych jest uzasadnione tym, że prawo i doktryna tych związków są ze sobą powiązane. To powiązanie istnieje nie tylko w tym sensie, że doktrynalno-moralne zasady są podstawą rozwiązań prawnych $^{131}$, ale także $\mathrm{w}$ tym sensie, że to prawo ma strzec tożsamości (również doktrynalnej) związku wyznaniowego ${ }^{\mathrm{I} 32}$.

Z kolei termin „prawo kanoniczne” (ius canonicum) zwykle jest odnoszony do prawa Kościoła katolickiego (we wszystkich jego obrządkach) ${ }^{133}$. Jednostką redakcyjną kodeksów tego Kościoła jest kanon (canon). Jednakże termin „prawo kanoniczne" występuje również w ustawie indywidualnej Wschodniego Kościoła

I29 Pontificium Consilium de Legum Textibus, Istruzione Dignitas connubii sulle norme da osservarsi nei tribunali ecclesiastici nelle cause matrimoniali, 25.0I.2005, Città del Vaticano 2005; polskie tłumaczenie w: Komentarz do Instrukcji procesowej „Dignitas connubii”, red. T. Rozkrut, Sandomierz 2007.

I30 Zob. M. Plisiecki, Prawo wewnętrzne związków wyznaniowych, [w:] Leksykon prawa wyznaniowego. Ioo podstawowych pojęć, dz. cyt., s. 33I-336.

I3I Zob. na ten temat: P. Kroczek, Teologiczne podstawy regut sensu czynności konwencjonalnych..., dz. cyt., s. 55-73.

I32 Por. R. Sobański, Kościót-prawo-zbawienie, dz. cyt., s. 24I.

I33 Jak zanzaczono we Wstępie, w tym właśnie znaczeniu termin ten jest stosowany w niniejszej książce. 
Staroobrzędowego, nie posiadającego hierarchji duchownej (art. 7 u.s.p.w.k.s.). Jeżeli „prawo kanoniczne” rozumiane zostanie jako „prawo kanonów”, to ten termin może być użyty w kontekście prawa Kościoła polskokatolickiego (jednostki redakcyjne statutu to także kanony) oraz Kościoła prawosławnego - nie tylko tego działającego w Polsce. Prawo tego Kościoła to prawo zebrane w kanonach, czyli zbiorach reguł postępowania. Nie ma podstaw natomiast, aby prawo innych Kościołów chrześcijańskich nazywać prawem kanonicznym ${ }^{134}$. Trzeba jednak zaznaczyć, że Kościół Starokatolicki Mariawitów nazywa swoje prawo „prawem kanonicznym” (art. II $\$$ I i art. XIV $\$ 2$ SKSM).

Termin „prawo statutowe” lub „prawo własne statutowe” w kontekście kościołów i innych związków wyznaniowych powinno być odnoszone jedynie do tych religijnych zrzeszeń, które mają ,statut” jako podstawę swojej działalności.

Widać pewną zależność nazw głównych ustaw kościołów i innych związków wyznaniowych od liczby obowiązujących w nich aktów normatywnych - jeśli tego typu aktów jest więcej, to ustawa główna przyjmuje raczej nazwę „prawo (wewnętrzne)”. Można dodać, że Kościół Starokatolicki Mariawitów wkrótce zmieni nazwę swojej wewnętrznej ustawy ze „statut” na „prawo wewnętrzne”. Z pewnością nie można prawa Kościoła katolickiego nazywać statutowym. Jest to bowiem prawo własne, niezależne, tworzące kościelny system prawny ${ }^{135}$.

Wyrażenie „prawo kościelne” może być odnoszone do wszystkich regulacji związków wyznaniowych o nazwie „kościół”, choć oczywiście najczęściej bywa kojarzone z prawem Kościoła katolickiego.

Natomiast, jak powszechnie wiadomo, zwrot „prawo wyznaniowe” to regulacje wydane lub uznane przez państwo, dotyczące najszerzej pojmowanej sfery religijnej życia człowieka, a więc wynikające z wolności sumienia i wyznania ${ }^{136}$.

\subsubsection{Teorie relacji}

Literatura przedmiotu dostarcza wyjaśnień na temat stosunku prawa świeckiego do regulacji religijnych przedstawiając teoretyczne modele ich relacji. Można

I34 Inaczej A. Tunia, Recepcja prawa wewnętrznego..., dz. cyt., s. 39.

I35 Por. W. Uruszczak, Recepcja prawa kanonicznego w obowiązującym prawie polskim, dz. cyt., s. 9.

I36 Por. M. Pietrzak, Prawo wyznaniowe, [w:] Leksykon prawa wyznaniowego. Ioo podstawowych pojecć, dz. cyt., s. 336-338. 
ograniczyć się do wymienienia kilku teoriii ${ }^{137}$. Są one pochodną szerszego problemu stosunku państwa do kościołów lub innych związków wyznaniowych ${ }^{138}$.

Przytoczenie modeli stosunku prawa państwowego do prawa związków wyznaniowych, w przeciwieństwie do modeli relacji państwa do religijnych zrzeszeń, jest celowe. Żaden bowiem z tych pierwszych modeli nie obowiązuje absolutnie i może być ad casum, choć w pewnych granicach, przyjęty do stosowania przez organ władzy publicznej. Natomiast model relacji państwa do kościołów lub innych związków wyznaniowych jest nakazany w prawie i nie może być uznaniowo zmieniany przez stosujących prawo.

\subsubsection{Teoria pozaprawnej natury prawa związków wyznaniowych}

Teoria pozaprawnej natury prawa wewnętrznego związków wyznaniowych utrzymuje, że prawo jako źródło powszechnie obwiązujących norm może pochodzić jedynie od organów państwa. Regulacje stanowione wewnątrz związków religijnych apriorycznie nie są prawem w sensie ścisłym, lecz posiadają pozaprawną naturę, co oznacza, że mają charakter norm moralnych lub dyscyplinarnych.

W warunkach polskich trudno powoływać się na tę teorię. Prawo wyznań religijnych, nawet jeżeli nie wypełnia standardów prawa polskiego dotyczących jakości prawnej, wciąż jest prawem, to znaczy zawiera normy, które obowiązują wiernych należących do religijnych zrzeszeń. Nie zawiera ono wyłącznie doktrynalno-moralnych zaleceń czy wskazówek. Jest to prawdziwe prawo, ma bowiem normatywny charakter, nie jest tylko w formie analogiczne do prawa państwowego.

\subsubsection{Teoria natury statutowej prawa związków wyznaniowych}

Teoria natury statutowej norm prawa wewnętrznego związków wyznaniowych powstała w systemach mocno rozdzielających państwo od tych zrzeszeń - w sytuacji, gdy państwo odmawiało osobowości publicznoprawnej tym związkom,

I37 Por. H. Misztal, Polskie prawo wyznaniowe, t. I, dz. cyt., s. 34-36; A. Mezglewski, H. Misztal, P. Stanisz, Prawo wyznaniowe, dz. cyt., s. 5-6, W. Uruszczak, Recepcja prawa kanonicznego w obowiązujacym prawie polskim, dz. cyt., s. 5-6.

I38 Por. M. Pietrzak, Prawo wewnętrzne (kanoniczne) Kościotów i związków wyznaniowych w polskim systemie prawnym, [w:] Prawo panstwowe a prawo wewnętrzne związków wyznaniowych..., dz. cyt., s. I37. 
uważając je za organizacje lub zrzeszenia czysto prywatne, wówczas ich prawo endogeniczne automatycznie stawało się prawem statutowym. Prawo to więc mogło obowiązywać tylko w stosunkach wewnętrznych danego związku wyznaniowego. Państwo, zgodnie z ogólnymi regułami, pozwala na zachowanie mocy prawnej tego prawa wewnętrznego, o ile to prawo nie jest sprzeczne z prawem państwowym.

Ta teoria jest w kontekście polskim trudna do utrzymania. Kościoły i inne związki wyznaniowe (te posiadające osobowość prawna) funkcjonują w porządku prawnym państwa jako autonomiczne i samoistne podmioty, zarówno w obrębie prawa prywatnego, jak i publicznego. Ich endogeniczne prawo nie jest zatem prawem statutowym, lecz ich prawem własnym, jako suwerennych wspólnot. Organy władzy państwowej nie mają kompetencji do podejmowania regulacji w tym zakresie ${ }^{139}$.

Kościoły i inne związki wyznaniowe sąświadome swojej pozycji prawnej, czemu dają wyraz w statutach. Zarówno ustanawianie prawa wewnętrznego, jak i jego zmiana lub zwolnienie od przestrzegania niektórych jego przepisów leży w kompetencji wyłącznie władz kościelnych (zob. $\$ 44$ ust. 2 SWPAKP, kan. 85 KPK).

Oczywiście, niektóre kościoły czy związki wyznaniowe mogą zrezygnować z tej części swej autonomii i pozwolić, przykładowo, na zatwierdzanie własnych ustaw lub ich nowelizacji przez organy władzy państwowej lub dokonywać tych zmian w swoim prawie w porozumieniu z władzami państwowymi (zob. art. I4 $\$$ I SKSM, $\$ 43$ SKKM).

\subsubsection{Teoria pełnej skuteczności prawnej prawa związków wyznaniowych}

Teoria skuteczności prawnej prawa wewnętrznego głosi, że prawo związków wyznaniowych obowiązuje powszechnie w danym państwie lub że jest to nawet prawo ponadpaństwowe. Oczywiście możliwe są także pewne wyłączenia spod reżimu tego prawa.

Podstawą tej teorii było założenie, że na danym obszarze dominuje jedna religia, która mając charakter uniwersalny, stwarza - niezależnie nawet od podziałów państwowych - jedno societas, przykładowo: societas

I39 Por. W. Uruszczak, Recepcja prawa kanonicznego w obowiazującym prawie polskim, dz. cyt., s. II. 
christiana $^{\mathrm{I} 40}$. Prawo wewnętrzne kościoła lub innego związku wyznaniowego traktowane było jako część prawa państwowego.

Aktualnie ten model, poza państwami wyznaniowymi, nie jest możliwy do zastosowania. Proces laicyzacji prawa, widoczny wyraźnie w prawie małżeńskim czy karnym, doprowadził do sytuacji, w której obowiązywanie prawa związku wyznaniowego na równi z prawem stanowionym przez państwo, a nawet ponad nim, jest ze względów aksjologicznych niemożliwe. Obecnie systemy prawne, choć oczywiście związane z moralnością poprzez określone regulacje i relacje funkcjonalne ${ }^{\mathrm{I} 4 \mathrm{I}}$, jawią się jako wyodrębnione i autonomiczne wobec religii i wypływających $\mathrm{z}$ ich doktryn norm życia społeczeństw ${ }^{\mathrm{T} 42}$.

Dodatkowo należy zauważyć, że ius commune stanowiło powszechną podstawę prawa materialnego i proceduralnego, choć zasadniczo tylko w świecie

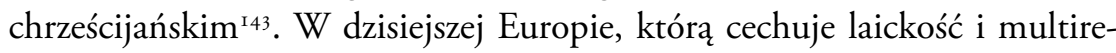
ligijność, model prawa ius commune oparty na chrześcijaństwie jest raczej niemożliwy do przyjęcia ${ }^{\mathrm{I} 44}$.

\subsubsection{Teoria ograniczonej skuteczności prawnej \\ prawa związków wyznaniowych}

Teoria ograniczonej skuteczności prawnej prawa związków wyznaniowych ma szerokie zastosowanie w rzeczywistości prawnej w Polsce. Przyjmuje się powszechnie orzecznictwo Sądu Najwyższego w tym przedmiocie ${ }^{145}$.

I40 Tego terminu nie można mylić z civitas christiana, które oznacza państwo chrześcijańskie.

I4I Na przykład w polskim prawie karnym art. I48 $\$$ I odpowiada zasadniczo normatywnie v Przykazaniu Bożemu. Także określenia wartościujące, np. „szczególne okrucieństwo" z art. I48 \$2 pkt I, art. I97 \$4, art. $207 \$ 2$, art. $247 \$ 2$ Ustawy z dnia 6 czerwca 1997 r. Kodeks karny (tekst jedn. Dz.U. z 2016 r. poz. II37 z późn. zm.) należy interpretować w odniesieniu do moralności. Zob. na ten temat np. L. Morawski, Wstęp do prawoznawstwa, Toruń 2009, s. 39-47.

I42 Por. R. Sobański, Prawo jako wartość, „Prawo Kanoniczne” 42 (I999) nr 3-4, S. II.

I43 Por. J. A. Brundage, Medieval Canon Law, London-New York 1995, s. 58.

I44 Por. P. Kroczek, Czy system prawa kanonicznego może być wzorcem dla systemu prawnego federacji państw?, „Prawo Kanoniczne” 59 (2016) nr 2, s. 73-87.

I45 Orzeczenie Sądu Najwyższego - Izba Cywilna z dnia I2 marca 1997 r., II CKN 24/97, Legalis nr 6336r; Orzeczenie Sądu Najwyższego - Izba Cywilna z dnia 27 lipca 2000 r., IV CKN 88/o0, Legalis nr 548I5; Orzeczenie Sądu Najwyższego - Izba Cywilna z dnia 24 marca 2004 r., IV CK 108/03, Legalis nr 67840; Orzeczenie Sądu 
Generalnie można powiedzieć, że ta teoria opowiada się za skutecznością norm prawa religijnych zrzeszeń na forum prawa polskiego, lecz jedynie w takim zakresie, w jakim jest to uzależnione od uznania przez państwo. Przepisy prawa związków wyznaniowych nie mieszczą się bowiem w katalogu powszechnie obowiązującego prawa w Rzeczypospolitej Polskiej (zob. art. 87 Konstytucji RP) ${ }^{\mathrm{I} 46}$. Takie stanowisko wynika także z art. 25 ust. 3 Konstytucji RP, według którego stosunki między państwem a kościołami i innymi związkami wyznaniowymi są kształtowane na zasadach poszanowania ich autonomii oraz wzajemnej niezależności każdego w swoim zakresie. W praktyce chodzi o taki zakres, jaki jest niezbędny dla funkcjonowania podmiotów istniejących w dwóch porządkach prawnych.

W ramach tej teorii można zauważyć rozbieżności w ocenie skutków, które może wywoływać naruszenie norm endogenicznych kościołów lub innych związków wyznaniowych. Działanie sprzeczne z prawem związków wyznaniowych może prowadzić do nieważności czynności prawnej ${ }^{\mathrm{I}}{ }^{47}$, lecz nie musi. O tym, czy i ewentualnie w jakim zakresie nieważność kanoniczna lub jej przyczyny mogą wpływać na cywilnoprawną skuteczność czynności prawnej, przesądza ostatecznie prawo państwowe. Nie ma bowiem w prawie polskim ogólnej podstawy prawnej, na podstawie której można by przyjąć, że cywilnoprawna skuteczność czynności prawnych dokonywanych przez kościelne osoby prawne zależy od ich skuteczności na forum prawa religijnego $^{148}$.

Omawiana teoria nie rozstrzyga do końca podstaw prawnych skuteczności prawa związków wyznaniowych w krajowym porządku prawnym. Jednakże

Najwyższego - Izba Cywilna z dnia 2 lutego 2005 r., IV CK 480/04, Legalis nr 87008; Orzeczenie Sądu Najwyższego - Izba Cywilna z 17 lutego 2005 r., IV CK 582/04, Legalis nr 89892; Uchwała Sądu Najwyższego - Izba Cywilna z dnia I9 grudnia 2008r., III CZP I22/o8, Legalis nr II2754.

I46 Por. Wyrok Naczelnego Sądu Administracyjnego z dnia 8 stycznia 2008 r., II GSK 286/o7, Legalis nr 96023 z tezą: „Kodeks Prawa Kanonicznego jest autonomicznym prawodawstwem Kościoła rzymskokatolickiego. Oznacza to, że akt ten nie mieści się w katalogu powszechnie obowiązującego prawa w Rzeczypospolitej Polskiej”.

I47 Por. Orzeczenie Sądu Najwyższego - Izba Cywilna z dnia 27 lipca 2000 r., IV CKN 88/oo, Legalis nr 548I5; Orzeczenie Sądu Najwyższego - Izba Cywilna z dnia 24 marca 2004 r., IV CK IO8/03, Legalis nr 67840.

I48 Por. Uchwała Sądu Najwyższego - Izba Cywilna z dnia I9 grudnia 2008 r., III CZP I22/08, Legalis nr II2754. 
pozwala na stwierdzenie, że porządki prawne - państwowy i religijne - wzajemnie się uzupełniają ${ }^{\mathrm{I}}{ }^{49}$.

\subsubsection{Teoria recepcji prawa związków wyznaniowych}

W teorii recepcji prawa wewnętrznego związków wyznaniowych przez prawo świeckie kluczowym terminem jest „recepcja prawa”. Ten termin może być rozumiany na wiele sposobów ${ }^{150}$.

Zasadniczo recepcja prawa oznacza, po pierwsze, proces polegający na przyjęciu regulacji (terminologii prawnej, instytucji prawnych, zasad prawnych, norm prawnych) egzogenicznych (stanowionych lub zwyczajowych) powstałych w jednej wspólnocie przez drugą wspólnotę (państwo, naród, czy inną społeczność). Jest to więc transfer prawa. Może on być zamierzony, a nawet sterowany przez władzę danej wspólnoty, lub też oddolny i nieintencjonalny. Po drugie, wyrażenie „recepcja prawa” to proces zachodzący w adresacie prawa. Poprzez recepcję realizuje on nakazane mu normy i traktuje jak własne ${ }^{151}$. Oczywiście, w kontekście tematu książki istotne będzie pierwsze znaczenie omawianego terminu, ograniczające zjawisko recepcji prawa związków wyznaniowych do ustawodawstwa.

Zagadnienie takiej recepcji w prawie polskim ma doniosły wymiar historyczny. Zakres tej recepcji jest znaczny ${ }^{152}$. Dotyczy to przykładowo instytucji prawnej, takiej jak wina, jako podstawy odpowiedzialności karnej. Ta instytucja, oparta na prawnej zasadzie „nemo puniatur sine culpa” („nikt bez winy nie może być ukarany"), obecnie wymieniana jest w art. I $\$ 3$ k.k. oraz kan. I32I $\$$ I KPK. Z prawa kanonicznego pochodzi też wiele zasad prawnych, mających swe źródło szczególnie w Liber sextus decretalium papieża Bonifacego VIII ${ }^{153}$. Dla przykładu można podać przepis $\mathrm{nr} 6 \mathrm{z}$ De regulis iuris ${ }^{154}$ : „Nemo potest ad impossibile obligari” („Nikt nie może być zobowiązany do niemożliwego”),

I49 Por. A. Rzepecki, Funkcjonowanie prawa kanonicznego w polskim porządku prawnym - zarys tematu, „Acta Erasmiana” 5 (2013), s. I84.

I50 Por. A. Tunia, Recepcja prawa wewnętrznego..., dz. cyt., s. 2I-27.

I5I Szeroko o tym zob. P. Kroczek, The Art of Legislation..., dz. cyt., s. 215-23I.

I52 Por. W. Uruszczak, Historia państwa i prawa polskiego, t. I: 966-I795, Warszawa 20Io, s. II5. Zob. szeroko o tym w A. Tunia, Recepcja prawa wewnętrznego..., dz. cyt.

I53 Bonifatio PP. viII, Liber sextus decretalium, 3.03.I298, [w:] Corpus Iuris Canonici, editio Lipsiensi secunda..., dz. cyt. vol. 2, kol. 933-II2I.

I54 Bonifatio PP. VIII, De regulis iuris, 3.03.I298, dz. cyt., kol. II22-II24. 
który jest obecny jako zasada w art. $387 \$$ I kodeksu cywilnego. Trybunał Konstytucyjny w uzasadnieniu wyroków z dnia 20 grudnia 1999 r. ${ }^{155}$ oraz z dnia 3 października 200I r. ${ }^{156}$ odwołał się do Dekretu Gracjana, a mianowicie do zasady leges instituuntur cum promulgantur ${ }^{\mathrm{I} 7}$ (por. can. 8 \ I CIC, kan. 7 K РК) zawartej teraz w art. 88 w Konstytucji Rp. Oczywiście, część tych elementów prawa zostało wcześniej przejętych przez prawo kanoniczne z prawa rzymskiego.

Z prawa kanonicznego określającego katalog świąt kościelnych wywodzą się normy ustalające $\mathrm{w}$ prawie polskim niektóre dni wolne od pracy. Ustawa z dnia I8 stycznia I95I r. o dniach wolnych od pracy $^{158}$ zawiera w art. I wykaz dni, które częściowo pokrywają się z katalogiem dni świątecznych z kan. I246 \$ I kodeksu łacińskiego (zob. art. I7 ust. I u.s.p.k.k, art. 9 ust. I Konkordatu). Można zauważyć, że przy wyliczeniu świąt katolickich, będących dniami wolnymi od pracy, użyto nazw świąt, które są w powszechnym kościelnym użyciu, np. „I stycznia - Nowy Rok” ma odpowiednik w postaci „Uroczystości Świętej Bożej Rodzicielki Maryi”, 6 stycznia określono ustawowo jako „Święto Trzech Króli”, a we wskazanym kanonie jest „Uroczystość Objawienia Pańskiego”, natomiast „Uroczystość Ciała i Krwi Chrystusa” określono w ustawie jako „dzień Bożego Ciała” ${ }^{159}$.

Obecnie zakres tej recepcji jest zależny od kwestii wzajemnego stosunku prawa państwowego i prawa związków wyznaniowych. W warunkach polskich ten problem ograniczony jest zazwyczaj do prawa kanonicznego ${ }^{160}$.

Stosowanie przez polskiego ustrojodawcę pojęć prawnych wypracowanych na gruncie religijnym, takich jak „godność człowieka” (art. 30 Konstytucji RP, zob. art. 3 k.k.) czy „dobro wspólne” (Preambuła oraz art. I, art. 82 Konstytucji $\mathrm{RP})$ nie stanowi wyraźnego dowodu na pełną recepcję prawa kanonicznego czy nauki Kościoła. Wszystko zależy od tego, czy pojęciom tym będzie nadawana

I55 Wyrok Trybunału Konstytucyjnego z dnia 20 grudnia 1999 r., K 4/99, Legalis nr 45630 .

I56 Wyrok Trybunału Konstytucyjnego z dnia 3 października 200 I r., K 27/oI, Legalis nr 50909 .

I57 Por. Decretum magistri Gratiani, dz. cyt., D.Iv, C.III.

I58 Ustawa z dnia I8 stycznia I95I r. o dniach wolnych od pracy (tekst jedn. Dz.U. z 2015 r. poz. 90).

I59 Por. P. Kroczek, Świętowanie w pedagogice prawa kanonicznego i prawa polskiego, „Polonia Sacra” 28 (2011), s. I69-187.

I60 Zob. np. M. Pietrzak, Prawo kanoniczne a państwowy porządek prawny, „Ruch Prawniczy, Ekonomiczny i Socjologiczny” 47 (1985) z. 2, s. I-2I; R. Sobański, Prawo kanoniczne a krajowy porzadek prawny, dz. cyt., s. 3-17. 
odpowiednia treśćc ${ }^{61}$. Także wprowadzenie przez ustawodawcę zasad prawnych, dla przykładu, zasady pomocniczości do prawa rodzinnego, jest raczej czynione nieintencjonalnie ${ }^{162}$.

Należy zauważyć, że zostały przedstawione relacje prawa związków wyznaniowych do państwowego, a nie odwrotne. To znaczy, że uznaje się prawo państwowe za dominujące $\mathrm{w}$ tych relacjach. Taki status quo tego prawa może mieć różne przyczyny.

\subsubsection{Ogólne zasady relacji prawa związków wyznaniowych do prawa państwowego w Rzeczypospolitej Polskiej}

Wspomniana wyżej fundamentalna zasada relacji państwa i kościoła lub innego związku wyznaniowego, czyli zasada niezależności i autonomii „obejmuje nie tylko płaszczyznę moralną, ale również prawną" ${ }^{163}$. Ma to dla omawianego problemu szczególne znaczenie.

Regulacje wewnętrzne tych organizacji zgodnie z prawem powstają poza kontrolą organów państwowych i nie wymagają przez nie zatwierdzenia, aby nabrać mocy obowiązującej ${ }^{164}$. Od tej zasady istnieją wyjątki. Zaliczyć należy do nich statut Wschodniego Kościoła Staroobrzędowego (art. I r.s.p.w.k.s.) i Muzułmańskiego Związku Religijnego (art. 2 u.s.p.m.z.r.). Zgodnie z prawem polskim wymagają one „uznania” przez władze polskie. W tym pierwszym przypadku, rzeczywiście, zgodnie z $\$$ io ust. 6 statutu Wschodniego Kościoła Staroobrzędowego uchwalanie statutu i jego zmian podlega zatwierdzeniu przez Urząd do spraw Wyznań. Jednak w tym drugim przypadku, czyli

I6I Por. W. Uruszczak, Recepcja prawa kanonicznego w obowiazującym prawie polskim, dz. cyt., s. I8.

I62 Zob. P. Kroczek, List do rodzin „Gratissimam sane” jako wskazówka dla prawodawstwa państwowego, [w:] Prawa dziecka: perspektywa Kościota, red. P. Kroczek, Kraków 2015, s. 8I-97 (Annales Canonici. Monographiae, 3); P. Kroczek, Does the Catholic Vision of the Principle of Subsidiarity Pertain to Polish Family Law?, „Ecumeny and Law" 3 (2015), s. 327-340.

I63 J. Krukowski, Kościelne prawo publiczne. Prawo konkordatowe, Lublin 2013 , s. I56.

I64 Por. M. Pietrzak, Prawo kanoniczne w polskim systemie prawnym, „Państwo i Prawo" (2006) z. 8, s. 3I. W literaturze przedmiotu podnosi się, że kościoły i inne związki wyznaniowe, które cieszą się indywidualną ustawą, mają pozycję uprzywilejowaną wobec zrzeszeń rejestrowych, których statuty podlegają przy rejestracji weryfikacji pod kątem zgodności z prawem polskim. Zob. A. Tunia, Recepcja prawa wewnętrznego..., dz. cyt., s. I47. 
związku muzułmanów, w praktyce wyjątek stał się ogólną zasadą. Statut tej organizacji powinien po nowelizacji uzyskać uznanie przez państwo w drodze rozporządzenia Rady Ministrów (art. 2 u.s.p.m.z.r.). W praktyce, jak zapisano zresztą w samym statucie, ,przesyłany jest do wiadomości ministra właściwego do spraw wyznań religijnych” ( $\$$ I ust. 5 SMZR2009). Takie rozwiązanie należy ocenić negatywnie.

Dodatkowo, źródła prawa wewnętrznego kościołów i innych związków wyznaniowych nie są wymieniane w katalogu źródeł prawa polskiego systemu prawnego (zob. art. 87 Konstytucji RP). Zasadniczo katalog ten jest katalogiem zamkniętym $^{165}$. W konsekwencji ich własne prawo, co do zasady, nie wywiera skutków na forum prawa państwowego i vice versa ${ }^{166}$.

Wiadomo jednakże nie wszystkie normy regulujące życie społeczne w Polsce pochodzą od samego państwa. Czasem sięga się do innych źródeł. Normy te mogą pochodzić także od wspólnot wyznaniowych, a to oznacza, że istnieją odstępstwa od ogólnej zasady ich nieskuteczności prawnej na forum prawa polskiego.

\subsection{Stosowanie prawa związków wyznaniowych na forum prawa polskiego}

\subsubsection{Modelowe ujęcie obecności prawa związków wyznaniowych w prawie polskim}

Niektóre obszary życia społecznego są uregulowane (często niezależnie i autonomicznie, a niekiedy w sposób skoordynowany ${ }^{167}$ ) zarówno przez prawo państwowe, jak i przez prawo związków wyznaniowych (causae mixtae). Zdarzają się też sytuacje, w których kościoły lub związki wyznaniowe pełnią funkcje publiczne, angażując się w rozmaite sfery działalności służącej zaspokajaniu

I65 Por. K. Działocha, Zamknięty system źródet prawa powszechnie obowiązującego w konstytucji i praktyce, [w:] Konstytucyjny system źródet prawa w praktyce, red. A. Szmyt, Warszawa 2005, s. 9.

I66 Zob. szerzej: A. Mezglewski, Opinia prawna dotycząca problemu obowiązywania prawa wewnętrznego związków wyznaniowych w obrocie prawnym, „Przegląd Prawa Wyznaniowego" 3 (20II), s. 25I-258.

I67 Jak w przypadku małżeństw zawieranych w formie religijnej, która rodzi skutki cywilne. Zob. A. Mączyński, Skutki cywilne matżeństwa kanonicznego w świetle konkordatu i prawa polskiego, [w:] Konkordat 1993. Dar i zadania dla Kościota i Polski, red. J. Dyduch, Kraków 1998, s. I7-40. 
potrzeb indywidualnych i zbiorowych, innych niż działalność związana ze sprawowaniem i szerzeniem kultu religijnego ${ }^{168}$. W tak szerokiej działalności dochodzi do zbiegu prawa państwowego i kanonicznego. Można zatem rozważać zagadnienie współdziałania norm pochodzących z tych porządków prawnych lub ich ewentualnej kolizji ${ }^{169}$.

W warunkach ustrojowych i prawnych Polski normy pochodzące z religijnego prawa nie działają autonomicznie i automatycznie na forum prawa polskiego. Polska to bowiem państwo suwerenne (Preambuła, Konstytucja RP). Normy religijne mogą oddziaływać w systemie prawa polskiego jedynie dzięki zezwoleniu, które daje prawo świeckie i w zakresie określonym przez to prawo.

Tu można zauważyć trzy modele obecności prawa związków wyznaniowych w prawie polskim. Model pierwszy dotyczy sytuacji, w której następuje odesłanie do prawa wewnętrznego kościoła lub związku wyznaniowego, jako podstawy do regulacji określonej dziedziny stosunków społecznych i oznacza obowiązywanie w państwowym porządku prawnym wybranej części norm prawa związków wyznaniowych. Jeżeli chodzi o ten model, to bywa tak, że państwo samo rezygnuje ze swojej kompetencji regulacyjnej w danym zakresie i wprost odsyła do związków wyznaniowych. Podstawą obowiązywania prawa związków wyznaniowych jest zatem wola organu państwowego (najczęściej organu ustawodawczego). Niekiedy państwo zawiesza działanie prawa przez siebie ustanowionego w danym zakresie i oddaje pole prawu konfesyjnemu. W ramach tego modelu można przypisać prawu związków wyznaniowych rolę dyrektyw interpretacyjnych ${ }^{170}$. Drugi model to recepcja prawa kanonicznego do obowiązującego porządku prawnego państwa na zasadzie lex specialis. Dzieje się to w sytuacjach, gdy kościół lub inne związki wyznaniowe podejmują działalność zgodną ze swoim powołaniem ${ }^{171}$. Trzeci model to wsparcie prawa państwowego przez prawo związków wyznaniowych w konkretnych przypadkach. Wydaje się,

I68 Zob. R. Mojak, Kościót a sprawy publiczne w demokratycznym państwie. Podstawy doktrynalne oraz zasady prawne wspótdziatania Kościota i państwa w sferze życia publicznego, [w:] Funkcje publiczne związków wyznaniowych..., dz. cyt., s. 59-96.

I69 Por. P. Kroczek, Prawo świeckie jako bariera komunikacyjna dla niektórych treści nauczania Kościota o matżenstwie i rodzinie, [w:] Rodzina podmiotem wychowania i kreatorem komunikacji spotecznej, red. N. Pikuła, Kraków 20Io, s. 33I-344.

I70 Por. A. Tunia, Recepcja prawa wewnętrznego..., dz. cyt., s. 45.

I7I Por. W. Uruszczak, Recepcja prawa kanonicznego w obowiąujacym prawie polskim, dz. cyt., s. Iо. 
że zwiększeniu efektywności obu praw mogą służyć szczególnie regulacje dotyczące małżeństwa lub rodziny ${ }^{172}$.

\subsubsection{Formy odesłania do prawa związków wyznaniowych}

Niezależnie od modelu obecności prawa związków wyznaniowych odesłanie z prawa polskiego do prawa związków wyznaniowych ma charakter bezpośredni lub niebezpośredni, czyli dorozumiany.

\subsubsection{Odesłanie bezpośrednie}

$\mathrm{Z}$ bezpośrednim odesłaniem mamy do czynienia wówczas, gdy norma wprost nakazuje zastosowanie prawa związków wyznaniowych. W tym przypadku obowiązywanie prawa związków wyznaniowych nie zależy od tego, czy dana materia jest objęta regulacją prawa państwowego czy też nie. Jeżeli jest objęta taką regulacją, to wówczas prawo związków wyznaniowych może regulować tę dziedzinę jako prawo obowiązujące pro foro externo. Jeżeli natomiast regulacji państwowej nie ma, to także pro foro externo dana dziedzina winna podlegać prawu związków wyznaniowych ${ }^{173}$.

\subsubsection{Odesłanie niebezpośrednie}

Odesłanie niebezpośrednie, czyli dorozumiane istnieje wówczas, gdy konstrukcja przepisów ustawy państwowej lub innego źródła norm może stwarzać potrzebę zastosowania prawa wewnętrznego związku wyznaniowego, mimo że przepisy państwowe nie zawierają wyraźnego odesłania ${ }^{174}$.

Odesłania te mają źródło w ustawach dotyczących kościołów i innych związków wyznaniowych, innych ustawach, występują również w orzeczeniach sądów czy umowach zawieranych pomiędzy rządem a kościołami lub

I72 Por. P. Kroczek, Prawo kanoniczne wsparciem dla polskiego prawa rodzinnego: teoretyczne podstawy i praktyczne przyktady, „Bielsko-Żywieckie Studia Teologiczne” I4 (2013), s. I3I-I45; P. Kroczek, Kanoniczne zakazy zwiąane z matżeństwem jako możliwość wsparcia ściagalności alimentów na dzieci, „Polonia Sacra” 29 (20II), s. I79-194.

I73 Por. W. Uruszczak, Recepcja prawa kanonicznego w obowiązującym prawie polskim, dz. cyt., s. I3.

I74 Por. A. Mezglewski, H. Misztal, P. Stanisz, Prawo wyznaniowe, dz. cyt., s. 65. 
związkami wyznaniowymi. Ich przedstawienie jest uzasadnieniem podjętego w książce tematu.

\subsubsection{Przykłady odesłań do prawa związków wyznaniowych}

\subsubsection{Konkordat}

Do prawa kanonicznego odsyłają artykuły Konkordatu. Dla przykładu w art. 5 państwo zapewnia Kościołowi katolickiemu swobodne i publiczne pełnienie jego misji, łącznie z wykonywaniem jurysdykcji oraz zarządzaniem i administrowaniem jego sprawami na podstawie prawa kanonicznego. Oczywiście nie oznacza to, że wszystkie czynności prawne dokonane na podstawie prawa kanonicznego są skuteczne na forum prawa polskiego, choć skuteczność czynności na forum prawa polskiego może być uzależniona od skuteczności czynności na forum prawa kanonicznego ${ }^{175}$.

Automatycznie w oparciu o art. 6 ust. I Konkordatu, w którym państwo uznaje, że „tworzenie właściwych Kościołowi struktur należy do kompetentnej władzy kościelnej”, utworzenie wymienionych w ustawie o stosunku państwa do Kościoła struktur administracyjnych (art. 7 ust. I) czy też struktur nieadministracyjnych (art. 8 ust. I), jeżeli jest skuteczne na forum prawa kanonicznego, powoduje, że te struktury nabywają osobność prawną na forum prawa polskiego.

Także obsadzanie urzędów kościelnych może być dokonywane w oparciu o prawo kanoniczne przez kompetentne władze kościelne (art. 7 ust. I Konkordatu). Osoby te na podstawie art. 7 ust. 3 ustawy są organami osób prawnych, czyli przedstawicielami ustawowymi uznanymi w prawie polskim.

Konkordat zawiera też dalsze szczegółowe postanowienia odwołujące się do prawa kanonicznego. Dotyczy to przykładowo nauczania religii. W art. I2 ust. 3 stanowi się, że „Nauczyciele religii muszą posiadać upoważnienie (missio canonica) od biskupa diecezjalnego. Cofnięcie tego upoważnienia oznacza utratę prawa do nauczania religii”. Zarówno nabycie, jak i utarta

I75 Por. M. Liśkiewicz, Skuteczność norm prawa kanonicznego w polskim porzadku prawnym na przyktadzie wybranych stosunków cywilnoprawnych z udziatem kościelnych osób prawnych, 20I3, licencjat kościelny dostępny w Bibliotece Uniwersytetu Papieskiego Jana Pawła II w Krakowie. 
misionis canonicae są regulowane wyłącznie przez prawo kanoniczne. Konkordat wprost odwołuje się do „przepisów i zarządzeń kościelnych”, gdy chodzi o treści nauczania i wychowania religijnego (art. I2 ust. 4).

\subsubsection{Ustawy wyznaniowe}

Ustawy wyznaniowe bardzo często przywołują prawo wewnętrzne w konkretnych sytuacjach. Oto niektóre z nich.

\subsection{Organizacja wewnętrzna}

Wspomniane akty normatywne odsyłają do prawa wewnętrznego przy regulowaniu organizacji wewnętrznej kościołów i innych związków wyznaniowych.

Można podać kilka przykładów: „Gminy żydowskie rządzą się w swoich sprawach własnym prawem wewnętrznym, określającym w szczególności organizację gmin żydowskich, uchwalanym przez walne zebranie Związku Gmin w porozumieniu z Radą Religijną Związku Gmin” (art. 3 ust. 2 u.s.p.g.w.ż.). Podobnie jest w Ustawie z dnia 20 lutego 1997 r. o stosunku Państwa do Kościoła Zielonoświątkowego w Rzeczypospolitej Polskiej - art. 4 ust. I: „Strukturę i organizację Kościoła określa Prawo Wewnętrzne”.

Tak jest również w przypadku art. 6 Ustawy z dnia I3 maja I994 r. o stosunku Państwa do Kościoła Ewangelicko-Augsburskiego: „Organizację wewnętrzną Kościoła określa Zasadnicze Prawo Wewnętrzne”.

\subsection{Kompetencje organów}

Inną sytuacją jest konieczność poznania zakresu kompetencji organów kościołów i innych związków wyznaniowych.

Ustawa z dnia 4 lipca I99I r. o stosunku Państwa do Polskiego Autokefalicznego Kościoła Prawosławnego w art. 6 ust. 4 stanowi, że „Kompetencje Soboru Lokalnego, Świętego Soboru Biskupów i Metropolity ustala Statut Wewnętrzny Kościoła, który uchwala Sobór Lokalny" ${ }^{176}$.

\subsection{Działalność osób prawnych}

Działalność osób prawnych działających jako osoby prawne także w oparciu o prawo polskie może być regulowana również przez prawo endogeniczne

I76 Po 1995 r. taki sobór się nie odbył. 
kościoła lub innego związku wyznaniowego. Ustawodawca polski dopuszcza taką sytuację.

Tak jest w przypadku np. art. 38 ust. 5 i ust. 6 Ustawy z dnia 17 maja I989 r. o stosunku Państwa do Kościoła Katolickiego, gdzie przy regulacjach działalności charytatywno-opiekuńczej Kościoła ustawa stanowi, że „Zakony prowadzą działalność charytatywno-opiekuńczą w zakresie określonym w ich statutach lub odpowiednich aktach wewnętrznych” oraz „Działalność charytatywno-opiekuńczą mogą prowadzić organizacje katolickie w zakresie określonym w ich statutach”. Podobnie w art. 38 ust. 5: „Zakony prowadzą działalność charytatywno-opiekuńczą w zakresie określonym w ich statutach lub odpowiednich aktach wewnętrznych”.

\subsection{Nazewnict wo osób prawnych}

Ustawowe nazwy osób prawnych pochodzą oczywiście z prawa kościoła lub innego związku wyznaniowego. Jednakże państwo uznaje zmianę tej nazwy, jeżeli została dokonana przez przepisy wewnątrzkościelne (np. art. 3 ust. 5 u.s.p.k.s.m., art. 6 ust. 4 u.s.p.e-m.).

Zmiany te, na wniosek organu kościoła lub związku wyznaniowego, kompetentny minister, np. minister spraw wewnętrznych i administracji (art. 5 ust. 5 u.s.p.k.s.m.), ogłasza w Dzienniku Urzędowym Rzeczypospolitej Polskiej „Monitor Polski”.

\subsubsection{Inne ustawy}

Wiele ustaw odsyła do porządku prawnego kościołów i innych związków wyznaniowych.

Przykładowo, ustawy odwołują się do prawa związków wyznaniowych w definiowaniu terminów takich, jak:

I. „duchowny” - art. I06 $\$ 2$ k.k.w., art. $217 \$ 6$ k.k.w., art. 178 nr 2 k.p.k., art. 26I $\$ 2$ k.p.c.,

2. „osoba zakonna” - art. I2 ust. I u.g.w.s.w.,

3. „nabożeństwo” - art. 88b nr 3 k.k.w., art. I06 $\$$ I k.k.w., art. I06 $\$ 4$ k.k.w., art. I43 $\$ 3$ nr 3 k.k.w., art. 2 I2b $₫$ I nr 3 k.k.w.,

4. „władza duchowna” - art. Io6 $\$ 4$ k.k.w.,

5. „spowiedź” - art. $73 a \$ 4$ k.k.w., art. 178 nr 2 k.p.k., art. 26I $\$ 2$ k.p.c.

Ma to miejsce w odniesieniu do organizacji kościelnych. Mogą być one tworzone oraz prowadzić działalność wyłącznie w ramach określonych prawem 
kanonicznym. W odniesieniu do nich nie stosuje się przepisów ustawy - Prawo o stowarzyszeniach ${ }^{177}$. Oznaczać to winno także uznanie w państwowym porządku prawnym wynikającej z prawa kanonicznego osobowości prawnej tych organizacji, co najmniej w ramach określonych przez art. 34 ust. 3 Ustawy z dnia I7 maja 1989 r. o stosunku Państwa do Kościoła katolickiego.

Ustawa z dnia 3I stycznia 1959 r. o cmentarzach i chowaniu zmarłych ${ }^{178}$ przyznaje kompetencje właściwej władzy kościelnej co do decydowania o założeniu, rozszerzeniu lub zamknięciu cmentarza wyznaniowego (art. I ust. 3 i ust. 5 u.c.). „Utrzymanie cmentarzy wyznaniowych i zarządzanie nimi należy do związków wyznaniowych" (art. 2 ust. 2 u.c.), tak więc cmentarze wyznaniowe podlegają administracji kościoła lub innego związku wyznaniowego.

W przypadku cmentarzy katolickich podmioty i zasady tej administracji określa prawo kanoniczne. W kodeksie w kan. I24I I i $\$ 2$ stanowi się, że to parafie oraz instytuty zakonne mogą mieć własny cmentarz, również inne osoby prawne albo rodziny mogą posiadać cmentarz lub grobowiec. Szczegółowe przepisy w tym zakresie oraz te dotyczące porządku na cmentarzach, zwłaszcza utrzymania i ochrony ich sakralnego charakteru, powinny być ustanowione przez prawo partykularne (kan. I243 KPK).

\subsubsection{Rozporządzenia}

Rozporządzenie Ministra Edukacji Narodowej z dnia I4 kwietnia 1992 r. w sprawie warunków i sposobu organizowania nauki religii w publicznych przedszkolach i szkołach ${ }^{179}$ odwołuje się do prawa związków wyznaniowych, gdy uzależnia zatrudnienie nauczyciela religii wyłącznie na podstawie imiennego pisemnego skierowania do danego przedszkola lub szkoły, wydanego przez I) w przypadku Kościoła katolickiego - właściwego biskupa diecezjalnego, 2) w przypadku pozostałych kościołów oraz innych związków wyznaniowych właściwe władze zwierzchnie tych kościołów i innych związków wyznaniowych $(\$ 5$ ust. I). Podobnie w $\$ 8$ ust. I, $\$$ II ust. I i ust. 3 ministerstwo używa terminów prawnych „biskup diecezjalny” i „władza zwierzchnia”, odsyłając po desygnat nazw do prawa związków wyznaniowych.

I77 Ustawa z dnia 7 kwietnia 1989 r. Prawo o stowarzyszeniach (tekst jedn. Dz.U. z 2015 r. poz. 1393 z późn. zm.).

I78 Tekst jedn. Dz.U. z 2015 r. poz. 2126 z późn. zm. [dalej: u.c.]

179 Dz.U. z 1992 r. Nr 36, poz. I55 z późn. zm. 


\subsubsection{Akty prawa miejscowego}

Ilekroć organy powołane do uchwalania aktów prawa miejscowego posługują się pojęciami religijnymi bez bliższego ich określenia, czyli przykładowo poprzez podanie definicji legalnej, także odsyłają do prawa związków wyznaniowych w celu ustalenia treści tych terminów.

Przykładowo Uchwała Nr xxxIII/354/2013 Rady Miejskiej w Toszku z dnia 26 czerwca $2013 \mathrm{r}$. w sprawie zasad usytuowania miejsc sprzedaży i podawania napojów alkoholowych na terenie Gminy Toszek ${ }^{180}$ nie podaje definicji użytego terminu „obiekt kultu religijnego”. Zasadne jest zatem, aby organy administracji publicznej sięgnęły przy wykładni tego zwrotu do prawa związków wyznaniowych, respektując konstytucyjną swobodę władz religijnych w wyznaczaniu katalogu miejsc i obiektów kultu religijnego ${ }^{181}$.

\subsubsection{Orzecznictwo}

$\mathrm{Na}$ wskazane sytuacje wskazuje także orzecznictwo, nakazując uregulowanie na forum prawa polskiego pewnych sytuacji prawnych, których uczestnikiem jest kościół lub inny związek wyznaniowy, poprzez zastosowanie norm pochodzących z własnego, czyli wewnętrznego prawa tych organizacji.

Dla pewnej egzemplifikacji można podać Postanowienie Sądu Najwyższego - Izba Cywilna z dnia I2 stycznia 20II r. ${ }^{\mathrm{I} 82}$, z tezą: ,zakres kompetencji organów oraz reprezentację parafii Kościoła Ewangelicko-Augsburskiego w Rzeczypospolitej Polskiej określa Zasadnicze Prawo Wewnętrzne tego Kościoła oraz jego Regulamin Parafialny".

I80 „Dziennik Urzędowy Województwa Śląskiego” poz. 4736.

I8I Wprawdzie Wyrok Naczelnego Sądu Administracyjnego z dnia 8 stycznia 2008 r., II GSK 286/07, Legalis nr 96023 stanowi, że „Błędne jest stanowisko organów administracji, które dla dokonania legalnej wykładni aktu prawa miejscowego sięgnęły tylko do aktów niebędących źródłami powszechnie obowiązującego prawa w Polsce", jednakże teza ta nie obejmuje subsydiarnego użycia egzogenicznych źródeł norm. Zob. A. Januchowski, Glosa do wyroku NSA z dnia 8 stycznia 2008, II GSK 286/07, "Orzecznictwo Sądów Polskich” (2009) z. 2, poz. I8 oraz B. Rakoczy, Glosa do wyroku NSA z dnia 8 stycznia 2008, II GSK 286/07, „Orzecznictwo Sądów Polskich” (2009) z. 2, poz. I8.

I82 Postanowienie Sądu Najwyższego - Izba Cywilna z dnia I2 stycznia 20II r., I CSK I82/IO, Legalis nr 309866. 
Kolejnym przykładem może być Wyrok Sądu Najwyższego - Izba Cywilna z dnia 24 marca 2004 r. $^{183}$, z tezami, iż , ustawa z dnia I7 maja I989 r. o stosunku Państwa do Kościoła Katolickiego w Rzeczypospolitej Polskiej (Dz.U. Nr 29, poz. I54 z późn. zm.) uznała kompetencję proboszczów do reprezentowania parafii w stosunkach majątkowych z osobami trzecimi w sposób i na zasadach określonych w kodeksie prawa kanonicznego”, oraz że „ważność dokonanych przez proboszcza czynności przekraczających granice i sposób zwyczajnego zarządzania, określonych w statucie lub stosownym akcie biskupa diecezjalnego, zależy od uprzedniego pisemnego upoważnienia ordynariusza, a czynności o charakterze alienacji dóbr - od zezwolenia władzy określonej w kanonie I292 kodeksu prawa kanonicznego".

W wyroku z dnia 26 marca 1993 r. Sąd Antymonopolowy ${ }^{184}$ zawarł tezę, iż „Wzajemne stosunki pomiędzy osobą prawa kościelnego a podmiotem gospodarczym przy organizowaniu czynności kultu publicznego kościoła, w tym także w zakresie organizacji religijnej uroczystości pogrzebowej, podlegają regulacji powszechnie obowiązującej ustawy z dnia 24 lutego 1990 r. o przeciwdziałaniu praktykom monopolistycznym, chyba że przepisy tej ustawy są odmienne (sprzeczne) od własnego prawa kościoła, o którym mowa w art. 2 i art. 3 ust. 2 ustawy z dnia 17 maja I989 r, stosunku Państwa do Kościoła Katolickiego w Rzeczypospolitej Polskiej” ${ }^{185}$.

Z kolei w Wyroku Wojewódzkiego Sądu Administracyjnego w Opolu z dnia 8 kwietnia 2015 r. $^{186}$ sąd nie podzielił stanowiska dyrektora Izby Skarbowej w Opolu o braku podstaw do stosowania w badanej sprawie regulacji dotyczących Kościoła katolickiego, w tym prawa kanonicznego, lecz stwierdził, że „Niewątpliwie przy wykładaniu pojęć i unormowań regulujących specyficzne i właściwe tylko dla instytucji Kościoła Katolickiego rozwiązania prawne przepisy te muszą być rozważane, co wynika z art. I Konkordatu, wprowadzonego do polskiego systemu prawnego już po wejściu w życie ustawy o stosunku

I83 Wyrok Sądu Najwyższego - Izba Cywilna z dnia 24 marca 2004 r., IV CK IO8/03, Legalis nr 67840 .

I84 Wyrok Sądu Antymonopolowego z dnia 26 marca I993 r., XVII Amr 46/92, Legalis nr 45I23.

I85 Odmiennie jednak: Wyrok Sądu Antymonopolowego z dnia 23 kwietnia 20or r., Xvir Ama 49/oo, Legalis nr 656r5; Wyrok Sądu Okręgowego - Sądu Ochrony Konkurencji i Konsumentów z dnia I2 stycznia 2006 r., XVII Ama I05/04, Legalis nr 7880I.

I86 Wyrok Wojewódzkiego Sądu Administracyjnego w Opolu z dnia 8 kwietnia 2015 r., I SA/Op 24/I5, Legalis nr I272575. 
Państwa do Kościoła Katolickiego (por. wyrok NSA z dnia 26 marca 2OI3 r., I FSK 786/12, art. 2 i art. 3 ustawy o stosunku Państwa do Kościoła Katolickiego)”.

Trzeba jednak zaznaczyć, że orzecznictwo polskich sądów nie jest jednobrzmiące. Analiza judykatów pozwala na stwierdzenie, że sądy nie wypracowały jednolitego podejścia do roli prawa kościołów i innych związków wyznaniowych w regulowaniu stosunków prawnych na forum świeckim, ani skuteczności powyższych norm w prawie polskim, czy też skutków prawnych naruszenia tych norm ${ }^{187}$.

\subsubsection{Umowy}

Do endogenicznego prawa związków wyznaniowych odsyłają także umowy pomiędzy państwem a kościołami lub innymi związkami wyznaniowymi.

Jako przykład można podać załącznik do Obwieszczenia Ministra Spraw Zagranicznych z dnia 29 lipca 1999 r. o wykonaniu Konkordatu między Stolicą

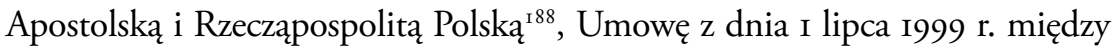
Rządem Rzeczypospolitej Polskiej a Konferencją Episkopatu Polski w sprawie statusu prawnego szkół wyższych zakładanych i prowadzonych przez Kościół Katolicki, w tym uniwersytetów, odrębnych wydziałów i wyższych seminariów duchownych, oraz w sprawie trybu i zakresu uznawania przez Państwo stopni i tytułów nadawanych przez te szkoły wyższe. Odniesienie do prawa kościelnego znajduje się w $\$ 7$ ust. 3: „Alumni wyższych seminariów duchownych, prowadzących sześcioletnie studia zgodnie z wymaganiami prawa kościelnego, mogą uzyskiwać tytuł zawodowy magistra kierunku «teologia» na podstawie umów o współpracy zawartych w oparciu o Konstytucję Apostolską Sapientia Christiana z kościelnymi szkołami wyższymi oraz z uczelniami państwowymi, w których strukturze znajdują się wydziały teologii, posiadającymi prawo prowadzenia studiów magisterskich na tym kierunku”. Natomiast w $\$ 8$ zapisano, że „Państwo uznaje kościelne stopnie naukowe doktora i doktora habilitowanego, nadane przez kościelne szkoły wyższe" - implicite nadane zgodnie także z prawem kanonicznym. Placówki te zarządzane są bowiem także w oparciu o ustawy kościelne.

I87 Zob. szerzej to tym: B. Rakoczy, Prawo kanoniczne w orzecznictwie sąów polskich, [w:] Prawo wyznaniowe w Polsce (I989-2009)..., dz. cyt., s. 275-283; M. Pietrzak, Prawo wewnętrzne (kanoniczne) Kościotów i związów wyznaniowych w polskim systemie prawnym, dz. cyt., s. I44-I5O.

I88 Dz.U. Nr 63, poz. 727. 


\subsubsection{Rozstrzygnięcia nadzorcze}

Interesujące rozstrzygnięcie nadzorcze odwołujące się do prawa kanonicznego wydał wojewoda dolnośląski dnia I marca 2010 r. ${ }^{189}$. Teza tej decyzji brzmi: „Rada Miejska nie posiada kompetencji do podjęcia uchwały w sprawie ustanowienia Św. Piotra patronem Miasta, nie jest to bowiem zaspokajanie zbiorowych potrzeb wspólnoty. Dodatkowo należy wziąć pod uwagę fakt, że zgodnie z art. 8 ust. 2 Konkordatu z dnia 28 lipca 1993 r. między Stolicą Apostolską i Rzeczpospolitą Polską (Dz.U. z 1998 r. Nr 5I, poz. 318), organizowanie kultu publicznego należy do władz kościelnych. Ustanowienie patrona Miasta związane jest z kwestiami religijnymi, a nie prawnymi. Samo ustanowienie patrona, określane przez władze kościelne mianem ustanowienia Patrona u Boga, należy do kompetencji Kongregacji Kultu Bożego i Dyscypliny Sakramentów przy Stolicy Apostolskiej”. Takie rozwiązanie jest słuszne. Jedyne zastrzeżenie, jakie można podnieść, to takie, że ustanowienie patrona miasta związane jest nie tylko z kwestiami religijnymi, ale i prawnymi - kanonicznymi. Jednakże ani co do materii, ani co do procedury sprawy te nie podlegają prawu polskiemu.

\subsubsection{Porozumienia}

Porozumienie z dnia 6 września 2000 r. pomiędzy Konferencją Episkopatu Polski oraz Ministrem Edukacji Narodowej w sprawie kwalifikacji wymaganych od nauczycieli religii ${ }^{190}$ także zawiera odesłanie do prawa kanonicznego. W dokumencie tym użyto terminów, do których zdefiniowania konieczne jest posłużenie się prawem kanonicznym: „osoba świecka” i „osoba zakonna”, „alumn seminarium duchownego”, „zakonne seminarium duchowne”.

Podobne odesłania do prawa kanonicznego są obecne w analogicznym porozumieniu ministra edukacji narodowej z Zarządem Kościoła Adwentystów Dnia Siódmego z dnia I3 lutego 1995 r. ${ }^{191}$, czy też w Porozumieniu pomiędzy

I89 Rozstrzygnięcie nadzorcze Wojewody Dolnośląskiego dnia I marca 20 Io r., NK-II.AL4.09II-5/IO, Legalis nr 544325.

I90 „Dziennik Urzędowy Ministra Edukacji Narodowej” Nr 4, poz. 20.

I9I Porozumienie pomiędzy Zarządem Kościoła Adwentystów Dnia Siódmego oraz Ministrem Edukacji Narodowej z dnia I3 lutego I995 r. w sprawie kwalifikacji zawodowych wymaganych od nauczycieli religii („Dziennik Urzędowy Ministra Edukacji Narodowej” Nr 3, poz. 7). 
Naczelną Radą Kościoła Zielonoświątkowego w Rzeczypospolitej Polskiej oraz Ministrem Edukacji Narodowej z dnia I2 lipca 20I2 r. w sprawie kwalifikacji zawodowych wymaganych od nauczycieli religii ${ }^{192}$.

2.14. Wniosek

W podsumowaniu tego rozdziału można jasno i dobitnie stwierdzić: prawo kościołów i innych związków wyznaniowych to prawdziwe prawo, lecz odmienne od prawa polskiego. Istnieje potrzeba, aby prawo związków wyznaniowych leżało w optyce organów władzy publicznej w Rzeczypospolitej Polskiej i ich działań. Stąd też konieczność znajomości tego prawa.

I92 Porozumienie pomiędzy Naczelną Radą Kościoła Zielonoświątkowego w Rzeczypospolitej Polskiej oraz Ministrem Edukacji Narodowej z dnia I2 lipca 20 I2 r. w sprawie kwalifikacji zawodowych wymaganych od nauczycieli religii („Dziennik Urzędowy Ministra Edukacji Narodowej” poz. I4). 


\section{Klauzule generalne w endogenicznym prawie kościołów i innych związków wyznaniowych}

Prawo powinno być jasne dla jego użytkowników. To stwierdzenie może być rozumiane na kilka sposobów. „Prawo jasne” może oznaczać: jasność norm prawnych, jasnośćaktu normatywnego, jasność systematyzacji aktów prawnych, czy też jasność systemu prawnego ${ }^{\mathrm{I}}$. Niezależnie jednak od precyzyjnego rozumienia przedmiotowego terminu pewne jest to, że „jasność prawa” jest jedną z najbardziej istotnych jego cech i warunków prawdziwości lub autentyczności prawa².

Z kolei „jasny tekst prawny” to tekst posiadający cechy „należytej poprawności, precyzji i jasności przepisów prawnych. Przepisy powinny być konstruowane poprawnie z punktu widzenia językowego i logicznego [...]"3. Takie cechy aktu normatywnego pozwalają jednoznacznie na kwalifikację stanu faktycznego z punktu widzenia obowiązującego prawa oraz dają pewną odpowiedź na pytania: kto, w jakich warunkach i w jaki sposób ma prawo lub obowiązek się zachowaćt. Stanowienie właśnie takich aktów normatywnych jest jednym z najistotniejszych założeń i jednocześnie postulatów dotyczących prawodawcy.

Realizacja powyższego postulatu nie wyklucza stosowania przez prawodawcę pojęć nieostrych, zwrotów niedookreślonych czy też klauzul generalnych ${ }^{5}$. Na-

I Por. P. Kroczek, The Art of Legislation..., dz. cyt., s. I34.

2 Por. L. Fuller, The Morality of Law, dz. cyt., s. 63.

3 Wyrok Trybunału Konstytucyjnego z dnia 2I marca 200I r., K 24/oo, Legalis nr 49669. W obrębie prawa polskiego zasady tej poprawności formułuje Rozporządzenie Prezesa Rady Ministrów z dnia 20 czerwca 2002 r. w sprawie „Zasad techniki prawodawczej" (tekst jedn. Dz.U. z 2016 r. poz. 283).

4 Por. K. Opałek, J. Wróblewski, Prawo. Metodologia, filozofia, teoria prawa, Warszawa I991, s. 253-254.

5 Zob. Wyrok Trybunału Konstytucyjnego z dnia 2I marca 200I r., K 24/00, Legalis nr 49669 . 
leży podkreślić, że „posługiwania się w prawie tego typu pojęciami nieostrymi nie można a priori traktować jako uchybienia legislacyjnego. Często bowiem skonstruowanie określonej normy prawnej przy ich pomocy stanowi jedyne rozsądne wyjście" ${ }^{6}$. Jednocześnie, gdy są one błędnie zastosowane, mogą stanowić zagrożenie dla praworządności`. Taką możliwość należy zawsze mieć na uwadze.

\subsection{Definicja klauzul generalnych}

W prawie polskim nie istnieje definicja terminu „klauzula generalna”. Nie ma jej także w prawie kościołów i innych związków wyznaniowych o uregulowanym przez ustawy stosunku do państwa polskiego.

Opierając się na nauce prawa, można powiedzieć, że według przeważającego w polskiej doktrynie poglądu dostosowanego do potrzeb rozważań skupionych na prawie związków wyznaniowych, klauzule generalne są to zwroty celowo niedookreślone lub nieostre, umieszczane w tekście normatywnym jako część przepisu, odsyłające do pozaprawnego systemu aksjologicznego, którego treść podlega konkretyzacji w procesie stosowania prawa'. System aksjologiczny w tym przypadku to system reguł i ocen zwykle niesformalizowany odzwierciedlający przyjęte powszechnie w danej wspólnocie religijnej lub głoszone oficjalnie przez kościół lub inny związek wyznaniowy normy religijne, czyli normy głównie o charakterze doktrynalno-moralnym, lecz także etycznym, kulturowym i ogólnoludzkim.

6 Uchwała Trybunału Konstytucyjnego z dnia 6 listopada I99I r., w 2/91, Legalis nr IOIO4.

7 Por. A. Wallkamm, Generalklauseln - Normen im Spannungsfeld von Flexibilität und Rechtsstaatswidrigkeit. Über das Verhältnis von Recht und Politik, „Rechtstheorie” 39 (2008) No. 4, s. 507.

8 Prawodawca polski posługuje się tym wyrażeniem w $\$$ I55 ust. I załącznika do Rozporządzenia Prezesa Rady Ministrów z dnia 20 czerwca 2002 r. w sprawie „Zasad techniki prawodawczej" (tekst jedn. Dz.U. z 2016 r. poz. 283).

9 Por. np. J. Czarzasty, Przyczynek do problematyki klauzul generalnych, „Państwo i Prawo” (1978) z. 5, s. 86; Z. Ziembiński, Problemy podstawowe prawoznawstwa, Warszawa 1980, s. 242; Z. Radwański, Prawo cywilne - część ogólna, Warszawa 2003, s. 51; W. Gromski, Klauzule generalne, [w:] A. Bator i inni, Wprowadzenie do nauk prawnych. Leksykon tematyczny, Warszawa 2008, s. I88; Z. Radwański, M. Zieliński, Uwagi „de lege ferenda” o klauzulach generalnych w prawie prywatnym, „Przegląd Legislacyjny” (200I) nr 2, s. 16; L. Leszczyński, Tworzenie generalnych klauzul odsytających, Lublin 2000, s. 25 . 
System ten ma zwykle charakter normatywny. W tym przypadku normatywność systemu aksjologicznego rozumiana jest jako jego funkcja polegająca na wyznaczaniu granic zachowań lub wzoru, względnie etosu zachowań. Wzór ten często ma charakter asymptotyczny, czyli przewiduje się pewną niemożliwość jego pełnej realizacji. Tak jest przykładowo w klauzulach generalnych, takich jak perfectio christiana („,chrześcijańska doskonałość) z kan. 303 KPK czy perfectio evangelica („ewangeliczna doskonałość”) z kan. 725 KPK.

Normatywność aksjologicznego systemu nie stawia podmiotu w sytuacji right and duty - tę rezerwuje się zwykle normom stricte prawnym ${ }^{\mathrm{IO}}$. Stawia ona natomiast podmiot w sytuacji imperatywu etycznego lub moralnego, czy też powinności religijnej, prawidłowości zachowania lub postawy czy też nawet, ujmując sprawę szeroko, celowości określonego postępowania ze względu na przynależność do określonego kościoła lub innego związu wyznaniowego lub też ze względu na osobistą wiarę członka religijnej wspólnoty.

Odesłania z klauzul generalnych kierują do:

I. zasad zawartych w księgach uznawanych za święte: „zasad biblijnych” (art. 7 ust. I pkt a PWKE-M), ,zasad ewangelicznych” (\$ I5 SKKM), „zasad zawartych w Koranie” (\$ 3 ust. I nr 3 SMZR2009) względnie „zasad zawartych w Koranie i Sunnie" (\$24 pkt I SMZr2009),

2. zasad będących treścią nauczania określonego kościoła lub innego związku wyznaniowego: principia doctrinae catholicae („zasad doktryny katolickiej”) (kan. 8IO $\$ 2 \mathrm{KPK}$ ), principia ab Ecclesia tradita („zasad podanych przez Kościół”) (kan. I286 pkt I KPK), „Zasad Kościoła” (art. 6 PWKE-R), „zasad religii karaimskiej” (\$35 lit. b sKzR), „Zasad baptyzmu” (art. 4 ZPWKCHв), ,zasad wyznania ewangelicko-reformowanego" (art. II, art. 35 ust. I, art. 36 PW KE-R), „zasad wiary Kościoła” (art. 5 ust. 2 ZPWкснв), „etyki Kościoła” (\$ 8 ust. I ZPWKE-A), „Zasad miłości bliźniego i miłosierdzia wynikających z judaizmu” (art. 6 pkt 2 Pwwwż), „zasad religijnych i moralnych judaizmu” (art. 9 pkt I Pwwwż), „zasad i tradycji judaizmu” (art. 33 ust. 4 Pwwwż), „ducha judaizmu” (art. 6 pkt 9 Pwwwż), „zasad religii islamu” ( $\$ 2$ pkt 3 SMZR2009), „zasad nauki islamu” ( $\$ 24$ pkt I SMZR2009), „zasad religii muzułmańskiej” ( $\$ 44$ pkt 3 SMZR2009);

3. ogólnych zasad religijnych, czyli zasad uniwersalnych dla religii jako takiej lub zasad określonej grupy wyznań. Należy tu zaliczyć odesłania do: „zasad życia religijnego” (art. I5 ust. I Pwwwż), „zasad wiary” (art. 5 ust. I oraz 
art. 49 ust. I ZРWкснв), normae vitae christianae („zasad życia chrześcijańskiego”) (kan. 767 I KPK), „chrześcijańskiego sposobu życia” (kan. 50 $\$ 2$ pkt b PWKP), „Zasad moralności chrześcijańskiej” (art. 4, art. 90, art. 93 PWKE-M).

Wydaje się, że ogólne zasady religijne z punktu 3 należy zawsze odczytywać w kontekście konkretnego związku wyznaniowego, z którego prawa pochodzą te klauzule. Stąd też trudno jest precyzyjnie określić treść tych zbiorów zasad i odróżnić zasady związane z nauczaniem określonego kościoła (punkt 3) lub innego związku wyznaniowego od ogólnych zasad religijnych (punkt 2).

Niekiedy odesłania nie są bezpośrednio skierowane do systemu aksjologicznego związanego z religią, lecz są z nią organicznie związane, np. odesłanie do „zasad życia przodków” (art. 6 pkt 9 Pwwwż). Odesłania religijne charakterystyczne dla prawa religijnego nie wykluczają odesłań do uniwersalnej aksjologii, np. do „zasady niezbędnej oszczędności i hierarchii potrzeb” (kan. I46 $\$ 2$ PWKP).

W klauzuli generalnej odsyłającej do systemów ocen, norm i wartości związanych z religią organ stosujący prawo otrzymuje kompetencję do posługiwania się ocenami i regułami religijnymi. To oczywiście zwiększa jego luz decyzyjny. Dzięki temu prawo w konkretnej sytuacji życiowej uwikłanej religijnie może być z punktu widzenia danego związku religijnego prawem słusznym i wypełniać mensis legislatoris, którym ostatecznie jest realizacja misji danego związku wyznaniowego $^{\text {II }}$.

Należy ponadto zwrócić uwagę na przypadki pokrywania się elementów systemu aksjologicznego, do którego odsyłają klauzule generalne, z elementami systemów ściśle prawnych. Skutkuje to zgodnością treściową norm prawnych i moralnych. To zjawisko często występuje w kontekście prawa związków wyznaniowych. Prawo religijne bowiem jest zazwyczaj, jak to pokazano w rozdziale II niniejszej książki, elementem życia kościoła lub innego związku wyznaniowego, silnie związanym z doktryną religijną i moralnością głoszoną przez te religijne zrzeszenia.

Podana wyżej definicja klauzul generalnych, choć zawiera elementy powszechnie przyjmowane w doktrynie prawniczej, może być nie w pełni zgodna ze stanowiskiem świeckiej jurysprudencji. Jak wspomniano, została ona

II Zob. P. Kroczek, Co prawodawca miat na myśli? - czyli czym jest „mens legislatoris” i gdzie jej szukać?, „Annales Canonici” 3 (2007), s. I87-198. 
opracowana z uwzględnieniem specyfiki prawa, którego dotyczy, czyli prawa religijnego.

Koniecznie trzeba także zaznaczyć, że definicja ta nie pasuje w pełni do tych systemów prawa religijnego, których integralną częścią są zasady doktrynalno-moralne. Tak jest w przypadku prawa kanonicznego, które zawiera nie tylko treści normatywne o pochodzeniu pozytywistycznym, ale zbiera w organiczną całość i ustawy, i doktrynalno-moralne nauczanie Kościoła. W tym kontekście może pojawić się wątpliwość, czy klauzule generalne mają charakter odsyłający poza system tego prawa.

Jednakże z powodu konieczności uwzględnienia systemów prawnych wszystkich kościołów i związków religijnych, które mają własną ustawę, a które to systemy takiej cechy agregacyjnej nie wykazują, oraz dla realizacji celu książki, jakim jest przybliżenie prawa religijnego przedstawicielom doktryny prawa polskiego, konieczne było odwołanie się do pojęć z polskiego prawoznawstwa.

W celu uporządkowania terminologii należy dodać, że terminy takie, jak „klauzula generalna”, „klauzula generalna klasyczna”, „klauzula odsyłająca”, „klauzula generalna funkcjonalna”, choć niekiedy rozróżniane w polskiej doktrynie prawniczej, są w niniejszym studium zaliczane po prostu do „klauzul generalnych".

\subsection{Czym nie są klauzule generalne?}

Dla jeszcze większej jasności klauzule generalne trzeba odróżnić od:

I. zwrotów niedookreślonych,

2. zwrotów nieostrych,

3. zwrotów szacunkowych,

4. zwrotów ocennych,

5. odesłań do prawa (związków wyznaniowych lub państwowego),

6. odesłań do sformalizowanych normatywnych systemów pozaprawnych,

7. prawnych zwyczajów.

W polskiej nauce prawa jest to powszechnie obowiązujące rozróżnienie ${ }^{\mathrm{I2}}$.

I2 Por. Z. Radwański, M. Zieliński, Uwagi „de lege ferenda” o klauzulach generalnych..., dz. cyt., s. II. 


\subsubsection{Zwroty niedookreślone}

Zwrot niedookreślony to taka nazwa - a nazwa jest to wyraz albo wyrażenie rozumiane jednoznacznie i nadające się na podmiot lub orzecznik orzeczenia imiennego w zdaniu ${ }^{13}$ - której sens, znaczenie, treść nie jest dokładnie określona. Słownikowa definicja takiej nazwy nie stanowi zespołu konstytutywnych cech tego zwrotu lub też stanowi zespół cech konstytutywnych danego zwrotu, ale przynajmniej jedna z tych cech jest niediagnostyczna, to znaczy taka, że trudno jest jednoznacznie stwierdzić, czy można ją przypisać danemu przedmiotowi czy też nie ${ }^{\mathrm{I}}$. Niedookreśloność to zatem cecha, która dotyczy znaczenia zwrotów. Ma ona charakter językowy, a po części również logiczny, a więc dotyczy raczej treści wyrażenia ${ }^{\text {Is }}$. Niedookreśloność zwrotów pociąga za sobą ich nieostrość.

Zwrotem niedookreślonym występującym w prawie kanonicznym jest wyraz oboedientia (niekiedy obsequium), czyli „posłuszeństwo”. Nie sposób za pomocą definicji słownikowej wyrazu określić, przykładowo, zakresu posłuszeństwa ${ }^{16}$. Występuje on przykładowo w kodeksie prawa kanonicznego z 1983 r. kilka razy w różnych wyrażeniach: voluntaria oboedientia (,dobrowolne posłuszeństwo”) (kan. 6I8), devoto obsequio („uległe posłuszeństwo”) (kan. 678 \$ I). Jednakże wyrażenie religiosum obsequium (,religijne posłuszeństwo”) (kan. 752 i kan. 753) jest klauzulą generalną. Do znalezienia jego sensu nie trzeba bowiem ani doprecyzować jego znaczenia ani też kwalifikować wielkości, lecz należy odwołać się do wartości, jaką jest dla wspólnoty wierzących jedność we wierze.

Niedookreślonym zwrotem jest także nazwa „okazywanie pomocy wzajemnej” (\$ II2 PSKE-A), „szczera chęć służenia Kościołowi” (kan. 9I \$4 pkt b PWKP), „roztropność duszpasterska” (kan. $79 \$ 3$ PWKP), „służba duchowa i materialna na rzecz społeczeństwa" (art. 4 ZРWКСв). Inny przykład takiego niedookreślonego wyrażenia to ,systematyczne nauczanie religii” (kan. 89 \ I PWKP).

Kilka wyrażeń niedookreślonych zastosowano w kan. $32 \$ 3$ Prawa Wewnętrznego Kościoła Polskokatolickiego w Rzeczypospolitej Polskiej. Przy określaniu warunków moralnych alumnów napisano, że musi ich cechować: „szczera pobożność”, „czysta intencja”, „umiłowanie Kościoła”.

I3 Por. Z. Ziembiński, Logika praktyczna, Warszawa 200I, s. 26.

I4 Zob. Z. Ziembiński, Logika praktyczna, dz. cyt., s. 29-30.

I5 Por. M. Zieliński, Wyktadnia prawa. Zasady..., dz. cyt., s. I65.

I6 Zob. szeroko o tym P. Kroczek, Niedookreśloność i nieostrość zwrotów w prawie kanonicznym na przyktadzie KPK z 1983 r., „Annales Canonici” I (2005), s. I75-185. 


\subsubsection{Zwroty nieostre}

Zwrot nieostry to taki, o którym pomimo zapoznania się z cechami danych przedmiotów nie potrafimy powiedzieć, czy jest desygnatem określonej nazwy, czyli nie jest pewne, czy wchodzi do jej zakresu czy też nie. Zakres tych zwrotów na gruncie danego języka nie jest ściśle ustalony ${ }^{17}$. Nieostrość jest kategorią logiczną.

Znamienną cechą nazw nieostrych jest to, że przedmioty, o których się orzeka, można podzielić na trzy grupy. Pierwsza grupa to ta, o której da się orzec bez wątpliwości, że są desygnatami określonej nazwy. Druga grupa przedmiotów z pewnością nie zawiera desygnatów tej nazwy. Trzecia grupa to przedmioty, co do których istnieje istotna wątpliwość, wahanie, czy są desygnatami tej nazwy czy też nie. Jest to skutkiem tego, że nazwy nieostre posiadają tzw. „pas nieostrości” lub „dwa pasy nieostrości” (w przypadku górnej i dolnej granicy określonej nazwy), w którym (lub w których) zawarte są przedmioty, o których trudno daną nazwę orzec ${ }^{18}$.

Przykładem zwrotu nieostrego jest wyrażenie nocturno tempore („pora nocna”) (kan. $938 \$ 4$ KPK). „Pora nocna” nie jest dokładnie określona, nie wiadomo, w jakich godzinach się zamyka. Oczywiście zwrot można wyostrzyć poprzez poznanie realiów danej parafii i ustalenie godziny „mszy świętej wieczornej” i „mszy świętej porannej”. Pora nocna powinna mieścić się pomiędzy tymi wydarzeniami. Należy jednak zwrócić uwagę na to, że określenia godziny mszy nie mają zawsze charakteru dowolnego. Niekiedy prawo zakreśla granice dla decyzji podmiotu władzy administracyjnej parafii, czyli co do zasady - proboszcza parafii. Jeżeli chodzi o mszę świętą wieczorną, to papież Pius XII w konstytucji apostolskiej Christus Dominus z I953 r. ${ }^{19}$ określit, że „msza święta wieczorna” nie może rozpoczynać się przed godziną $16.00^{20}$. Ta właśnie godzina, zgodnie z regulacjami Kościoła, rozpoczyna wieczór, a kończy „popołudnie” (post meridiem). Tak więc „wieczór” to czas po godzinie I6.oo do początku nowego dnia ${ }^{21}$.

I7 Por. M. Zieliński, Wyktadnia prawa. Zasady..., dz. cyt., s. I6I.

I8 Por. M. Zieliński, Wyktadnia prawa. Zasady..., dz. cyt., s. I65n.

I9 Pius pp. XII, Constitutio apostolica Christus Dominus de disciplina servanda quoad ieiunium Eucharisticum, 6.0I.1953, AAS 45 (1953), s. I5-24.

20 Pius pp. XII, Constitutio apostolica Christus Dominus, dz. cyt., nr 6.

2I Por. na ten temat: J. Hules, T. Willis, What Time for Anticipated Masses?, „Emmanuel” 96 (I990), s. 3I-4I. 
Innym przykładem zwrotu nieostrego jest „najbliższa rodzina” (art. 84 ust. I PWKE-M) czy „wolność od ciężkich ułomności cielesnych” (kan. 32 $\$$ I pkt b PWKP). Do nieostrych zwrotów można także zaliczyć termin „paramenty kościelne" (kan. I45 $\$ 6$ PWKP).

Zarówno nazwy niedookreślone, jak i nieostre ujmowane w aspekcie ich właściwości kwalifikowania można określić jako „nazwy szacunkowe”. Jednakże używanie w odniesieniu do nazw niedookreślonych lub nieostrych tego określenia jest możliwe tylko przy przyjęciu bardzo szerokiego rozumienia „szacowania”, a mianowicie takiego, które uwzględnia również kwalifikowanie w sposób prosty (ewidentny), czyli słownikowy lub legalny ${ }^{22}$. Dlatego lepiej wyróżnić dodatkowo zwroty szacunkowe i zwroty ocenne.

\subsubsection{Zwroty szacunkowe}

Zwroty szacunkowe to takie, których znaczenie można poznać wyłącznie poprzez kwalifikowanie, czyli szacowanie. Szacowanie polega na określeniu w przybliżeniu wielkości, stopnia natężenia, ilości oraz wartości materialnej czegoś $^{23}$. Chodzi więc o ustalenie faktów dopełniających treść całego zwrotu. Nie ma w tym przypadku kierunkowego odesłania, jakie jest przy klauzulach generalnych. Cechą zwrotów szacunkowych jest bowiem brak kryteriów, przez pryzmat których należy zwrot interpretować i rozstrzygać stany faktyczne ${ }^{24}$.

Ilustracją zwrotu szacunkowego mogą być wyrażenia z kan. 249 kodeksu prawa kanonicznego, w którym ustawodawca wzywa, aby alumni nie tylko nauczyli się accurate („dokładnie”) języka ojczystego, lecz także by bene („dobrze”) znali język łaciński oraz posiadali congruam („wystarczającą”) znajomość języków obcych. I choć można ustalić pewną hierarchię preferencji ustawodawcy, to znaczy, iż najlepiej powinien być alumnom znany język ojczysty, potem łaciński, a języki obce na końcu, to niemożliwe jest ustalenie na podstawie tego kanonu, o jaki stopień znajomości języków chodzi.

22 Por. A. Choduń, A. Gomułowicz, A. Skoczylas, Klauzule generalne i zwroty niedookreślone w prawie podatkowym i administracyjnym..., dz. cyt., s. 23; M. Zieliński, Wyktadnia prawa. Zasady..., dz. cyt., s. I72-173.

23 Por. A. Choduń, A. Gomułowicz, A. Skoczylas, Klauzule generalne i zwroty niedookreślone w prawie podatkowym i administracyjnym..., dz. cyt., s. 22.

24 Por. L. Leszczyński, Zagadnienia teorii stosowania prawa doktryna i tezy orzecznictwa, Kraków 2004, s. 44. 
Analogiczny szacunkowy charakter ma przepis ze statutu Karaimskiego Związku Religijnego wymagający, aby kandydat na stanowisko hachana był „biegłym w Piśmie Świętym i przepisach religijnych wyznania karaimskiego” ( $\$ 22$ ust. 2 lit. b). Taki sam zwrot zastosowano przy określaniu wymogów dla kandydatów na hazzana ( $\$ 32$ ust. 2 lit. a).

Podobne zwroty szacunkowe zawiera Zasadnicze Prawo Wewnętrzne baptystów. W art. 47 ust. 2 jest mowa o „rękojmi prawidłowego wykonywania zadań duszpasterskich i misyjnych” oraz o posiadaniu „dogłębnej znajomości Pisma Świętego".

Innym przykładem takiego szacunkowego zwrotu może być wyrażenie „ze względów szczególnych" z art. 24 statutu Kościoła Mariawitów pozwalające Prezydium Kapituły zmienić długość kadencji Kustosza albo Kustoszki. Zgodnie $\mathrm{z}$ zasadą ta kadencja trwa do 70. roku życia.

Także Pragmatyka Służbowa Kościoła Ewangelicko-Augsburskiego zawiera omawiane zwroty. Dla przykładu można podać przepis nakazujący duchowne$\mathrm{mu}$,usilnie pracować nad religijnym i wyznaniowym wychowaniem własnych dzieci” ( $\$$ I5I ust. 4 PSKE-A).

Zwrot szacunkowy „godni zaszczytu i przygotowani do pełnienia obowiązków” zawarty w przepisie kan. $92 \$ 3$ o brzmieniu „Pomocniczą służbę kościelną mogą sprawować wierni obojga płci godni tego zaszczytu i przygotowani do pełnienia powierzonych im obowiązków” należy odczytywać jako wskazówkę dla proboszcza Kościoła polskokatolickiego, który zatrudnia te osoby (kan. $92 \$ 2$ PWKP).

\subsubsection{Zwroty ocenne}

Zwroty ocenne (oceniające) związane są z oceną, a więc $\mathrm{z}$ aprobatą danego stanu albo dezaprobatą w odniesieniu do niego - coś jest dobre albo złe ${ }^{25}$. Wyrażają one stosunek kogoś do czegoś. W zasadniczym tekście polskich aktów normatywnych takich zwrotów „w ogóle nie ma” ${ }^{26}$. Występują one czasem w preambułach do aktów normatywnych ${ }^{27}$.

25 Por. M. Zieliński, Z. Ziembiński, Uzasadnianie twierdzeń, ocen i norm w prawoznawstwie, Warszawa 1988, s. 47.

26 Por. M. Zieliński, Wyktadnia prawa. Zasady..., dz. cyt., s. I73.

27 Dla przykładu można podać preambułę do Ustawy z dnia 26 stycznia 1982 r. Karta Nauczyciela (tekst jedn. Dz.U. z 2016 r. poz. I379 z późn. zm.): „Mając 
W prawie związów wyznaniowych zwroty ocenne są stosowane. W kan. II55 KPK ustalono, że „Współmałżonek niewinny może, w sposób godny pochwały, dopuścić z powrotem drugą stronę do życia małżeńskiego" ${ }^{28}$. Prawodawca wyraźnie pochwala taką decyzję niewinnego współmałżonka, choć jej nie nakazuje.

Widoczna tu odmienność prawa religijnego od prawa polskiego wynika $\mathrm{z}$ tego, że zasada ius non docet, sed iubet („prawo nie uczy, lecz rozkazuje”) względnie inna, lecz zawierająca podobny nakaz lex moneat, non doceat ${ }^{29}$ (,niech prawo napomina, a nie uczy"), nie musi być w kościele czy innym związku wyznaniowym w sposób absolutny przestrzegana. Prawodawca jest często także nauczycielem wiary dla wspólnoty religijnej ${ }^{30}$. Wykaz podmiotów posiadających kompetencje do stanowienia prawa dla kościołów i innych związków wyznaniowych umieszczony w II rozdziale tej książki w zasadzie pokrywa się z podmiotami pełniącymi funkcję nauczania treści wiary i podejmującymi decyzje w sprawach doktrynalno-moralnych.

\subsubsection{Odesłania do prawa związków wyznaniowych lub prawa państwowego}

Za klauzule generalne nie można uznać przepisów odsyłających do prawa związków wyznaniowych lub prawa państwowego. Przepisy te bowiem odsyłają zwykle do konkretnych aktów normatywnych lub gałęzi prawa. Także odesłania kompleksowe, czyli odesłania do systemu prawa nie należą do klauzul generalnych. Przykładem takich odesłań są zwroty: serventur praescripta iuris civilis

na względzie doniosłą rolę oświaty i wychowania w Rzeczypospolitej Polskiej, pragnąc dać wyraz szczególnej randze społecznej zawodu nauczyciela zgodnie z potrzebami i oczekiwaniami, otwierając niniejszą ustawą drogę do dalszych uregulowań prawnych systemu edukacji narodowej, stanowi się, co następuje”, czy też jeszcze wyraźniejszy przykład - Rozporządzenie Rady Ministrów z dnia 30 grudnia I98I r. w sprawie szczególnych przywilejów dla pracowników górnictwa - Karta górnika (Dz.U. z I982 r. Nr 2, poz. I3): „Wyrażając szczególne uznanie dla trudu górniczej pracy [...]”.

28 Can. II55: „Coniux innocens laudabiliter alterum coniugem ad vitam coniugalem rursus admittere potest, quo in casu iuri separationis renuntiat”.

29 Zob. Seneca ad Lucilium Epistulae Morales: with an English translation by Richard M. Gummere, transl. R. M. Gummere, London-New York 1925, Epistolae 94, 38: „Legem enim brevem esse oportet, quo facilius ab inperitis teneatur. Velut emissa divinitus vox sit: iubeat, non disputet".

30 W odniesieniu do Kościoła katolickiego zob. P. Kroczek, The Art of Legislation..., dz. cyt., s. I22. 
(„należy zachować przepisy prawa cywilnego”) (kan. $98 \$ 2 \mathrm{KPK}$ ), czy też zwrot „Kościół stosuje się do obowiązujących w Rzeczypospolitej Polskiej przepisów prawnych [...]” (art. 2 ust. 6 PWKE-M), jak również: „Sprawy majątkowe [...] reguluje Ustawa, a także przepisy prawa powszechnie obowiązującego" (art. 48 ust. 2 Pwwwż).

Zagadnienie odesłań do prawa egzogenicznego wobec związów wyznaniowych, czyli najczęściej do prawa państwowego, zostało już omówione i zegzemplifikowane w I rozdziale książki.

Wśród przepisów odsyłających znajdują się przepisy blankietowe. Nie wszystkie przepisy odsyłające są przepisami blankietowymi. Przepisy blankietowe to takie, które „zapowiadają unormowanie pewnej dziedziny spraw w określonej formie [...], a także przepisy odsyłające bez ograniczeń czy przepisy odsyłające «odpowiednio» do przepisów wydanych uprzednio dla innej dziedziny spraw" ${ }^{11}$. Nie należą więc do przepisów blankietowych przepisy odsyłające do konkretnych aktów prawnych, tu bowiem nie ma blankietu do wypełnienia. Jest tylko konkretny tekst normatywny i jego normatywna treść do zastosowania.

\subsubsection{Odesłania do sformalizowanych systemów pozaprawnych}

Odesłania do jasno określonych i sformalizowanych systemów pozaprawnych, obowiązujących podmioty, także nie są klauzulami generalnymi. Są to przykładowo odesłania do różnych dokumentów, którymi posługuje się kościół lub inny związek wyznaniowy. Przykładowo, w kontekście prawa Kościoła Ewangelicko-Metodystycznego chodzi o odesłania do: Zasad socjalnych, Społecznego Wyznania Wiary oraz Zasad ogólnych (Preambuła, PWKE-M). Wprawdzie przypisy te odsyłają poza system prawny - co jest cechą charakterystyczną klauzul generalnych - ale odnoszą się do określonego i sformalizowanego zbioru norm o charakterze aksjologicznym wyznaczających określone postępowanie podmiotów, a więc obowiązujących te podmioty ${ }^{32}$. Jest to odesłanie do systemu o charakterze wprawdzie nieprawnym, lecz jednak formalno-normatywnym,

3I S. Wronkowska, Z. Ziembiński, Zarys teorii prawa, dz. cyt., s. I54.

32 Por. A. Choduń, A. Gomułowicz, A. Skoczylas, Klauzule generalne i zwroty niedookreślone w prawie podatkowym i administracyjnym..., dz. cyt., s. 27. 
a więc wiążącym właściwie analogicznie jak system prawny. Niekiedy system, do którego przepisy te odsyłają, jest jakby skodyfikowany. Tak jest w przypadku Katechizmu Kościota Katolickiego, którego sama struktura przypomina kodeks. Trzeba zatem podkreślić, że nie są klauzulami generalnymi precyzyjne odesłania do poszczególnych części sformalizowanych źródeł norm pozaprawnych, takich jak katechizm.

Natomiast odesłania do jedynie ogólnie określonego zbioru norm, takiego jak normae vitae christianae („zasady życia chrześcijańskiego”) (kan. 767 $\$$ І крк), principia doctrinae catholicae („zasady doktryny katolickiej”) (kan. 8IO $\$ 2 \mathrm{KPK}$ ), „zasady wyznania ewangelicko-reformowanego” (art. II, art. 35 ust. I, art. 36 PWKE-R) czy też „zasady religijne i moralne judaizmu” (art. 9 pkt I PWwwż) są klauzulami generalnymi.

\subsubsection{Problem zwyczajów we wspólnotach religijnych}

Jeżeli przyjąć, że „zwyczaj”, rozumiany szeroko, to przyjęty w społeczności sposób postępowania w danej sprawie, zaś „obyczaj” to sposób postępowania należący do wą̧ko rozumianej sfery obyczajowości czy kultury obyczajowej, etosu ${ }^{33}$, to odesłania do „zwyczajów” lub „obyczajów” należy w kontekście prawa związków wyznaniowych uznać za klauzule generalne ${ }^{34}$.

Zasadniczo „zwyczaj” lub „obyczaj” to pewien pozaprawny zbiór reguł postępowania. Jest on niedookreślony zarówno pod względem zakresu, jak i pod względem treści. Adresaci, co do zasady, nie mają formalnego obowiązku przestrzegać zwyczajów czy obyczajów. Jednakże odesłanie w postaci klauzuli generalnej i tym samym nakaz prawodawcy dotyczący konkretyzacji zwyczaju lub obyczaju w procesie stosowania prawa powoduje, że zwyczaj lub obyczaj staje się źródłem norm.

Co innego, jeżeli utrwalone w społeczności postępowanie, czy to w postaci „zwyczaju”, czy „obyczaju”, zostało zawarte w akcie normatywnym bądź systemie redakcyjnie sformalizowanym i utrwalonym w postaci spisanego zbioru zasad

33 Por. R. Piszko, Odestania, klauzule generalne, luzy decyzyjne, „Ruch Prawniczy, Ekonomiczny i Socjologiczny” 63 (200I) z. I-2, s. 228. Niekiedy wyrażenia te stosuje się synonimicznie.

34 Inaczej, lecz w kontekście prawa polskiego, widzi tę sprawę Choduń w: A. Choduń, A. Gomułowicz, A. Skoczylas, Klauzule generalne i zwroty niedookreślone w prawie podatkowym i administracyjnym..., dz. cyt., s. 27. 
postępowania. Wówczas odesłanie do takiego „zwyczaju” czy „obyczaju” nie może być taktowane jak klauzula generalna.

Należy zaznaczyć, że w porządku prawnym Kościoła katolickiego „zwyczaj” (consuetudo) w rozumieniu „zwyczaju prawnego” (legitima consuetudo) jest równorzędnym wobec prawa stanowionego źródłem prawa - „Consuetudo autem est ius quoddam moribus institutum" ${ }^{35}$. Tak więc może on rodzić określone prawem konsekwencje normotwórcze. Droga do takiego waloru zwyczaju jest prawnie uregulowana: „Tylko ten zwyczaj wprowadzony przez wspólnotę wiernych posiada moc prawa, który został zatwierdzony przez prawodawcę, zgodnie z kanonami niżej zamieszczonymi" ${ }^{36}$ (kan. $23 \mathrm{KPK}$ ). Te warunki określają kan. 24-26 i kan. 28 kodeksu z 1983 r.

Istniejące obiektywnie i utrwalone jednością postępowanie większości członków wspólnoty wiernych w danej sprawie ${ }^{37}$ występującej dłuższy czas nazywane „zwyczajem faktycznym” lub „obyczajem” (mos), po spełnieniu określonych w wymienionych wyżej kanonach przesłanek staje się źródłem kanonicznych norm. Wówczas taki zwyczaj bywa określany w doktrynie kanonistycznej nadal jako „zwyczaj” (consuetudo) bądź jako „zwyczaj prawny” (legitima consuetudo) lub także jako „zwyczaj kościelny”, i staje się synonimem terminu „prawo zwyczajowe" ${ }^{38}$.

Nie wiadomo więc, czy klauzulą generalną będzie sformułowanie z kan. 1072 kodeksu prawa kanonicznego, w którym nakazuje się, aby duszpasterze odwodzili od „zawierania małżeństwa młodzież przed osiągnięciem wieku, w którym zgodnie z miejscowymi zwyczajami zawiera się małżeństwo” (,iuvenes ante aetatem, qua secundum regionis receptos mores matrimonium iniri solet") zależy to bowiem od tego, czy te zwyczaje wypełniają regulacje pochodzące z kanonów, które kwalifikują owe zwyczaje jako zwyczaje prawne. Podobna niepewność jest w przypadku sformułowań kodeksowych, takich jak: loci vel

35 Decretum magistri Gratiani, dz. cyt., D.I, C.V: „Zwyczajem jest zatem prawo wprowadzone przez obyczaje” (przeł. P. Kroczek).

36 Can. 23: „Ea tantum consuetudo a communitate fidelium introducta vim legis habet, quae a legislatore approbata fuerit, ad normam canonum qui sequuntur".

37 Por. F. Bączkowicz, Prawo kanoniczne. Podręcznik dla duchowieństwa, t. 2, przygotowali do druku i uzupełnili J. Baron i W. Stawinoga, Opole 19583, s. 217; por. Decretum magistri Gratiani, dz. cyt., D.I, C.V: „Mos autem est longa consuetudo, de moribus tracta tantumdem” („Obyczajem jest długi zwyczaj wypełniany przez stałe obyczaje") (przeł. P. Kroczek).

38 Por. F. Bączkowicz, Prawo kanoniczne. Podręcznik dla duchowieństwa, dz. cyt., s. 218 . 
regionis morem („zwyczaj miejsca lub regionu”) (kan. I304 $₫$ I KPK), usum et consuetudinem („obyczaj i zwyczaj”) (kan. $257 \$ 2$ KPK).

Natomiast nie jest klauzulą generalną odwołanie się w kodeksie prawa kanonicznego do kan. $527 \$$ I, gdzie wprost stanowi się o legitima consuetudine („prawnym zwyczaju”) czy probato Ecclesiae more („uznanym zwyczaju Kościota”) (kan. $945 \$$ I KPK), a także tradito Ecclesiae more (,ustalonym zwyczaju Kościoła”) (kan. I236 \ I KPK).

Podsumowując, można powiedzieć, że stosowanie klauzul generalnych nie wiąże się ani z doprecyzowaniem pasa nieostrości, ani z kwalifikowaniem wielkości, lecz z konfrontacją z aksjologicznym systemem pozaprawnym, którego istnienie czy treść są po pierwsze założone przez prawodawcę, a po drugie niezależne od dokonującego wykładni czy adresata norm ${ }^{39}$. Oczywiście trudno całkowicie zanegować subiektywne przekonania dokonującego wykładni przepisu zawierającego klauzulę generalną odnośnie do treści klauzuli generalnej.

\subsection{Cechy klauzul generalnych}

Można wyróżnić kilka cech konstytutywnych klauzul generalnych. Dla niniejszych rozważań będą istotne trzy cechy: niedookreśloność, pozaprawne odesłanie i aksjologiczność.

\subsubsection{Niedookreśloność}

Po pierwsze, klauzule generalnie cechuje niedookreśloność. Niedookreśloność zwrotu to inaczej jego niediagnostyczność. „Polega ona na tym, że zakres zwrotów będących klauzulami generalnymi nie jest ściśle określony ani niejednoznaczny. W konsekwencji brak jest czytelnej granicy pozwalającej rozstrzygnąć, co należy do desygnatów danego pojęcia, a co wychodzi poza ich zakres in concreto" ${ }^{\circ}$.

39 Por. A. Choduń, A. Gomułowicz, A. Skoczylas, Klauzule generalne i zwroty niedookreślone w prawie podatkowym i administracyjnym..., dz. cyt., s. 26.

40 A. Piaskowy, Klauzule generalne w projekcie nowego kodeksu cywilnego, „Transformacje Prawa Prywatnego" 3 (2012), s. 5o. 


\subsection{Cechy klauzul generalnych}

\subsubsection{Pozaprawne odesłanie}

Drugą cechą klauzul generalnych jest to, że przepisy je zawierające odsyłają do pozaprawnego zbioru aksjologicznego. Tę cechę podkreśla doktryna ${ }^{41}$. Taki też pogląd panuje w orzecznictwie ${ }^{42}$.

Desygnat klauzuli generalnej, czyli jej znaczenie, znajduje się poza tekstem prawnym i, co do zasady, poza systemem prawnym. Odesłanie może być skierowane do norm moralnych czy etycznych, poczucia sprawiedliwości, ocen i wartości funkcjonujących w danej grupie społecznej. Trzeba dodać, że to odesłanie ma postać kierunkową i systemową. Postać kierunkowa oznacza, że leksykalnie podana zostaje nazwa kryterium pozaprawnego. Ustawodawca wymienia konkretne wartości czy normy, jakie powinien zastosować stosujący prawo. Natomiast charakter systemowy wskazuje, że następuje odesłanie do systemu, konglomeratu ocen czy norm, a nie do jednostkowego szacowania ${ }^{43}$.

Istnieje opinia, lecz nie jest to powszechne stanowisko panujące w prawoznawstwie, że systemy norm moralnych nie istnieją, nie ma bowiem jakichś ustalonych czy powszechnie przyjętych reguł zachowania ${ }^{44}$. W konsekwencji uważa się, że przepisy zawierające klauzule generalne „nie są w istocie przepisami odsyłającymi, lecz nakazami oceniania i określania skutków prawnych, zgodnie z owymi ocenami, formułowanymi przez podmioty oceniające" 45 .

4I Zob. Z. Ziembiński, Problemy podstawowe prawoznawstwa, dz. cyt., s. 242; L. Leszczyński, Pojęcie klauzuli generalnej, „Annales Universitatis Mariae Curie-Skłodowska" 38 (1991), s. I63n; A. Choduń, A. Gomułowicz, A. Skoczylas, Klauzule generalne i zwroty niedookreślone w prawie podatkowym i administracyjnym..., dz. cyt., s. 30. Istnieją opinie negujące odesłanie, jako cechę klauzul generalnych. Wówczas klauzule generalne są rozumiane jako „oceny” lub „normy”. Zob. M. Pawełczyk, Uwagi o odsytającym charakterze klauzul generalnych, „Studia Iuridica Silesiana” 9 (I984), s. 94-95.

42 Zob. np. Wyrok Naczelnego Sądu Administracyjnego z dnia i6 stycznia 2002 r., III SA 2302/oo, Legalis nr 52899; Wyrok Trybunału Konstytucyjnego z dnia 7 grudnia 1999 r., к 6/99, Legalis nr 45625; Wyrok Sądu Najwyższego - Izba Pracy, Ubezpieczeń Społecznych i Spraw Publicznych z dnia 3 marca 2005 r., I PK 263/04, Legalis nr 70094; Postanowienie Naczelnego Sądu Administracyjnego z dnia 4 lipca 2012 r., II FZ 456/I2, Legalis nr 512435; Postanowienie Wojewódzkiego Sądu Administracyjnego z siedzibą w Poznaniu z dnia 28 października 20I3 r., I SA/Po 755/13, Legalis nr 984043 .

43 Por. G. Maroń, Zasady prawa. Pojmowanie i typologie a rola w wyktadni prawa i orzecznictwie konstytucyjnym, Poznań 20II, s. 9I.

44 Por. A. Piaskowy, Klauzule generalne w projekcie..., dz. cyt., s. 5I-52.

45 J. Nowacki, O przepisach zawierajacych klauzule generalne, [w:] Studia z teorii prawa, Zakamycze 2003, s. I33n. 
Takie ujęcie klauzul generalnych jest w kontekście przedmiotowych zwrotów w prawie kościołów i innych związków wyznaniowych nie do przyjęcia. Każdy bowiem związek wyznaniowy ma ustalony system dogmatyczno-moralny. Stanowi on zbiór zachowań modelowych dla członków danej wspólnoty religijnej. Bez tego zbioru nie byłoby żadnej różnicy pomiędzy tymi związkami, a być może nawet nie byłoby związku wyznaniowego jako takiego. Istotą religii jest przecież relacja człowieka do bóstwa, która przejawia się w treściach wyznawanej wiary ( $\mathrm{w}$ prawdach wiary) i w określonym tymi treściami zachowaniu wiernego. Obecność zasad moralnych w doktrynie kościołów lub innych związków wyznaniowych zakłada art. 85 ust. 3 Konstytucji RP 1997 r., w którym postanowiono, że „Obywatel, któremu przekonania religijne lub wyznawane zasady moralne nie pozwalają na odbywanie służby wojskowej, może być obowiązany do służby zastępczej na zasadach określonych w ustawie”. Tak samo stanowi się w art. 3 ust. 3 ustawy o gwarancjach wolności sumienia i wyznania.

Wydaje się, że przytoczony powyżej pogląd jest błędny także na gruncie systemu prawa polskiego. To prawda, że sądy nie badają opinii społecznej, aby ustalić, jakie przekonania żywi społeczeństwo i jakie wartości są powszechnie akceptowane ${ }^{46}$. Jednakże ustawodawca zakłada istnienie jakiegoś zbioru zasad moralnych. Przykładowo w art. 9 ust. I pkt 2 Ustawy z dnia 26 stycznia I982 r. Karta Nauczyciela ${ }^{47}$ stanowi, że stanowisko nauczyciela może zajmować osoba, która przestrzega „podstawowych zasad moralnych”. Podobnie w Ustawie z dnia 9 kwietnia 20 Io r. o Służbie Więziennej ${ }^{48}$ w art. 33 ust. I pkt I dotyczącym zasad etyki zawodowej ustawodawca nakazuje, aby Dyrektor Generalny określił w drodze regulaminu zasady etyki zawodowej, z uwzględnieniem „ogólnych wartości i norm moralnych”.

\subsubsection{Aksjologiczność}

Kolejną, trzecią, cechą klauzul generalnych jest ich wymiar aksjologiczny. Nieuznanie tej cechy klauzul mogłoby się wiązać z rozmyciem tych nazw w zbiorze wszelkich pojęć niedookreślonych. Byłoby to sprzeczne z istotą klauzul

46 Por. A. Piaskowy, Klauzule generalne w projekcie..., dz. cyt., s. 52.

47 Tekst jedn. Dz.U. z 2016 r. poz. 1379 z późn. zm.

48 Tekst jedn. Dz.U. z 2016 r. poz. 713 z późn. zm. 
generalnych, czyli legalnym nakazem uwzględnienia pozaprawnego zbioru wartości akceptowanego społecznie lub nakazanego w religijnej wspólnocie. Aksjologiczne wartości, do których klauzule generalne odsyłają dokonującego wykładni, nie muszą jednak być precyzyjnie ujęte. Niekiedy uważa się nawet, że ich zakres może być dookreślany intuicyjnie ${ }^{49}$.

W przypadku klauzul generalnych w prawie religijnym intuicyjne dookreślenie można powiązać z sensu fidelium („wyczuciem wierzących”), czyli wyczuleniem wierzących na sprawy ortodoksyjności wiary. Według nauki Kościoła katolickiego to wyczucie, oparte na asystencji Ducha Świętego, mają wszyscy wierni (zob. LG I2). Wierni jako wspólnota wiedzą, co jest w doktrynie ich religii akceptowane, a co nie, bez konieczności poznawania wcześniej nauczania Kościoła w konkretnej sprawie.

Dzięki wskazanym wyżej trzem cechom klauzule generalne mogą spełniać swoje funkcje.

\subsection{Funkcje klauzul generalnych}

Jurysprudencja wymienia kilka funkcji klauzul generalnych ${ }^{50}$. Występują one także w klauzulach generalnych w prawie związków wyznaniowych. Chodzi o takie funkcje, jak:

I. uzupełniająca,

2. korygująca,

3. interpretacyjna.

\subsubsection{Funkcja uzupełniająca}

Funkcja uzupełniająca klauzul generalnych służy dodaniu treści pozanormatywnej do norm zakodowanych bezpośrednio w przepisach, w zakresie, jaki nie został przez ustawodawcę doprecyzowany (zob. art. 56 k.c.). Chodzi więc o otwarcie treści normatywnej na wartości pozaprawne. Tym samym

49 Por. A. Malinowski, Redagowanie tekstu prawnego. Wybrane wskazania logiczno-jezykowe, Warszawa 2006, s. 37.

50 Por. A. Piaskowy, Klauzule generalne w projekcie..., dz. cyt., s. 58; L. Leszczyński, Tworzenie generalnych klauzul odsytających, dz. cyt., s. 163-176. 
społeczność staje się - poprzez życie społeczne - współtwórcą normy w jej bezpośrednim stosowaniu.

Nie jest to jednak prawotwórcza działalność czy to podmiotów stosujących prawo, czy to adresatów prawa ${ }^{\text {s1 }}$. Proces uzupełniania treści normy zakodowanej w przepisie dokonuje się zgodnie z wolą ustawodawcy, w zakresie przez niego przewidzianym - expressis verbis co do faktu, lecz blankietowo co do treści. Uzupełniona norma treściowo musi się mieścić w normie zawartej w przepisie ustanowionym. Jest ona tylko doprecyzowana w określonym kontekście. Jest to więc funkcja suplementarna, a nie konkurencyjna czy równoległa do funkcji, jaką wypełnia prawo stanowione.

Tę funkcję pełni klauzula generalna „dobre imię Kościoła” w zwrotach takich jak: „czyn godzący w dobre imię Kościoła” (\$2I ust. 3 ZPWKE-A), „dbanie o dobre imię Kościoła” (kan. 25 pkt a PWKP) „mieć na względzie dobre imię Kościoła” ( $\$ 243$ PSKE-A). Ta klauzula nakazuje interpretatorowi odwołać się do samorozumienia Kościoła i pojmowania dobra tej religijnej społeczności oraz do zasad nabywania, posiadania i utraty dobrego imienia powszechnie przyjętych w tejże społeczności, a także pośród osób nienależących do tego związku wyznaniowego. Tłumaczenie treści tej klauzuli generalnej jest również możliwe poprzez odwołanie się do prawa polskiego jako źródła pomocniczego (zob. art. 23 k.c. oraz 43 k.c.).

Inny przykład klauzuli pełniącej omawianą funkcję zawiera kan. $285 \$ 2$ kodeksu łacińskiego. W celu omówienia zostanie on zacytowany w całości, $\$$ I: „Duchowni powinni powstrzymać się od tego wszystkiego, co wprost nie przystoi ich stanowi, według przepisów prawa partykularnego" oraz $₫ 2$ : „Duchowni niech unikają tego, co chociaż nie jest nieprzyzwoite, jednak obce stanowi duchownemu" ${ }^{52}$. Klauzulą generalną jest zwrot a clericali statu aliena („obce stanowi duchownemu”). Aby poznać jego znaczenie, należy odwołać się do etosu duchownego w Kościele oraz uwzględnić opinie wiernych w tym zakresie. Nie jest natomiast klauzulą generalną wyrażenie quae statum suum dedecent, prorsus abstineant, iuxta iuris particularis praescripta (,co wprost nie przystoi ich stanowi, według przepisów prawa partykularnego"), albowiem jest to zwyczajne odesłanie do przepisów prawa i tego, co ustawodawca określił

5I Por. L. Leszczyński, Tworzenie generalnych klauzul odsytajacych, dz. cyt., s. I65.

52 Can. $285 \$$ I: „Clerici ab iis omnibus, quae statum suum dedecent, prorsus abstineant, iuxta iuris particularis praescripta. $\$ 2$. Ea quae, licet non indecora, a clericali tamen statu aliena sunt, clerici vitent". 
w nich jako „wprost nieprzystające do stanu”. Wskazane wyrażenie to zatem odesłanie wewnątrzsystemowe.

Przepis art. 76 Prawa Wewnętrznego ewangelików reformowanych o brzmieniu: „Duchowny, który wypacza zasady wyznania lub postępowaniem uwłacza godności swego powołania, może być skreślony z listy duchownych przez Synod na wniosek konsystorza" także zawiera klauzulę generalną odwołującą się do zasad tego wyznania i do godności duchownego, tak jak jest ona rozumiana przez to wyznanie. Z kolei w $\$ 44$ pkt 4 Statutu Muzułmańskiego Związku Religijnego z 2009 r. stanowi się, że imam lub muezin może być zawieszony w pełnieniu funkcji bądź zwolniony z jej pełnienia m.in. w przypadku popełnienia czynu „niezgodnego z etyką i zasadami religii muzułmańskiej”, "przestępstwa popełnionego z niskich pobudek”, jak też za „popełnienie czynu hańbiącego”. W statucie tego związku z 1936 r. w $\$ 34$ nr 3 użyto klauzuli „,czyn nie licujący z godnością duchownego" jako przyczyny ukarania imama lub muezina przez muftiego.

Uzupełniającą funkcję ma klauzula generalna w przepisie art. 90 PWKE-M: „Członek parafii podlega odpowiedzialności dyscyplinarnej za wykroczenie przeciwko zasadom moralności chrześcijańskiej i obowiązkom wyznawcy Kościoła Ewangelicko-Metodystycznego” oraz w art. 93: „Duchowny Kościoła podlega odpowiedzialności dyscyplinarnej za naruszenie obowiązków lub uchybienie godności duchownego oraz za wykroczenie przeciwko zasadom moralności chrześcijańskiej”. Klauzulami generalnymi są tu: „zasady moralności chrześcijańskiej” oraz „godność duchownego”.

Przy ustalaniu znaczenia klauzul generalnych z Prawa Wewnętrznego Kościoła Polskokatolickiego w Rzeczypospolitej Polskiej, takich jak: „uczciwe i nienaganne pod względem moralnym życie” (kan. $32 \$ 3$ pkt d PWKP), „przykład pobożności i cnót moralnych” (z kan. 35 pkt a PWKP) czy „przykład i wzór cnót chrześcijańskich” (kan. $37 \$ 2$ PWKP), „przykładne życie religijne i moralne” (kan. $50 \$ 3$ pkt b PWKP), „chrześcijański sposób życia” (kan. $50 \$ 3$ pkt b PWKP), należy oczywiście odnieść się do zasad moralnych i pobożnościowych tego Kościoła. Tak samo trzeba zakwalifikować wyrażenia: „nieposzlakowana opinia” (art. I2 ust. I PWKE-M) Czy „nieposzlakowana opinia w społeczności” (kan. 9I \$4 pkt c PWKP), które odwołują się do zasad moralnych i etycznych tego Kościoła.

Zapewne także klauzuli generalnej „duch braterstwa i wzajemnej pomocy” pochodzącej z Prawa Wewnętrznego Kościoła Ewangelicko-Reformowanego można przypisać uzupełniającą funkcję (art. 42 PWKE-R), choć na pierwszy rzut oka to wyrażenie wydaje się być zwrotem niedookreślonym. Jednym z istotnych 
elementów doktryny Kościoła, z którego prawa pochodzi ta nazwa, jest przecież miłość bliźniego, i to decyduje o tym, że jest to klauzula generalna.

W statucie Wschodniego Kościoła Staroobrzędowego także znajdują się klauzule generalne o funkcji uzupełniającej. Zawarta w $\$ 48$ tegoż aktu prawnego norma zezwala Naczelnej Radzie Staroobrzędowców zawiesić członka Rady Gminy w czynnościach urzędowych, w razie stwierdzenia „szkodliwej dla dobra Kościoła i Państwa lub karygodnej działalności”. Klauzulą jest wyrażenie „dobro Kościoła”, lecz nie jest nią zwrot „karygodna działalność”. To drugie wyrażenie odwołuje się prawdopodobnie nie tylko do wewnętrznego prawa karnego tego związku wyznaniowego, ale także - można tak założyć po uwzględnieniu form relacji tego Kościoła do państwa - prawa polskiego. Podobne odesłanie znajduje się w $\$ 5$ o lit. d tego statutu, w którym chodzi o osoby uznane „przez Sądy Powszechne za winne zbrodni lub czynów karygodnych z chęci zysku lub uwłaczających moralności”. O ile termin „zbrodnia” jest zdefiniowany w polskim kodeksie karnym (art. $7 \$ 2$ k.k.), o tyle „czyn karygodny z chęci zysku” już nie. Być może chodzi o przestępstwo skarbowe lub wykroczenie skarbowe, czy też o inny występek (art. $7 \$ 3$ k.k.) względnie wykroczenie (art. I $\$$ I k.w. ${ }^{53}$ ). Natomiast zwrot „uwłaczanie moralności” jest klauzulą generalną i nakazuje, jak się wydaje, odwołać się w pierwszej kolejności do zasad moralności głoszonych przez dany Kościół. Nie wyklucza to również uwzględnienia „moralności publicznej” (zob. art. 3 ust. I, art. 27 ust. I, art. 33 ust. 3 u.g.w.s.w.) czy też „moralności” (zob. art. 153 i art. 427 k.p.c.), tak jak te terminy rozumieją i stosują organy władzy publicznej.

Wydaje się, że klauzulą generalną jest zwrot „działanie sprzeczne z interesem RP” pochodzący z analizowanego powyżej statutu ( $\$ 5$ o lit. $\mathrm{f}$ swKs). Wyrażenie to odwołuje się nie do ocen i norm typowo kościelnych, lecz państwowych. Jednocześnie trzeba pamiętać, że istnieją przepisy karne definiujące negatywnie interes państwowy poprzez określenie przestępstw przeciwko państwu polskiemu i jego obronności (zob. I27-I47 k.k.). Gdyby uznać, że omawiany zwrot odnosi się do tych właśnie przepisów, nie można by go zaliczyć do zbioru klauzul generalnych.

Egzemplifikowaną funkcję pełnią ponadto klauzule zaprezentowane wcześniej licznie przy definicji tego zwrotu. Dotyczy to zasad związanych z nauczaniem konkretnego kościoła lub innego związku wyznaniowego:

53 Ustawa z dnia 20 maja I97I r. Kodeks wykroczeń (tekst jedn. Dz.U z 2015 r. poz. I094 z późn. zm.). 
principiorum doctrinae catholicae („zasad doktryny katolickiej”) (kan. 810 $\$ 2$ KPK), „Zasad religii muzułmańskiej” ( $\$ 46 \mathrm{nr} 3$ SMZR2009), „Zasad nauki islamu” ( $\$ 5 \mathrm{nr}$ I SMZRI936), „zasad religijnych i moralnych judaizmu” (art. 9 pkt 2 PWwż), ,zasad religii karaimskiej” (\$ 35 lit. b skzR), „zasad baptyzmu” (art. 4 ZPWкСнв), „Zasad wyznania ewangelicko-reformowanego” (art. II, art. 35 ust. I, art. 36 PWKE-R), a także ogólnych zasad religijnych, które jednak należy odczytywać w kontekście prawa konkretnego związku wyznaniowego: „W myśl zasad Kościoła” (art. 6 PWKE-R), normae vitae christianae (,zasad życia chrześcijańskiego") (kan. $767 \$$ I KPK), „Zasad religijnych i moralnych judaizmu” (art. 9 pkt I PWwwż), czy też „chrześcijańskiego sposobu życia” (kan. $50 \$ 2$ pkt b PWKP).

Oczywiście należy przyjąć, że podobne formalnie klauzule generalne odwołujące się do chrześcijaństwa, czyli przykładowo jego ogólnych zasad czy też praktyki życia, pochodzące z prawa Kościołów chrześcijańskich, będą miały podobne znacznie. Powodem jest ten sam rdzeń doktrynalny oparty na Piśmie Świętym i orzeczeniach pierwszych siedmiu soborów powszechnych.

\subsubsection{Funkcja korygująca}

Funkcja korygująca klauzul generalnych sprawia, że zwroty te działają, do pewnego stopnia, podobnie jak normy prawa stanowionego. Mogą one powodować nieskuteczność pewnych czynności podejmowanych na podstawie przepisów prawa i w ten sposób chronić przed nadużyciem prawa lub jego złym użyciem, czyli takim, które nie byłoby w sposób oczywisty zgodne z mente legislatoris. Ta funkcja to swoisty „zawór bezpieczeństwa” (zob. art. 5 k.c.) ${ }^{54}$. Trzeba dodać, że chodzi o korektę, a nie o fundamentalną zmianę treści normy, dokonaną pod wpływem zastosowania w wykładni klauzuli generalnejss. Gdyby bowiem jakaś norma w prawie religijnym była sprzeczna z zasadami doktrynalnymi

54 Zieliński przytacza odpowiedniki tego terminu w literaturze niemiecko- i anglojęzycznej, odpowiednio: Angstklausel i safety valve. Zob. T. Zieliński, Klauzule generalne w prawie pracy, dz. cyt., s. 32.

$55 \mathrm{~W}$ polskim orzecznictwie panował inny pogląd. Sąd Najwyższy w Wyroku z dnia I7 grudnia I984 r., IV PR 225/84, Legalis nr 24525, powołując się na art. 56 kodeksu cywilnego, dopuszczał możliwość modyfikacji umowy na podstawie zasad współżycia społecznego, jeśli tego wymaga nadzwyczajna sytuacja (kryzys społeczno-gospodarczy). 
głoszonymi przez związek wyznaniowy, to po prostu norma taka by nie obowiązywała i nie byłoby konieczności jej fundamentalnego modyfikowania.

Nie można więc uznać, że klauzule generalne to przepisy, na mocy których ustawodawca „otworzył prawo" i udzielił organom stosującym to prawo delegacji do podejmowania swobodnych decyzji o charakterze normotwórczym. Zastosowanie klauzul generalnych nie jest także zdaniem się prawodawcy na subiektywny system wartości dokonującego wykładni. Należy zwrócić uwagę, że we wszystkich badanych kościołach i innych związkach wyznaniowych organy władzy ustawodawczej są ściśle określone. Owszem, klauzule generalne pozwalają prawu endogenicznemu wspólnot religijnych na rozwój oraz na zmiany bez konieczności jego nowelizacji. Jest to cenne praktyczne rozwiązanie szczególnie dla małych wspólnot.

Na powyższym teoretyczno-prawnym tle można podać kilka przykładów klauzul wypełniających omawianą funkcję. Wydawać by się mogło, że wyrażenie iusta causa („słuszna przyczyna”) z prawa kanonicznego Kościoła katolickiego to zwrot szacunkowy. Można go prima facie powiązać z jednostkowym szacowaniem. Jednakże jest to klauzula generalna, która odsyła do pojęcia iustitia, czyli do sprawiedliwości, prawości i słuszności ${ }^{56}$, takiej jak ją rozumie się w tym Kościele, biorąc pod uwagę jego doktrynalno-moralne fundamenty. To, co jest sprawiedliwe, prawe, prawidłowe w ocenie dokonanej pod kątem wartości katolickich, będzie przysługiwało się dobru duchowemu wiernego. Widać to wyraźnie w kontekście instytucji prawnej dyspensy (zob. kan. 90 \$ I w związku z kan. $87 \$$ I i kan. 88 KPK ${ }^{57}$ ). Omawiana klauzula generalna pełni funkcję korygującą w kan. $1267 \$ 2$ kodeksu prawa kanonicznego. Kanon ten zabrania nieprzyjmowania ofiar na rzecz kościelnej osoby prawnej lub prywatnej, chyba że „iusta de causa et, in rebus maioris momenti, de licentia Ordinarii” („ze słusznej przyczyny i w sprawach większej wagi za zezwoleniem ordynariusza”). Oczywiście, zwrot rebus maioris („większej wagi”) jest typowym zwrotem szacunkowym. Nie ma bowiem zewnętrznych kryteriów pomocnych przy ustaleniu jego znaczenia.

56 Por. Iustitia, [w:] A. Jougan, Stownik kościelny tacińsko-polski, Poznań-Warszawa-Lublin I958, s. 37I.

57 U podstaw dyspensy stoi „dobro duchowe” i to dobro jest przyczyną, dla której udziela się dyspensy. Klasyczna definicja dyspensy brzmi: „Est itaque dispensatio iusta causa faciente ab eo, cuius interest, canonici rigoris casualis facta derogatio" (Rufino, Summa decretorum, ed. H. Singer, Paderborn 1902, ad C.I q.7 d. a. c.6, s. 234). 
W tym miejscu należy zaznaczyć, że w kodeksie prawa kanoniczego zwrot iusta causa występuje wiele razy i jest on różnorodnie tłumaczony: w kan. 56, kan. II43 $\$$ I jako „słuszny powód”, w kan. 72 jako „słuszna przyczyna”, w kan. $964 \$ 3$, kan. II46 pkt 2, kan. I342 \$ I jako „uzasadniona przyczyna”. Ponadto zwrot ten jest stosowany z pewnymi modyfikacjami, np.:

I. iusta et rationalibis causa - w kan. $90 \$$ I (,słuszna i racjonalna przyczyna”), kan. 83I \ I, kan. 906 („słuszna i uzasadniona przyczyna”), kan. II25 („słuszna i rozumna przyczyna”),

2. iusta et necessaria causa - w kan. I308 \$ I, kan. I310 $\$$ I („słuszna i konieczna przyczyna"),

3. iusta et proportionata causa - w kan. $189 \$ 2$ (,stuszna i proporcjonalna przyczyna”).

Przytoczone rozbieżności w tłumaczeniach polegające na oddawaniu tego samego zwrotu łacińskiego przy pomocy różnych polskich znaczeń pokazują, że nie można przyjmować za podstawę wyłącznie polskiej wersji tłumaczenia tej ustawy, lecz trzeba sięgać do tekstu oryginalnego ${ }^{58}$.

Z kolei kan. I93 $\$$ I z cytowanego wyżej kodeksu ma brzmienie: „Z urzędu nadanego komuś na czas nieokreślony nie można go usunąć, chyba że na skutek poważnych przyczyn oraz z zachowaniem sposobu postępowania określonego prawem” stanowiącą, że nie można usuwać z urzędu powierzonego. Nie jest to jednak klauzula generalna, lecz zwrot szacunkowy. Przy określaniu, czy przyczyna jest poważna, nie trzeba odwoływać się do konglomeratu ocen czy norm poza systemem, lecz wystarczy doprecyzować pas nieostrości. Dzięki nazwie nieostrej gravis prawodawca umożliwia pewne dostosowanie normy do aktualnego kontekstu, w którym norma ma być zastosowana. Tak samo jest w kan. 494 $\$ 2$, kan. $686 \$$ I i $\$ 3$, kan. $884 \$ 2$, kan. I5I4, kan. I529, kan. $1737 \$ 3$ (w tych kanonach tłumaczone jako „ważna przyczyna”) oraz w kan. $190 \$ 2$ 2, kan. 193 $\$$ I, kan. 270, kan. 290 pkt 3, kan. $320 \$$ I, kan. $40 \mathrm{OI} \$ 2$, kan. $667 \$ 4$, kan. 726 $\$ 2$, kan. $767 \$ 2$, kan. 860 \$ I, kan. 89I, kan. $938 \$ 4$, kan. $974 \$$ I, kan. I038, kan. IO77 \ I, kan. II44\$ 2, kan. II47, kan. II64, kan. I248 2 , kan. I33I 2

58 Indeks słów użytych w kodeksie zawiera X. Ochoa, Index verborum ac locutionum Codicis Iuris Canonici, Roma 1983.

59 Can. I93 $\$$ I: „Ab officio quod alicui confertur ad tempus indefinitum, non potest quis amoveri nisi ob graves causas atque servato procedendi modo iure definite". 
pkt I, kan. I36I $\$ 2$, kan. I487, kan. I532, kan. I603 \$2, kan. I736\$3 (w tych kanonach tłumaczone jako „poważna przyczyna”).

Korygującą funkcję pełni także zwrot szacunkowy „poważne trudności” z $\$$ I36 Pragmatyki Służbowej Kościoła luterańskiego. Podstawowa norma nakazuje zawarcie małżeństwa wiernemu wyznania ewangelicko-augsburskiego wobec duchownego tego Kościoła (\$ I35 PSKE-A). Jednakże, gdy zaistnieje przesłanka „poważnych trudności”, która „,nie pozwala zachować powyższego wymogu", należy postarać się o stosowną dyspensę ( $\$$ I36 PSKE-A). Identyczny zwrot zawiera art. 40 ust. I Zasadniczego Prawa Wewnętrznego baptystów. Nie są to klauzule generalne.

Innym tego typu zwrotem, który może być mylony z klauzulą generalną, jest zwrot „z ważnych przyczyn” występujący dwukrotnie w statucie obowiązującym adwentystów (art. 24 ust. 2 oraz art. 3I ust. I SKADs) lub w „szczególnie uzasadnionym przypadku" (I, 5 RSKZ $^{60}$ ).

Natomiast niektóre nazwy z kodeksu prawa kanonicznego z 1983 r. wprost odnoszą się do kanonicznych przyczyn. Można je więc uznać nie za klauzule generalne, lecz za zwroty odsyłające intepretującego do samego systemu prawnego, choć to odesłanie nie ma jasnego charakteru. Chodzi tu o zwroty, takie jak: I. causa canonica - kan. 1030 (,kanoniczna przyczyna”),

2. legitima causa - kan. II5I, kan. II53 \ I (,zgodna z prawem przyczyna”), 3. legitima gravique causa - kan. I422 („prawnie uznana i poważna przyczyna”), 4. causa iure proprio statuta - kan. $624 \$ 3$ („określona w prawie przyczyna”). Trzeba dodać, że niekiedy prawodawca stosuje liczbę mnogą w powyższych wyrażeniach - np. w kan. $193 \$$ I, kan. 270, kan. $320 \$ 2$, kan. $624 \$ 3$, kan. 689 \I, kan. 69I $\$$ I, kan. $696 \$$ I i $\$ 2$, kan. I095 nr 3, kan. I736\$2. Ma to jednak znaczenie wyłącznie przy rozważaniu konkretnego przypadku prawnego, a nie przy ogólnych rozważaniach.

Przedstawianą funkcję korygującą pełnią także zwroty kodeksowe, takie jak: ob speciales et graves omnino rationes (,ze względu na specjalne i wyjątkowo poważne racje”) (kan. 37I $\$ 2$ KРК), certis in casibus ob specialia (,ze względu na specjalne okoliczności”) (kan. $4 \mathrm{O} 2 \$$ I KPK), ob peculiaria adiuncta („ze względu na szczególne okoliczności”) (kan. $5 \mathrm{I} 6 \$$ I крк) - nie są to klauzule generalne, ale zwroty szacunkowe.

6o Regulamin Synodu Kościoła Zielonoświątkowego w RP z dnia 25.09.2015 r. (archiwum prywatne autora, sygn. $\mathrm{Kz} / 2$ ). 
Także nie są klauzulami generalnymi wyrażenia pochodzące z cytowanego kodeksu: intuitu boni communis (,ze względu na dobro wspólne”) (kan. 223\$2 KРК), propter Regnum coelorum (,ze względu na Królestwo niebieskie”) (kan. 277 $\$$ I КРК), czy intuitu utilitatis communis (,ze względu na wspólny pożytek”) (kan. 59I KPK). Wprawdzie mogło by się wydawać, że są to odesłania do systemu ocen funkcjonujących poza prawem, jednakże - jak wynika z redakcji tych zwrotów - wyznaczają one motywację do przestrzegania normy, do której są dołączone, czyli stanowią uzasadnienie dla jej istnienia i obowiązywania, lecz nie wypełniają tej normy treścią.

Wniosek, który z tego zestawienia się nasuwa, jest taki, że zdecydowanie najwięcej klauzul korygujących odsyła do słuszności, którą można rozumieć jako słuszność w prawie oraz słuszność moralną, etos chrześcijanina czy etos człowieka wierzącego.

\subsubsection{Funkcja interpretacyjna}

Funkcja interpretacyjna polega na tym, że użyta klauzula generalna nie służy do uzupełniania czy korygowania treści dokonanej czynności prawnej stosownie do jakichś kryteriów ocennych. Jej celem jest jedynie usuwanie niejasności i wątpliwości przy ustalaniu właściwego sensu przepisu (zob. art. 65 k.c.).

Opisywaną funkcję pełni klauzula z kan. 1343 łacińskiego kodeksu prawa kanonicznego: „Jeśli ustawa lub nakaz daje sędziemu władzę wymierzenia lub niewymierzenia kary, sędzia może także zgodnie ze swoim sumieniem i roztropnością złagodzić karę lub zamiast niej nałożyć pokutę" ${ }^{61}$. Klauzulą jest tu wyrażenie: pro sua conscientia et prudentia (,zgodnie ze swoim sumieniem i roztropnością"). Podobny przykład zawarty jest w kan. 43 cytowanego kodeksu: „Zgodnie ze swoim roztropnym uznaniem, wykonawca może wyznaczyć swego zastępcę [...]"62. Klauzula określa, w jaki sposób ma się dokonać ta czynność prawna: pro suo prudenti arbitrio (,zgodnie z roztropnym uznaniem”). Taką samą funkcję pełni ta klauzula generalna m.in. w kan. $468 \$$ I, kan. $553 \$ 2$ oraz kan. 1343 kodeksu. Klauzulę o takim samym niemal brzmieniu i identycznej

6I Can. 1343: „Si lex vel praeceptum iudici det potestatem applicandi vel non applicandi poenam, iudex potest etiam, pro sua conscientia et prudentia, poenam temperare vel in eius locum paenitentiam imponere".

62 Can. 43: „Actus administrativi exsecutor potest alium pro suo prudenti arbitrio sibi substituere [...]". 
funkcji zawiera Pragmatyka Służbowa Kościoła Ewangelicko-Augsburskiego, która pozostawia „woli i roztropności Biskupów naszego Kościoła i Biskupów bratnich Kościołów chrześcijańskich” sprawę ich udziału w święceniach duchownych (\$ I92 PSKE-A).

Wymienione wyżej zwroty odsyłają poza system prawny - do sumienia lub roztropności. Nie można uznać, że jest to odniesienie do zbiorów norm obiektywnie wyznaczających racjonalne postępowanie. Zarówno bowiem postępowanie zgodne z sumieniem, jak i roztropnością wiąże się z oceną postępowania według sytemu aksjologicznego obowiązującego w Kościele lub związku wyznaniowym. Ten fakt wskazuje, że zwroty te to klauzule generalne.

Natomiast zwrot „prawidłowe zabezpieczenie majątku” ( $\$ 8$ ust. 3 ZPWKE-A) nie jest klauzulą generalną. Można się bowiem domyślać, że tym prawidłem jest prawo wewnętrzne Kościoła, prawo polskie oraz powszechnie przyjęte zasady gospodarowania.

Z kolei luterańskie Zasadnicze Prawo Wewnętrzne w $₫ 8$ ust. I stanowi, że „Wszystkie jednostki organizacyjne Kościoła zobowiązane są do dbałości o racjonalne, ekonomiczne, uzasadnione oraz zgodne z etyką i powagą Kościoła wykorzystywanie majątku będącego w ich władaniu”. Możliwe jest wydzielenie z tego przepisu kilku zwrotów, które należałoby odpowiednio zakwalifikować. Zwroty „racjonalne wykorzystywanie majątku”, „ekonomiczne, uzasadnione wykorzystywanie majątku" nie są klauzulami generalnymi. Odwołują się do zbiorów norm niemających charakteru aksjologicznego. Natomiast zwrot „zgodne z etyką i powagą Kościoła wykorzystywanie majątku” zawiera odniesienie do religijnego i aksjologicznego źródła - jest to zatem klauzula generalna pełniąca funkcję uzupełniającą.

\subsubsection{Kontekst wyznaczający funkcję}

Niekiedy te same klauzule generalne mogą pełnić różne funkcje w zależności od kontekstu, w którym zostały użyte. To stwierdzenie należy poprzeć egzemplifikacjami.

Klauzulą generalną często stosowaną w łacińskim prawie kanonicznym jest wyrażenie spirituale bonum („dobro duchowe”). Pełni ono przynajmniej dwie funkcje: interpretacyjną i uzupełniającą. Kontekst umieszczenia tego zwrotu w kan. 87 \ I jest następujący: „Biskup diecezjalny może dyspensować wiernych - ilekroć uzna to za pożyteczne dla ich duchowego dobra - od ustaw 
dyscyplinarnych, tak powszechnych, jak i partykularnych, wydanych przez najwyższą władzę kościelną [...]”. W tym kontekście przedmiotowe wyrażenie pełni funkcję interpretacyjną. Do biskupa należy bowiem ocena pożyteczności jego administracyjnego działania dla dobra duchowego wiernych. To samo wyrażenie zostało umieszczone w kan. 6I4 kodeksu o brzmieniu: „Klasztory mniszek złączone z jakimś instytutem męskim, zachowują własny sposób życia i zarządzania, zgodnie z konstytucjami. Wzajemne prawa i obowiązki należy określić w ten sposób, żeby wspomniane złączenie mogło pomnożyć dobro duchowe”. W tym kontekście wyraźnie pełni ono funkcję uzupełniającą.

Wielość funkcji została przypisana przez kontekst do wyrażenia bonum animarum, czyli „dobra dusz” lub też w innym tłumaczeniu wziętym z kodeksu łacińskiego „dobra wiernych”. W kan. 364 ta klauzula pełni funkcję uzupełniającą: „Głównym zadaniem legata papieskiego jest [...] przesyłanie do Stolicy Apostolskiej wiadomości na temat warunków, w których znajdują się Kościoły partykularne, i o tym wszystkim, co dotyczy życia samego Kościoła i dobra dusz"63. Taką samą funkcję przedmiotowe wyrażenie pełni w kan. $1748^{64}$ i w kan. I215 $\mathrm{nr}^{6}{ }^{65}$. Natomiast w kan. I222 $\$ 2$ kodeksu wyrażenie to ma funkcję korygującą: „Gdy inne poważne racje doradzają wyłączenie jakiegoś kościoła ze sprawowania w nim kultu Bożego, biskup diecezjalny, wysłuchawszy zdania Rady kapłańskiej, może go przeznaczyć na cele świeckie, ale nie niewłaściwe,

63 Can. 364: „Praecipuum munus Legati pontifici est [...] ad Apostolicam Sedem notitias mittere de condicionibus in quibus versantur Ecclesiae particulares, deque omnibus quae ipsam vitam Ecclesiae et bonum animarum attingant".

64 Kan. I748: „Jeśli wymaga tego dobro dusz albo potrzeba lub pożytek Kościoła, by proboszcz ze swojej parafii, którą owocnie kierował, został przeniesiony do innej parafii albo na inny urząd, biskup powinien mu na piśmie zaproponować przeniesienie i zachęcić, aby się na nie zgodził, ze względu na miłość Boga i dusz”.

Can. 1748: „Si bonum animarum vel Ecclesiae necessitas aut utilitas postulet, ut parochus a sua, quam utiliter regit, ad aliam paroeciam aut ad aliud officium transferatur, Episcopus eidem translationem scripto proponat ac suadeat ut pro Dei atque animarum amore consentiat”.

65 Kan. I215 $\$ 2$ : „Biskup diecezjalny nie powinien udzielać zezwolenia, jeśli, po wysłuchaniu zdania Rady kapłańskiej i rektorów sąsiednich kościołów, nie uzna, że nowy kościół może służyć dobru wiernych i że nie zabraknie środków koniecznych na wybudowanie kościoła i sprawowanie kultu Bożego”.

Can. I2I5 $\$ 2$ : „Episcopus dioecesanus consensum ne praebeat nisi, audito consilio presbyterali et vicinarum ecclesiarum rectoribus, censeat novam ecclesiam bono animarum inservire posse, et media ad ecclesiae aedificationem et ad cultum divinum necessaria non esse defutura”. 
za zgodą tych, którzy w stosunku do tego kościoła nabyli słuszne uprawnienia, jeśli dobro dusz nie doznaje z tego żadnej szkody”" ${ }^{66}$.

Inny jeszcze problem zmiany funkcjonalnej kategorii klauzul można zaobserwować na przykładzie klauzuli „przykładne wypełnianie swoich dotychczasowych obowiązków” (kan. 67 PWKP). O zaliczeniu tej klauzuli do zbioru klauzul interpretujących decyduje to, że o tym, czy dana osoba realizuje określone zadania w sposób „przykładny”, decyduje ona sama lub podmiot upoważniony do dokonania takiej oceny. Ewaluacja tego zachowania i przyrównanie go do wzorca, czyli do „przykładu”, pozwala na ustalenie, czy norma z tego przepisu jest zrealizowana czy nie. Przy innym rozłożeniu akcentów, to znaczy przy zwróceniu większej uwagi na „przykład” jako wzór zachowania, klauzula ta mogłaby być także zaliczona do klauzul uzupełniających.

Wszystkie te funkcje pełnione przez klauzule generalne służą uelastycznieniu tekstu prawnego ${ }^{67}$. Nota bene taką też rolę wyznacza klauzulom generalnym prawodawca polski w $\$$ I55 ust. I załącznika do Rozporządzenia Prezesa Rady Ministrów z dnia 20 czerwca 2002 r. w sprawie „Zasad techniki prawodawczej”" ${ }^{8}$ : „Jeżeli zachodzi potrzeba zapewnienia elastyczności tekstu aktu normatywnego, można posłużyć się określeniami nieostrymi, klauzulami generalnymi albo wyznaczyć nieprzekraczalne dolne lub górne granice swobody rozstrzygnięcia”.

\subsection{Luz decyzyjny}

Wypełnianie różnych funkcji przez klauzule generalne jest możliwe dzięki utworzeniu przez te klauzule luzu decyzyjnego. Luz decyzyjny to zwykle celowo i świadomie dany przez ustawodawcę zakres swobody udzielonej stosującemu prawo w konkretnej sytuacji decyzyjnej. Luz decyzyjny daje możliwości wyboru dowolnego wariantu spośród określonego zbioru możliwości wyznaczonych

66 Can. I222 $\$ 2$ : „Ubi aliae graves causae suadeant ut aliqua ecclesia ad divinum cultum amplius non adhibeatur, eam Episcopus dioecesanus, audito consilio presbyterali, in usum profanum non sordidum redigere potest, de consensu eorum qui iura in eadem sibi legitime vindicent, et dummodo animarum bonum nullum inde detrimentum capiat".

67 Zob. A. Malinowski, Polski tekst prawny. Opracowanie treściowe i redakcyjne, Warszawa 20I2, s. 44-50.

68 Tekst jedn. Dz.U. z 2016 r. poz. 283. 
przez stosowaną normę prawną ${ }^{69}$. Jest on bardzo ważny przy decyzjach administracyjnych i nabiera szczególnego znaczenia przy rozstrzygnięciach podejmowanych przez sądy ${ }^{70}$. Sędziowie bowiem mają zwykle najszersze możliwości dyskrecjonalnego podejmowania rozstrzygnięć wiążących ${ }^{71}$. Jak podkreślił Trybunał Konstytucyjny: „nie można wyobrazić sobie prawidłowo działającego systemu prawnego i społecznego, który by eliminował istnienie wyrażeń i zwrotów niedookreślonych w prawie. Taki system musiałby charakteryzować się bardzo wysokim stopniem kazuistyki” ${ }^{72}$. Przez to byłyby on nieelastyczny i musiałby prowadzić do rozstrzygnięć niesprawiedliwych. Bez istnienia luzu decyzyjnego sądy „byłyby sprowadzone do roli automatu subsumcyjnego”.

Luz decyzyjny jest jawny, gdy jest dany rozmyślnie na etapie stanowienia prawa. Może być wynikiem zastosowania przez prawodawcę nie tylko klauzul generalnych, ale także zwrotów niedookreślonych, poprzez wyznaczenie normatywne granic decyzji czy poprzez posługiwanie się zwrotami typu „w szczególności”, które powodują, że katalog przesłanek powstawania obowiązów prawnych jest otwarty (np. kan. 777 KPK - peculiari modo i kan. $428 \$ 2$ KPK - speciatim) oraz przez uznanie administracyjne wyrażone zwrotem „w miarę możności” (np. $\$$ I3 SKKM, a także kan. 568, kan. I490, kan. I702 KPK - quatenus fieri possit, kan. $668 \$ 4 \mathrm{KPK}$ - quantum fieri potest). Zwrotami o identycznym charakterze są wyrażenia: „w miarę potrzeby” ( $\$ 4$ ust. I SWPAKP, art. III $\$ 3$ SKSM, $\$$ I8 ust. I SKKM), „W miarę możności” ( $\$ 6$ ust. I SMZR2009) oraz „W miarę swych możliwości” (art. I4, ust. I pkt a i art. I4 ust. 2 PWKE-R).

Dla porządku trzeba dodać, że można mówić o luzie decyzyjnym ukrytym, spowodowanym zastosowaniem wadliwego języka przez prawodawcę lub przez to, że teksty prawne są formułowane w języku, którego wieloznaczność wyrażeń jest cechą immanentną, niedającą się do końca usunąćç

Luz decyzyjny trzeba odróżnić od ideologii związanej z decyzją stosowania. Ideologia ta jest to całokształt postulatów i ocen na temat tego, jak dany organ

69 Por. M. Król, Pojęcie luzu normatywnego stosowania prawa, „Państwo i Prawo” (1979) z. 6, s. 62-72.

70 J. P. Dawson, The General Clauses Viewed From a Distance, „Rabels Zeitschrift für ausländisches und internationales Privatrecht" 4I (1977) Heft 3, s. 450.

7I Zob. M. Śliwka, Znaczenie zwrotów niedookreślonych na tle orzecznictwa polskiego Trybunatu Konstytucyjnego, „Studia Iuridica Lubliniensia” I3 (2010), s. 26I-272.

72 Wyrok Trybunału Konstytucyjnego z dnia 9 października 2007 r., sK 70/o6, Legalis nr 87215 .

73 Por. S. Wronkowska, Podstawowe pojęcia prawa i prawoznawstwa, Poznań 2005, s. I44. 
powinien stosować prawo. Zawiera ona w sobie nie tylko stosunek do prawa jako zjawiska, ale także do prawa stanowionego i obowiązującego. W przypadku kościołów i innych związków wyznaniowych elementem ideologii stosowania prawa będzie ich doktrynalny stosunek do prawa (o czym było w II rozdziale niniejszej książki). Dodatkowo ideologię stosowania prawa charakteryzują wartości, które organ ma obowiązek realizować. W szczególności są to takie wartości, jak: praworządność, pewność, obiektywność, sprawiedliwość, słuszność, racjonalnośćc ${ }^{74}$.

Ideologia ta, w przypadku Kościoła katolickiego, jest wyrażana w dokumentach o charakterze doktrynalnym lub normatywnym. Przykładowo, Wstęp do kodeksu prawa kanonicznego z 1983 r. zawiera historyczne umocowanie roli i znaczenia prawa, a także jego stosowania we wspólnocie - odwołuje się do synodu toledańskiego IV z r. 633, „który po przywróceniu dyscypliny Kościoła w królestwie Wizygotów wyzwolonego od arianizmu, przepisał: «Niech znają kapłani Pisma święte i kanony», ponieważ «nieznajomość, matka wszystkich błędów, zwłaszcza u kapłanów Bożych powinna być unikana» (kan. 25)”. Prawo jest popierane i cenione, taką postawę wobec prawa się nakazuje.

Jeżeli chodzi o elementy stosowania prawa, to implicite zawierają je zasady odnowy kodeksu prawa kanonicznego ${ }^{75}$. Ważna jest w tym kontekście zasada nr 3 o brzmieniu: „Dla jak najlepszego popierania troski duszpasterskiej, w nowym prawie, oprócz cnoty sprawiedliwości ma być także uwzględniona miłość, umiarkowanie, ludzkie podejście, umiar, których stosowność ma być uwzględniona nie tylko w aplikacji praw przez pasterzy, lecz także w samym ustawodawstwie, a zatem normy zbyt surowe mają być odrzucone, należy raczej posługiwać się zachętami i radami, gdzie nie zachodzi konieczność ścisłego przestrzegania prawa ze względu na dobro publiczne i ogólną dyscyplinę kościelną" ${ }^{76}$. Jednakże absolutnie fundamentalną zasadą stanowienia prawa jest zasada salus animarum suprema lex (,zbawienie dusz najwyższym prawem”). Jak już wspomniano, w prawie kanonicznym Kościoła katolickiego stanowi ona podstawę dla aplikacji norm ${ }^{77}$. Wyraża ją expressis verbis kan. 1752 z kodeksu prawa kanonicznego z $1983 \mathrm{r}$.

74 Por. W. Gromski, Ideologia stosowania prawa, [w:] A. Bator i inni, Wprowadzenie do nauk prawnych..., dz. cyt., s. 272-273.

75 Zob. Wstęp, [w:] кPK, s. 25 i 27.

76 Wstęp, [w:] KPк, s. 25.

77 Por. M. Wijlens, Salus animarum suprema lex..., dz. cyt., s. 588. 


\subsection{Skutki funkcji klauzul generalnych}

Skutki funkcji pełnionych przez klauzule generalne można podzielić na:

I. skutki pożądane,

2. skutki niepożądane.

Ad I. Istnieje wiele pożądanych skutków stosowania klauzul generalnych. Przede wszystkim klauzule generalne przyczyniają się do elastyczności tekstu normatywnego. Dzięki tej cesze tekst normatywny może, w odpowiednim zakresie, pozwolić na ${ }^{78}$ :

a. indywidualizację $\mathrm{w}$ stosowaniu norm prawa poprzez powierzenie luzu decyzyjnego organom stosującym prawo,

b. szersze uwzględnienie ogólnych zasad prawa oraz zasad danej gałęzi prawa względnie zasad regulacji danej materii,

c. złagodzenie rygoryzmu prawa i umożliwienie poszukiwania ius aequum dla każdego konkretnego przypadku,

d. korekturę sztywnych rozwiązań dyktowanych przez przepisy prawa,

e. szerokie otwarcie na przypadki niestandardowe,

f. uelastycznienie systemu prawa,

g. elastyczne kształtowanie sytuacji prawnej bez stosowania rozwiązań nadmiernie kazuistycznych,

h. zachowanie zasad prawno-dogmatyczno-moralnych kościoła lub innego związku wyznaniowego bez konieczności odrzucenia normy prawnej jako nieobowiązującej z uwagi na niezgodność z doktryną,

i. nadanie stosowaniu prawa bezpośredniego wymiaru aksjologicznego,

j. realizację określonych wartości, które są nadrzędne wobec normatywnej treści przepisu,

k. unikanie nadmiernej szczegółowości przy stanowieniu przepisów, która jest z punktu widzenia techniki legislacyjnej niepożądana ${ }^{79}$,

1. łączenie dobra indywidualnego i dobra wspólnego,

78 Zob. np. J. Nowacki, O przepisach zawierajacych klauzule generalne, dz. cyt., s. I35-I36; M. Safjan, Klauzule generalne w prawie cywilnym (przyczynek do dyskusji), dz. cyt., s. 5 I.

79 Por. $\$ 5$ „Zasad techniki prawodawczej”: „Przepisy ustawy redaguje się zwięźle i syntetycznie, unikając nadmiernej szczegółowości, a zarazem w sposób, w jaki opisuje się typowe sytuacje występujące w dziedzinie spraw regulowanych tą ustawą". 
m. łączenie pewności prawnej (decyzja oparta jest na literalnym brzmieniu przepisu) z niezbędną elastycznością szacowania (gdy pozostawiona została duża dyskrecjonalność organowi w procesie stosowania prawa).

Wszystko to może w rezultacie sprawić, że rozstrzygnięcia będą bardziej odpowiadały zasadom sprawiedliwości i słuszności.

Ad 2. Niekiedy zastosowanie klauzul generalnych, zwłaszcza ogólnikowo sformułowanych, zagraża pewności prawa i praworządności oraz jego stosowaniu. Zakres luzu decyzyjnego wynikający z klauzuli generalnej może spowodować wypaczenie mentis legislatoris.

W tym miejscu należy zauważyć, że pewne $\mathrm{z}$ wymienionych w punkcie I skutków funkcji klauzul generalnych (szczególnie „c”, „e”, „f”, „g” i „h”) są charakterystyczne dla innych katolickich instytucji prawnokanonicznych, a mianowicie dyspensy (dispensatio) lub przywileju (privilegium). Dyspensa to rozluźnienie prawa czysto kościelnego w poszczególnym wypadku (kan. 85 KPK), czyli ze względu na słuszne i racjonalne przyczyny (kan.90 KPK), którymi mogą być: okazanie miłosierdzia, dobro dusz, pożytek Kościoła, okoliczności osób miejsca i czasu ${ }^{80}$. Przywilej natomiast to konkretny akt administracyjny zawierający jakąś łaskę (dla osoby fizycznej lub prawnej), a więc zawsze korzystny dla adresatów (kan. $76 \$$ I KPK). Upoważnia on do działania contra legem lub praeter legem ${ }^{81}$.

Oznacza to, że w systemie prawa polskiego, które ma charakter pozytywistyczny, klauzule generalne będą bardziej istotnym i częściej używanym narzędziem w ręku prawodawcy niż w przypadku prawa kanonicznego. Będą one także pełnić nieco inne funkcje.

\subsection{Podział klauzul generalnych}

W polskiej jurysprudencji istnieją różne podziały klauzul generalnych ${ }^{82}$. Są one bardzo niejednoznaczne i odmienne u różnych autorów. Ogólny przegląd

80 Por. J. Krukowski, Dyspensy, [w:] J. Krukowski, R. Sobański, Komentarz do Kodeksu Prawa Kanonicznego, dz. cyt., s. I48-I49.

8I Por. J. Krukowski, Komentarz do kan. 76, [w:] J. Krukowski, R. Sobański, Komentarz do Kodeksu Prawa Kanonicznego, dz. cyt., s. I40.

82 Por. T. Zieliński, Klauzule generalne w prawie pracy, dz. cyt., s. 36-37. 
opinii na ten temat zawartych w literaturze prawniczej skłania do stwierdzenia, że w prawoznawstwie brak jasności i konsekwencji odnośnie do tej kwestii ${ }^{83}$.

Na użytek niniejszego opracowania, w związku ze specyfiką prawa związów wyznaniowych, klauzule generalne zostaną podzielone na dwa typy. Kryterium podziału jest jednoznaczna, specyficzna i dominująca cecha klauzuli pozwalająca na zaliczenie jej do określonej grupy ${ }^{84}$. Trzeba przy tym zaznaczyć, że co do zasady, każda klauzula generalna posiada wszystkie cechy konstytutywne dla tego typu wyrażeń, jednak nasilenie tych cech może być różne w poszczególnych klauzulach.

A. Klauzule generalne I typu. Klauzule generalne należące do tego zbioru cechuje to, że wyraźnie odsyłają poza system, czyli do zbioru reguł i ocen, wartości niebędących elementami systemu prawnego. W tym typie można wyróżnić podtypy:

Podtyp A - są to klauzule związane bezpośrednio z nauczaniem doktrynalno-moralnym kościoła lub innego związku wyznaniowego, takie jak: firma fides („niezachwiana wiara”) w kan. $378 \$$ I nr I KРк, certa fides („pewna wiara”) z $5 \mathrm{I} 2 \$ 3 \mathrm{KPK}$, bonae mores („dobre obyczaje”) (kan. $378 \$$ I nr I, kan. 5 I2 $\$ 3$, kan. $823 \$$ I KPK). Inną ilustracją omawianego podtypu zwrotów jest wyrażenie „dobry przykład” ( $\$ 34$ pkt 3 ZPWKE-A), a także „powaga Kościoła” ( $\$ 8$ ust. I ZPWKE-A) $\mathrm{i}$ „chrześcijański styl życia” (art. 4 ZPWкCHв). Do tej grupy należy zaliczyć również klauzule generalne „wysokie biblijne kwalifikacje duchowe, moralne i intelektualne” (art. 47 ust. I ZPWкснв). Klauzulę generalną prezentowanego typu zawiera także przepis „Diakon musi odpowiadać kwalifikacjom Pisma Świętego" (art. 37 ust. 3 PwKz).

Podtyp B - są to klauzule nieodwołujące się bezpośrednio do doktryny lub moralności danego kościoła lub innego związku wyznaniowego, lecz raczej odsyłające do ogólnoludzkich wartości. Prawodawca kościelny odwołuje się przykładowo do terminu aequitas („słuszność”) w kan. 22I

83 Por. T. Zieliński, Klauzule generalne w prawie pracy, dz. cyt., s. 4I. Artykuł M. Zielińskiego i Z. Radwańskiego, Uwagi „de lege ferenda” o klauzulach generalnych..., dz. cyt. porządkuje dyskusję, ujednolicając terminologię.

84 Por. Z. Ziembiński, Stan dyskusji nad problematyka klauzul generalnych, „Państwo i Prawo" (1989) z. 3, s. I7; A. Redelbach, S. Wronkowska, Z. Ziembiński, Zarys teorii państwa i prawa, Warszawa I992, s. 262-263; S. Wronkowska, Podstawowe pojęcia prawa i prawoznawstwa, dz. cyt., s. 68; S. Wronkowska, M. Zieliński, Komentarz do zasad techniki prawodawczej, Warszawa 2004, s. 296. 
\I, kan. $686 \$$ I, kan. 702 \I KPK oraz do wyrażenia naturalis aequitas („słuszność naturalna”) w kan. $27 \mathrm{I} \$ I, kan. II48 $₫$ I кPк. Te instytucje prawne znane są od starożytności i do dziś stosowane w nowoczesnych świeckich systemach prawnych. Inaczej by się rzecz miała, gdyby słuszność ta była jakoś ukonkretniona, jak to ma miejsce w przypadku terminu aequitas canonica („słuszność kanoniczna”), która w prawie kanonicznym Kościoła katolickiego ma długą historię ${ }^{85}$. Jest ona słusznością par excellence, gdyż jest inspirowana przez ducha miłosierdzia, dobroci i miłości, czyli cechy charakterystyczne dla Kościoła katolickiego i jego prawa ${ }^{86}$. Obecnie klauzula ta występuje w kan. I9 i kan. 1752 KPK. Należy ją zaliczyć do klauzul generalnych podtypu A.

B. Klauzule generalne II typu. Klauzule generalne tego typu posiadają charakter wszechstronnie oceniający, a więc wymagają od podmiotów stosujących prawo określonego oceniania, dokonanego zgodnie z treścią klauzuli. Egzemplifikacją tego typu klauzul mogą być wyrażenia: iusta et proportionata causa („słuszna i proporcjonalna przyczyna”) z kan. I89 \$2 KPK, iusta et rationabilis causa - w kan. $90 \$$ I („słuszna i racjonalna przyczyna”), kan. 83I $\$ I, kan. 906 (tu wyrażenie tłumaczone jako „słuszna i uzasadniona przyczyna”), kan. II25 (tu tłumaczone jako „słuszna i rozumna przyczyna”), iusta et necessaria causa - w kan. I308 $\$$ I, kan. I3IO $\$$ I („słuszna i konieczna przyczyna”).

Porównując typ I i typ II klauzul generalnych, należy stwierdzić, że typ II daje większą swobodę (luz decyzyjny) organowi stosującemu prawo. Oczywiście, „Cechą przepisów zawierających klauzule generalne jest to, że podmiot stosujący prawo musi przeprowadzić ocenę. W wyniku tego procesu powstaje dopiero norma konkretno-indywidualna, którą sędzia ad usum może zastosować" ${ }^{87}$. Jednakże w przypadku typu II możliwości decyzyjne są większe. Podmiot ma bowiem do dyspozycji zwrot, który ze swej natury jest nieostry lub niedookreślony.

Trzeba pamiętać, że swobody decyzyjnej nie należy utożsamiać z dowolnością rozstrzygnięć dokonywanych w procesie wykładni. Reguły wykładni (normatywne lub doktrynalne) muszą zostać zachowane.

85 Szerzej zob. M. Amen, Canonical Equity before the Code, „The Jurist” 33 (1973), s. 4-24; J. J. Coughlin, Canonical Equity, „Studia Canonica” 30 (1996), s. 403-435.

86 Por. P. Kroczek, The Art of Legislation..., dz. cyt., s. 237.

87 A. Piaskowy, Klauzule generalne w projekcie..., dz. cyt., s. 52. 


\subsection{Poszukiwanie desygnatów klauzul generalnych}

Jak już podkreślono, klauzule generalne, jako takie, mają charakter odsyłający. Trzeba przy tym zaznaczyć, że pozasystemowe reguły i zasady, do których odsyłają normy prawne, przez sam fakt odesłania do nich nie stają się normami prawnymi. „Niemniej ich przestrzeganie może być obowiązkiem adresata normy odsyłającej" ${ }^{88}$. Rysuje się w tym miejscu problem poszukiwania znaczenia klauzul generalnych, który można rozwiązać poprzez wskazanie źródeł aksjologicznych, specyficznych dla kościołów i innych zwiąków wyznaniowych.

\subsection{1. Źródła aksjologiczne}

Przepisy zawierające klauzule generalne odsyłają poza prawo. Poszukiwanie wskazówek odnośnie do ustalenia źródeł aksjologicznych dla prawa związów wyznaniowych należy rozpocząć od samego prawa.

\subsubsection{Wartości w prawie religijnym}

Prawo samo w sobie jest wartością dla społeczności ludzkiej z powodu funkcji, które wypełnia, czyli rezultatów aplikacji norm prawnych w życie adresatów, dla których zostało ono ustanowione ${ }^{89}$. Doktryna prawnicza wymienia wiele funkcji prawa, m.in. stabilizacyjną, dynamizującą, ochronną, organizacyjną, represyjną, wychowawcza, kontrolną, dystrybutywną, regulującą konflikty ${ }^{\circ}$. Funkcje te występują także w prawie religijnym, choć niekiedy - z powodu niewielkiego zakresu normatywnego prawa poszczególnych kościołów lub innych związków wyznaniowych - w stopniu znikomym.

Prawo jest także nośnikiem wartości w tym sensie, że chroni i broni wartości ważnych z punktu widzenia ustawodawcy lub społeczności. Widać dość jasno, że w przypadku prawa państwowego sfery prawa i moralności oddziałują na siebie. $Z$ jednej strony treść norm jest kształtowana przez moralność, z drugiej zaś

88 Wyrok Trybunału Konstytucyjnego z dnia 7 grudnia I999 r., к 6/99, Legalis nr 45625 .

89 Por. P. Kroczek, The Art of Legislation..., dz. cyt., s. 43.

90 Por. T. Chauvin, T. Stawecki, W. Winczorek, Wstęp do prawoznawstwa, Warszawa 20II, s. I68-I69. 
prawo kształtuje przekonania moralne. O ile w prawie stanowionym w ramach państwa świeckiego, opierając się na założeniach pozytywizmu prawniczego, można postawić tezę lub raczej postulat o rozdziale prawa i moralności, to w przypadku prawa religijnego takie oddziaływanie jest regułą. Stopień oddziaływania treści doktrynalno-moralnych i prawa jest bardzo wysoki; znacznie przewyższający ten istniejący w przypadku państw laickich, takich jak Polska9 ${ }^{91}$.

Wydaje się, że w prawie każdego związku wyznaniowego istnieją uniwersalne wartości religijnie czy międzykonfesyjne, to znaczy wspólne wszystkim prawom własnym kościołów i innych związków wyznaniowych. Mogą to być wartości związane z religią, jako fenomenem poddania człowieka bóstwu, czy też wartości ogólnoludzkie, akceptowane lub promowane przez religię jako taką. Jednakże do takich uniwersalnych wartości religijnych należy podchodzić z rezerwą i ostrożnością. Raczej należy grupując religie, w tym stosując kryterium doktrynalne, doszukiwać się wspólnych wartości obecnych w prawie endogenicznym związków należących do jednej grupy. Nie można bowiem zakładać, iż wszystkie wartości w prawie chrześcijańskim będą się treściowo pokrywać z wartościami w innych prawach religijnych. Powodem jest to, że kluczowe dla uznania tych wartości jest uznanie osoby Jezusa Chrystusa jako Boga i Zbawiciela ${ }^{92}$. Wartości w prawie chrześcijańskim skupione są wokół najważniejszej z nich - zbawienia, którego nie można zrozumieć bez wiary w Chrystusa. Co więcej, to Jezus Chrystus jest najwyższym prawodawcą dla chrześcijan. Każde prawo chrześcijańskiego Kościoła musi być zgodne z prawem Chrystusa. „To be a Christian has always meant to be someone who is subject to the law of Christ, who freely subjects himself to the law of Christ"93. Pragnienie uzyskania zbawienia wiąże się ściśle z przestrzeganiem Dekalogu i zasad podanych przez Jezusa w Ewangelii, a te znalazły swoją normatywną wersję w prawie Kościołów chrześcijańskich.

9I Por. L. Morawski, Gtówne problemy wspótczesnej filozofii prawa. Prawo w toku przemian, Warszawa 1999, s. 270-271. Więcej o filozoficznych poglądach na temat obecności moralności w prawie zob. S. Condor, Interpretation of Legal Discourse, Create Space Independent Publishing Platform 2013, s. 247-26I.

92 Por. T. L. Hall, „Incendiaries of Commonwealths”: Baptists and Law, [w:] Christian Perspective on Legal Thought, dz. cyt., s. 35I.

93 P. Kroczek, The Art of Legislation..., dz. cyt., s. 50: „Bycie chrześcijaninem zawsze oznaczało bycie kimś, kto jest poddany prawu Chrystusa, kto dobrowolnie poddaje siebie samego prawu Chrystusa" (przeł. P. Kroczek). 
W krajach, gdzie większość stanowią chrześcijanie, wartości te, poprzez proces stanowienia prawa, weszły do systemu prawa państwowego. Ustawodawca nie może bowiem stanąć niejako „poza sobą”. Akt ustawodawczy, jak każdy akt ludzki, ma w sobie coś z człowieka, który go dokonuje. Ustawodawca ma więc nie tylko określoną wiedzę prawniczą i kompetencje w tej dziedzinie, ale i określony światopogląd, wrażliwość, a te elementy są silnie kształtowane przez osobistą wiarę lub kulturę, w której ustawodawca wzrastał i w ramach której stanowi prawo. Jednakże wartości chrześcijańskie są obecne w prawach państw współczesnych jedynie w wersji ograniczonej i wybiórczej, nawet jeżeli większość z obywateli to chrześcijanie ${ }^{94}$. W końcu to sam Chrystus powiedział „Królestwo moje nie jest z tego świata” (J I8, 36).

Prawodawca religijny nie może zachowywać „aksjologicznej neutralności” w stanowionym przez siebie prawie. Musi uwzględnić treści doktrynalno-moralne swojego wyznania na wszystkich etapach stanowienia prawa, do których można zaliczyć: świadomość kompetencji prawodawczej, wgląd w sytuację adresatów prawa (wspólnoty wiernych), konsultacje z wiernymi, podejmowanie decyzji o konieczności stanowienia prawa, redagowanie ustawy, promulgacja ustawy ${ }^{95}$. Szczególnie na etapach takich jak: określanie celów ustawy, dokonywanie oceny konkurencyjnych ewaluacji projektów, czy też wyboru jednego z tych projektów prawodawca musi uwzględnić aksjologiczne uwarunkowanie decyzji, jakie podejmuje. Rzymska zasada „Quod principi placuit legis habet vigorem" ${ }^{96}$ nie ma pełnego zastosowania w prawie religijnym. Prawo to bowiem ma pełnić funkcję nie tylko ustanawiającą, organizacyjną czy porządkową, ale także wartościująca, wychowującą czy pouczającą, choć oczywiście przy wypełnianiu funkcji wymienionych wcześniej rolę odgrywa również religia.

Dualizmy: prawda-fałsz, dobro-zło są w prawie religijnym obecne dlatego, że prawo stanowione we wspólnotach religijnych przenika się z doktryną religijną. Nie przekreśla to wcale prawnego charakteru prawa religijnego, lecz pokazuje jego specyfikę. Wartościowanie wskazane wyżej, dokonane przez prawodawcę, przesądza o konkretnych rozwiązaniach prawnych i instytucjach

94 Por. K. Daniel, Kontrowersje wokót wprowadzenia wartości chrześcijańskich do prawa, [w:] Dynamika wartości w prawie, red. K. Pałecki, Kraków 1997, s. 157-207.

95 Por. P. Kroczek, The Art of Legislation..., dz. cyt., s. I76-186.

96 Iustiniani digesta, [w:] Corpus iuris civilis, editio stereotypa, vol. I, recognovit T. Mommsen, Berolini I872, I, 4, I - „To, co podoba się władcy, ma siłę prawa” (przeł. P. Kroczek). Por. Iustiniani institutiones, [w:] Corpus iuris civilis, editio stereotypa, volumen prius, recognovit P. Krüger, Berolini I872, I, 2, 6. 
prawnych, ale także o samym procesie stanowienia prawa, jego wykładni czy stosowaniu ${ }^{97}$.

Biorąc to wszystko pod uwagę, należy stwierdzić, że klauzule generalne w prawie kościołów i innych związków wyznaniowych, odsyłając do specyficznego dla każdego z osobna związku wyznaniowego systemu norm, wartości i ocen, będą odsyłać zasadniczo do dwóch zbiorów. Zbiory te są powiązane ze sobą logicznie, lecz zawsze w obrębie danej religii czy wyznania ${ }^{98}$. Po pierwsze, klauzule te odsyłają do zbiorów wartości i ocen typowych, lecz niejednakowych dla każdej religii, do których trzeba zaliczyć wartości i oceny związane z takimi obszarami, jak: stosunek do transcendencji, szacunek dla sacrum, przyjmowanie objawienia, wiarę w życie pozagrobowe, złączenie osobistej wiary i postawy życiowej, czyli do religijności jako takiej, przeżywanie łączności z innymi podzielającymi tę samą wiarę. Na tym polu mogą pomiędzy religiami istnieć duże podobieństwa. Po drugie, klauzule generalne odsyłają ponadto do ocen i wartości charakterystycznych dla danego związku wyznaniowego, które są zwykle uszczegółowieniem zasad z pierwszego zbioru, a więc dotyczą: ściśle określonego światopoglądu, konkretnej postawy wobec ważnych dla religii wartości.

Sumując, należy powiedzieć, że przez klauzule generalne prawo związków wyznaniowych odsyła głównie do wartości religijnych. Co więcej, prawo niezawierające, choćby dzięki temu odesłaniu, wartości, o których mowa, jest z punktu widzenia religijnego niepotrzebne ${ }^{99}$. Stanowiący prawo dla religijnej wspólnoty nie wypełniałby prawno-doktrynalnego założenia o racjonalności ubogaconej specyficznymi dla prawodawcy religijnego cechami. W prawie związków wyznaniowych wartości, do których odsyłają klauzule generalne, są powiązane z dogmatyczno-moralnymi zasadami kościoła lub innego związku wyznaniowego. System wartości Kościołów, czyli religijnych zrzeszeń chrześcijańskich, jest zbliżony, a różnice nie są fundamentalne, lecz konfesyjne. Inne związki wyznaniowe o pochodzeniu judaistycznym czy też islamskim mogą prezentować odmienne od chrześcijańskiego systemy wartości. Za każdym razem więc, przy szukaniu treści klauzuli generalnej, należy odwołać się do ściśle

97 Por. M. Borucka-Arctowa, Problem wartościowania w naukach prawnych, „Państwo i Prawo" (I968) z. 3, s. 429.

98 Por. Religia, [w:] D. Julia, Stownik filozofii, przeł. K. Jarosz, Katowice 1995, s. $345-349$.

99 Por. L. Örsy, Relation between Values and Laws, "The Jurist” 47 (1987), s. 477478 . 
określnego systemu wartości leżącego u podstaw prawa lub niekiedy będącego jego integralną częścią, do którego jednocześnie odsyłają klauzule generalne. Należy mieć tu na względzie zastrzeżenie poczynione wyżej w III rozdziale pod definicją klauzuli generalnej w prawie związków wyznaniowych. Zastrzeżenie to wskazuje na niepełną adekwatność cechy, jaką jest pozaprawne odesłanie klauzul generalnych w niektórych religijnych systemach prawnych.

\subsubsection{Zmienny charakter wartościowania}

Wartościowanie dokonane przez prawo religijne ma charakter zmienny i niejednokrotnie dynamiczny. Same bowiem kościoły i związki wyznaniowe modyfikują swoją doktrynę, co sprawia, że modyfikacji ulega także prawo oraz zbiory wartości i kryteria ocen, do których przepisy prawa odwołują interpretatora. We Wstępie do kodeksu prawa kanonicznego z 1983 r. ujęto to zagadnienie następująco: „Jeśli jednak, z powodu zbyt szybkich zmian współczesnej społeczności ludzkiej, pewne rzeczy już w czasie ustanawiania prawa stały się mniej doskonałe i w konsekwencji będą wymagać nowej rewizji, Kościół jest wyposażony w takie bogactwo sił, że nie inaczej jak w minionych wiekach będzie zdolny znaleźć drogę do ponownego odnowienia prawa swojego życia" ${ }^{\text {Ioo. }}$

Zmiany w samym prawie zwykle mają charakter ewolucyjny. Czasem jednak bywają one rewolucyjne. Nie wgłębiając się bardziej w naturę tych zmian, można powiedzieć, że w prawie związków wyznaniowych w pełni sprawdza się i ma zastosowanie zasada ius sequitur vitam („prawo podąża za życiem”) ${ }^{\text {10I. }}$. Nie można przecież regulować zmieniającego się życia wspólnoty przy pomocy niezmiennego prawa ${ }^{\mathrm{I02}}$.

Jako ilustracja takich zmian może posłużyć deklaracja o wolności religijnej

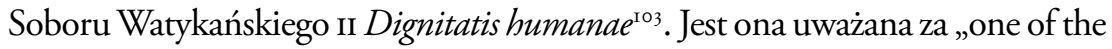

Ioo Wstę, [w:] Kodeks Prawa Kanonicznego..., dz. cyt., s. 37.

IOI Szerzej zob. P. Kroczek, „Ius sequitur vitam”, czyli o niektórych czynnikach zmian w prawie, „Studia Socialia Cracoviensia” 6 (20I4) nr 2 (II), s. I63-I76.

IO2 L. Örsy, The Interpretation of Laws: New Variations on an Old Theme, [w:] The Art of Interpretation. Selected Studies on the Interpretation of Canon Law, Washington I982, s. 66.

I03 Sacrosanctum Concilium Oecumenicum Vaticanum II, Declaratio Dignitatis humanae de libertate religiosa, 7.I2.1965, AAS 58 (1966), s. 929-946; tekst łacińsko-polski: Sobór Watykański II, Deklaracja o wolności religijnej Dignitatis humanae, [w:] Sobór Watykański II, Konstytucje, dekrety, deklaracje, Poznań 2008, s. 638-66I. 
major texts of the Council” (,jeden z głównych tekstów soboru”) ${ }^{\text {I04. Istnieją }}$ zasadniczo dwie główne opinie na temat tego dokumentu. Według pierwszej z nich poprzez tę deklarację nauczanie Kościoła katolickiego dotyczące wolności religijnej zostało zasadniczo i rewolucyjnie zmienione. Według drugiej dokument ukazuje ewolucję poglądów, która jest ograniczona właściwie tylko do odmiennego niż poprzednio rozłożenia akcentów i do zmiany języka. Istota zaś ujmowania wolności religijnej w nauczaniu Kościoła jest taka sama. Pod jej wpływem Kościół katolicki zmienił nastawienie do innych religii, co znalazło wyraz zarówno w prawie własnym, jak i konkordatach, które po II Soborze Watykańskim zawierano.

\subsubsection{Wprowadzenia do aktów normatywnych}

Poszukiwanie znaczenia klauzul generalnych wymaga zapoznania się na początku z deklaracjami kościołów lub związków wyznaniowych zawartymi we „wstępach”, „preambułach” czy „deklaracjach wstępnych” do statutów. Jak już pisano, wskazują one na specyficzny charakter teologiczno-prawny aktów normatywnych związków wyznaniowych. W tych wprowadzeniach podawane są wprost podstawy doktrynalne oraz moralne danego kościoła lub innego związku wyznaniowego oraz inne przydatne „zewnętrznemu interpretatorowi” informacje, takie jak:

I. Najważniejsze dogmaty wiary danego związku wyznaniowego: „Wszechmocny Bóg, Ojciec, Stwórca nieba i ziemi, który panuje nad wszystkim, co istnieje, posłał swego jedynego Syna, Jezusa Chrystusa, jako Zbawcę grzesznego stworzenia. On to mocą Ducha Świętego wybiera i gromadzi spośród całej ludzkości swój Kościół, rządzi nim jako jedyny Pan i jest jego Głową" (Wstęp, PWKE-R).

2. Pisma uważane za objawione przez związek wyznaniowy: „Kościół Ewangelicko-Augsburski w Rzeczypospolitej Polskiej jest społecznością [...] budującą swoją wiarę i życie chrześcijańskie wyłącznie na pismach Starego i Nowego Testamentu (Ef 4,4-6; I Kor I2,I2.I3; Rz IO,I7)" (Deklaracja wstępna, ZPWKE-A).

3. Fundamentalne dokumenty doktrynalne danego związku wyznaniowego: Kościół Ewangelicko-Reformowany w Polsce „Uznaje, że wykład zasad

IO4 J. C. Murray utrzymuje, że zdanie to wypowiedział papież Paweł vi. Zob. J. C. Murray, Religious freedom, dz. cyt., s. 674 . 
wiary został systematycznie przedstawiony w Katechizmie heidelberskim (I563), Drugiej konfesji helweckiej (I566) i w Konfesji sandomierskiej (I570). Za wzór formy nabożeństwa i innych posług religijnych przyjmuje Agendę gdańską (I637)” (Wstęp, PWKE-R), czy też: „Za ich obowiązujący wykład uznaje trzy starochrześcijańskie wyznania wiary (Apostolskie, Nicejsko-Konstantynopolskie, Atanazjańskie) oraz księgi wyznaniowe zawarte w Księdze zgody z r. 1580 (Maty katechizm, Duży katechizm, Wyznanie augsburskie, Obrona Wyznania augsburskiego, Artykuty szmalkaldzkie, Formuta zgody)" (Deklaracja wstępna, ZPWKE-A).

Choć z punktu widzenia teoretycznoprawnego wprowadzenia do aktów normatywnych nie mają znaczenia ściśle normatywnego, takiego jak tekst główny ustawy, to pełnią one znaczącą rolę w procesie wykładni prawa, w tym także w poszukiwaniu źródeł znaczeń klauzul generalnych ${ }^{\text {105 }}$.

\subsubsection{Przepisy tekstu głównego}

Czasami funkcję informacyjną mogą pełnić dla „zewnętrznego interpretatora” właściwe przepisy aktów normatywnych.

Przykładowo w $\$$ I Statutu Kościoła Katolickiego Mariawitów znajduje się deklaracja odnośnie do podstaw wiary Kościoła: „Kościół Katolicki Mariawitów opiera się na Objawieniu Bożym zawartym w Piśmie Świętym Starego i Nowego Testamentu, Tradycji św., do której głównie zalicza księgi liturgiczne i orzeczenia pierwszych siedmiu soborów ekumenicznych, na Objawieniu Bożym danym przez Świętą Marię Franciszkę, Założycielkę Mariawityzmu, zapowiedzianą w Piśmie Świętym na czasy ostateczne Oblubienicę i Małżonkę Chrystusową, oraz na Ustawach Kościoła Mariawickiego". Podobnie jest $\mathrm{w} \$ 2$ Statutu Kościoła Starokatolickiego Mariawitów.

Natomiast w art. I ust. 3. Prawa Wewnętrznego Kościoła Zielonoświątkowego w Rzeczypospolitej Polskiej zapisano: „[...] wierni Kościoła zielonoświątkowego wyznają swoją wiarę słowami apostolskiego i nicejsko-konstantynopolitańskiego wyznania wiary”. Analogiczny przepis znajduje się w art. 2 ust. I Statutu Kościoła Adwentystów Dnia Siódmego. Powyższe przepisy mają swoje porównywalne odpowiedniki w kan. 7 Prawa Wewnętrznego

Ios Zob. P. Kroczek, P. Skonieczny, Preamble of Law: Perspective of Legislator and Interpreter, „Angelicum” 90 (2013) fascicle 4, s. 869-888. 
Kościoła Polskokatolickiego i w art. I Zasadniczego Prawa Wewnętrznego Chrześcijan Baptystów.

Doktrynalną deklarację znaleźć można także w prawach religii niechrześcijańskich. Przykładowo w $\$ 2$ statutu karaimów: „Przepisy religijne KzR zawarte są wyłącznie w Piśmie Starego Testamentu", czy też w \$ I ust. 6 Statutu Muzułmańskiego Związku Religijnego z 2009 r.: „Podstawą przepisów religijnych jest Koran i Sunna” (\$ I ust. 6 SMZR2009; por. \24 pkt I SMZR2009, por. \2 SMZRI936).

\subsubsection{Poszukiwanie znaczeń klauzul generalnych}

Pewną formą pomocy w szukaniu znaczenia zwrotów, o których mowa, mogą być decyzje administracyjne, podejmowane przez właściwe organy kościołów lub innych związków wyznaniowych, orzeczenia sądowe i wykładnia autentyczna przepisów. Niestety, kościoły i związki wyznaniowe, poza Kościołem katolickim, a i ten w ograniczonym bardzo zakresie - nie udostępniły materiałów do analiz prawniczych. Powodem może być to, że nie dysponują one ugruntowaną tradycją prawniczą ani aktualnymi danymi w tym zakresie, pozwalającymi na posiłkowanie się zbiorami w celu ustalania znaczenia klauzul generalnych.

Trzeba także pamiętać, że konkretyzacja przepisów zawierających zwroty odsyłające do norm i ocen pozaprawnych może nastąpić tylko przy uwzględnieniu zindywidualizowanych okoliczności każdego przypadku. Stan faktyczny rozpoznawanej sprawy jest na tyle swoisty, że proste, bezkrytyczne, a zwłaszcza wybiórcze przenoszenie nań dotychczasowego dorobku administracji czy judykatury nie byłoby usprawiedliwione ${ }^{\mathrm{ro}}$.

\subsubsection{Decyzje administracyjne}

Określenie zakresu i znaczenia klauzul generalnych dokonywane jest przez organy władzy administracyjnej podczas wydawania rozstrzygnięć indywidualnych. Z praktyki wynika, że w Kościele katolickim najczęściej są to sytuacje prawne wynikające z okoliczności towarzyszących zawarciu małżeństwa. Można w tym obszarze wskazać kilka rodzajów sytuacji faktycznych, które mieszczą się albo nie mieszczą w znaczeniowym obszarze klauzul generalnych.

Io6 Por. Wyrok Sądu Najwyższego - Izba Pracy, Ubezpieczeń Społecznych i Spraw Publicznych z dnia 3 marca 2005 r., I PK 263/04, Legalis nr 70094. 
$\mathrm{Na}$ wstępie trzeba przypomnieć, że prawo kanoniczne zawiera przepisy określające przeszkody małżeńskie. Przeszkody to okoliczności, które czynią osobę niezdolną do ważnego zawarcia małżeństwa (kan. IO73 KPK). Mogą być one uchylone przez dyspensę (dispensatio). Zgodnie z kan. $87 \$$ I to biskup diecezjalny może dyspensować wiernych od prawa powszechnego (w którym ekskluzywnie zawarte są przeszkody do małżeństwa), ilekroć uzna to za pożyteczne dla ich "duchowego dobra” (spirituale bonum), zaś ordynariusz miejsca od ustaw diecezjalnych, a także, ilekroć uzna, że będzie to dla „dobra wiernych” (fidelium bonum).

Kluczowa dla rozważań jest norma z kan. 90 \ I zabraniająca dyspensowania od ustawodawstwa kościelnego, w tym także w zakresie przeszkód małżeńskich, chyba, że istnieje iusta et rationabilis causa („słuszna i racjonalna przyczyna”), którą trzeba uznać, uwzględniając okoliczności przypadku i ważności ustawy, od której się dyspensuje. „W przeciwnym razie dyspensa jest niegodziwa a także nieważna, chyba że została udzielona przez prawodawcę lub jego przełożonego" $(\text { kan. } 90 \$ \text { I KPK })^{107}$.

Przykładowy katalog przyczyn kanonicznych potrzebnych i wystarczających do udzielenia dyspensy sporządziła Kongregacja Rozkrzewiania Wiary w instrukcji z dnia 9 maja 1877 r. ${ }^{108}$. Wprawdzie powstał on na użytek porządku prawnego ustalonego przez poprzedni kodeks, czyli kodeks prawa kanonicznego z 1917 r., lecz wymogi udzielenia dyspensy były takie same (can. $84 \$$ I CIC). Katalog ten został, jak można się domyślać, sporządzony aposteriorycznie, czyli na podstawie wydanych decyzji. Zawiera on okoliczności, które, w kontekście przeszkód małżeńskich, pozwalają ustalić wartości istotne dla wspólnoty katolików. Dzięki temu można ustalić treść klauzul generalnych, takich jak: spirituale bonum, fidelium bonum oraz iusta et rationabilis causa.

Do omawianego zbioru okoliczności i faktów należą:

I. „Angustia loci sive absoluta sive relativa (ratione laetum Oratricis), cum scilicet in loco originis, vel etiam domicilii cognatio foeminae ita sit propagata” - okoliczność (absolutna albo względna), w której z racji niewielkiej liczby mieszkańców w miejscu swojego zamieszkania, kobieta nie może

I07 Can. 90 \$ I: „A lege ecclesiastica ne dispensetur sine iusta et rationabili causa, habita ratione adiunctorum casus et gravitatis legis a qua dispensatur; alias dispensatio illicita est, nisi ab ipso legislatore eiusve superiore data sit, etiam invalida”.

Io8 Congregatio de Propaganda Fide, Instructio super dispensationibus matrimonialibus, Ass is (I877), s. 29I-295. 
znaleźć nikogo odpowiedniego, jak tylko mężczyznę związanego przeszkodą, a jednocześnie nie ma możliwości, aby to miejsce zamieszkania opuścić.

2. „Aetas foeminae superadulta, st scilicet 24 aetatis annum iam egressa hactenus virum paris conditionis, cui nubere possit, non invenit" - wyższy wiek niewiasty. Pod koniec XIX w., czyli w czasie sporządzenia cytowanego katalogu, tą granicą wieku był 24 rok życia.

3. „Dotis deficientia aut incompetentia, si nempe foemina non habeat actu tantam dotem, ut extraneo aequalis" - brak posagu po stronie kobiety lub niedostateczna jego wielkość.

4. „Lites super successione bonorum iam exortae, vel earundem grave aut imminens periculum” - zażegnanie istniejących sporów o spadek lub zażegnanie groźby ich wystąpienia.

5. „Paupertas viduae, quae numerosa prole sit onerata, et vir eam alere polliceatur" - ubóstwo wdowy obarczonej licznym potomstwem.

6. „Bonum pacis, quo nomine veniunt nedum foedera inter regna, et Principes, sed etiam extinctio gravium inimicitiarum, rixarum, et odiorum civilium" dobro pokoju, przykładowo pomiędzy rodzinami.

7. „Nimia, suspecta, periculosa familiaritas, nec non cohabitatio sub eodem tecto, quae facile impediri non possit" - podejrzana poufałość osób i zamieszkanie razem.

8. „Copula cum consanguinea vel affine vel alia persona impedimento laborante praehabita, et Praegnantia, ideoque legitimatio prolis, ut nempe consulatur bono prolis ipsius, et honori mulieris, quae secus innupta maneret" - ciąża i potrzeba legitymizacji potomstwa.

9. „Infamia mulieris, ex suspicione orta, quod illa suo consanguineo aut affini nimis familiaris, cognita sit ab eodem [...]" - potrzeba ratowania dobrego imienia kobiety.

IO. „Revalidatio matrimonii, quod bona fide et publice, servata Tridentini forma, contractum est: quia eius dissolutio Vix fieri potest sine publico scandalo, et gravi damno, praesertim foeminae” - potrzeba „uważnienia małżeństwa” ${ }^{\circ o 9}$, czyli konwalidacji zawartego nieważnie w świetle prawa kanonicznego.

II. „Periculum matrimonii mixtii, vel coram acatholico ministro celebrandi” - niebezpieczeństwo zawarcia małżeństwa mieszanego albo zawarcie małżeństwa wobec celebransa niekatolickiego.

I09 Tak w polskim języku kanonicznym, zob. tłumaczenie np. kan. I080 $₫$ I. 
I2. „Periculum incestuosi concubinatus” - niebezpieczeństwo kazirodczego konkubinatu.

I3. „Periculum matrimonii civilis” - niebezpieczeństwo małżeństwa cywilnego.

I4. „Remotio gravium scandalorum” - konieczność zapobieżenia wielkiemu zgorszeniu.

I5. "Cessatio publici concubinatus” - ustanie publicznego konkubinatu.

I6. „Excellentia meritorum, cum aliquis aut contra fidei catholicae hostes dimicatione aut liberalitate erga Ecclesiam, aut doctrina, virtute, aliove modo de Religione sit optime meritus”- znaczne zasługi wobec Kościoła lub religii ${ }^{10}$.

Wartości, na które wskazują przytoczone okoliczności i fakty, są następujące:

I. życie w sakramentalnej wspólnocie małżeńskiej i tworzenie „wspólnoty całego życia" (totius vitae consortium), co umożliwia, w stanie łaski uświecającej, realizację celów małżeństwa, czyli dobra małżonków oraz zrodzenia i wychowania potomstwa (kan. IO55 $\$$ I KPK) - okoliczność pod numerami I, 2 i 3 ;

2. pokój pomiędzy wierzącymi - okoliczności pod numerami 4 i 6;

3. życie na godziwym materialnym poziomie wierzących - okoliczność pod numerem 5;

4. życie w stanie łaski uświęcającej - okoliczności pod numerami 7, I2, I3, I4 i I5;

5. dobra opinia osoby we wspólnocie osoby oraz dobry przykład dla wspólnoty - okoliczności pod numerami 8 i 9, I2, I3, I4 i I5;

6. zachowanie porządku kanonicznego we wspólnocie - okoliczności pod numerami IO i II, I2, I3, I5;

7. ogólne dobro wspólnoty wierzących czy całego Kościoła - okoliczności pod numerem 16.

Niektóre przyczyny z cytowanego wykazu wydają się być dziś nieadekwatne do rzeczywistości społecznej, w której znajdują się wierni. Nie można jednak mówić, że są one całkowicie anachroniczne ${ }^{11}$. Mutatis mutandis zachowują one

IIo Por. T. Pawluk, Prawo kanoniczne wedtug Kodeksu Jana Pawta II, t. 3, Prawo matżeńskie, Olsztyn 1996, s. II8.

III Tak twierdzi P. Majer, Odmowa (lub odroczenie) asystowania przy matżeństwie, [w:] Munus sanctificandi: gaudium vel onus? Zadanie uświęcania: radość czy ciężar?, red. B. W. Zubert, W. J. Sztyk, Katowice 2009, s. 66 (Szkoła Seraficka, 5). 
aktualność, a dodatkowo jasno pokazują produchowy, prokobiecy, prorodzinny i prospołeczny kierunek, w jakim powinno zmierzać ustalanie znaczeń treścią klauzul generalnych. Nota bene na ten katalog powoływała się Konferencja Episkopatu Polski w Instrukcji o kanonicznym badaniu narzeczonych przed ślubem z dnia 9 września $1946 \mathrm{r}^{\mathrm{II2}}$.

Kolejnym typem sytuacji prawnych, w których można poznać wartości ważne dla prawodawcy, jest zwolnienie od zapowiedzi małżeńskich, czyli publicznego ogłoszenia o zamiarze zawarcia małżeństwa. Takie zwolnienie wymaga dyspensy, a ta do swojej ważności - słusznej i racjonalnej przyczyny (art. I067 KPK oraz nr 95 Instrukcji o przygotowaniu do małżeństwa ${ }^{113}$ ). Za takie przyczyny w praktyce administracyjnej uważa się:

I. wyższy wiek narzeczonych ${ }^{\mathrm{Ir} 4}$ - co chroni wartość spokoju we wspólnocie i pozwala na unikanie sensacji czy niezdrowego zainteresowania nupturientami,

2. dobro dzieci ${ }^{115}$ - co jest już samo w sobie klauzulą generalną,

3. fakt wspólnego zamieszkania razem narzeczonych oraz, co się z tym wiąże, uznawanie ich przez otoczenie za prawdzie małżeństwo ${ }^{116}-$ co chroni wartość dobrego imienia zainteresowanych.

Wątpliwość natury teoretycznej i praktycznej musi budzić fakt, że wielokrotnie w praktyce administracyjnej jako okoliczność życiową zawierającą się w klauzuli generalnej do dyspensy czy też zezwolenia umieszcza się klauzulę generalną - dobro duchowe stron ${ }^{117}$. Jest to klauzula generalna, a nie okoliczność czy fakt, których podania prawo wymaga.

II2 Konferencja Episkopatu Polski, Instrukcja o kanonicznym badaniu narzeczonych przed ślubem z dnia 9 września 1946 roku, Olsztyn 1947, nr 31, s. I6-I7.

II3 Konferencja Episkopatu Polski, Instrukcja Episkopatu Polski o przygotowaniu do zawarcia małżeństwa w Kościele katolickim, 5 września 1986 r., „Akta Konferencji Episkopatu Polski” I (1998) nr I, s. 85-I37.

II4 Zob. Dekret z dnia I kwietnia 20I5 r., nr 724/20I5 oraz całość dokumentacji.

II5 Zob. Dekret z dnia I kwietnia 20I5 r., nr 724/20I5 oraz całość dokumentacji; Dekret z dnia I5 maja 2015 r., nr II53/20I5 oraz całość dokumentacji.

II6 Zob. Dekret z dnia I kwietnia 20I5 r., nr 724/20I5 oraz całość dokumentacji; Dekret z dnia I5 maja 20I5 r. nr II86/20I5 oraz całość dokumentacji; Dekret z dnia I5 maja 2015 r. nr II53/20I5 oraz całość dokumentacji.

II7 Zob. Dekret z dnia 6 lipca 20II r., nr I928/20II oraz całość dokumentacji; Dekret z dnia I3 maja 2010 r., nr I306/20Io oraz całość dokumentacji; Dekret z dnia 26 listopada 2009 r., nr 3363/2009 oraz całość dokumentacji; Dekret z dnia 3 lipca 2008 r., nr I80I/2008 oraz całość dokumentacji; Dekret z dnia I kwietnia 2015 r., 


\subsubsection{Orzeczenia sądowe}

Biskup Rzymski, jako najwyższy sędzia dla całego świata katolickiego, sądzi sprawy i wymierza sprawiedliwość przez trybunały Stolicy Apostolskiej. Zalicza się do nich: Rotę Rzymską, Najwyższy Trybunał Sygnatury Apostolskiej oraz Penitencjarię Apostolską (zob. kan. I442-I445 KPK). Instytucje te w swoich orzeczeniach dokonują niekiedy wyjaśnień klauzul generalnych.

Klauzula spirituale bonum („dobro duchowe”) np. z kan. 6I4, została przybliżona w Dekrecie Sygnatury Apostolskiej z dnia 25 czerwca 1994 r. ${ }^{118}$. W sprawie chodziło o to, że biskup diecezjalny połączył dwie parafie personalne, przekazując nowo powstałej parafii jeden z kościołów do użytku, drugi zaś z powodu złego stanu technicznego miał być rozebrany. Naprawa kościoła była bowiem niemożliwa bez poniesienia wydatków, także przez diecezję, które biskup nie uznał za zbyt wielkie. Od tej decyzji się odwołano.

W dekrecie rozstrzygającym tę sprawę sędziowie napisali, że biskup jako pasterz całej diecezji powinien troszczyć się o dobro duchowe wiernych, ale powinien to robić, mając na względzie całą diecezję, czyli wszystkich wiernych powierzonych jego pieczy. „Dobro duchowe” nie może być ustalane wyłącznie w oparciu o życzenia i pragnienia określonej grupy wiernych należących do parafii. Pożądane stany faktyczne, które w tym konkretnym przypadku mają status wartości, to dostęp do świątyni oraz unikanie nadmiernych wydatków na cele niekonieczne.

Inną klauzulę generalną, której znaczenie ustaliła kościelna władza sądownicza, jest klauzula bonum instituti („dobro instytutu”) z kan. 6I8 kodeksu prawa kanonicznego. Najwyższy Trybunał Sygnatury Apostolskiej, który m.in. rozpatruje spory powstałe na skutek działania kościelnej władzy administracyjnej, w dekrecie z dnia 9 maja 1992 r. ${ }^{119}$, napisał, że dopuszczalne było zastosowanie

nr 724/20I5 oraz całość dokumentacji; Dekret z dnia I8 marca 20I5 r., nr 548/20I5 oraz całość dokumentacji.

II8 Supremum Tribunal Signaturae Apostolicae, Decretum die 25 iunius 1994, prot. 24048/93 CA, [w:] Ministerium Iustitiae. Jurisprudence of the Supreme Tribunal of the Apostolic Signature. Official Latin with English Translation, transl. W. L. Daniel, Montreal 20II, s. 476-48I.

II Supremum Tribunal Signaturae Apostolicae, Decretum die 5 maii 1990, prot. I806I/86 CA, [w:] Ministerium Iustitiae. Jurisprudence of the Supreme Tribunal..., dz. cyt., s. $260-274$. 
wobec członka instytutu eksklaustracji (wyłączenia poza wspólnotę zakonną na określony czas, kan. $686 \$ \mathrm{I}-\$ 3 \mathrm{KPK}$ ) dla dobra instytutu. Fakt, że zakonnica poprzez swoje zachowanie poważnie zakłócała życie we wspólnocie, do której należała, upoważnił do podjęcia wspomnianej decyzji. Ocena jej zachowania była dokonana w oparciu o wartości, jakimi są spokój we wspólnocie i harmonijne ułożenie stosunków międzyludzkich.

\subsubsection{Wykładnie autentyczne}

Tylko trzy wykładnie autentyczne prawa Kościoła katolickiego zawierają klauzule generalne. Są to wykładnie kan. $236 \$$ I w związku z $402 \$ \mathrm{I}^{\mathrm{I20}}$, oraz wykładnia kan. ${ }^{2} 263^{\text {I2I }}$ i kan. $1737 \$ \mathrm{I}^{\mathrm{I} 22}$. Niestety, w oficjalnych publikatorach kościelnych podana jest tylko odpowiedź na konkretne pytanie związane z tymi przepisami. Nie podaje się toku rozumowania przyjętego przez organ dokonujący autentycznej wykładni przedmiotowych przepisów. Jednakże w pewnych okolicznościach nawet takie szczątkowe dane mogą być pomocne przy ustalaniu znaczenia klauzul generalnych.

\subsubsection{Wykładnia w formie ustawy}

Instrukcja Konferencji Episkopatu Polski o przygotowaniu do zawarcia małżeństwa $\mathrm{w}$ Kościele katolickim z dnia 5 września 1986 r. ${ }^{123}$ zawiera w $\mathrm{nr} 49$ wykładnię klauzuli generalnej iusta et rationabilis causa (,słuszna i racjonalna przyczyna") zawartej w wielu przepisach kodeksu. Instrukcja stanowi, że szukając przyczyn, dla których udziela się dyspensy - a więc jednocześnie wskazuje na wartości, do których odwołuje się cytowana klauzula generalna - „należy brać pod uwagę nie tylko obiektywne racje, ale przede wszystkim dobro duchowe wiernych". Oznacza to, że kodeksowy zwrot iusta et rationabilis causa, w każdym razie w kontekście małżeństwa, staje się tożsamy z wyrażeniem „dobro duchowe wiernych”, czyli ich konkretnego

I20 Pontificia Commissio Codici Iuris Canonici Authentice Interpretando, Responsiones ad proposita dubia ad can. $402 \$$ I, AAS 83 (I99I), s. IO93.

I2I Pontificia Commissio Codici Iuris Canonici Authentice Interpretando, Responsiones ad proposita dubia ad can. I263, AAS 8I (I989), s. 99I.

I22 Pontificia Commissio Codici Iuris Canonici Authentice Interpretando, Responsiones ad proposita dubia ad can. I737 \$ I, AAS 80 (I988), s. I8I8.

I23 „Akta Konferencji Episkopatu Polski” I (I998) nr I, s. 85-I37. 
interesu o charakterze religijnym. W analizowanym przypadku klauzula generalna zostaje wyjaśniona przez inną klauzulę generalną. Oczywiście ta wykładnia nie jest wykładnią autentyczną kodeksu - do tego Konferencja Episkopatu nie ma kompetencji.

Trzeba dodać, że w praktyce administracyjnej każda wartość, do której odwołują się proszący o dyspensę narzeczeni, jest uznawana przez kompetentną władzę za wartość, do której odsyłają wspomniane klauzule ${ }^{\text {r24 }}$.

Trzeba ponadto zaznaczyć, że przywołany dokument Konferencji Episkopatu Polski, mimo swojej nazwy - „instrukcja” - w rzeczywistości jest ustawą kościelną. Zawiera on bowiem treści normatywne, wprowadzając pewne novum do systemu norm, a ,instrukcja”, zgodnie z kodeksem, to dokument wydany przez władzę wykonawczą, który ma wyjaśniać przepisy ustaw oraz rozwijać i określać racje, jakie należy uwzględnić przy ich zachowaniu (kan. 34 \$ I KPK). Instrukcja jako taka nie może więc modyfikować istniejącego stanu normatywnego. Kodeks wyraża to następująco: „Postanowienia instrukcji nie zmieniają ustaw. Jeśli zaś któreś z nich nie dadzą się pogodzić z przepisami ustaw, są pozbawione wszelkiej mocy" (kan. $34 \$ 2 \mathrm{KPK}$ ). Można więc powiedzieć, że przywołaną instrukcją Episkopat dokonał w formie ustawy obowiązującej głównie duszpasterzy w Polsce praktycznej wykładni kodeksu.

\subsubsection{Doktryna prawnicza}

Doktryna prawnicza przybliża niekiedy znaczenie klauzul generalnych. Czyni to zwykle poprzez komentowanie przepisów zawierających te wyrażenia.

Dla przykładu kanoniczna klauzula bona fides („dobra wiara”) jest kategorią etyczną, od której jednak zależy zaistnienie skutków prawnych. Klauzula ta oznacza, że osoba znajdująca się w dobrej wierze jest rzetelnie przekonana (nie ma wątpliwości), i to przekonanie nie jest oparte na zawinionym błędzie

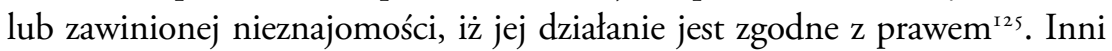
kanoniści nadają tej klauzuli charakter teologiczny, przejawiający się w aspekcie moralnym. Przyjmują oni, że dobra wiara w prawie kanonicznym to brak grzechu ciężkiego (absentia peccati), czyli uczciwe przekonanie o zgodności

I24 Por. P. Majer, Odmowa (lub odroczenie) asystowania przy matżeństwie, dz. cyt., s. 66-67.

I25 Por. R. Sobański, Komentarz do kan. 198, [w:] J. Krukowski, R. Sobański, Komentarz do Kodeksu Prawa Kanonicznego, dz. cyt., s. 289. 
z prawem działania lub zaniechania, które prowadzi do przedawnienia. Chodzi o wolność od winy moralnej ${ }^{\mathrm{i} 26}$.

Natomiast kanoniczna klauzula aequitas canonica („słuszność kanoniczna”) to znana prawnikom aequitas (,słuszność”), która została ubogacona przez myśl chrześcijańską odwołującą się do miłości Boga do człowieka. W stosowaniu prawa polega na złagodzeniu ścisłego prawa w konkretnym przypadku. Przy jej stosowaniu należy odwołać się do ducha miłosierdzia (misericordia), dobroci (benignitas), miłości (caritas), łagodności i wyrozumiałości. Składają się na tę klauzulę także prawda (veritas), dobro Kościoła (bonum Ecclesiae), zbawienie dusz (salus animarum) ${ }^{127}$. Tak więc można zdefiniować przedmiotowy termin jako stojącą nad prawem pozytywnym sprawiedliwość, wykonywaną ze względu na dobro duchowe lub inne dobro ${ }^{128}$.

Gdy chodzi o klauzulę iusta causa („słuszna przyczyna”), to w literaturze przedmiotu rozpatrującej sprawy związane z małżeństwem stwierdza się, że okoliczności życiowe i fakty wskazujące na wartości, do których odwołuje się ta klauzula, są następujące: choroba kobiety, brzydota fizyczna kobiety, przydatność danej kobiety dla wdowca obarczonego potomstwem, konieczna pomoc do prowadzenia gospodarstwa, stosowność stron do zawarcia małżeństwa, potrzeba wzajemnej pomocy, jeżeli strony są w podeszłym wieku, poczynione przygotowania do ślubu, rozgłoszenie zamiaru zawarcia małżeństwa, sieroctwo kobiety, niebezpieczeństwo niepowściąliwości grożącej młodej wdowie, niezaradność mężczyzny w znalezieniu odpowiedniej narzeczonej ${ }^{129}$. Kryteria, w oparciu o które dokonuje się wykładni klauzuli i dokonuje się rozstrzygnięcia stanu faktycznego, to takie wartości, jak: służebny charakter prawa kanonicznego, spokój we wspólnocie, unikanie niepotrzebnych kosztów, zachowanie przez wiernego stanu łaski uświecającej. Niekiedy uważa się, że już sam poważny zamiar zawarcia małżeństwa zawierający dobro duchowe

I26 Por. W. Aymans, K. Mörsdorf, Kanonisches Recht. Lehrbuch aufgrund des Codex Iuris Canonici, t. I: Einleitende Grundfragen und Allgemeine Normen, Paderborn I991, s. 508 .

I27 Por. T. Pawluk, Prawo kanoniczne wedtug Kodeksu Jana Pawta II, t. I, dz. cyt., s. 233; F. Bączkowicz, Prawo kanoniczne. Podręcznik dla duchowieństwa, dz. cyt., s. 2 Io.

I28 Por. Ch. Lefebvre, Équité, [w:] Dictionnaire de droit canonique, sous la direction de R. Naz, vol. 5, Paris 1953, kol. 400.

I29 Por. T. Pawluk, Prawo Kanoniczne wedtug Kodeksu Jana Pawta II, t. I, dz. cyt., s. II8. 
stron i potomstwa jest taką rozumną i słuszną przyczyną. Istnieją jednak głosy odmienne w doktrynie kanonistycznej ${ }^{\mathrm{i30}}$.

\subsubsection{Wykładnia religijna}

$\mathrm{Z}$ tej racji, że tekst normatywny jest wyrazem religijnych zasad dogmatyczno-moralnych, można przy poszukiwaniu jego znaczenia uciec się do interpretacji religijnej dokonanej przez duchownych. Dobrym przykładem mogą być interpelacje dokonane przez rabinów.

Klauzula „duch judaizmu” oznacza ogólny kierunek interpretacji wyznaczony przez religię żydowską. Następnie „zasady judaizmu” to podstawowe zasady wiary i zachowania żydów zawarte 6I3 nakazach i zakazach. Z kolei „zasady życia przodków” oznaczają ogólną tradycję judaistyczną, ale zawsze w połączeniu z tradycją lokalną tworzoną przez miejscową gminę.

\subsubsection{Wykładnia odnosząca się do świętych tekstów}

Znaczenie klauzul generalnych można poznać także poprzez odwołanie się do tekstów uważanych za święte na gruncie danej religii lub wyznania. Takie odwołanie do świętych tekstów zawiera przepis: „Diakon musi odpowiadać kwalifikacjom Pisma Świętego" (art. 37 ust. 3 PWKz). W tym przypadku należy odnieść się do pierwszego Listu św. Pawła do Tymoteusza z Nowego Testamentu. Stosowne wersy brzmią tak: „Diakonami tak samo winni być ludzie godni, w mowie nieobłudni, nie nadużywający wina, niechciwi brudnego zysku, [lecz] utrzymujący tajemnicę wiary w czystym sumieniu. I oni niech będą najpierw poddawani próbie, i dopiero wtedy niech spełniają posługę, jeśli są bez zarzutu. [...] Diakoni niech będą mężami jednej żony, rządzący dobrze dziećmi i własnymi domami. Ci bowiem, skoro dobrze spełnili czynności diakońskie, zdobywają sobie zaszczytny stopień i ufną śmiałość w wierze, która jest w Chrystusie Jezusie" (I Tym 3, 8-IO. I2-I3).

I30 Por. K. Gierat, Problematyka matżeństw mieszanych $w$ kontekście wypetniania istotnych praw-obowiązków matżeńskich, „Ius Matrimoniale” 5 (2000), s. 73. 


\subsubsection{Granice znaczeń klauzul generalnych}

Zasada określoności to zasada prawa nakazująca, aby przepisy prawne były formułowane w sposób precyzyjny, jasny oraz legislacyjnie poprawny ${ }^{131}$. Wymóg określoności należy rozumieć jako nakaz precyzyjnego wyznaczania dopuszczalnego zakresu ingerencji. Przez niejasne formułowanie przepisów ustawodawca nie może pozostawiać mającym je stosować organom nadmiernej swobody.

Zasada ta wprawdzie wywodzi się z zasady demokratycznego państwa prawnego zawartej w art. 2 Konstytucji, lecz jako postulat może być, jak się wydaje, zastosowana do każdego systemu prawnego, także prawa związków wyznaniowych, nie wyklucza posługiwania się przez ustawodawcę nazwami, które powodują uelastycznienie tekstu. Istnieje jednak warunek, że desygnaty tych nazw można ustalić w konkretnej sytuacji. Nie może to być jednak ustalane arbitralnie ${ }^{\mathrm{I} 32}$.

Opisana zasada powoduje, że klauzula generalna zawarta w przepisie nie oznacza dowolności interpretacyjnej, nawet przy zachowaniu reguł i norm dotyczących wykładni, i w rezultacie niejako zwolnienia od odpowiedzialności za wynik procesu wykładni. Użycie klauzul przez prawodawcę nie jest równoznaczne z przyznaniem interpretatorowi absolutnej i pozostającej poza wszelką kontrolą swobody, prowadzącej do podnoszonej „dowolności rozstrzygnięć”'

W zależności od przyjętej koncepcji wykładni klauzula generalna może stanowić dodatkowe zadanie dla dokonującego wykładni. Wykładnia prawa związków wyznaniowych powinna odbywać się zgodnie z zasadami stanowienia przepisów przyjętych w danym kościele lub innym związku wyznaniowym. To zagadnienie było szczegółowo opisywane w rozdziale II.

Można także powiedzieć, że organ, dokonując wykładni, jest zobowiązany, natrafiając na takie wyrażenie w tekście normatywnym, do szczególnej

I3I Zob. Wyrok Trubunału Konstytucyjnego z dnia I9 grudnia 2012 r., K 9/I2, Legalis nr 549608. Zob. Wyrok Trubunału Konstytucyjnego z dnia 28 października 2009 r., kp 3/09, Legalis nr 175631.

I32 Zob. Wyrok Trybunału Konstytucyjnego z dnia i6 stycznia 2006 r., sK 30/05, Legalis nr 72310.

I33 Wyrok Trybunału Konstytucyjnego z dnia I4 grudnia I999 r., sK I4/98, Legalis nr 45628. Zob. A. Redelbach, S. Wronkowska, Z. Ziembiński, Zarys teorii państwa i prawa, dz. cyt., s. 260-26I; A. Choduń, A. Gomułowicz, A. Skoczylas, Klauzule generalne $i$ zwroty niedookreślone $w$ prawie podatkowym $i$ administracyjnym..., dz. cyt., s. 38 . 
staranności w swoich działaniach, a zwłaszcza do wszechstronnej i szczegółowej oceny konkretnych okoliczności danej sprawie ${ }^{\mathrm{I} 34}$.

Ukształtowany w procesie stosowania prawa określony sposób rozumienia przepisu zawierającego klauzulę generalną może odbiegać od brzmienia, jakie nadał mu ustawodawca. Przy założeniu ortodoksji tekstu normatywnego, rozumianej jako wierność dogmatyczno-moralnym wartościom danego kościoła lub innego związku wyznaniowego, może zaistnieć taka sytuacja, że organy stosujące prawo, sądy i organy decyzyjne, w drodze wykładni prawa wydobędą z aktów normatywnych treści normatywne niemożliwe do pogodzenia z normami, zasadami lub wartościami, których poszanowania wymaga dany związek wyznaniowy ${ }^{135}$. Teoretycznie taka sytuacja jest możliwa. W praktyce jednak jest to bardzo rzadkie. Decyduje o tym kilka czynników.

Po pierwsze, norma sprzeczna z systemem religijnym danego kościoła lub związku wyznaniowego będzie formalnie obowiązywać, ale nie będzie miała mocy wiążącej. Granic niedookreśloności klauzul generalnych strzeże doktryna religijna, czyli zasady dogmatyczno-moralne, ale także zasady ustrojowe danego zrzeszenia religijnego. Rozstrzygnięcia i oceny teologiczne są niezbędnym i niepodważalnym elementem zarówno faktu istnienia normy, jak i jej brzmienia. Teologia kształtuje bowiem nie tylko fundament prawa, ale także konkretne rozwiązania w nim zawarte ${ }^{\mathrm{I} 36}$.

Po drugie, ustalenia granic znaczeniowych klauzul generalnych dokonuje także prawodawca - poprzez precyzowanie ich znaczenia. Może się to odbywać poprzez egzemplifikację najczęściej występujących form zjawiskowych danych czynności.

Po trzecie, swoboda wykładni jest ograniczona paradygmatem wykładni. Przede wszystkim norma uzyskana w jej wyniku nie może być sprzeczna z literalnym brzmieniem przepisu. W konsekwencji swoboda decyzyjna nie jest absolutna i nie powoduje dowolności rozstrzygnięć sądowych czy administracyjnych.

Po czwarte, na straży właściwego stosowania zasady stoją normy procesowe. Nakazują one wskazanie przesłanek, jakie legły u podstaw zastosowania

I34 Por. L. Morawski, Zasady wyktadni prawa, Toruń 20IO, s. 275.

I35 Por. Wyrok Trybunału Konstytucyjnego z dnia 27 października 20 Io r., K Io/o8, Legalis nr 254429 .

I36 Por. B. Gangoiti, Teologia e filosofia del diritto del nuovo codice, „Angelicum” 60 (1983), s. 517-518. 
w konkretnej sprawie normy prawnej skonstruowanej przy użyciu każdego pojęcia nieostrego, także klauzuli generalnej.

Po piąte, użycie zwrotów uelastyczniających wymaga istnienia szczególnych gwarancji proceduralnych, zapewniających przejrzystość i ocenność praktyki wypełniania tych zwrotów konkretną treścią przez organ decydujący o tym wypełnieniu. Oznacza to, że można postawić organowi postulat odpowiedniego proceduralnego podejścia do przedmiotowych wyrażeń znajdujących się w tekście prawa związku wyznaniowego.

Gdy chodzi o granice znaczeniowe klauzul generalnych, to trzeba ponadto zauważyć, że ich wykładnia nie może prowadzić do usunięcia czy też zawężenia związanego z klauzulą generalną luzu decyzyjnego. Jest on bowiem zamierzony przez prawodawcę. Wybór jednego wariantu ze spektrum możliwości, czyli konkretyzacja normy, następuje zwykle w procesie stosowania prawa w drodze wykładni ${ }^{137}$. Wykładni prawa można oczywiście dokonywać poza procesem stosowania prawa.

\subsection{Porównanie klauzul generalnych prawa związków wyznaniowych i prawa polskiego}

Dokonując analizy porównawczej pomiędzy klauzulami generalnymi stosowanymi przez ustawodawcę polskiego a tymi używanymi przez prawodawców związków wyznaniowych, można zauważyć formalne i treściowe podobieństwa oraz różnice pomiędzy tymi wyrażeniami.

Po pierwsze, cel używania klauzul generalnych jest ten sam i wypełniają one podobne funkcje zarówno w prawach związków religijnych, jak i w prawie polskim.

Po drugie, podobieństwa treściowe zawierają się w tym, że zarówno w prawie polskim, jak i prawie związków wyznaniowych istnieją klauzule, które odwołują się do ogólnoludzkich wartości, takich jak: ład, porządek, odpowiedzialność, solidność, zachowanie powszechnie przyjętego kanonu estetyki.

Po trzecie, różnice formalne pomiędzy klauzulami widać wyraźnie w przypadku klauzul, które zawiera prawo związków wyznaniowych, a które są zupełnie obce ustawodawcy polskiemu, takie jak: salus aminarum (,zbawienie

I37 Por. L. Morawski, Zasady wyktadni prawa, dz. cyt., s. 58-59. 
dusz") (kan. $1736 \$ 2$, kan. $1737 \$ 3$, kan. $1752 \mathrm{KPK}$ ) czy też spirituale bonum („dobro duchowe”) (kan. $87 \$$ I KPK).

Po czwarte, istnieją sytuacje, w których istnieje podobieństwo formalne klauzul, ale z różnicą w treści, do których się one odwołują. Klauzula zasad współżycia społecznego (art. 754 k.c.) odwołuje się do wewnętrznych zwyczajów lub wartości moralnych grupy społecznej. Formalnie jest więc podobna do klauzul, takich jak normae vitae christianae („zasady życia chrześcijańskiego”) (kan. 767 \$ І крк), jednak jej znaczenie będzie zupełnie inne. Inna para podobieństw to klauzula generalna „interes publiczny” często występująca w polskich aktach normatywnych, np. w art. I54 pkt 2I czy art. 192 ust. 5 Ustawy z dnia 29 stycznia 2004 r. Prawo zamówień publicznych ${ }^{138}$ oraz klauzula generalna interestum publicum („,interes publiczny”) z kan. I530 KPK, czy też „interes Kościoła” (art. 3 $\$ 8$ pkt a i art. VII $\$ 2$ lit. c SKSM, art. 37 pkt 2 SKADS) bądź ten sam zwrot w liczbie mnogiej - „interesy Kościoła” (art. II ust. 2 pkt I PWKZ). Zwroty te odsyłają do systemu ocen pozaprawnych, jednakże będą to inne systemy wartości.

Po piąte, jeżeli za pełniące funkcję klauzuli generalnej uznamy wyrażenie z konstytucji o zasadach demokratycznego państwa prawa ${ }^{139}$, to podobne odesłania do wartości ustrojowych można znaleźć w prawie związków wyznaniowych. Dla przykładu można podać klauzulę: „zasady religii muzułmańskiej” ( $\$ 44$ pkt 3 SMZR2009), ,zasady religijne i moralne judaizmu” (art. 9 pkt 2 PWwŻ), „zasady Kościoła” (art. 6 PWKE-R), „zasady religii karaimskiej” (\$ 35 lit. b sKzR), „zasady baptyzmu” (art. 4 ZPWкCHв), „zasady wyznania ewangelicko-reformowanego" (art. II, art. 35 ust. I, art. 36 PWKE-R) czy klauzulę principia ab Ecclesia tradita („zasady podane przez Kościół”, kan. I286 pkt I KPK).

Po szóste, trudno określić częstotliwość używania klauzul generalnych przez prawodawców kościelnych. Nie można zastosować metody porównawczo-statystycznej, nie sposób bowiem zestawiać tak różniących się pod względem objętości aktów normatywnych systemów prawnych - polskiego i kanonicznego czy innych.

Po siódme, klauzule generalne zawarte w prawie kościołów i innych związków wyznaniowych zasadniczo z jednej strony nie stwarzają tak dużego luzu decyzyjnego, jak te zawarte w prawie polskim. Cel prawa tych wspólnot jest

I38 Tekst jedn. Dz.U. z 2015 r. poz. 2164. z późn. zm.

I39 Por. M. Stahl, Zasady postępowania przed sądami administracyjnymi, [w:] Państwo $w$ stużbie obywateli. Księga Jubileuszowa Jerzego Światkiewicza, red. R. Hauser, L. Nawacki, Warszawa 2005, s. 217. 
bowiem określony przez zasady doktrynalne. To z kolei powoduje, że znaczenie klauzuli generalnej musi się mieścić w optyce nauczania doktrynalnego danego związku wyznaniowego. Jednak z drugiej strony, trudno w przypadku kościołów i innych związków wyznaniowych mówić o jakiejś tradycji prawno-doktrynalnej, sądowej czy urzędniczej dotyczącej przypisywania znaczenia klauzulom. Jedynie Kościół katolicki jest wyjątkiem od tej reguły. Oznacza to, że w praktyce dokonujący wykładni nie są związani decyzjami swoich poprzedników na urzędzie.

\subsection{Wskazówki praktyczne dla organów władzy publicznej}

W tym punkcie zostają sformułowane wskazówki metodologiczno-techniczne dla organów władzy publicznej, które w swojej pracy muszą dokonywać wykładni endogenicznego prawa kościołów i innych związków wyznaniowych. Zostaną one wyrażone w postaci zdań nakazujących. Zakres tych wskazówek jest szeroki i obejmuje zagadnienia od problemów ogólnych, czyli zasad generalnego podejścia do prawa wewnętrznego związków wyznaniowych, aż po zagadnienia szczegółowe, które tworzą modelowe podejście interpretatorów zewnętrznych do klauzul generalnych występujących w ich prawie religijnym.

\subsubsection{Zasady odnoszące się do prawa związków wyznaniowych}

I. Należy pamiętać o zasadzie wolności religijnej, która realizuje się przez autonomię i niezależność kościołów i innych związków wyznaniowych na wszystkich etapach postępowania $\mathrm{z}$ ich własnym prawem.

2. Trzeba być świadomym, że elementem autonomii i niezależności kościołów i innych związków wyznaniowych jest prawo tych podmiotów do stanowienia endogenicznych regulacji wewnętrznych.

3. Wypada uwzględnić specyfikę danego kościoła lub innego związku wyznaniowego wyrażającą się w tradycji religijnej, z której on się wywodzi, w jego zasadach dogmatyczno-moralnych oraz w liczebności jego członków.

4. Należy traktować prawo endogeniczne kościołów i innych związków wyznaniowych jako prawdziwe prawo, czyli regulacje ustanowione przez 
kompetentne podmioty, mające charakter wiążący dla swoich adresatów poprzez stwarzanie dla nich sytuacji right and duty.

5. Koniecznie trzeba traktować prawo endogeniczne kościołów i innych związków wyznaniowych jako prawo obce, czyli odmienne od prawa państwowego.

6. Zaleca się szczególną ostrożność w pracy z prawem związków wyznaniowych.

7. Należy być gotowym do częściowego przynajmniej odejścia od znanego i praktykowanego przez przedstawicieli polskiej doktryny prawniczej sposobu postępowania z tekstem prawnym.

8. Trzeba uwzględnić specyfikę prawa endogenicznego kościołów i innych związków wyznaniowych na wszystkich etapach pracy z nim. Dotyczy to szczególnie wykładni tego prawa.

9. Koniecznie trzeba dokonywać wykładni prawa endogenicznego kościołów i innych związków zgodnie z duchem, zasadami lub normami wykładni specyficznymi dla tego prawa, o ile takie istnieją, albo zgodnie z powszechnie przyjętymi w polskiej nauce prawa zasadami wykładni.

Io. Wypada konfrontować wynik wykładni z zasadami doktrynalno-moralnymi kościoła lub innego związku wyznaniowego. Każda bowiem norma prawna zawarta w systemie zrzeszenia religijnego musi być koherentna z jego system doktrynalno-moralnym.

\subsubsection{Zasady odnoszące się do klauzul generalnych w prawie związków wyznaniowych}

I. Należy pamiętać, że według przyjętych założeń systemu prawnego danego kościoła lub związku wyznaniowego rola klauzul może być albo akcentowana albo ulegać marginalizacji.

2. Należy pamiętać, że co do zasady klauzule generalne zawarte w prawie związków wyznaniowych nie stwarzają tak dużego luzu decyzyjnego, jak klauzule w prawie polskim.

3. Należy pamiętać, że funkcje klauzul generalnych w prawie kościołów i innych związków wyznaniowych mogą być odmienne od funkcji tychże zwrotów w prawie polskim.

4. Należy pamiętać, że znaczenie klauzul generalnych w prawie kościołów i innych związków wyznaniowych może być odmienne od znaczenia klauzul generalnych w prawie polskim. 
5. Znaczeń klauzul generalnych trzeba szukać, uwzględniając doktrynę kościoła lub związku wyznaniowego, posługując się jego fundamentalnymi dokumentami.

6. Należy pamiętać, że desygnaty klauzul generalnych ustalane in casu w procesie stosowania prawa muszą być koherentne z zasadami dogmatyczno-moralnymi kościoła lub związku wyznaniowego.

7. Należy uwzględnić to, że identycznie lub podobnie brzmiąca klauzula generalna może mieć różne zakresy w przepisach kościoła lub innego związku wyznaniowego i państwa.

8. Nie wolno przenosić znaczenia klauzuli generalnej z prawa jednego kościoła lub innego związku wyznaniowego na inny.

9. Należy pamiętać, że ta sama klauzula generalna występująca w obrębie tego samego religijnego systemu prawnego w różnych kontekstach może mieć odmienne znaczenie.

Io. Nie wolno przenosić bezkrytycznie znaczenia klauzuli generalnej z jednego przypadku prawnego na inny. 


\section{Zakończenie}

W publikacji podjęto zagadnienie klauzul generalnych w perspektywie prawa wewnętrznego kościołów i innych związków wyznaniowych istniejących w Polsce. Zamierzeniem było opisanie tych zwrotów z wykorzystaniem osiągnięć polskiej doktryny prawniczej na tle prawa polskiego, w celu jaśniejszego ukazania specyfiki prawa związków wyznaniowych prawnikom obeznanym głównie z prawem świeckim.

Wnioski płynące z niniejszego studium można ująć w kilku punktach:

I. Nie da się stworzyć wspólnego systemu klauzul generalnych, gwarantującego jasność, pewność oraz poprawność terminologiczną dla wszystkich, ogólnie mówiąc, endogenicznych ustaw badanych związków wyznaniowych. Przy dokonywaniu wykładni niezbędne jest rozróżnianie znaczeń klauzul generalnych w zależności od źródła ich pochodzenia. Pojemność treściowa tych zwrotów zależy od doktryny kościoła czy innego związku wyznaniowego.

2. Klauzule generalne w prawie kościołów i innych związków wyznaniowych odsyłają do wartości i ocen charakterystycznych dla danego związku wyznaniowego. Jest to podstawa, dzięki której stanowiący prawo na gruncie tych religijnych zrzeszeń może wypełnić doktrynalne założenie o swej racjonalności, która na tle koncepcji dotyczącej racjonalności prawodawcy w ujęciu polskiej doktryny prawniczej jest specyficzna.

3. Podobieństwa formalne czy funkcyjne klauzul generalnych występujące pomiędzy prawem związków wyznaniowych a prawem polskim nie oznaczają podobieństwa treściowego tych zwrotów. Nie można jednak istnienia takiego podobieństwa z góry wykluczyć. Szczególnie, że niektóre kościoły i inne związki wyznaniowe, tworząc swoją kulturę prawną, czerpią z polskiej kultury prawnej i polskiej jurysprudencji.

4. Dogłębne zbadanie praktyki stosowania prawa przez kościoły i inne związki wyznaniowe było niemożliwe z różnych względów. Po pierwsze, związki wyznaniowe nie udostępniają na zewnątrz danych potrzebnych do takiej analizy. Po drugie, „życie prawa” związków wyznaniowych jest w przypadku 
niektórych z nich bardzo ograniczone pod względem zakresu wewnętrznych regulacji i sytuacji ich stosowania. Niektóre z badanych związków wyznaniowych nie opierają swojej działalności na prawie. Ten wymiar ich istnienia i funkcjonowania jest więc minimalny. W rezultacie nie ma niezbędnych danych.

5. Niniejsze studium może mieć praktyczne znaczenie dla organów władzy publicznej, zawiera bowiem jasne wskazówki dotyczące postępowania z tekstem prawnym powstałym wewnątrz wspólnoty religijnej.

6. Należy odnotować, że istnieje, choć niekiedy w stopniu znikomym, pewne podobieństwo pomiędzy aksjologiami, do których odwołują się klauzule generalne z aktów normatywnych kościołów i innych związków wyznaniowych. W tych podobieństwach można upatrywać elementów ekumenicznych czy dialogicznych łączących te związki.

Na koniec można jeszcze wysunąć wobec niektórych kościołów lub innych związków wyznaniowych sugestię, aby bardziej dbały o prawne elementy swojej działalności. Chodzi tu głównie o jakość stanowionego endogenicznie prawa. Jeżeli nawet zrzeszenia te nie chcą tego czynić z uwagi na własne poglądy dotyczące prawa (czy też szczególnie prawa stanowionego), to powinny mieć na uwadze organy władzy publicznej. Dla tych organów tekst normatywny jest podstawą ułożenia relacji ze związkami wyznaniowymi, a szczególnie podejmowania konkretnych decyzji dotyczących tych związków. Jest to, co należy podkreślić, sugestia, a nie postulat. Nie można bowiem domagać się, a tym bardziej narzucać związkom wyznaniowym stosunku do prawa, czy też domagać się recepcji elementów polskiej kultury prawnej. Wolność religijna chroni niezależność i autonomię kościołów i innych związków także w tym zakresie. 


\section{Bibliografia}

1. Akty normatywne i dokumenty doktrynalne kościołów i innych związków wyznaniowych ${ }^{140}$

Bonifatio Pp. VIII, De regulis iuris, 3.03.I298, [w:] Corpus Iuris Canonici, editio Lipsiensi secunda post Ae. L. Richteri curas ad librorum manuscriptorum et editionis romanae fidem recognovit et adnotatione critica instruxit Ae. Friedberg, vol. 2, Gratz 1959, kol. II22-II24.

Bonifatio pp. viII, Liber sextus decretalium, 3.03.I298, [w:] Corpus Iuris Canonici, editio Lipsiensi secunda post Ae. L. Richteri curas ad librorum manuscriptorum et editionis romanae fidem recognovit et adnotatione critica instruxit Ae. Friedberg, vol. 2, Gratz 1959, kol. 933-II2I.

Codex Canonum Ecclesiarum Orientalium auctoritate Ioannis Pauli PP. II promulgatus, I8.IO.I990, AAS 82 (1990), s. I045-I353; tekst łacińsko-polski: Codex Canonum Ecclesiarum Orientalium auctoritate Ioannis Pauli PP. II promulgatus, Kodeks kanonów Kościołów wschodnich. Promulgowany przez papieża Jana Pawła II, wydanie łacińsko-polskie, Lublin 2002.

Codex Iuris Canonici auctoritate Ioannis Pauli PP. II promulgatus, 25.0I.1983, AAS 75 (1983), pars 2, s. I-30I; tekst łacińsko-polski: Kodeks prawa kanonicznego, przekład zatwierdzony przez Konferencję Episkopatu Polski, Poznań 1984. Congregatio pro Doctrina Fidei, Declaratio Dominus Iesus de Iesu Christi atque Ecclesiae unicitate et universalitate salvifica, 6.08.2000, AAS 92 (2000), s. $742-765$.

Congregatio pro Dotrina Fidei, Nota doctrinalis de christifidelium rationibus in publicis negotiis gerendis, 24.II.2002, AAS 96 (2004), s. 359-370; tekst polski: Kongregacja Nauki Wiary, Nota doktrynalna o niektórych aspektach dziatalności i postępowania katolików w życiu politycznym, „L'Osservatore Romano", wyd. polskie, 2 (2003), s. 49-54.

I40 Statuty kościołów i innych związków wyznaniowych opublikowane w publikatorach państwowych stanowią część porządku państwowego i jednocześnie danego religijnego zrzeszenia. W Bibliografii są one umieszczone tylko raz - w części pierwszej. 
Congregatio de Propaganda Fide, Instructio super dispensationibus matrimonialibus, Ass I9 (I877), s. 29I-295.

Constitution of the Lutheran World Federation, (as adopted by the LWF Eighth Assembly, Curitiba, Brazil, 1990, including amendments adopted by the LWF Ninth Assembly, Hong Kong, 1997 and by the LWF Eleventh Assembly, Stuttgart, 20IO), https://www.lutheranworld.org/sites/default/files/Constitution\%20EN\%20final_o.pdf (25.07.2015).

Decretum magistri Gratiani, II4O r., [w:] Corpus Iuris Canonici, editio Lipsiensi secunda post Ae. L. Richteri curas ad librorum manuscriptorum et editionis romanae fidem recognovit et adnotatione critica instruxit Ae. Friedberg, vol. I, Gratz 1959, kol. I-I424.

Dekret z dnia I kwietnia 2015 r., nr 724/20I5 oraz całość dokumentacji, Archiwum Kurii Metropolitalnej w Krakowie.

Dekret z dnia Io kwietnia 20I5 r., nr 780/20I5 oraz całość dokumentacji, Archiwum Kurii Metropolitalnej w Krakowie.

Dekret z dnia I2 stycznia 20I5 r., nr 39/20I5 oraz całość dokumentacji, Archiwum Kurii Metropolitalnej w Krakowie.

Dekret z dnia I3 maja 20I0, nr I306/20Io oraz całość dokumentacji, Archiwum Kurii Metropolitalnej w Krakowie.

Dekret z dnia I5 maja 20I5 r., nr II53/20I5 oraz całość dokumentacji, Archiwum Kurii Metropolitalnej w Krakowie.

Dekret z dnia I5 maja 2015 r., nr II86/20I5 oraz całość dokumentacji, Archiwum Kurii Metropolitalnej w Krakowie.

Dekret z dnia I8 marca 2015 r., nr 548/20I5 oraz całość dokumentacji, Archiwum Kurii Metropolitalnej w Krakowie.

Dekret z dnia 23 stycznia 2015 r., nr I3I/20I5 oraz całość dokumentacji, Archiwum Kurii Metropolitalnej w Krakowie.

Dekret z dnia 26 listopada 2009 r., nr 3363/2009 oraz całość dokumentacji, Archiwum Kurii Metropolitalnej w Krakowie.

Dekret z dnia 3 lipca 2008 r., nr I8oI/2008 oraz całość dokumentacji, Archiwum Kurii Metropolitalnej w Krakowie.

Dekret z dnia 5 stycznia 2015 r., nr 6/20I5 oraz całość dokumentacji, Archiwum Kurii Metropolitalnej w Krakowie.

Dekret z dnia 6 lipca 20II r., nr I928/20II oraz całość dokumentacji, Archiwum Kurii Metropolitalnej w Krakowie.

Dekret z dnia 7 kwietnia 2015 r., nr 748/20I5 oraz całość dokumentacji, Archiwum Kurii Metropolitalnej w Krakowie. 
Formuta zgody, przeł. J. Pośpiech, [w:] Ksiegi wyznaniowe Kościota luterańskiego, Bielsko-Biała 20II, s. 387-528.

Jan Paweł II, Migracje a dialog międzyreligijny (Orędzie Ojca Świętego na światowy Dzień Migranta 2002 r.), „L'Osservatore Romano” 4 (2002), s. 5.

Joannes Paulus PP. II, Adhortatio apostolica Familiaris consortio de Familiae

Christianae muneribus in mundo huius temporis, 22.II.I98I, AAS 74 (I982), s. 8I-I9I; tekst polski: Jan Paweł II, Adhortacja apostolska Familiaris consortio, Wrocław 1994.

Joannes Paulus PP. II, Adhortatio apostolica Christifideles laici de vocatione et missione Laicorum in Ecclesia et in mundo, 30.I2.I988, AAS 8I (1989), s. 393-52I; tekst polski: Jan Paweł II, Posynodalna adhortacja apostolska „Christifideles laici" Ojca Świętego Jana Pawta II o powotaniu i misji świeckich w Kościele i w świecie dwadzieścia lat po Soborze Watykańskim II, Wrocław 1999.

Joannes Paulus Pp. II, Allocutio Ho desiderato a Summo Pontifice in aula supra porticum Vaticanae basilicae habita, ad novum Codicem Iuris Canonici, paucis ante diebus promulgatum, publice exhibendum, 3.02.1983, AAS 75 (1983), pars I, s. 455-463.

Joannes Paulus PP. II, Constitutio apostolica Fidei depositum qua Catholicae Ecclesiae catechismus post Concilium Oecumenicum Vaticanum II instauratus publici iuris fit, II.IO.I992, AAS 86 (I994), s. II3-II8.

Joannes Paulus PP. II, Constitutio apostolica Pastor bonus de Romana Curia, 28.06.1988, AAS 8 o (1988), s. 84I-930; tekst polski: Jan Paweł II, Konstytucja apostolska Pastor bonus o Kurii Rzymskiej, przeł. P. Majer, [w:] Kodeks Prawa Kanonicznego. Komentarz, red. P. Majer, wyd. pol. na podst. wyd. hiszp., Kraków 20II, s. 1397-I465.

Joannes Paulus Pp. II, Constitutio apostolica Sacri canones Codex Canonum Ecclesiarum Orientalium promulgatur, I8.IO.I990, AAS 82 (1990), s. IO33-IO44; tekst polski: Codex Canonum Ecclesiarum Orientalium auctoritate Ioannis Pauli PP. II promulgatus, Kodeks kanonów Kościotów wschodnich. Promulgowany przez papieża Jana Pawła II, wydanie łacińsko-polskie, Lublin 2002, s. 28-4I. Joannes Paulus PP. II, Litterae apostolicae motu proprio Recognitio Iuris Canonici Pontificia Commissio Codici Iuris Canonici authentice interpretando constituitur, 2.OI.1984, AAs 76 (1984), s. 433-434.

Joannes Paulus PP. II, Litterae enyclicae Centesimus annus, I.05.I99I, AAS 83 (1991), s. 793-867; tekst polski: Jan Paweł II, Centesimus annus: encyklika w setna rocznice Encykliki Rerum novarum, Warszawa I99I.

Katechizm Kościota Katolickiego, Poznań 1994. 
Konferencja Episkopatu Polski, Instrukcja o kanonicznym badaniu narzeczonych przed ślubem z dnia 9 września 1946 r., Olsztyn 1947.

Konferencja Episkopatu Polski, Instrukcja o przygotowaniu do zawarcia małżeństwa w Kościele katolickim z dnia 5 września 1986 r., „Akta Konferencji Episkopatu Polski” I (1998) nr I, s. 85-I37.

Konfesja, czyli wyznanie wiary i ustrój zborów baptystów, Ostrzeszów 1930 (wersja uwspółcześniona wydana pod tytułem: Wyznanie wiary baptystów polskich z I930 r., Warszawa 2000).

Kozłowska F., Dzieto Wielkiego Mitosierdzia, Płock 2002.

Ksiegga konstytucji i zarządzeń Braci Zakonu Kaznodziejów, w tłumaczeniu na język polski, wyd. 6, Warszawa 2003.

Księgi wyznaniowe Kościoła luterańskiego, Bielsko-Biała 2011.

Ku królestwu Bożemu, Felicjanów 2009.

Luter M., Artykuty szmalkaldzkie, przeł. W. Niemczyk, [w:] Księgi wyznaniowe Kościota luterańskiego, Bielsko-Biała 20II, s. 335-358.

Luter M., Duży katechizm, przeł. A. Wantuła, [w:] Ksiegi wyznaniowe Kościota luterańskiego, Bielsko-Biała 20II, s. 57-I3I.

Luter M., Maty katechizm, przeł. A. Wantuła, [w:] Ksiegi wyznaniowe Kościota luterańskiego, Bielsko-Biała 20II, s. 4I-55.

Luter M., O świeckiej zwierzchności, w jakiej mierze należy być jej postusznym, przeł. M Hintz, [w:] M. Luter, Pisma etyczne, red. M. Hintz, Bielsko-Biała 2009, s. 179-215.

Malicki A., List z dnia 9.IO.20I5 r. (archiwum prywatne autora, sygn. KEM/I).

Melanchton F., Obrona Wyznania augsburskiego, przeł. J. W. Jackowski, [w:] Księgi wyznaniowe Kościota luterańskiego, Bielsko-Biała 20II, s. 165-325.

Melanchton F., Wyznanie augsburskie, przel. J. W. Jackowski, [w:] Księgi wyznaniowe Kościota luterańskiego, Bielsko-Biała 20II, s. I43-I63.

Paulus vI PP., Constitutio apostolica Indulgentiarum doctrina Sacrarum Indulgentiarum recognitio promulgatur, I.OI.1967, AAS 59 (I967), s. 5-24.

Pilecki S., List z dnia I4.IO.20I5 r. (archiwum prywatne autora, sygn. KzR/I).

Pismo Święte Starego i Nowego Testamentu w przekładzie z języków oryginalnych, opracował zespół biblistów polskich z inicjatywy benedyktynów tynieckich, Poznań-Warszawa 1983.

Pius XII PP., Constitutio Apostolica Christus Dominus de disciplina servanda quoad ieiunium Eucharisticum, 6.OI.1953, AAS 45 (1953), s. I5-24.

Pius XII Pp., Litterae encyclicae Mystici Corporis Christi, quod est Ecclesia, 29.06.1943, AAS 35 (1943), s. 193-248; tekst polski: Pius XII, Mistici Corporis 
Christi: Encyklika Ojca św. Piusa XII o Mistycznym Ciele Chrystusa, Kraków I944.

Pius PP. XI, Motu proprio Litterarum latinarum in athenaeo gregoriano constituenda, 20.IO. 1924, AAS I6 (I924), s. 4I7-420.

Pontificia Commissio Codici Iuris Canonici Authentice Interpretando, Responsiones ad proposita dubia ad can. I737 $\$$ I, AAS 8 O (I988), s. I8I8.

Pontificia Commissio Codici Iuris Canonici Authentice Interpretando, Responsiones ad proposita dubia ad can. I263, AAs 8I (1989), s. 991.

Pontificia Commissio Codici Iuris Canonici Authentice Interpretando, Responsiones ad proposita dubia ad can. $402 \$$ I, AAS 83 (I99I), s. 1093.

Pontificium Consilium de Legum Textibus, Istruzione Dignitas connubii sulle norme da osservarsi nei tribunali ecclesiastici nelle cause matrimoniali, 25.0I.2005, Città del Vaticano 2005; polskie tłumaczenie [w:] Komentarz do Instrukcji procesowej „Dignitas connubii”, red. T. Rozkrut, Sandomierz 2007.

Pragmatyka Służbowa Kościoła Ewangelicko-Augsburskiego w Rzeczypospolitej Polskiej z dnia 28 listopada 1999 r. z późniejszymi zmianami (tekst jednolity z dnia II kwietnia 20I5 r.), http://www.bik.luteranie.pl/files/Prawo/20I5-04-IIPragmatykaSubowav.pp.pdf (20.01.2016).

Prawo Wewnętrzne Kościoła Ewangelicko-Metodystycznego w Rzeczypospolitej Polskiej z dnia 25 maja I99I r. z późn. zm., [w:] Mniejszości wyznaniowe $w$ Polsce. Prawo wewnętrzne (statutowe), wprowadzenie, zbiór statutów, opracowanie R. Brożyniak, M. Winiarczyk-Kossakowska, Warszawa 20I4, s. $43-56$.

Prawo Wewnętrzne Kościoła Ewangelicko-Reformowanego w Rzeczypospolitej Polskiej - weszło w życie dnia I stycznia 2015 r., http://www.reformowani. $\mathrm{pl} /$ index.php/czytelnia/26-prawo-wewnetrznekosciola-ewangelicko-reformowanegow-rzeczypospolitej-polskiej (Io.03.2016).

Prawo Wewnętrzne Kościoła Polskokatolickiego w Rzeczypospolitej Polskiej z dnia 27 czerwca I995 r. z późn. zm. (tekst jednolity z dnia Io grudnia 2008 r.), [w:] Mniejszości wyznaniowe w Polsce. Prawo wewnętrzne (statutowe), wprowadzenie, zbiór statutów, opracowanie R. Brożyniak, M. Winiarczyk-Kossakowska, Warszawa 20I4, s. 98-II8.

Prawo Wewnętrzne Kościoła Zielonoświątkowego w Rzeczypospolitej Polskiej uchwalone przez Synod Nadzwyczajny dnia 28 września 2007 r. z późn. zm. (tekst jednolity z dnia 25 września 2015 r.), http://kz.pl/kzw/wp-content/ uploads/2009/og/Prawo-Wewnętrzne-KZ-20I5.pdf (I0.03.2016). 
Prawo wewnętrzne nierzymskokatolickich zwiąków wyznaniowych w Polsce. Wybór aktów prawnych, oprac. P. Borecki, C. Janik, Warszawa 2012.

Prawo wewnętrzne wyznaniowej wspólnoty żydowskiej w Rzeczypospolitej Polskiej z dnia Is stycznia 2006 r., [w:] Mniejszości wyznaniowe w Polsce. Prawo wewnętrzne (statutowe), wprowadzenie, zbiór statutów, opracowanie R. Brożyniak, M. Winiarczyk-Kossakowska, Warszawa 20I4, s. I35-I44.

Prawo zborowe Kościota Adwentystów Dnia Siódmego, przeł. Ł. Romanowski, red. M. Rakowski, A. Siciński, Warszawa 2013.

Przepisy dyscyplinarne Kościoła Ewangelicko-Augsburskiego w RP z dnia I8 października 2010 r. (tekst ujednolicony przyjęty uchwałą Rady Synodalnej I5/20I5 z I3 listopada 20I5 r.), http://www.bik.luteranie.pl/files/Prawo/20I5II-I3PrzepisyDyscyplinarneujednoliconyrs.pdf (20.0I.20I6).

Regulamin Diecezjalny Kościoła Ewangelicko-Augsburskiego w Rzeczpospolitej Polskiej z dnia I8 lutego $2000 \mathrm{r}$. z późniejszymi zmianami (tekst jednolity z dnia I3 marca 20I5 r.), http://www.bik.luteranie.pl/files/Prawo/20I50313RegulaminDiecezjalny.pdf (I2.03.2016).

Regulamin Krajowej Konferencji Kościoła Chrześcijan Baptystów w Rzeczypospolitej Polskiej z dnia I października 2005 r. (tekst jednolity z dnia I7 maja 2013 r.), http://www.baptysci.pl/akty-prawne/I807-regulamin-krajowej-konferencji-kosciola-chrzescijan-baptystow-w-rzeczypospolitej-polskiej (I2.02.20I6).

Regulamin Obrad Synodu Kościoła Ewangelicko-Augsburskiego w RP uchwalony podczas 6. Sesji xir Synodu w Warszawie w dniach i6-I8.Io. 2009 r. http://www.bik.luteranie.pl/files/Prawo/ros.pdf (20.0I.2016).

Regulamin Parafialny - przyjęty na 2. Sesji Synodu Kościoła w dniach 26-28 października 2007 z późniejszymi zmianami (tekst jednolity z 24 czerwca 20I5 r.) http://www.bik.luteranie.pl/files/Prawo/20I5-o6-24RegulaminParafialnytekstjednolityвıк.pdf (20.0I.20I6).

Regulamin Rzecznika Dyscyplinarnego z dnia 27 maja 2013 r., http://www.bik. luteranie.pl/files/Rada\%2oSynodalna/RegulaminRzecznikaDyscyplinarnegotekstobow.pdf (20.0I.20I6).

Regulamin Synodu Kościoła Zielonoświątkowego w RP z dnia 25 września 2015 r. (archiwum prywatne autora, sygn. Kz/2).

Regulamin Władz Zwierzchniczych z dnia 26 października 1996 r. z późniejszymi zmianami (tekst jednolity z dnia I6 grudnia 20II r., http://www.bik.luteranie.pl/files/Prawo/RZWKTekstJednolityıosesjaxissynodu.pdf (20.0I.20I6).

Regulamin Wyborów Biskupa Diecezjalnego - bez daty uchwalenia, wszedł w życie z dniem I lutego 1997 r. z późniejszymi zmianami (tekst jednolity 
z dnia 2 czerwca 2010 r.), http://www.bik.luteranie.pl/files/Prawo/20Io06-o2Regulamin WyborwBiskupaDiecezjalnegozezmianamizzo62oıo-I.doc (20.01.2016).

Sacrosanctum Concilium Oecumenicum Vaticanum II, Constitutio dogmatica $\mathrm{Lu}$ men gentium de Ecclesia, 2I.II.I964, AAS 57 (1965), s. 5-75; tekst łacińsko-polski: Sobór Watykański II, Konstytucja dogmatyczna o Kościele Lumen gentium, [w:] Sobór Watykański II, Konstytucje, dekrety, deklaracje, Poznań 2008, s. I44-263.

Sacrosanctum Concilium Oecumenicum Vaticanum II, Constitutio pastoralis Gaudium et spes de Ecclesia in mundo huius temporis, 7.I2.1965, AAS 58 (I966), s. IO25-III5; tekst łacińsko-polski: Sobór Watykański II, Konsytucja duszpasterska o Kościele w świecie współczesnym Gaudium et spes [w:] Sobór Watykański II, Konstytucje, dekrety, deklaracje, Poznań 2008, s. 824-98I. Sacrosanctum Concilium Oecumenicum Vaticanum II, Declaratio Dignitatis humanae de libertate religiosa, 7.I2.I965, AAS 58 (1966), s. 929-946; tekst łacińsko-polski: Sobór Watykański II, Deklaracja o wolności religijnej Dignitatis humanae, [w:] Sobór Watykański II, Konstytucje, dekrety, deklaracje, Poznań 2008, s. 638-66I.

Sacrosanctum Concilium Oecumenicum Vaticanum II, Decretum Nostra aetate de Ecclesiae habitudine ad religiones non-Christianas, 29.IO.I965, AAS 58 (I966), s. 740-744; tekst łacińsko-polski: Sobór Watykański II, Deklaracja o stosunku Kościoła do religii niechrześcijańskich Nostra aetate, [w:] Sobór Watykański II, Konstytucje, dekrety, deklaracje, Poznań 2008, s. 520-527.

Sacrosanctum Concilium Oecumenicum Vaticanum II, Decretum Unitatis redintegratio de oecumenismo, 2I.II.I964, AAS 57 (1965), s. 90-II2; tekst łacińsko-polski: Sobór Watykański II, Dekret o ekumenizmie Unitatis redintegratio, [w:] Sobór Watykański II, Konstytucje, dekrety, deklaracje, Poznań 2008, s. 302-333.

Schulchan Aruch, tłumaczenie na język angielski - ShulchanArach.com: Free English Translation of The Shulchan Aruch: Jewish Code of Law, http://www. shulchanarach.com (I8.09.20I5).

Secretaria Status, Normae de Latino textu Codicis luris Canonici tuendo eodemque alias in linguas convertendo, 28.0I.1983, „Communicationes” I5 (1983), s. 4I.

Statut Karaimskiego Związku Religijnego w Rzeczypospolitej Polskiej z dnia 26 sierpnia 1936 r., który stanowi załącznik do rozporządzenia Rady Ministrów dnia 26 sierpnia 1936 r. o uznaniu Statutu Karaimskiego Związku Religijnego w Rzeczypospolitej Polskiej (Dz.U. Nr 72, poz. 5I8). 
Statut Karaimskiego Związku Religijnego z dnia I8 marca 1973 r.; wersja znowelizowana w dniu 8 października $20 I$ r. przesłana przez S. Pileckiego (Przewodniczącego Zarządu Karaimskiego Związku Religijnego) w liście dnia I4.IO.20I5 r. (archiwum prywatne autora, sygn. KZR/2).

Statut Kościoła Adwentystów Dnia Siódmego w Rzeczypospolitej Polskiej z dnia I2 czerwca 2008 r. zmieniony uchwałami xxı Zjazdu Kościoła nr Io i II z dnia 30 maja 2013 r. oraz nr I3, I4, I5, I6, I7, I8, I9 i 20 z dnia 3I maja 2013 r. (tekst jednolity z dnia 3I maja 2013 r.) http://www.adwent.pl/component/attachments/download/396 (IO.IO.2015).

Statut Kościoła Katolickiego Mariawitów w Rzeczypospolitej Polskiej z dnia I4 maja 1967 r. (zredagowany dnia 2 stycznia I968 r.), [w:] Mniejszości wyznaniowe w Polsce. Prawo wewnętrzne (statutowe), wprowadzenie, zbiór statutów, opracowanie R. Brożyniak, M. Winiarczyk-Kossakowska, Warszawa 20I4, s. 65-7I. Statut Kościoła Starokatolickiego Mariawitów z dnia 26 kwietnia 1967 r., [w:] Mniejszości wyznaniowe w Polsce. Prawo wewnętrzne (statutowe), wprowadzenie, zbiór statutów, opracowanie R. Brożyniak, M. Winiarczyk-Kossakowska, Warszawa 20I4, s. 57-64.

Statut Muzułmańskiego Związku Religijnego w Rzeczypospolitej Polskiej z dnia 28 lutego 2009 r. z późn. zm., http://www.mzr.pl/pl/pliki/statut-20I4-0315. pdf (II.IO.20I6).

Statut Muzułmańskiego Związku Religijnego w Rzeczypospolitej Polskiej z dnia 26 sierpnia 1936 r., który stanowi załącznik do rozporządzenia Rady Ministrów z dnia 26 sierpnia 1936 r. o uznaniu Statutu Muzułmańskiego Związku Religijnego w Rzeczypospolitej Polskiej (Dz.U. poz. 517).

Statut Wewnętrzny Polskiego Autokefalicznego Kościoła Prawosławnego z dnia Io lutego 1995 r., [w:] Mniejszości wyznaniowe w Polsce. Prawo wewnętrzne (statutowe), wprowadzenie, zbiór statutów, opracowanie R. Brożyniak, M. Winiarczyk-Kossakowska, Warszawa 20I4, s. I5-2I.

Statut Wschodniego Kościoła Staroobrzędowego nieposiadającego hierarchii duchowej z dnia 25 marca 1984 r. z późn. zm., [w:] Mniejszości wyznaniowe $w$ Polsce. Prawo wewnętrzne (statutowe), wprowadzenie, zbiór statutów, opracowanie R. Brożyniak, M. Winiarczyk-Kossakowska, Warszawa 20I4, s. I5-2I. Statut Wschodniego Kościoła Staroobrzędowego, nie posiadającego hierarchji duchownej z dnia z dnia 22 marca 1928 r., który stanowi załącznik do rozporządzenia Rady Ministrów z dnia 22 marca 1928 r. o uznaniu statutu Wschodniego Kościoła Staroobrzędowego, nie posiadającego hierarchji duchownej (M.P. Nr 2IO). 
Statut Związku Maryawitów Nieustającej Adoracyi Ubłagania, [w:] Dzieto Wielkiego Mitosierdzia dla świata czyli Wypetnienie się objawienia św. Jana Apostoła na staro-katolickim kościele maryawitów, Płock 1922, s. 317-320.

Suprema Congregatio Sanctae Romanae et Universalis Inquisitionis, Decretum Mariavitarum sacerdotum quo choriphaei sectae Mariaviticae plectuntur excommunicatione maiori, nominali et personali, 5.I2.1906, AAS 40 (1907), 69-70; polska wersja dekretu: S. Rybak, Mariawityzm. Dzieje i wspótczesność, Warszawa 20II, s. 5I-52.

Święty Koran. Tekst arabski i ttumaczenie polskie, tłumaczenie oparte na przekładzie Malik, Ghulam, Farid, Tilford 1996.

Szuigowicz D., List z dnia I0.09.20I5 r. (archiwum prywatne autora, sygn. KEM/I). The Babylonian Talmud, ed. Rabbi Dr. Isidore Epstein, London 1952, wersja online: http://www.come-and-hear.com/talmud/index.html (I8.09.2015).

The Book of Discipline of the United Methodist Church 2012, Nashville 2013, we fragmentach jako Ksiega Dyscypliny Zjednoczonego Metodystycznego Kościota, „Methodos. Przegląd Teologiczno-Społeczny Wyższego Seminarium Teologicznego im. Jana Łaskiego Kościoła Ewangelicko-Metodystycznego W RP" 5-8 (2006-2009), s. 9-I54.

Tora Pardes Lauder, Ksiega Pierwsza. Bereszit, red. S. Pecaric, przeł. E. Gordon, Kraków 200I.

Ustawy Zgromadzenia Kapłanów Maryawitów Nieustającej Adoracyi Ubłagania, [w:] Dzieto Wielkiego Mitosierdzia dla świata czyli Wypetnienie się objawienia św. Jana Apostoła na staro-katolickim kościele maryawitów, Płock I922, s. 32I-338.

Ustawy Zgromadzenia Sióstr Maryawitek Nieustającej Adoracyi Ubłagania, [w:] Dzieto Wielkiego Mitosierdzia dla świata czyli Wypetnienie się objawienia św. Jana Apostota na staro-katolickim kościele maryawitów, Płock 1922, s. 339-373.

Wyktadnie autentyczne przepisów prawa kościelnego http://bik.luteranie.pl/files/ Prawo/wykladnie.pdf (I2.0I.20I6).

Wywiad z biskupem M. L. Jabłońskim (archiwum prywatne autora, sygn. skM/I). Wyznanie wiary oraz Zasady ogólne. Tekst jednolity przyjęty uchwałą Rady Synodalnej nr 3/20I4 z I7 lutego $2014 \mathrm{r}$.

Zasadnicze Prawo Wewnętrzne Kościoła Chrześcijan Baptystów w Rzeczypospolitej Polskiej z dnia I października 2005 r. (tekst jednolity z dnia I8 maja $20 I 4$ r.), http://www.baptysci.pl/akty-prawne/945-zasadnicze-prawo-wewnetrzne?start=I (I0.09.2016). 
Zasadnicze Prawo Wewnętrzne Kościoła Ewangelicko-Augsburskiego w Rzeczpospolitej Polskiej z dnia 26 października 1996 r., (tekst jednolity z I lipca 2016 r.), http://bik.luteranie.pl/files/Prawo/20I6-07-orZasadniczePrawoWewntrzne.pdf (II.IO.20I6).

Zasady ogólne, http://metodysci.pl/czytelnia/artykuly-wiary/zasady-ogolne/ (II.08.20I5).

Zasady socjalne 2000-2004: nauka spoteczna Zjednoczonego Kościoła Metodystycznego, red. Z. Kamiński, red. merytoryczna E. Puślecki, Warszawa 2003.

Zasady Wiary Kościota Adwentystów Dnia Siódmego, http://www.adwent.pl/o-kosciele/zasady-wiary (I0.09.20I5).

\section{Państwowe akty normatywne i inne dokumenty}

Akt Końcowy Konferencji Bezpieczeństwa i Współpracy w Europie, Helsinki, I sierpnia I975 r., Warszawa I980.

Commission of the European Communities, European Governance: A White Paper, сом (200I) 428, 25.07.200I, „Official Journal” C 287, vol. 44, I2.IO.200I, s. I-29.

Decyzja ministra-kierownika Urzędu do Spraw Wyznań NR NK-803/29/1/84.

Deklaracja w sprawie praw osób należących do mniejszości narodowych lub etnicznych, religijnych i językowych, przyjęta przez onz jako rezolucja Zgromadzenia Ogólnego onz nr 47/I35 w dniu Io grudnia 1992 r., http:// www.hfhrpol.waw.pl/pliki/deklaracja_praw_osob_nalezacych_do_mniejszosci_narodowych_lub_etnicznych_religijnych_i_jezykowych_2.pdf (28.07.2015).

Deklaracja w sprawie wyeliminowania wszelkich form nietolerancji i dyskryminacji opartych na religii lub przekonaniach przyjęta przez onz jako rezolucja Zgromadzenia Ogólnego onZ nr 36/55 w dniu 25 listopada 198r r., http:// libr.sejm.gov.pl/tekoi/txt/onz/1981.html (28.07.2015).

Dekret Naczelnika Państwa z dnia 7 lutego I919 r. o zmianach w organizacji gmin wyznaniowych żydowskich na terenie byłego Królestwa Kongresowego („Dziennik Praw Państwa Polskiego” z I9I9 r. Nr I4, poz. I75.).

Dekret Prezydenta Rzeczypospolitej Polskiej z dnia I8 listopada 1938 r. o stosunku Państwa do Polskiego Autokefalicznego Kościoła Prawosławnego (Dz.U. Nr 88, poz. 597 z późn. zm.).

Dekret Prezydenta Rzeczypospolitej z dnia 25 listopada 1936 r. o stosunku Państwa do Kościoła Ewangelicko-Augsburskiego w Rzeczypospolitej Polskiej (Dz.U. Nr 88, poz. 6rz z późn. zm.). 
Dekret z dnia I6 października 1945 r. o stosunku Państwa do Kościoła Metodystycznego w Rzeczypospolitej Polskiej (Dz.U. Nr 46, poz. 259).

Dekret z dnia 25 września 1945 r. Przepisy wprowadzające prawo małżeńskie (Dz.U. Nr 48, poz. 27I).

Dekret z dnia 25 września 1945 r. Przepisy wprowadzające prawo o aktach stanu cywilnego (Dz.U. Nr 48, poz. 273).

Dekret z dnia 5 sierpnia 1949 r. o ochronie wolności sumienia i wyznania (Dz.U. Nr 45, poz. 334).

Dekret z dnia 5 września 1947 r. o uregulowaniu położenia prawnego Kościoła Ewangelicko-Reformowanego w Rzeczypospolitej Polskiej, Kościoła Mariawickiego i Kościoła Starokatolickiego (Dz.U. Nr 59, poz. 316 z późn. zm.). Gesetz betreffend die Erteilung der Korporationsrechte an Baptistengemeinden. Vom 7. Juli I875 (Ustawa z dnia 7 lipca I875 r. o nadaniu praw korporacyjnych gminom Baptystów) „Gesetz-Sammlung für die Königlichen Preussischen Staaten” (Zbiór praw dla Państw Królestwa Pruskiego) Berlin 1875, Nr. 27, Bon Nr. 8336, s. 374).

Gesetz betreffend die Rechte der altkatholischen Kirchengemeinschaften an dem kirchlichen Vermögen. Vom 4. Juli I875 (Ustawa z dnia 4 lipca I875 r. o prawach starokatolickich gmin kościelnych do majątku kościelnego) „Gesetz-Sammlung für die Königlichen Preußischen Staaten” (Zbiór praw dla Państw Królestwa Pruskiego) Berlin I875, Nr. 22, Bon Nr. 8329, s. 333-334). Gesetz über die Verhältnisse der Juden. Von 4. Juli 1875 (Ustawa z dnia 23 lipca I847 r. o związkach Żydów) („Gesetz-Sammlung für die Königlichen Preussischen Staaten" (Zbiór praw dla Państw Królestwa Pruskiego) Berlin I847, Nr. 30, Bon Nr. 2871, s. 263-278).

Karta Narodów Zjednoczonych, Statut Międzynarodowego Trybunału Sprawiedliwości i Porozumienie ustanawiające Komisję Przygotowawczą Narodów Zjednoczonych z dnia 26 czerwca 1945 r. (Dz.U. z 1947 r. Nr 23, poz. $90 \mathrm{z}$ późn. zm.).

Karta praw podstawowych Unii Europejskiej z dnia 7 grudnia 2000 r. (Dz.Urz. UE. C Nr 326 z 2012 r., s. 39I).

Konkordat między Stolicą Apostolską i Rzeczpospolitą Polską, podpisany Warszawie dnia 28 lipca 1993 r. (Dz.U. z 1998 r. Nr 51, poz. 318).

Konkordat pomiędzy Stolicą Apostolską a Rzecząpospolitą Polską, podpisany w Rzymie dnia io lutego 1925 r. (Dz.U. Nr 72, poz. 501 i 502 ).

Konstytucja Polskiej Rzeczypospolitej Ludowej uchwalona przez Sejm Ustawodawczy w dniu 22 lipca 1952 r. (tekst jedn. Dz.U. z 1976 r. Nr 7, poz. 36). 


\section{Bibliografia}

Konwencja (nr III) dotycząca dyskryminacji w zakresie zatrudnienia i wykonywania zawodu przyjęta w Genewie dnia 25 czerwca 1958 r. (Dz.U. z 196I r. Nr 42, poz. 218).

Konwencja o ochronie praw człowieka i podstawowych wolności sporządzona w Rzymie dnia 4 listopada 1950 r. Konwencja o ochronie praw człowieka i podstawowych wolności sporządzona w Rzymie dnia 4 listopada I950 r. zmieniona następnie Protokołami nr 3, 5 i 8 oraz uzupełniona Protokołem nr 2 (Dz.U. z I993 r. Nr 6I, poz. 284).

Konwencja o prawach dziecka przyjęta przez Zgromadzenie Ogólne Narodów Zjednoczonych dnia 20 listopada 1989 r. (Dz.U. z I99I r. Nr I20, poz. 526; tekst wraz z załącznikiem zawierającym zastrzeżenia i deklaracje strony polskiej).

Konwencja w sprawie zwalczania dyskryminacji w dziedzinie oświaty sporządzona w Paryżu dnia I5 grudnia I960 r. (Dz.U. z I964 r. Nr 40, poz. 268).

Międzynarodowy pakt praw gospodarczych, społecznych i kulturalnych otwarty do podpisu w Nowym Jorku dnia I9 grudnia 1966 r. (Dz.U. z I977 r. Nr 38, poz. I69).

Międzynarodowy pakt praw obywatelskich i politycznych otwarty do podpisu w Nowym Jorku dnia 19 grudnia 1966 r. (Dz.U. z 1977 r. Nr 38, poz. 167).

Ministerstwo Administracji i Cyfryzacji, Pismo z dnia 30.Io.20I5 r., DwRMnie-WRPiFK.0I33.I2.20I5 (archiwum prywatne autora, sygn. MAic/I).

Ministerstwo Spraw Wewnętrznych i Administracji, Pismo z dnia I5.12.20I5 r., DWRMNIE-WRPIFK.OI33.I2.2OI5 (archiwum prywatne autora, sygn. MSWiA/2).

Ministerstwo Spraw Wewnętrznych i Administracji, Pismo z dnia 17 października 2016 r., DBI- WODOUIP -0667-I-IOI/20I6 (archiwum prywatne autora, sygn. MSWiA/3).

Ministerstwo Spraw Wewnętrznych i Administracji, Tryb przygotowania i zawierania umów, o których mowa w art. 25 ust. 5. Konstytucji RP z dnia I6 października 2008 r., DWRMNiE-O230-IO/O8/MPC.

Ministerstwo Spraw Wewnętrznych i Administracji, Zasady prowadzenia negocjacji przez Wydziat Regulacji Prawnych i Funduszu Kościelnego z dnia 26 lutego 2010 r., DWRMNiE-O23O-3/IO/MPC.

Obwieszczenie Ministra Rozwoju i Finansów z dnia 24 października 2016 r. w sprawie stawek karty podatkowej, kwoty, do której można wykonywać świadczenia przy prowadzeniu niektórych usług z wyjątkiem świadczeń dla ludności, oraz kwartalnych stawek ryczałtu od przychodów proboszczów i wikariuszy, obowiązujących w 2017 r. (M.P. poz. II20). 
Obwieszczenie Ministra Spraw Zagranicznych z dnia 29 lipca 1999 r. o wykonaniu Konkordatu między Stolicą Apostolską i Rzecząpospolitą Polską (Dz.U. Nr 63, poz. 727).

Pismo Naczelnej Rady Staroobrzędowców z dnia 17.I2.I998 r. do Ministerstwa Sprw Wewnętrznych i Administracji, DD/DDI8/99 (archiwum prywatne autora, sygn. WKs/I).

Porozumienie pomiędzy Naczelną Radą Kościoła Zielonoświątkowego w Rzeczypospolitej Polskiej oraz Ministrem Edukacji Narodowej z dnia I2 lipca 2012 r. w sprawie kwalifikacji zawodowych wymaganych od nauczycieli religii („Dziennik Urzędowy Ministra Edukacji Narodowej” poz. I4).

Porozumienie pomiędzy Zarządem Kościoła Adwentystów Dnia Siódmego oraz Ministrem Edukacji Narodowej z dnia I3 lutego I995 r. w sprawie kwalifikacji zawodowych wymaganych od nauczycieli religii („Dziennik Urzędowy Ministra Edukacji Narodowej” Nr 3, poz. 7).

Porozumienie z dnia 6 września 2000 r. pomiędzy Konferencją Episkopatu Polski oraz Ministrem Edukacji Narodowej w sprawie kwalifikacji wymaganych od nauczycieli religii („Dziennik Urzędowy Ministra Edukacji Narodowej" $\mathrm{Nr}$ 4, poz. 20).

Powszechna Deklaracja Praw Człowieka z dnia io grudnia 1948 r. przyjęta i proklamowana rezolucją Zgromadzenia Ogólnego ONZ 217A/III z dnia Io grudnia 1948 r., [w:] Wybór dokumentów prawa międzynarodowego dotyczacych praw cztowieka, red. M. Zubik, Warszawa 2008, s. II-I6.

Protokół (Nr 30) w Sprawie Stosowania Karty Praw Podstawowych Unii Europejskiej do Polski i Zjednoczonego Królestwa (Dz.Urz. UE. CNr 326 z 20I2 r., s. 313).

Rozporządzenie austriackiego Ministerstwa Wyznań i Oświecenia z dnia I8 października I877 r., którem orzeczone zostanie uznanie społeczności religijnej starokatolickiej („Dziennik Ustaw Państwa dla Królestw i Krajów w Radzie Państwa Reprezentowanych” Nr 99, s. 210).

Rozporządzenie Ministra Administracji Publicznej z dnia 23 marca 1946 r. („Dziennik Urzędowy Ministra Administracji Publicznej” z dnia 24 października 1947 r., s. 8).

Rozporządzenie Ministra Administracji Publicznej z dnia 6 sierpnia I949 r. w sprawie wykonania dekretu z dnia 5 sierpnia 1949 r. o zmianie niektórych przepisów prawa o stowarzyszeniach (Dz.U. Nr 47, poz. 358).

Rozporządzenie Ministra Edukacji Narodowej z dnia I4 kwietnia 1992 r. w sprawie warunków i sposobu organizowania nauki religii w publicznych przedszkolach i szkołach (Dz.U. Nr 36, poz. I55 z późn. zm.). 
Rozporządzenie Ministra Spraw Wewnętrznych i Administracji z dnia 3I marca 1999 r. w sprawie rejestru kościołów i innych związków wyznaniowych (Dz.U. Nr 38, poz. 374).

Rozporządzenie Prezesa Rady Ministrów z dnia 20 czerwca 2002 r. w sprawie „Zasad techniki prawodawczej” (tekst jedn. Dz.U. z 2016 r. poz. 283).

Rozporządzenie Prezydenta Rzeczypospolitej z dnia I4 października 1927 r. o uporządkowaniu stanu prawnego w organizacji gmin wyznaniowych żydowskich na obszarze Rzeczypospolitej Polskiej z wyjątkiem województwa śląskiego (tekst jedn. Dz.U. z 1928 r. Nr 52, poz. 500 z późn. zm.).

Rozporządzenie Prezydenta Rzeczypospolitej z dnia 22 marca 1928 r. o stosunku Państwa do Wschodniego Kościoła Staroobrzędowego, nie posiadającego hierarchji duchownej (Dz.U. Nr 38, poz. 363 z późn. zm.).

Rozporządzenie Rady Ministrów z dnia Io grudnia 1938 r. o uznaniu Statutu Wewnętrznego Polskiego Autokefalicznego Kościoła Prawosławnego (Dz.U. $\mathrm{Nr}$ I03, poz. 679).

Rozporządzenie Rady Ministrów z dnia 30 grudnia 198I r. w sprawie szczególnych przywilejów dla pracowników górnictwa - Karta górnika (Dz.U. z I982 r. Nr 2, poz. I3).

Rozstrzygnięcie nadzorcze Wojewody Dolnośląskiego dnia I marca 2oro r., NK-II.AL4.09II-5/IO, Legalis nr 544325.

Tymczasowe przepisy o stosunku Rządu do Kościoła Prawosławnego w Polsce z dnia 30 stycznia 1922 r. wydane przez Ministra Wyznań Religijnych i Oświecenia Publicznego (M.P. Nr 38, poz. 20).

Uchwała Nr xxxıII/354/20I3 Rady Miejskiej w Toszku z dnia 26 czerwca $2013 \mathrm{r}$. w sprawie zasad usytuowania miejsc sprzedaży i podawania napojów alkoholowych na terenie Gminy Toszek („Dziennik Urzędowy Województwa Śląskiego" poz. 4736).

Uchwała Sejmu Rzeczypospolitej Polskiej z dnia 30 lipca 1992 r. Regulamin Sejmu Rzeczypospolitej Polskiej (M.P. z 2012 r., poz. 32 z późn. zm.).

Urząd do spraw Wyznań, Decyzja z dnia I0.05.1974 r., Nr NK-803/2I/I/74.

Urząd do spraw Wyznań, Decyzja z dnia 30.IO.I984 r. Nr NK-803/29/I/84.

Ustawa dnia 3I stycznia 1959 r. o cmentarzach i chowaniu zmarłych (tekst jedn. Dz.U. z 2015 r. poz. 2126 z późn. zm.).

Ustawa z dnia 12 marca 2004 r. o pomocy społecznej (tekst jedn. Dz.U. z 2016 r. poz. 930 z późn. zm.). 


\section{Bibliografia}

Ustawa z dnia I3 maja I994 r. o stosunku Państwa do Kościoła Ewangelicko-Reformowanego w Rzeczypospolitej Polskiej (tekst jedn. Dz.U. z 2015 r. poz. 483 ).

Ustawa z dnia I3 maja I994 r. o stosunku Państwa do Kościoła Ewangelicko-Augsburskiego w Rzeczypospolitej Polskiej (tekst jedn. Dz.U. z 20I5 r. poz. 43).

Ustawa z dnia I3 października 1998 r. o systemie ubezpieczeń społecznych (tekst jedn. Dz.U. z 2016 r. poz. 963 z późn. zm.).

Ustawa z dnia I7 listopada 1964 r. Kodeks postępowania cywilnego (tekst jedn. Dz.U. z 2016 r. poz. I822).

Ustawa z dnia 17 maja 1989 r. o gwarancjach wolności sumienia i wyznania (tekst jedn. Dz.U. z 2005 r. Nr 231, poz. 1965 z późn. zm.).

Ustawa z dnia 17 marca I92I r. Konstytucja Rzeczypospolitej Polskiej (Dz.U. $\mathrm{Nr}$ 44, poz. 267 z późn. sprost.).

Ustawa z dnia I8 stycznia I95I r. o dniach wolnych od pracy (tekst jedn. Dz.U. z 20I5 r. poz. 90).

Ustawa z dnia 20 listopada 1998 r. o zryczałtowanym podatku dochodowym od niektórych przychodów osiąganych przez osoby fizyczne (Dz.U. Nr I44, poz. $930 \mathrm{z}$ późn. zm.).

Ustawa z dnia 20 lutego 1997 r. o stosunku Państwa do gmin wyznaniowych żydowskich w Rzeczypospolitej Polskiej (tekst jedn. Dz.U. z 20I4 r. poz. 1798).

Ustawa z dnia 20 lutego 1997 r. o stosunku Państwa do Kościoła Katolickiego Mariawitów w Rzeczypospolitej Polskiej (tekst jedn. Dz.U. z 20I5 r. poz. 44).

Ustawa z dnia 20 lutego 1997 r. o stosunku Państwa do Kościoła Starokatolickiego Mariawitów w Rzeczypospolitej Polskiej (tekst jedn. Dz.U. z 2015 r. poz. I4).

Ustawa z dnia 20 lutego 1997 r. o stosunku Państwa do Kościoła Zielonoświątkowego w Rzeczypospolitej Polskiej (tekst jedn. Dz.U. z 2015 r. poz. 13).

Ustawa z dnia 20 maja I97I r. z dnia Kodeks wykroczeń (tekst jedn. Dz.U. z 2015 r. poz. 1094 z późn. zm.).

Ustawa z dnia 2I kwietnia 1936 r. o stosunku Państwa do Karaimskiego Związku Religijnego w Rzeczypospolitej Polskiej (Dz.U. Nr 30, poz. 24I z późn. zm.).

Ustawa z dnia 2I kwietnia 1936 r. o stosunku Państwa do Muzułmańskiego Związku Religijnego w Rzeczypospolitej Polskiej (Dz.U. Nr 30, poz. 240 z późn. zm.).

Ustawa z dnia 2I marca I890 r. o urządzeniu stosunków prawnych zewnętrznych społeczności religii izraelickiej („Dziennik Ustaw Państwa dla Królestw 
i Krajów w Radzie Państwa Reprezentowanych” z I890 r., cz. I8, Nr 57 , s. IO9-II3).

Ustawa z dnia 23 czerwca 1939 r. o uregulowaniu stanu prawnego majątków Kościoła Prawosławnego (Dz.U. Nr 57, poz. 370).

Ustawa z dnia 23 kwietnia 1925 r. o zatwierdzeniu układu ze Stolicą Apostolską, określającego stosunek państwa do Kościoła Rzymsko-Katolickiego (Dz.U. $\mathrm{Nr}$ 47, poz. 324).

Ustawa z dnia 24 kwietnia 2003 r. o działalności pożytku publicznego i o wolontariacie (tekst jedn. Dz.U. z 2016 r. poz. I8I7).

Ustawa z dnia 26 czerwca $1997 \mathrm{r}$. o zmianie ustawy o gwarancjach wolności sumienia i wyznania oraz o zmianie niektórych ustaw (Dz.U. z 1998 r. Nr 59, poz. 375).

Ustawa z dnia 26 października 1982 r. o wychowaniu w trzeźwości i przeciwdziałaniu alkoholizmowi (tekst jedn. Dz.U. z 2016 r. poz. 487 z późn. zm.).

Ustawa z dnia 26 stycznia 1982 r. Karta Nauczyciela (tekst jedn. Dz.U. z 2016 r. poz. 1379 z późn. zm.)

Ustawa z dnia 29 lipca 2005 r. o przeciwdziałaniu narkomanii (tekst jedn. Dz.U. z 2016 r. poz. 224 z późn. zm.).

Ustawa z dnia 29 stycznia 2004 r. Prawo zamówień publicznych (tekst jedn. Dz.U. z 2015 r. poz. 2164 z późn. zm.).

Ustawa z dnia 30 czerwca 1995 r. o stosunku Państwa do Kościoła Adwentystów Dnia Siódmego w Rzeczypospolitej Polskiej (tekst jedn. Dz.U. z 20I4 r. poz. I889).

Ustawa z dnia 30 czerwca 1995 r. o stosunku Państwa do Kościoła Ewangelicko-Metodystycznego w Rzeczypospolitej Polskiej (tekst jedn. Dz.U. z 2014 r. poz. I7I2).

Ustawa z dnia 4 lipca 199I r. o stosunku Państwa do Polskiego Autokefalicznego Kościoła Prawosławnego (tekst jedn. Dz.U. z 20I4 r. poz. 1726).

Ustawa z dnia 4 marca 2010 r. o narodowym spisie powszechnym ludności i mieszkań w 20II r. (Dz.U. Nr 47, poz. 277).

Ustawa z dnia 5 czerwca 1998 r. o samorządzie województwa (tekst jedn. Dz.U. z 2016 r. poz. 486).

Ustawa z dnia 5 lipca 1990 r. Prawo o zgromadzeniach (Dz.U. Nr 51, poz. 297).

Ustawa z dnia 6 czerwca 1997 r. Kodeks karny (tekst jedn. Dz.U. z 2016 r. poz. II37 poz. II37 z późn. zm.).

Ustawa z dnia 6 września 20oI r. o dostępie do informacji publicznej (tekst jedn. Dz.U. z 2016 r. poz. I764). 
Ustawa z dnia 7 kwietnia 1989 r. Prawo o stowarzyszeniach (tekst jedn. Dz.U. z 2015 r. poz. 1393 z późn. zm.).

Ustawa z dnia 7 września I99I r. o systemie oświaty (tekst jedn. Dz.U. z 2016 r. poz. 1943 z późn. zm.).

Ustawa z dnia 9 kwietnia 20 Io r. o Służbie Więziennej (tekst jedn. Dz.U. z 2016 r. poz. 713 z późn. zm.).

Ustawa z dnia z dnia 30 czerwca 1995 o stosunku Państwa do Kościoła Polskokatolickiego w Rzeczypospolitej Polskiej (tekst jedn. Dz.U. z 2014 r. poz. 1599).

Ustawa z dnia I7 maja 1989 r. o stosunku Państwa do Kościoła Katolickiego w Rzeczypospolitej Polskiej (tekst jedn. Dz.U. z 20I3 r. poz. II69 z późn. zm.). Ustawa z dnia 23 kwietnia 1964 r. Kodeks cywilny (tekst jedn. Dz.U. z 2016 r. poz. I822 z późn. zm.)

Zarządzenie Ministra Wyznań Religijnych i Oświecenia Publicznego z dnia 6 maja 1939 r. zatwierdzające Statut Konsystorzy Diecezjalnych Polskiego Autokefalicznego Kościoła Prawosławnego (M.P. Nr 136, poz. 319).

О управленіи дълами Евангелическо-Реформатской Церкви въ губерніяхъ Царства Польскаго, 8 Февраль I849 (Ustawa z dnia 8 lutego I849 r. o zarządzie spraw Kościoła Ewangelicko-Reformowanego w Królestwie Polskim), „Свод законов Российской империи” (Zbiór Praw Imperium Rosyjskiego), Санкпетербургъ I857, Книга третья, Томъ хі, Часть I, Глава II, No. Іо27-Іо35).

О форме книгъ для записи браков, рождения и смерти баптистовъ, 29 сентября І879, (Zasady z dnia 29 września I879 r. dotyczące prowadzenie ksiag przez Baptystów) „Полное собрание законов Российской империи” (Pełny Zbiór Praw Imperium Rosyjskiego), b.m.w. I9I2, Том 54, Часть 2, №. 60169.

Объ исповьдующихъ вьроученіе маріавитовъ, І марта І9І2 (Zasady z dnia II marca I9I2 dotyczące wyznawców Kościoła mariawitów), „Полное собрание законов Российской Империиб" (Pełny Zbiór Praw Imperium Rosyjskiego), Петроградъ І9г5, Третье собрание, Том хххіг, Часть I, No. 36718.

\section{Judykaty}

Orzeczenie Sądu Apelacyjnego w Poznaniu z dnia I8 sierpnia 1946 r., I CZ 83/46 za K. Skubiszewski, Konkordat z Io lutego I925 r. Zagadnienia prawnomiędzynarodowe, [w:] Kościót w II Rzeczypospolitej, red. Z. Zieliński, S. Wilk, Lublin 1980, s. 46.

Orzeczenie Sądu Najwyższego - Izba Cywilna z I7 lutego 2005 r., IV CK 582/04, Legalis nr 89892. 


\section{Bibliografia}

Orzeczenie Sądu Najwyższego - Izba Cywilna z dnia I2 marca I997 r., II CKN 24/97, Legalis nr 6336r.

Orzeczenie Sądu Najwyższego - Izba Cywilna z dnia 27 lipca 2000 r., IV CKN 88/oo, Legalis nr 54815.

Orzeczenie Sądu Najwyższego - Izba Cywilna z dnia 24 marca 2004 r., IV CK IO8/03, Legalis nr 67840.

Orzeczenie Sądu Najwyższego - Izba Cywilna z dnia 2 lutego 2005 r., IV CK 480/04, Legalis nr 87008.

Postanowienie Naczelnego Sądu Administracyjnego z dnia 4 lipca 2012 r., II FZ 456/I2, Legalis nr 512435.

Postanowienie Sądu Najwyższego - Izba Cywilna z dnia I2 stycznia 20II r., I CSK I82/Io, Legalis nr 309866.

Postanowienie Trybunału Konstytucyjnego z dnia I2 października 20II r., Ts 329/o8, Lex nr II24545.

Postanowienie Wojewódzkiego Sądu Administracyjnego siedziba w Poznaniu z dnia 28 października 2013 r., I SA/po 755/133, Legalis nr 984043.

Supremum Tribunal Signaturae Apostolicae, Decretum die 25 Iunii 1994, prot. 24048/93 CA, [w:] Ministerium Iustitiae. Jurisprudence of the Supreme Tribunal of the Apostolic Signature. Official Latin with English Translation, transl. W. L. Daniel, Montreal 20II, s. 476-48I.

Supremum Tribunal Signaturae Apostolicae, Decretum die 5 maii 1990, prot. I806I/86 CA, [w:] Ministerium Iustitiae. Jurisprudence of the Supreme Tribunal of the Apostolic Signature. Official Latin with English Translation, transl. W. L. Daniel, Montreal 20II, s. 260-274.

Uchwała Sądu Najwyższego - Izba Cywilna z dnia I9 grudnia 2008 r., III CZP I22/O8, Legalis nr II2754.

Uchwała Sądu Najwyższego - Izba Karna z dnia 29 października 2012 r., I KZP I2/I2, Legalis nr 538443 .

Uchwała Trybunału Konstytucyjnego z dnia 6 listopada 199I r., w 2/91, Legalis nr IOIO4. Wyrok Europejskiego Trybunału Praw Człowieka z dnia 25 maja 1993 r., I4307/88, Kokkinakis przeciwko Grecji, I4307/88, Legalis nr 135567.

Wyrok Naczelnego Sądu Administracyjnego z dnia I6 stycznia 2002 r., III SA 2302/oo, Legalis nr 52899.

Wyrok Naczelnego Sądu Administracyjnego z dnia 8 stycznia 2008 r., II GSK 286/07, Legalis nr 96023.

Wyrok Sądu Antymonopolowego z dnia 26 marca 1993 r., XVII Amr 46/92, Legalis $\mathrm{nr} 45 \mathrm{I2} 3$. 
Wyrok Sądu Antymonopolowego z dnia 23 kwietnia 20oI r., XVII Ama 49/oo, Legalis nr 65615.

Wyrok Sądu Najwyższego - Izba Cywilna z dnia 25 lutego 2OI5 r. IV CSK 3I2/I4, Legalis nr I213092.

Wyrok Sądu Najwyższego z dnia I7 grudnia I984 r., IV PR 225/84, Legalis nr 24525. Wyrok Sądu Najwyższego - Izba Pracy, Ubezpieczeń Społecznych i Spraw Publicznych z dnia 3 marca 2005 r., I PK 263/04, Legalis nr 70094.

Wyrok Sądu Okręgowego - Sądu Ochrony Konkurencji i Konsumentów z dnia I2 stycznia 2006 r., XVII Ama I05/04, Legalis nr 788oI.

Wyrok Trybunału Konstytucyjnego z dnia I6 lutego 1999 r., SK II/98, Legalis nr 43177.

Wyrok Trybunału Konstytucyjnego z dnia 7 grudnia 1999 r., K 6/99, Legalis nr 45625 .

Wyrok Trybunału Konstytucyjnego z dnia I4 grudnia I999 r., SK I4/98, Legalis nr 45628.

Wyrok Trybunału Konstytucyjnego z dnia 20 grudnia 1999 r., K 4/99, Legalis nr 45630 .

Wyrok Trybunału Konstytucyjnego z dnia 30 stycznia 200I r., K I7/oo, Legalis nr 49436.

Wyrok Trybunału Konstytucyjnego z dnia 2I marca 200I r., K 24/o0, Legalis nr 49669.

Wyrok Trybunału Konstytucyjnego z dnia 3 października 200I r., K 27/OI, Legalis nr 50909.

Wyrok Trybunału Konstytucyjnego z dnia 2 kwietnia 2003 r., K I3/o2, Legalis nr 5666I.

Wyrok Trybunału Konstytucyjnego z dnia 7 czerwca 2004 r., P 4/o3, Legalis nr 63693 .

Wyrok Trybunału Konstytucyjnego z dnia II maja 2005 r., K I8/O4, Legalis nr 68382 .

Wyrok Trybunału Konstytucyjnego z dnia I6 stycznia 2006 r., sK 30/O5, Legalis nr 72310.

Wyrok Trybunału Konstytucyjnego z dnia I3 marca 2006 r., P 8/05, Legalis nr 72932.

Wyrok Trybunału Konstytucyjnego z dnia 9 października 2007 r., sK 70/o6, Legalis nr 87215.

Wyrok Trubunału Konstytucyjnego z dnia 28 października 2009 r., Kp 3/o9, Legalis nr 17563 I. 


\section{Bibliografia}

Wyrok Trybunału Konstytucyjnego z dnia 2 grudnia 2009 r., U Io/o7, Legalis nr 178953.

Wyrok Trybunału Konstytucyjnego z dnia I4 grudnia 2009 r., K 55/07, Legalis nr 180038 .

Wyrok Trybunału Konstytucyjnego z dnia 27 października 20 IO r., K Io/o8, Legalis nr 254429.

Wyrok Trybunału Konstytucyjnego z dnia I9 grudnia $20 \mathrm{O} 2$ r., K 9/I2, Legalis nr 549608 .

Wyrok Wojewódzkiego Sądu Administracyjnego w Opolu z dnia 8 kwietnia 2015 r., I SA/Op 24/15, Legalis nr I272575.

Wyrok Wojewódzkiego Sądu Administracyjnego w Warszawie z dnia 8 kwietnia 2014 r., I SA/Wa I5I7/I3, Legalis nr 95098I.

Wyrok Wojewódzkiego Sądu Administracyjnego w Warszawie z dnia I 9 lutego 2015 r., I SA/Wa 2240/I4, Lex nr I654939.

Wyrok Wojewódzkiego Sądu Administracyjnego w Warszawie z dnia 27 października 2015 r., I SA/Wa I250/I5, Lex nr 2030528.

\section{Literatura przedmiotu}

Abbass J., Two Codes in Comparison, Roma 2007.

Almanach żydowski 5776 (2015-20I6), red. B. Szwarcman-Czarnota, Warszawa 2015 .

Sobczak J., Potożenie prawne polskich wyznawców islamu, [w:] Islam a świat, red. R. Bräcker, S. Kitab, Toruń 2003, s. 172-204.

Amen M., Canonical Equity before the Code, „The Jurist” 33 (1973), s. 4-24. Annuario pontificio 20I5, Città del Vaticano 20I5.

Arystoteles, Etyka nikomachejska, przeł. D. Gromska, Warszawa 1956.

Augustine, De Trinitate, Brepolis 1968.

Aymans W., Mörsdorf K., Kanonisches Recht. Lehrbuch aufgrund des Codex Iuris Canonici, t. I: Einleitende Grundfragen und Allgemeine Normen, Paderborn I99I. Bączkowicz F., Prawo kanoniczne. Podręcznik dla duchowieństwa, t. 2, przygotowali do druku i uzupełnili J. Baron i W. Stawinoga, Opole $1958^{3}$.

Banaszak B., Konstytucja Rzeczypospolitej Polskiej. Komentarz, Warszawa 2012. Bator A. i inni, Wprowadzenie do nauk prawnych. Leksykon tematyczny, Warszawa 2008.

Bendza M., Droga Kościota prawostawnego w Polsce do autokefalii, Białystok 2006. Benedyktowicz W., Zasady Ogólne Kościota Metodystycznego, „Pielgrzym Polski” (198I) nr 50I, s. 3-4. 


\section{Bibliografia}

Bielawski J., Islam jako religia światowa, [w:] Zarys dziejów religii, red. J. Keller i inni, Warszawa 1988, s. 769-798.

Bierzanek R., Symonides J., Prawo międzynarodowe publiczne, Warszawa 2005.

Borecki P., Autonomia kościotów i innych związków wyznaniowych we wspótczesnym prawie polskim, „Studia z Prawa Wyznaniowego” I5 (20I2), s. 85-I09.

Borecki P., Potożenie prawne wyznawców islamu w Polsce, „Państwo i Prawo"(2008) z. I, s. 72-84.

Borecki P., Przeżytki ustawodawstwa wyznaniowego w polskim systemie prawnym, „Studia Iuridica” 59 (20I4), s. 4I-57.

Borecki P., Status prawny muzutmanów we wspótczesnej Polsce (I), „Przegląd Tatarski” (20II) nr I, s. 26-28.

Borecki P., Status prawny muzutmanów we wspótczesnej Polsce (2), „Przegląd Tatarski” (20II) nr 2, s. 26-28.

Borecki P., Status prawny muzutmanów we wspótczesnej Polsce (3), „Przegląd Tatarski” (2OII) nr 4, s. I7-I9.

Borecki P., Panstwo laickie. Wspótczesna rzeczywistość ustrojowa i perspektywa na przysztośc, „Ruch Prawniczy, Ekonomiczny i Socjologiczny” 69 (2007) z. 2, s. 6I-79.

Borucka-Arctowa M., Problem wartościowania w naukach prawnych, „Państwo i Prawo" (1968) z. 3, s. 429-437.

Brundage J. A., Medieval Canon Law, London-New York 1995.

Chauvin T., Stawecki T., Winczorek W., Wstęp do prawoznawstwa, Warszawa 201 .

Chidester D., Authentic Fakes. Religion and American Popular Culture, Berkeley 2005 .

Chodun A., Gomułowicz A., Skoczylas A., Klauzule generalne i zwroty niedookreślone $w$ prawie podatkowym $i$ administracyjnym. Wybrane zagadnienia teoretyczne i orzecznicze, Warszawa 2013.

Choduń A., Zieliński M., Interpretacyjna rola wstępów aktów prawnych, [w:] Wokót konstytucji i zdrowego rozsadku. Prace dedykowane Profesorowi Tadeuszowi Smolińskiemu, red. J. Ciapała, A. Rost, Szczecin-Jarocin 20II, s. I5-25.

Condor S., Interpretation of Legal Discourse, Create Space Independent Publishing Platform 20I3, s. 247-26I.

Coughlin J. J., Canonical Equity, „Studia Canonica” 30 (1996), s. 403-435.

Cussack M., Invented Religions. Imagination, Fiction and Faith, Burlirigton 2010.

Czarzasty J., Przyczynek do problematyki klauzul generalnych, „Państwo i Prawo” (1978) z. 5, s. 83-92. 
Czochara A., Zakres podmiotowy art. 25 ust. 5 Konstytucji RP, [w:] Uktadowe formy regulacji stosunków między państwem a zwiąkami wyznaniowymi (art. 25 ust. 4-5 Konstytucji RP), red. P. Stanisz, M. Ordon, Lublin 2013, s. $253-262$.

Czohara A., Zieliński T. J., Ustawa o stosunku państwa do gmin wyznaniowych zydowskich $w$ Polsce. Komentarz, Warszawa 2012.

Daniel K., Kontrowersje wokót wprowadzenia wartości chrześcijańskich do prawa, [w:] Dynamika wartości w prawie, red. K. Pałecki, Kraków 1997, s. 157-207.

Dawson J. P., The General Clauses Viewed From a Distance, „Rabels Zeitschrift für ausländisches und internationales Privatrecht" 4I (1977) Heft 3,s. 44I-456.

Demiańczuk J., Uznanie prawne wyznań w świetle konstytucji, „Państwo i Prawo” (1948) z. 5-6, s. 45-48.

Dictionnaire de droit canonique, sous la direction de R. Naz, vol. 5, Paris 1953.

Dizionario teologico interdisciplinare, a cura di L. Pacomio, t. I, Torino 1977.

Donahue Ch., A Crisis of Law? Reflections on the Church and the Law Over the Centuries, „The Jurist” 65 (2005), s. I-30.

Czarny P., Opinia prawna w sprawie obowiazku zasiegania opinii co do zmian w ustawach regulujacych stosunek państwa do poszczególnych kościotów i związków wyznaniowych, „Zeszyty Prawnicze Biura Analiz Sejmowych Kancelarii Sejmu" 36 (20I2) nr 4, s. 78-86.

Daniel K., Kontrowersje wokót wprowadzenia wartości chrześcijańskich do prawa, [w:] Dynamika wartości w prawie, red. K. Pałecki, Kraków 1997, s. 157-207.

Dudek D., Równouprawnienie kościotów i związków wyznaniowych na tle konstytucyjnych zasad prawa wyznaniowego, [w:] Prawo wyznaniowe w systemie prawa polskiego. Materiaty i Ogólnopolskiego Sympozjum Prawa Wyznaniowego (Kazimierz Dolny, I4-I6 stycznia 2003), red. A. Mezglewski, Lublin 2004, s. 199-225.

Działocha K., Zamknięty system źródet prawa powszechnie obowiąujacego w konstytucji i praktyce, [w:] Konstytucyjny system źródet prawa w praktyce, red. A. Szmyt, Warszawa 2005, s. 9-34.

Dzieto Wielkiego Mitosierdzia dla świata czyli Wypetnienie się objawienia św. Jana Apostota na staro-katolickim kościele maryawitów, Płock 1922.

Dziewiatowski M., Wspólnota parafialna jako element historycznego trwania Kościota powszechnego. Studium przypadku sosnowieckiej wspólnoty parafialnej, 20I4, rękopis, praca doktorska nieopublikowana, w posiadaniu autora.

Elaide M., Mity, sny i misteria, przeł. K. Kocjan, Warszawa 1994. 
Nalborczyk, Status prawny muzutmanów w Polsce i jego wptyw na organizację ich życia religijnego, [w:] Muzutmanie w Europie, red. A. Parzymies, Warszawa 2005, s. 229-239.

Evdokimov P., Prawostawie, przeł. J. Klinger, Warszawa 2003.

Failinger M. A., Keifert P. R., Making Our Home in the Works of God: Lutherans on the Civil use of the Law, [w:] Christian Perspective on Legal Thought, ed. M. W. McConnell, R. F. Cochran, Jr., A. C. Carmella, New Heaven-London 200I, s. 386-405.

Fuller L., The Morality of Law, New Haven 1967.

Gaakeer J., Introduction. Multi and Interdisciplinarity: Mere Theory or Just Practice?, „Erasmus Law Review” 3 (2008) issue 3, s. I-2.

Gałkowski T., Prawo naturalne fundamentem kazdego prawa?, „Annales Canonici" 7 (20II), s. 5-17.

Gangoiti B., Teologia e filosofia del diritto del nuovo codice, „Angelicum” 60 (1983), s. 517-533.

Gerosa L., Interpretacja prawa w Kościele. Zasady, wzorce, perspektywy, przeł. K. Kubiś, A. Porębski, Kraków 2003.

Gierat K., Problematyka matżeństw mieszanych $w$ kontekście wypetniania istotnych praw-obowiązków matżeńskich, „Ius Matrimoniale” 5 (2000), s. 63-IOI.

Główny Urząd Statystyczny, Rocznik demograficzny 2013, Warszawa 2013.

Główny Urząd Statystyczny, Rocznik demograficzny 20I4, Warszawa 2014.

Główny Urząd Statystyczny, Wyznania religijne, stowarzyszenia narodowościowe i etniczne w Polsce 2009-20II, Warszawa 2013.

Góralczyk W., Sawicki S., Prawo międzynarodowe publiczne w zarysie, Warszawa 2009.

Góralski W., Wstęp do prawa wyznaniowego, Płock 2003.

Goryczko E., Autonomia i samorzadność zwiąków wyznaniowych $w$ Polsce Ludowej, Tarnów 2005.

Granat M., Granice wolności religijnej w spoteczeństwie pluralistycznym, [w:] Kultura i prawo: materiaty III Międzynarodowej Konferencji na temat „Religia i wolność religijna w Unii Europejskiej", Warszawa, 2-4 września 2002, red. J. Krukowski, O. Theisen, s. 173-192.

Greenawalt K., Legal Interpretation. Perspectives from other Disciplines and Private Text, Oxford 2010.

Groff P. S., Leaman O., Islamic Philosophy A-Z, Edinburgh 2007.

Grundmann S., Mazeaud D., General Clauses and Standards in European Contract Law: Comparative Law, EC Law and Contract Law Codification, Hague 2006. 
Hall T. L., „Incendiaries of Commonwealths”: Baptists and Law, [w:] Christian Perspective on Legal Thought, ed. M. W. McConnell, R. F. Cochran, Jr., A. C. Carmella, New Heaven-London 200I, s. 340-354.

Hallaq W. B., A History of Islamic Legal Theories, Cambridge 1997.

Heckel J., Lex charitatis: a Juristic Disquisition on Law in the Theology of Martin Luther, transl. and ed. G. G. Krodel, H. F. Falkenstein, J. A. Hiller, Grand Rapids 20 Io. Hintz M., Neutralność religijna państwa w kontekście luterańskiej nauki o dwóch wtadzach, [w:] Bezstronność religijna, światopogladowa i filozoficzna wtadz Rzeczypospolitej Polskiej, red. T. J. Zieliński, Warszawa 2009, s. I3-15.

Ivo Carnotensis, Epistula 6o, [w:] Ivo Carnotensis, Opera omnia, accurante J. P. Migne, Parisiis 1854, kol. 70-75 (Patrologiae cursus completus. Series Latina, I62).

Iwaniec E., $Z$ dziejów staroobrzędowców na ziemiach polskich XVII-XX wieku, Warszawa 1977.

Jachter Ch., Gray Matter. Exproring Contemporary Hallachic Challenges, vol. 3, Teanec 2008.

Januchowski A., Glosa do wyroku NSA z dnia 8 stycznia 2008, II GSK 286/o7, „Orzecznictwo Sądów Polskich” (2009) z. 2, poz. I8.

Johannes Chrysostomus, Homilia XVI, [w:] Johannes Chrysostomus, Opera omnia quae exstant, accurante J. P. Migne, Parisiis 1862, kol. 237-254 (Patrologiae cursus completus. Series Graeca, 57).

Jougan A., Stownik kościelny tacińsko-polski, Poznań-Warszawa-Lublin 1958.

Julia D., Stownik filozofii, przeł. K. Jarosz, Katowice 1995.

Kamali M., An Introduction to Shari'ah, Kuala Lumpur 2006.

Karski K., Stan recepcji „Lumen gentium” $i$,Unitatis redintegratio” z perspektywy ewangelicko-luterańskiej, [w:] Kościót i dialog: materiaty z sympozjum zorganizowanego $z$ okazji 40. rocznicy promulgacji "Lumen gentium” $i$ "Unitatis redintegratio", Lublin 2I-22 listopada 2004 roku, red. A. Czaja, L. Górka, V. Kmiecik, Lublin 2005, s. 137-I46.

Keller J., Religia, [w:] Zarys dziejów religii, red. J. Keller i inni, Warszawa 1988, s. 5-49. Klob R., Jedność wyznania - droga do Formuty zgody, red. i przypisy M. Uglorz, tłum. K. Undas, [w:] Księgi wyznaniowe Kościoła luterańskiego, Bielsko-Biała 20II, s. 373-386.

Kodeks karny. Komentarz, red. R. Stefański, Beck Online Komentarze (27.0I.20I4), Legalis.

Kodeks Prawa Kanonicznego. Komentarz, red. P. Majer, wyd. pol. na podst. wyd. hiszp., Kraków 2011. 
Konstytucja Rzeczypospolitej Polskiej. Komentarz, red. L. Garlicki, t. 5, Warszawa 2007. Krasowski K., Zwiazki wyznaniowe w II Rzeczypospolitej. Studium historycznoprawne, Warszawa-Poznań 1988, s. 272-289.

Kroczek P., Co prawodawca miat na myśli? - czyli czym jest „mens legislatoris” i gdzie jej szukać?, „Annales Canonici” 3 (2007), s. I87-198.

Kroczek P., Czy system prawa kanonicznego może być wzorcem dla systemu prawnego federacji państw?, „Prawo Kanoniczne” 59 (2016) nr 2, s. 73-87.

Kroczek P., Does the Catholic Vision of the Principle of Subsidiarity Pertain to Polish Family Law?, „Ecumeny and Law” 3 (2015), s. 327-340.

Kroczek P., „Ius sequitur vitam”, czyli o niektórych czynnikach zmian w prawie, „Studia Socialia Cracoviensia” 6 (20I4) nr 2 (II), s. I63-176.

Kroczek P., Kanoniczne zakazy zwiazane z matżeństwem jako możliwość wsparcia ściagalności alimentów na dzieci, „Polonia Sacra” 29 (201I), s. I79-I94.

Kroczek P., List do rodzin "Gratissimam sane” jako wskazówka dla prawodawstwa państwowego, [w:] Prawa dziecka: perspektywa Kościoła, red. P. Kroczek, Kraków 20I5, s. 8I-97 (Annales Canonici. Monographiae, 3).

Kroczek P., Matżeństwo konkordatowe - ewaluacja przepisów po is latach od wejścia w życie na przyktadzie przestanki z art. Io ust. I pkt I konkordatu, [w:] Konkordat - ocena z perspektywy Is lat obowiazywania, red. P. Kroczek, Kraków 20I4, s. I43-I62 (Annales Canonici. Monographiae, 2).

Kroczek P., Niedookreśloność i nieostrość zwrotów w prawie kanonicznym na przyktadzie KPK z 1983 r., „Annales Canonici” I (2005), s. 175-185.

Kroczek P., O pożytkach ze znajomości prawa Kościotów wschodnich dla prawodawcy tacińskiego, [w:] Semper fidelis, Vedecká konferencia s medzinárodnou účastou II. marec 20I0, red. F. Čitbaj, Prešov 20II, s. 36-42.

Kroczek P., Ocena instrukcji „Dignitas connubii” z perspektywy sztuki legislacji, „Prawo Kanoniczne” 58 (2015) nr I, s. 94-I09.

Kroczek P., Prawny wymiar troski Kościota o rozwój cztowieka i spoteczeństwa, [w:] Rozwój i dobro wspólne. Dyskurs w 25-lecie encykliki "Sollicitudo rei socialis" Jana Pawta II, red. J. Mazur, Kraków 20I2, s. 7I-87.

Kroczek P., Prawo kanoniczne wsparciem dla polskiego prawa rodzinnego: teoretyczne podstawy i praktyczne przykłady, „Bielsko-Żywieckie Studia Teologiczne" I4 (20I3), s. I3I-I45.

Kroczek P., Prawo świeckie jako bariera komunikacyjna dla niektórych treści nauczania Kościota o matżeństwie i rodzinie, [w:] Rodzina podmiotem wychowania i kreatorem komunikacji spotecznej, red. N. Pikuła, Kraków 20IO, s. 33I-344. 
Kroczek P., Skonieczny P., Preamble of Law: Perspective of Legislator and Interpreter, „Angelicum” 90 (2013) fascicle 4, s. 869-888.

Kroczek P., Status prawny mariawitów w Polsce, „Studia Oecumenica” I4 (20I4), s. $237-252$.

Kroczek P., Sumienie w prawie polskim, [w:] Sumienie. Ujęcie interdyscyplinarne, red. B. Gulla, M. Cholewa, Kraków 2015, s. 2I-38.

Kroczek P., Świętowanie w pedagogice prawa kanonicznego i prawa polskiego, „Polonia Sacra” 28 (20II), s. I69-187.

Kroczek P., Teologiczne podstawy regut sensu czynności konwencjonalnych i norm kompetencyjnych w prawie kanonicznym i ich konsekwencje dla decyzji prawodawczych, „Annales Canonici” 9 (2013), s. 55-73.

Kroczek P., Termin "fides" w optyce prawodawcy i interpretatora na przyktadzie KPK 1983, [w:] Wiara a prawo: między wolnościa a postuszeństwem, red. P. Kroczek, Kraków 2013, s. I43-159 (Annales Canonici. Monographiae, I). Kroczek P., The Art of Legislation: the Principles of Lawgiving in the Church, and rev. ed., Kraków 2012.

Kroczek P., Ulman P., Argument statystyczny w rejestracji Kościotów i związków wyznaniowych - przyczynek do dyskusji, „Opolskie Studia Administracyjno-Prawne" I3 (2015) nr I, s. 6I-82.

Kroczek P., Zasada "clara non sunt interpretanda" w prawie kanonicznym, wyd. 2 poprawione, Kraków 2005.

Król M., Pojęcie luzu normatywnego stosowania prawa, „Państwo i Prawo” (1979) z. 6, s. $62-72$.

Krukowski J., Autonomia i niezależność Kościota i wspólnoty politycznej, „Kościół i Prawo" 4 (1985), s. 5I-77.

Krukowski J., Funkcje publiczne a osobowość publicznoprawna Kościotów, [w:] Funkcje publiczne związków wyznaniowych. Materiaty III Ogólnopolskiego Sympozjum Prawa Wyznaniowego (Kazimierz Dolny, I6-I8 maja 2006), red. A. Mezglewski, Lublin 2007, s. 35-58.

Krukowski J., Konstytucyjny model stosunków między państwem a Kościotem w III Rzeczypospolitej, [w:] Prawo wyznaniowe w systemie prawa polskiego. Materiaty i Ogólnopolskiego Sympozjum Prawa Wyznaniowego (Kazimierz Dolny, I4-I6 stycznia 2003), red. A. Mezglewski, Lublin 2004, s. 79-IOI.

Krukowski J., Kościelne prawo publiczne. Prawo konkordatowe, Lublin 2013.

Krukowski J., Kościót i państwo. Podstawy relacji prawnych, Lublin 1993.

Krukowski J., Podstawowe zagadnienia prawa konkordatowego, „Studia Prawnicze" (1995) z. I-4, s. IO5-I34. 


\section{Bibliografia}

Krukowski J., Polskie prawo wyznaniowe, Warszawa 2008.

Krukowski J., Sobański R., Komentarz do Kodeksu Prawa Kanonicznego, t. I: Księga I, Normy ogólne, Poznań 2003.

Kubiak H., Narodowy Kościót Katolicki w Stanach Zjednoczonych Ameryki w latach 1897-1965. Jego spoteczne uwarunkowania i spoteczne funkcje, WrocławWarszawa-Kraków 1970.

Klauzule generalne w prawie krajowym i obcym, red. L. Zacharko, Katowice 2016.

Kustra E., Racjonalny ustawodawca. Analiza teorioprawna, Toruń 1980.

Lanckoroński B., Klauzula „rebus sic stantibus" a odpowiedzialnośc "ex contractu”, „Państwo i Prawo” (2012) z. 3, s. 65-74.

Lara R. C., Some Reflections of the Proper Way to Approach the Code of Canon Law, „CLSA Proceedings” 46 (1984), s. 24-40.

Leaman O., Ali L., Islam. The Key Concepts, London-New York 2008.

Leksykon prawa wyznaniowego. Ioo podstawowych pojęć, red. A. Mezglewski, Warszawa 2014.

Leszczyński L., Klauzule generalne w stosowaniu prawa, Lublin 1986.

Leszczyński L., Pojęcie klauzuli generalnej, „Annales Universitatis Mariae Curie-Skłodowska" 38 (I99I), s. I57-I72.

Leszczyński L., Praworządne stosowanie prawa a klauzule generalne, „Państwo i Prawo" (1989) z. II, s. 56-67.

Leszczyński L., Stosowanie generalnych klauzul odsytajacych, Kraków $200 \mathrm{I}$.

Leszczyński L., Tworzenie generalnych klauzul odsytajacych, Lublin 2000.

Leszczyński L., Zagadnienia teorii stosowania prawa doktryna i tezy orzecznictwa, Kraków 2004.

Leszczyński P., Zagadnienia wyznaniowe w Konstytucji $R P$, Warszawa $200 \mathrm{I}$.

Lewandowski S., Charakter normatywny preambuty, „Studia Iuridica” 36 (1998), s. $\mathrm{I} 13-\mathrm{I} 36$.

Lexikon des Kirchenrechts, Hrsg. S. Haering, H. Schmitz, Freiburg-Basel-Wien 2004.

Liśkiewicz M., Skuteczność norm prawa kanonicznego w polskim porzadku prawnym na przyktadzie wybranych stosunków cywilnoprawnych $z$ udziatem kościelnych osób prawnych, 2013, licencjat kościelny dostępny w Bibliotece Uniwersytetu Papieskiego Jana Pawła II w Krakowie.

Łopatka A., Prawo do wolności myśli, sumienia i religii, Warszawa 1995. Mączyński A., Skutki cywilne matżeństwa kanonicznego w świetle konkordatu i prawa polskiego, [w:] Konkordat 1993. Dar i zadania dla Kościota i Polski, red. J. Dyduch, Kraków 1998, s. 17-40. 


\section{Bibliografia}

Mączyński D., Sowiński R., Klauzule generalne oraz pojęcia niedookreślone w europejskim i krajowym prawie podatkowym a obejscie (nadużycie) prawa, [w:] Prawo europejskie - s lat doświadczeń w polskim prawie finansowym. Materiaty konferencyjne (Warszawa, I0-II.06.20I0 r.), red. H. Litwińczuk, Warszawa 20Io, s. 464-478.

Majer P., Odmowa (lub odroczenie) asystowania przy matżeństwie, [w:] Munus sanctificandi: gaudium vel onus? Zadanie uświęcania: radość czy ciężar?, red. B. W. Zubert, W. J. Sztyk, Katowice 2009, s. 59-79 (Szkoła Seraficka, 5).

Malinowski A., Polski tekst prawny. Opracowanie treściowe i redakcyjne, Warszawa 2012.

Malinowski A., Redagowanie tekstu prawnego. Wybrane wskazania logiczno-językowe, Warszawa 2006.

Mames T. D., Mysteria mysticorum: szkice z duchowości i historii mariawitów, Kraków 2009.

Maroń G., Zasady prawa. Pojmowanie i typologie a rola w wyktadni prawa i orzecznictwie konstytucyjnym, Poznań 2011.

Mez A., Renesans islamu, Warszawa 1979.

Mezglewski A., Misztal H., Stanisz P., Prawo wyznaniowe, Warszawa 201 .

Mezglewski A., Opinia prawna dotyczaca problemu obowiazywania prawa wewnętrznego związków wyznaniowych w obrocie prawnym, „Przegląd Prawa Wyznaniowego" 3 (20II), s. 25I-258.

Mezglewski A., Spór o wygá́nięcie konkordatu polskiego z 1925 roku, „Roczniki Nauk Prawnych" 8 (1988), s. 325-240.

Michiels G., Normae generales iuris canonici, t. I, Parisiis-Tornaci-Romae I949.

Misztal H., Polskie prawo wyznaniowe, t. I: Zagadnienia wstępne. Rys historyczny, Lublin 1996.

Mniejszości wyznaniowe w Polsce. Prawo wewnętrzne (statutowe), wprowadzenie, zbiór statutów, opracowanie R. Brożyniak, M. Winiarczyk-Kossakowska, Warszawa 20I4.

Mojak R., Kościót a sprawy publiczne w demokratycznym państwie. Podstawy doktrynalne oraz zasady prawne wspótdziatania Kościoła i państwa w sferze życia publicznego, [w:] Funkcje publiczne związków wyznaniowych. Materiaty III Ogólnopolskiego Sympozjum Prawa Wyznaniowego (Kazimierz Dolny, I6-I8 maja 2006), red. A. Mezglewski, Lublin 2007, s. 59-96.

Moore S. F., Law and Anthropology, „Biennial Review of Anthropology” 6 (1969), s. 252-300.

Morawski L., Co może dać nauce prawa postmodernizm?, Toruń $200 \mathrm{I}$. 


\section{Bibliografia}

Morawski L., Gtówne problemy wspótczesnej filozofii prawa. Prawo w toku przemian, Warszawa 1999.

Morawski L., Wstęp do prawoznawstwa, Toruń 2009.

Morawski L., Zasady wyktadni prawa, Toruń 2010.

Mossakowski W., Ugruntowanie autokefalii prawostawia w Polsce wspótczesnej, „Studia Iuridica Toruniensia” II (2012), s. II3-I28.

Murray J. C., Religious freedom, [w:] Documents of Vatican II, in a New and Definitive Translation, with Commentaries and Notes by Catholic, Protestant, and Orthodox Authorities, gen. ed. W. M. Abbott, New York I966, s. 672-674.

Napiórkowski A. A., Teologia jedności chrześcijan. Podręcznik ekumenizmu, Kraków 20II.

New Commentary on the Code of Canon Law, ed. J. P. Beal, J. A. Coriden, T. J. Green, New York-Mahwah 2000.

Niemczyk W., Teologia ksiag wyznaniowych, [w:] Ksieggi wyznaniowe Kościota luterańskiego, Bielsko-Biała 20II, s. 19-28.

Nikołajew J., Wolność sumienia i religii nieletnich przestępców w zaktadach poprawczych $i$ schroniskach dla nieletnich, „Studia z Prawa Wyznaniowego” I5 (2012), s. I57-I84.

Nowacki J., O przepisach zawierajacych klauzule generalne, [w:] Studia z teorii prawa, Zakamycze 2003, s. 133-162.

Nowacki L., Niektóre zagadnienia zasad wspótżycia spotecznego, „Państwo i Prawo" (I957) z. 7-8, s. 99-II3.

Nowak L., Interpretacja prawnicza. Studium z metodologii prawoznawstwa, Warszawa 1973.

Nowicki M., Joke religions jako nowy model religijności wspótczesnej, „Ex Nihilo” 6 (20II) nr 2, s. 57-90.

Ochoa X., Index verborum ac locutionum Codicis Iuris Canonici, Roma I983.

Olszówka M., Przenikanie się prawa państwowego i prawa wewnętrznego zwiąków religijnych z świetle art. 25 ust. 3 konstytucji RP, [w:] Prawo państwowe a prawo wewnętrzne związków wyznaniowych. Pamiętnik VII Zjazdu Katedr i Wyktadowców Prawa Wyznaniowego, Gniezno II-I2 września 20Io, red. K. Krasowski i inni, Poznań 20Io, s. III-I2I.

Olszówka M., Zawieranie umów i uchwalanie ustaw, o których mowa w art. 25 ust. s Konstytucji RP, „Przegląd Sejmowy” (2010) nr 6, s. 49-67.

Opałek K., Interdyscyplinarne zwiazki prawoznawstwa, „Studia Filozoficzne” 2-3 (1985), s. 17-30. 


\section{Bibliografia}

Opałek K., Wróblewski J., Prawo. Metodologia, filozofia, teoria prawa, Warszawa I991.

Opałek K., Zagadnienia teorii prawa i teorii polityki, Warszawa 1986.

Örsy L., Coreccos Theology of Canon Law: A Critical Appraisal, „The Jurist” 53 (1993), s. I86-198.

Örsy L., Interpretation: Guiding Principles, [w:] L. Örsy, Theology and Canon Law. New Horizons for Legislation and Interpretation, Collegeville 1992, s. 53-82.

Örsy L., Relation between Values and Laws, „The Jurist” 47 (1987), s. 477-478. Örsy L., The Interpretation of Laws: New Variations on an Old Theme, [w:] The Art of Interpretation. Selected Studies on the Interpretation of Canon Law, Washington 1982, s. 47-82.

Pasek Z., Wyznania wiary protestantyzmu. Tom zawiera także wyznania wspólnot religijnych XIX i XX wieku wywodzacych się z dziedzictwa reformacji. Wybór tekstów źródtowych, Kraków 1995.

Pawełczyk M., Uwagi o odsytajacym charakterze klauzul generalnych, „Studia Iuridica Silesiana" 9 (1984), s. 8I-99.

Pawluk T., Prawo Kanoniczne wedtug Kodeksu Jana Pawta II, t. I: Zagadnienia wstępne i normy ogólne, Olsztyn 1985.

Pawluk T., Prawo kanoniczne wedtug Kodeksu Jana Pawta II, t. 3: Prawo matżeńskie, Olsztyn 1996.

Pawluk T., Problem wygaśnięcia konkordatu polskiego z 1925 r., „Prawo Kanoniczne" 29 (1986) nr I-2, s. I33-I48.

Pełczyński G., Najmniejsza mniejszośc. Rzecz o Karaimach polskich, Warszawa 1995.

Piaskowy A., Klauzule generalne w projekcie nowego kodeksu cywilnego, „Transformacje Prawa Prywatnego" 3 (2012), s. 49-67.

Piechowiak M., Dobro wspólne jako fundament polskiego porządku konstytucyjnego, Warszawa 2012.

Pietrzak M., Prawo wewnętrzne (kanoniczne) Kościotów i związków wyznaniowych w polskim systemie prawnym, [w:] Prawo państwowe a prawo wewnętrzne zwiazków wyznaniowych. Pamiętnik vii Zjazdu Katedr $i$ Wyktadowców Prawa Wyznaniowego, Gniezno II-I2 września 20I0, red. K. Krasowski i inni, Poznań 20IO, s. 137-150.

Pietrzak M., Demokratyczne świeckie państwo prawne, Warszawa 1999.

Pietrzak M., Model stosunków Państwo-Kościót w świetle ustaw wyznaniowych z I7 maja I989 roku, „Kościół i Prawo” I2 (1994), s. 9-24.

Pietrzak M., Prawo kanoniczne a państwowy porzadek prawny, „Ruch Prawniczy, Ekonomiczny i Socjologiczny" 47 (1985) z. 2, s. I-2I. 


\section{Bibliografia}

Pietrzak M., Prawo kanoniczne w polskim systemie prawnym, „Państwo i Prawo” (2006) z. 8, s. I6-3I.

Pietrzak M., Prawo wyznaniowe, Warszawa 2005.

Piszko R., Odestania, klauzule generalne, luzy decyzyjne, „Ruch Prawniczy, Ekonomiczny i Socjologiczny” 63 (200I) z. I-2, s. 22I-232.

Plisiecki M., Osoba prawna w prawie wewnętrznym kościotów o regulacji ustawowej, Warszawa 2013.

Pospisil L., Anthropology of Law: a Comparative Theory, New York 1971.

Prawo wyznaniowe, red. H. Misztal, P. Stanisz, Lublin 2003.

Radwański Z., Prawo cywilne - część ogólna, Warszawa 2003.

Radwański Z., Zieliński M., Uwagi „de lege ferenda” o klauzulach generalnych w prawie prywatnym, „Przegląd Legislacyjny” (200I) nr 2, s. II-I6.

Radziwonowicz T., Staroobrzędowcy w regionie augustowsko-sejneńsko-suwalskim a wtadze w czasach PRL-u, [w:] Rosjanie na pótnocno-wschodnim Mazowszu w XIX wieku i pierwszej potowie XX wieku. Studia i materiaty, red. M. Gnatowski, Łomża 2009, s. II9-24I.

Rakoczy B., Glosa do wyroku NSA z dnia 8 stycznia 2008, II GSK 286/07, „Orzecznictwo Sądów Polskich” (2009) z. 2, poz. I8.

Rakoczy B., Prawo kanoniczne w orzecznictwie sądów polskich, [w:] Prawo wyznaniowe w Polsce (1989-2009). Analizy, dyskusje, postulaty, red. D. Walencik, Katowice-Bielsko-Biała 2009, s. 275-283.

Raz J., The Authority of Law. Essays on Law and Morality, Oxford 1979.

Redelbach A., Wronkowska A., Ziembiński Z., Zarys teorii państwa i prawa, Warszawa I992.

Rodopoulos P., An Overviwe of Ortodox Canon Law, transl. W. J. Lillie, ed. G. D. Dragas, Rollinsford 2007.

Rott-Pietrzyk E., Klauzula generalna rozsadku w prawie prywatnym, Warszawa 2007.

Rufino, Summa decretorum, ed. H. Singer, Paderborn 1902.

Rybak S., Mariawityzm. Dzieje i wspótczesność, Warszawa 201.

Rzepecki A., Problematyka wygaśnięcia Konkordatu zawartego między Rzeczpospolita Polska a Stolica Apostolska w dniu Io lutego I925 r., „Studia Erasmiana Wratislaviensia” (20II) z. 5, s. 285-304.

Rzepecki A., Funkcjonowanie prawa kanonicznego w polskim porzadku prawnym - zarys tematu, „Acta Erasmiana” 5 (2013), s. I63-184.

Safjan M., Klauzule generalne w prawie cywilnym (przyczynek do dyskusji), „Państwo i Prawo" (I990) z. II, s. 48-59. 
Safjan M., Uniwersalizacja wyktadni prawa, [w:] W poszukiwaniu dobra wspólnego. Ksiega jubileuszowa Profesora Macieja Zielińnkiego, red. A. Choduń, S. Czepita, Szczecin 20IO, s. 27I-298.

Schacht J., An Introduction to Islamic Law, Oxford 1983.

Schwierskott-Matheson E., Wolność sumienia i wyznania w wybranych państwach demokratycznych na przyktadzie regulacji Konstytucji Stanów Zjednoczonych Ameryki, Ustawy zasadniczej Republiki Federalnej Niemiec i Europejskiej konwencji praw cztowieka, orzecznictwa sądów tych krajów oraz Europejskiego Trybunatu Praw Cztowieka, Regensburg 2012.

Seneca ad Lucilium Epistulae Morales: with an English translation by Richard M. Gummere, transl. R. M. Gummere, London-New York 1925.

Simpson S., Joke Religions: Make Believe in the Sandbox of the Gods, „Ex Nihilo” 6 (2OII) nr 2, s. 9I-II8.

Skrzydło W., Konstytucja Rzeczypospolitej Polskiej. Komentarz, Kraków 2002.

Śliwka M., Znaczenie zwrotów niedookreślonych na tle orzecznictwa polskiego Trybunatu Konstytucyjnego, „Studia Iuridica Lubliniensia” I3 (2010), s. 26I-272.

Sobański R., Autonomiczność i niezależność Kościota i pañstwa, „Przegląd Powszechny" 9 (1994), s. I77-I88.

Sobański R., Kościót-prawo-zbawienie, Katowice 1979.

Sobański R., Kościót jako podmiot prawa, Warszawa 1983.

Sobański R., Nauki podstawowe prawa kanonicznego, t. I: Teoria prawa kanonicznego, Warszawa 200I.

Sobański R., Niezależność i autonomia Kościota i państwa podstawowa przestanka. konkordatu, „Ateneum Kapłańskie” 127 (1996) z. I, s. I6-27.

Sobański R., Prawo i moralność, „Śląskie Studia Historyczno-Teologiczne” 32 (I999), s. I6I-I72.

Sobański R., Prawo jako wartość, „Prawo Kanoniczne” 42 (I999) nr 3-4, s. II-26. Sobański R., Prawo kanoniczne a krajowy porzadek prawny, „Państwo i Prawo” (I999) z. 6, s. 3-I7.

Sobański R., Prawo kanoniczne a kultura prawna, „Prawo Kanoniczne” 35 (1992) nr I-2, s. I5-33.

Sobański R., Prawo kościelne na tle trendów antyjurydycznych, „Collectanea Theologica" 43 (1973) fascicle IV, s. 37-46.

Sobański R., Teoria prawa kościelnego, Warszawa 1992.

Sobański R., Ustawa kościelna - ,ordinatio rationis” czy "ordinatio fidei”?, „Collectanea Theologica" 48 (I978) fascicle I, s. 27-35. 
Sobański R., Uwagi o miejscu prawa kanonicznego w kulturze prawnej, [w:] W kierunku religijności, red. B. Bejze, Warszawa 1983, s. 268-282.

Sobczyk P., Konstytucyjna zasada konsensualnego określenia stosunków między Rzeczapospolita Polskq a Kościotem katolickim, Warszawa 2013.

Sobczyk P., Kościót a wspólnoty polityczne, Warszawa 2005.

Sobczak J., Potożenie prawne polskich wyznawców islamu, [w:] Islam a świat, red. R. Bräcker, S. Kitab, Toruń 2003, s. 72-209.

Sobczyk P., Negocjacje i zawarcie umowy $z$ art. 25 ust. 5 Konstytucji RP, [w:] Uktadowe formy regulacji stosunków między państwem a zwiazkami wyznaniowymi (art. 25 ust. 4-5 Konstytucji RP), red. P. Stanisz, M. Ordon, Lublin 2013, s. 277-288.

Sohm R., Kirchenrecht, vol. I: Die geschichtlichen Grundlagen, Leipzig 1923.

Sondel J., Stownik tacińsko-polski dla prawników i historyków, Kraków 1997.

Stahl M., Zasady postępowania przez sadami administracyjnymi, [w:] Państwo w stużbie obywateli. Księga Jubileuszowa Jerzego Światkiewicza, red. R. Hauser, L. Nawacki, Warszawa 2005, s. 216-230.

Stefaniuk M. E., Preambuta aktu normatywnego $w$ doktrynie oraz $w$ procesie stanowienia $i$ stosowania polskiego prawa w latach 1989-2007, Lublin 2009.

Stelmachowski A., Klauzule generalne w kodeksie cywilnym (Zasady wspótżycia spotecznego - spoteczno-gospodarcze przeznaczenie prawa), „Państwo i Prawo” (1965) z. I, s. 5-20.

Stone S. L., In Pursuit of the Counter-Text: the Turn to the Jewish Legal Model in Contemporaty Americal Legal Thought, „Harwdard Law Review” I06 (I993) No. 4, s. 813-894.

Sytuacja prawna Św. Autokefalicznego Kościota Prawostawnego w Polsce, Warszawa I93I.

Szczech T., Rejestracja kościotów i związów wyznaniowych - przywilej czy instrument kontroli?, [w:] Prawo państwowe a prawo wewnętrzne zwiazków wyznaniowych. Pamiętnik VII Zjazdu Katedr i Wyktadowców Prawa Wyznaniowego, Gniezno II-I2 września 20Io, red. K. Krasowski i inni, Poznań 2010, s. 223-229.

Szpunar M., Wyktadnia klauzul generalnych zamieszczonych $w$ dyrektywach wspólnotowych, [w:] Studia z wyktadni prawa, red. C. Martysz, Z. Tobor, Bydgoszcz 2008, s. II2-I22.

Szyszman S., Karaimizm. Historia i doktryna, Wrocław 2005.

Stownik grecko-polski, red. A. Abramowiczówna, t. I, Warszawa 1958.

The Encyclopedia of Religion, ed. M. Eliade, vol. 5, New York-London 1987. 
The Encylopaedia of Islam, ed. P. J. Bearman and others, vol. Io, Leiden 2000. Tokarczuk R., Wspótczesne kultury prawne, Warszawa 2012.

Tomkiewicz M., Ograniczenia alienacji nieruchomości Kościota katolickiego i muzutmańskich wspólnot religijnych - zakres recepcji w prawie polskim, [w:] In persona Christi. Wstużbie pasterskiej obecności Chrystusa. Księga Jubileuszowa dedykowana Księdzu Profesorowi Antoniemu Misiaszkowi w 75. rocznice urodzin, red. E. Wiszowaty, Olsztyn 2013, s. 439-455.

Tomkiewicz M., Stużebność przesytu na gruntach podmiotów konfesyjnych w Polsce. Zagadnienia wybrane, „Przegląd Sądowy” (20I4) nr 7-8, s. 5I-63.

Tomkiewicz M., Zasada równouprawnienia kościotów i związków wyznaniowych a zakres ich autonomii w zarzadzaniu majątkiem na ,forum externum" $w$ Polsce, "Przegląd Religioznawczy” (2013) nr 4, s. 215-227.

Tunia A., Recepcja prawa wewnętrznego związków wyznaniowych w prawie polskim, Lublin 2015.

Uruszczak W., Art. 25 ust. 5 Konstytucji Rzeczypospolitej Polskiej. Problemy interpretacyjne, [w:] Pro bono Reipublicae. Księga jubileuszowa Profesora Michata Pietrzaka, red. P. Borecki, A. Czohara, T. J. Zieliński, Warszawa 2009, s. 477-486.

Uruszczak W., Historia państwa i prawa polskiego, t. I: 966-I795, Warszawa 2010.

Uruszczak W., Recepcja prawa kanonicznego w obowiazującym prawie polskim, „Annales Canonici” 3 (2007), s. 5-2I.

Vorgrimler H., Nowy leksykon teologiczny, przeł. i oprac. T. Mieszkowski, P. Pachciarek, Warszawa 2005.

Walczuk K., Zasada autonomii i wzajemnej niezależności państwa i kościotów oraz innych związków wyznaniowych, [w:] Zasady ustroju politycznego państwa, red. M. Bożek, M. Karpiuk, J. Kostrubiec, K. Walczuk, Poznań 20I2, s. I37-I46.

Walencik A. D., Zakres przedmiotowy art. 25 ust. 5 Konstytucji rp, [w:] Uktadowe formy regulacji stosunków między państwem a związkami wyznaniowymi (art. 25 ust. 4-5 Konstytucji rp), red. P. Stanisz, M. Ordon, Lublin 2013, s. 263-276.

Wallkamm A., Generalklauseln - Normen im Spannungsfeld von Flexibilität und Rechtsstaatswidrigkeit. Über das Verhältnis von Recht und Politik, „Rechtstheorie" 39 (2008) Nr. 4, s. 507-519.

Ware K., Kościót prawostawny, Warszawa 2002.

Washofsky M., Halakhah and Political Theory: A Study in Jewish Legal Response to Modernity, „Modern Judaism” 9 (Oct., I989) No. 3, s. 289-310. 
Wiązek P., Samorzadnośc Muzutmanów w Polsce w świetle przepisów ustawy z dnia 2 I kwietnia I936 roku o stosunku państwa do Muzutmańskiego Związku Religijnego w Rzeczypospolitej Polskiej, [w:] Samorzad i samorzadność w przesztości i teraźniejszości, red. M. J. Ptak, Wrocław 2013, s. I45-156.

Wijlens M., Salus animarum suprema lex: Mercy as a Legal Principle in the Application of Canon Law, „The Jurist” 54 (1994), s. 560-590.

Winczorek P., Komentarz do Konstytucji Rzeczypospolitej Polskiej z 02.04.1997 r., Warszawa 2000.

Witkowski S. W., Wprowadzenie do prawa muzutmańskiego. Wybrane instytucje, Warszawa 2009.

Winiarczyk-Kossakowska M., Ustawy III Rzeczypospolitej o stosunku państwa do Kościotów chrzésijańskich, Warszawa 2004.

Wojciechowski J. M. R., Pisma wybrane - dzieło Bożego ratunku: mariawicki znak czasu, Felicjanów 2003.

Wójcik K., Klauzule generalne jako odestania pozasystemowe, „Acta Universitatis Lodziensis Folia Iuridica" (I987) nr 32, s. I23-I44.

Wójcik K., Klauzule generalne jako zwroty wieloznaczne i oceny, „Studia Prawno-Ekonomiczne" 4I (I988), s. 39-6I.

Wójcik K., Teoretyczna konstrukcja klauzul generalnej, „Studia Prawno-Ekonomiczne" 49 (1990), s. 42-68.

Wronkowska S., Podstawowe pojęcia prawa i prawoznawstwa, Poznań 2005.

Wronkowska S., The Rational Legislator as a Model for the Real Lawmaker, [w:] Polish Contribution to the Theory and Philosophy of Law, ed. Z. Ziembiński, Amsterdam 1987, s. I47-I63.

Wronkowska S., Zieliński M., Komentarz do zasad techniki prawodawczej, Warszawa 2004.

Wronkowska S., Ziembiński Z., Zarys teorii prawa, Poznań 1997.

Wysoczański W., Pietrzak M., Prawo Kościotów i związów wyznaniowych nierzymskokatolickich $w$ Polsce, Warszawa 1997.

Wysoczański W., Polskokatolicyzm. Geneza, dzieje, potożenie prawne, [w:] U. Küry, Starokatolicyzm. Historia, nauka, dązenia, tłum. i oprac. pod kier. W. Wysoczańskiego, Warszawa 1996, s. 425-459.

Zajączkowski A., Zarys religii karaimskiej, Warszawa 2003.

Zarzecki Z., Rola Kościota i związków w wyznaniowych $w$ realizacji wybranych zadań z ustawy o pomocy spotecznej z dnia I2 marca 2004 r., "Studia z Prawa Wyznaniowego" 8 (2005), s. 73-102.

Zieliński M., Wyktadnia prawa. Zasady. Reguty. Wskazówki, Warszawa 2002. 


\section{Bibliografia}

Zieliński M., Ziembiński Z., Uzasadnianie twierdzeń, ocen i norm w prawoznawstwie, Warszawa 1988.

Zieliński T., Klauzule generalne w prawie pracy, Warszawa 1988.

Zieliński T., Mankamenty uktadowego regulowania sytuacji prawnej związków wyznaniowych, „Przegląd Prawa Wyznaniowego” I (2009), s. 27-43.

Zieliński T. J., Niekompetencja religijna wtadz publicznych jako aspekt zasady bezstronności z art. 25 ust. 2 Konstytucji RP, [w:] Bezstronność religijna, światopogladowa i filozoficzna wtadz Rzeczypospolitej Polskiej, red. T. J. Zieliński, Warszawa 2009, s. I4I-I67.

Zieliński T. J., Pojęcie religii, wyznania, związku wyznaniowego i kościota w Konstytucji Rzeczypospolitej Polskiej, „Prawo i Religia” I (2007), s. 29-53.

Zieliński T. J., Prawo wewnętrzne gmin wyznaniowych żydowskich $w$ Polsce a normy ustawowe, „Studia z Prawa Wyznaniowego” I4 (20II), s. 25-45.

Zieliński T. J., Roger Williams. Twórca nowoczesnych stosunków państwo-kościót, Warszawa 1997.

Zieliński T. J., Rozciagnięcie prawa procedowania wyznaniowej formy zawarcia matżeństwa cywilnego na wspólnoty religijne wpisane do rejestru (propozycja „de lege ferenda”), „Przegląd Prawa Wyznaniowego” 4 (20I2), s. I69-176.

Zieliński T. J., Stosowanie wyznaniowej formy zawarcia matżeństwa cywilnego poza Kościotem katolickim, „Państwo i Prawo” (20II) z. 2, s. 19-33.

Zieliński T. J., Ustawa o gwarancjach wolności sumienia i wyznania z I989 r. jako "magna charta" swobód swiatopogladowych $w$ Polsce, [w:] Prawo wyznaniowe w Polsce (1989-2009). Analizy, dyskusje, postulaty, red. D. Walencik, Katowice-Bielsko-Biała 2009, s. 53-65.

Zieliński T. J., W sprawie klasyfikacji wyznań religijnych w Polsce, „Wiadomości Statystyczne" (1995) nr 4, s. 46-49.

Ziembiński Z., Logika praktyczna, Warszawa 200I.

Ziembiński Z., Problemy podstawowe prawoznawstwa, Warszawa 1980.

Ziembiński Z., Stan dyskusji nad problematyka klauzul generalnych, „Państwo i Prawo" (1989) z. 3, s. I4-24.

Znosko A., Kanony Kościota Prawostawnego, Hajnówka 2000.

Żurawik A., Klauzula generalna „dobrych obyczajów”- ujęcie teoretyczne, „Ruch Prawniczy, Społeczny i Ekonomiczny” 7I (2009), s. 35-5I. 


\section{Summary}

\section{Internal Law of Religious Organizations in the Perspective of Organs of Public Authorities: General Clauses}

The religious organizations law, that is, the law that governs the Churches and other religious organizations, differs from the Polish law. This dissimilarity is caused by, among others, the origin of the law, the general aim of law. Consequently, the lawgiver from a religious organization refers in process of drafting law to a different system of values than the Polish legislator. The question must result in specific approach to interpretation of religious organizations law. The rules of interpretation recommended by Polish civil jurisprudence governing the interpretation of Polish law are not fully applicable to religious organizations law.

Due to the fact that Polish law sometimes directly or indirectly refers to religious organizations law, that is, to legal texts of the Churches and other religious organizations, it is expedient for the public authorities to have theoretical knowledge and practical skills to deal with the law of the societies in question.

The book, in general, introduces the religious organizations law to civil lawyers in the context of the Polish regulations regarding freedom of conscience, religious liberty, and also the constitutional principles of independence, autonomy and equal rights of the Churches and other religious organizations.

The book's aim is to give useful and practical instructions for the public authorities to interpret and apply religious organizations law. Special attention is paid in the book to the general clauses. The expressions are rather vague terms that refer to a system of values or assessment outside the given legal system. They are used by the legislator to make legal texts more flexible and open to irregular legal situations. As a result of the usage of them, the users of law can have a certain amount of freedom in defining the content of the legal text and in applying the legal norms.

The general clauses from religious organizations law require a special approach in the process of interpretation of law, different from the one found 
in civil law. One must take into consideration the uniqueness of the religious organizations law wherein the clauses originally function. Even in the case when the expressions in question are formulated in a similar or even identical way in both the Polish law and in the religious organizations law, the genuine meaning of such clauses should not be presumed to be identical.

The main method used in the book is the analysis of the endogenic legal texts of the churches and other religious organizations. The general clauses from the religious organizations law are singled out and uncovered from the laws. Next, they are presented and interpreted according to the rules of interpretation that bind in the law of the churches and other religious organizations. Also, comparative method is used - first to collocate the values of the systems of law, and secondly to juxtapose the most frequently used general clauses and their meanings. Finally, synthesis is used to formulate some conclusions and pieces of advice for those who are to deal with the laws of the churches and other religious organizations.

In the optic of the research are the laws of the churches and other religious organizations whose relations with the Republic of Poland are determined by laws. They are as follows:

I) The Catholic Church,

2) The Polish Autocephalous Orthodox Church,

3) The Evangelical Church of the Augsburg Confession in Poland,

4) The Evangelical Reformed Church in Poland,

5) The United Methodist Church in Poland,

6) The Baptist Union of Poland,

7) The Seventh-day Adventist Church in Poland,

8) The Polish Catholic Church in the Republic of Poland,

9) The Jewish Communities which create the Union of Jewish Religious Communities in Poland,

Io) The Catholic Mariavite Church in Poland,

II) The Old Catholic Mariavite Church in Poland,

I2) The Pentecostal Church of Poland,

I3) The Eastern Old Rites Church not having the Hierarchy in Poland,

I4) The Muslim Religious Union of Poland,

I5) The Karaimi Religious Union of Poland.

In addition, the book allows to have dialogical outlook regarding the religious communities as the societies that value law in general and, as a consequence, to use their law as a tool in regulating life of their believers. 


\section{Table of content}

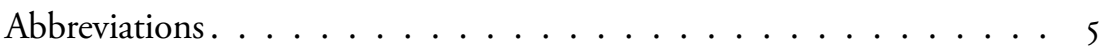

Introduction $\ldots \ldots \ldots \ldots \ldots \ldots \ldots \ldots$

I. Legal status of churches and other religious organizations in the Republic of Poland . . . . . . . . . . . . . . . . Is

I. I. Realization of religious freedom in Polish legal order . . . . . . Is

I.I.I. Freedom of conscience. . . . . . . . . . . . I6

I.I.2. Freedom of religion . . . . . . . . . . . I7

I.I.3. Normative acts and other documents relating

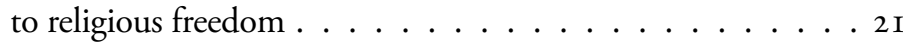

I.I.4. Summary . . . . . . . . . . . . . . . . . . . . . 24

I.2. Subject matter scope of the terms "church"

and "religious organizations" . . . . . . . . . . . . . . 24

I.2.I. Perspective of the state . . . . . . . . . . . 25

I.2.2. Religious perspective. . . . . . . . . . . . . 28

I.2.2.I. Views of the Catholic Church. . . . . . . . . . 28

I.2.2.2. Views of the Reformed Churches . . . . . . . . 3 I

I.3. State - religious organization relations $\ldots \ldots \ldots 32$

I.3.I. Independence and autonomy . . . . . . . . . . . . . 34

I.3.I.I. Perspective of the state $\ldots \ldots \ldots . \ldots 34$

I.3.I.2. Religious perspective . . . . . . . . . . . 37

I.3.I.2.I. Catholic concept . . . . . . . . . 38

I.3.I.2.2. Lutheran concept . . . . . . . . . . 39

I.3.I.2.3. Baptist concept. . . . . . . . . . 442

I.3.I.2.4. Methodist concept . . . . . . . . . . 42

I.3.I.2.5. Mariavite concept . . . . . . . . . 43

I.3.I.2.6. Old Rite Church concept . . . . . . . . 44

I.3.I.2.7. Islamic concept. . . . . . . . . . . 46

I.3.I.2.8. Karaimi concept . . . . . . . . . 48

I.3.I.2.9. Jewish concept . . . . . . . . . . . 49

I.3.I.2.Io. Summary. . . . . . . . . . . . . . 50

I.3.2. Equal rights of the churches and other religious organizations. . . . . . . . . . 5 I

I.3.2.I. Perspective of the state $\ldots \ldots \ldots$. . . . I 
I.3.2.2. Religious perspective . . . . . . . . . . . 53

I.3.3. Cooperation among the state and churches or other religious organizations .................. 54

I.4. Forms of the presence of religious organizations

in Polish legal order . . . . . . . . . . . . . . . . . . 58

I.4.I. Individual law . . . . . . . . . . . . . . . . . . 58

I.4.I.I. Law in force. . . . . . . . . . . . . . . . . . . 58

I.4.I.2. Titles of laws . . . . . . . . . . . . . . . . . . . . . 68

I.4.I.3. Legislative perspective. . . . . . . . . . . . . 69

I.4.2. Registration of the churches and other

religious organizations. . . . . . . . . . . . 73

I.4.3. Lack of administrative registration . . . . . . . . . 76

I.5. Presentation of the churches and other religious organizations,

whose relations with the state are determined by laws,

and of their endogenic law . . . . . . . . . . . . . . . . 77

I.5.I. The Catholic Church. . . . . . . . . . . . . 78

I.5.2. The Polish Autocephalous Orthodox Church . . . . . . 8

I.5.3. The Evangelical Reformed Church in Poland . . . . . . 83

I.5.4. The Evangelical Church of the Augsburg Confession in Poland . . . . . . . . . . . . . . . . . . 84

I.5.5. The United Methodist Church in Poland . . . . . . . . 86

I.5.6. The Old Catholic Mariavite Church in Poland . . . . . . 88

I.5.7. The Catholic Mariavite Church in Poland . . . . . . . 89

I.5.8. The Eastern Old Rites Church not having the Hierarchy in Poland. . . . . . . . . . . . . . . . 90

I.5.9. The Muslim Religious Union of Poland . . . . . . . . . 92

I.5. Io. The Karaimi Religious Union of Poland . . . . . . . . . 96

I.5.I I. The Polish Catholic Church in the Republic of Poland . . 97

I.5.I 2. The Seventh-day Adventist Church in Poland . . . . . . . 98

I.5.13. The Baptist Union of Poland . . . . . . . . . . . . Ioo

I.5.I4. The Jewish Communities which create the Union of Jewish

Religious Communities in Poland . . . . . . . . . . IO I

I.5.I 5. The Pentecostal Church of Poland . . . . . . . . IO2

2. Endogenic law of the churches and other religious organizations. ............... I05 
2.I. Relation of the churches and other religious organizations to their endogenic law. . . . . . . . . . . . . . I05

2.I.I. The concept of unfamiliarity of law . . . . . . . . IOS

2.I.2. The concept of partial acceptance of law . . . . . . I06

2.I.3. The concept of full acceptance of law . . . . . . . . . I08

2.I.4. The concept of radical association with law . . . . . . . I I I

2.I.5. Summary . . . . . . . . . . . . . II

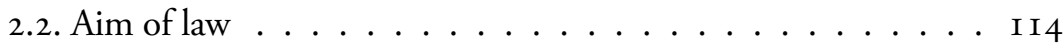

2.2. I. Religious aim . . . . . . . . . . . . II4

2.2.2. Sociological aim . . . . . . . . . . . I I5

2.3. Scope of law. . . . . . . . . . . . . . . II6

2.3.I. System of law . . . . . . . . . . . . . II6

2.3.2. Reference to state law . . . . . . . . . . . I I 8

2.4. Consequences of nonobservance of law . . . . . . . I I 20

2.5. Legal culture as matrix of law . . . . . . . . . . . I22

2.6. Subjects of legislative power. . . . . . . . . . . I I23

2.6.I. The Catholic Church . . . . . . . . . . . . . . I23

2.6.2. The Polish Autocephalous Orthodox Church . . . . . . . I 24

2.6.3. The Evangelical Reformed Church in Poland . . . . . . I25

2.6.4. The Evangelical Church of the Augsburg Confession in Poland. . . . . . . . . . . . . . . I 25

2.6.5. The United Methodist Church in Poland . . . . . . . . I25

2.6.6. The Old Catholic Mariavite Church in Poland . . . . . . I26

2.6.7. The Catholic Mariavite Church in Poland . . . . . . . . . I26

2.6.8. The Eastern Old Rites Church not having the Hierarchy in Poland. . . . . . . . . . . . . . . I26

2.6.9. The Muslim Religious Union of Poland . . . . . . . . . I27

2.6. Io. The Karaimi Religious Union of Poland . . . . . . . . . . I 27

2.6.I I. The Polish Catholic Church in the Republic of Poland . . I 28

2.6.I 2. The Seventh-day Adventist Church in Poland . . . . . . I28

2.6.13. The Baptist Union of Poland . . . . . . . . . . . . I29

2.6.I 4. The Jewish Communities which create the Union of Jewish Religious Communities in Poland . . . . . . . . . I 29

2.6. I 5. The Pentecostal Church of Poland . . . . . . . . . . . I30

2.7. Specific elements of rationality of the religious lawmaker. . . . I30

2.7.I. Personal faith . . . . . . . . . . . I3I

2.7.2. Membership in the society of the faithful . . . . . . I3 I 
2.7.3. Orthodoxy of the doctrine and enacted law . . . . . . . I32

2.7.4. Critical remark . . . . . . . . . . . . I32

2.8. Sources of religious organizations law. . . . . . . . . . I33

2.8. I. Names of normative acts and their publications . . . . . . I 33

2.8.2. Specificity of legislative technique . . . . . . . . . I 40

2.8.3. Language of sources of law. . . . . . . . . . . . I40

2.9. Specific theological-legal character of religious

organizations law . . . . . . . . . . . I4I

2. Io. Interpretation of religious organizations law $\ldots \ldots \ldots$ I 45

2. I I. Religious organizations law - genuine law . . . . . . I I I

2.I 2. Relation of law of the churches and other religious organizations

to Polish law . . . . . . . . . . . . I I 52

2.I2.I. Terminological remarks . . . . . . . . . . I 52

2.I 2.2. Theory of relations . . . . . . . . . . I 53

2.I2.2.I. Theory of extralegal nature of religious

organizations law . . . . . . . . . I54

2.I 2.2.2. Theory of statute nature of religious organizations law . . . . . . . . . . I 54

2.I2.2.3. Theory of full legal effectiveness of religious organizations law . . . . . . . . I55

2.I2.2.4. Theory of limited legal effectiveness of religious organizations law . . . . . . . . I56

2.I2.2.5. Theory of reception of religious organizations law . . . . . . . . . 158

2.I2.3. General rules for relations of religious organizations law to state law in the Republic of Poland . . . . . . . . . . I60

2.I3. Application of religious organizations law in the forum of Polish law. . . . . . . . . . . . . . I6I

2.I3.I. Model approach of the presence of religious organizations law in Polish law . . . . . . . . . . . . . I6I

2.I 3.2. Forms of reference to religious organizations law. . . . . I63 2.I3.2.I. Direct reference . . . . . . . . . . . . I63

2.13.2.2. Indirect reference. . . . . . . . . . . . . I63

2.13.3. Examples of reference to religious organizations law . . . . I64 2.I3.3.I. Concordat . . . . . . . . . . . . . . . I64 2.I3.3.2. Laws about churches and other religious organizations ........... I65 
2.I3.3.2.I. Internal organization. . . . . . . . . I65

2.I3.3.2.2. Competencies of organs . . . . . . I65

2.13.3.2.3. Activity of legal persons . . . . . . . . I65

2.I3.3.2.4. Nomenclature of legal persons . . . . . I 66

2.13.3.3. Other laws . . . . . . . . . . . . . I66

2.13.3.4. Ordinances . . . . . . . . . . . I67

2.I3.3.5. Local legal enactments. . . . . . . . . . . I68

2.13.3.6. Judicial decisions. . . . . . . . . . . . . . . . . . . . . . . . . . . . . . . . . . . . .

2.13.3.7. Contracts . . . . . . . . . . I70

2.I 3.3.8. Supervisory decisions ........... . I7 I

2.I3.3.9. Agreements . . . . . . . . . . . . . I7I

2.I4. Conclusion ................. I72

3. General clauses in endogenic law of the churches and other

religious organizations . . . . . . . . . . . I73

3.I. Definition of general clauses . . . . . . . . . . . I74

3.2. What general clauses are not? . . . . . . . . . . . I77

3.2. I. Indeterminate expressions . . . . . . . . . . . . . . . . . . . . . . . . . . .

3.2.2. Unclear expressions . . . . . . . . . . . . . . I79

3.2.3. Assessment expressions. . . . . . . . . . . . . I80

3.2.4. Evaluative expressions . . . . . . . . . . . I 8 I

3.2.5. References to religious organizations law or state law . . . I 82

3.2.6. References to formalized extralegal systems . . . . . . . I83

3.2.7. Problem of customs in religious communities . . . . . . . I84

3.3. Characteristics of general clauses . . . . . . . . . . . I86

3.3. . Indeterminateness . . . . . . . . . . . . I 86

3.3.2. Extralegal blankness . . . . . . . . . . . . I 87

3.3.3. Reference to axiology . . . . . . . . . . . . I 88

3.4. Functions of general clauses . . . . . . . . . . . I89

3.4. I. Supplementary function . . . . . . . . . . . . . I89

3.4.2. Corrective function . . . . . . . . . . . . . . . . . . . . . . . . . . . . .

3.4.3. Interpretative function . . . . . . . . . . . . I97

3.4.4. The context determines function . . . . . . . . . . . I98

3.5. Margin of decision . . . . . . . . . . . . . . 200

3.6. Effects of functions of general clauses . . . . . . . . . . . 203

3.7. Division of general clauses . . . . . . . . . . . 204

3.8. Searching for the meanings of general clauses . . . . . . . 207 
3.8. I. Sources of axiology. . . . . . . . . . . . . . . . . 207

3.8.r.r. Values in religious law. . . . . . . . . . . 207

3.8.1.2. Changeable character of passing judgment . . . . . 2 I I

3.8.I.3. Introduction to normative acts . . . . . . . . 2 $2 \mathrm{I} 2$

3.8.I.4. Provisions of the body of law . . . . . . . . 213

3.8.2. Searching for the meanings of general clauses . . . . . . $2 \mathrm{I} 4$

3.8.2. I. Administrative decisions . . . . . . . . . 2I 4

3.8.2.2. Court decisions . . . . . . . . . . . 219

3.8.2.3. Authentic interpretation . . . . . . . . . . . 220

3.8.2.4. Interpretations in the form of law. . . . . . . . 220

3.8.2.5. Legal doctrine. . . . . . . . . . . . . . . . 22I

3.8.2.6. Religious interpretation . . . . . . . . . . . . . 223

3.8.2.7. Interpretation referring to sacred texts . . . . . . . . . 223

3.8.3. The limits of meaning of general clauses . . . . . . . . . 224

3.9. Comparison of general clauses in religious organizations law and Polish law. . . . . . . . . . . . . . . 226

3.ro. Practical instructions for the public authorities. . . . . . . 228

3.Io. I. Rules referring to religious organizations law . . . . . . 228

3.10.2. Rules referring to general clauses . . . . . . . . . . 229

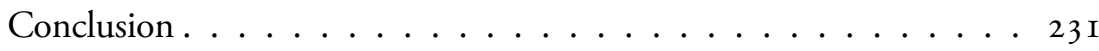

Bibliography . . . . . . . . . . . . . . . 233

I. Normative acts and doctrinal documents of the churches and other religious organizations . . . . . . . . . . . . 233

2. State normative acts and other documents . . . . . . . . 242

3. Judicial decisions . . . . . . . . . . . . . . . . . . . . . . . . . . . . . . . . . . . . . . . . .

4. Secondary sources . . . . . . . . . . . . . 252 


\section{Spis treści}

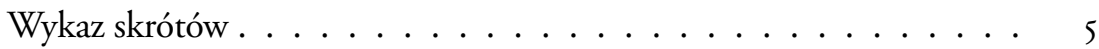

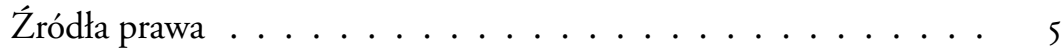

Inne skróty $\ldots \ldots \ldots \ldots \ldots \ldots \ldots$

Wstęp ........................... 9

I. Status prawny kościołów i innych związków wyznaniowych w Rzeczypospolitej Polskiej . . . . . . . . . . . . . . . . . . I 5

I. I. Realizacja wolności religijnej w polskim porządku prawnym . . Is

I.I.I. Wolność sumienia . . . . . . . . . . . . . . . . I6

I.I.2. Wolność wyznania. . . . . . . . . . . . . . . . I7

I.I.3. Akty normatywne i inne dokumenty dotyczące wolności religijnej. . . . . . . . . . 2I

I.I.4. Podsumowanie . . . . . . . . . . . . . . . . 24

I.2. Zakres przedmiotowy terminów „kościół” i „związek wyznaniowy” . . . . . . . . . . . . . . 24

I.2.I. Perspektywa państwowa . . . . . . . . . . . . . . . 25

I.2.2. Perspektywa religijna . . . . . . . . . . . . . 28

I.2.2. I. Poglądy Kościoła katolickiego _ . . . . . . . . 28

I.2.2.2. Poglądy Kościołów Reformacji . . . . . . . . . 3 I

I.3. Relacje państwo - związek wyznaniowy. . . . . . . . . . 32

I.3.r. Niezależność i autonomia . . . . . . . . . . . . . . 34

I.3.I.I. Perspektywa państwowa. . . . . . . . . . . . 34

I.3.I.2. Perspektywa religijna . . . . . . . . . . . 37

I.3.I.2.I. Koncepcja katolicka . . . . . . . . . 38

I.3.I.2.2. Koncepcja luterańska . . . . . . . . 39

I.3.I.2.3. Koncepcja baptystyczna . . . . . . . . . 42

I.3.I.2.4. Koncepcja metodystyczna . . . . . . . 42

I.3.I.2.5. Koncepcja mariawicka . . . . . . . . . . 43

I.3.I.2.6. Koncepcja staroobrzędowa . . . . . . . . . . 44

I.3.1.2.7. Koncepcja islamska. . . . . . . . . . . . 46

I.3.I.2.8. Koncepcja karaimska. . . . . . . . . . . 48

I.3.I.2.9. Koncepcja żydowska . . . . . . . . . . . . . . . . . . . . . . . . .

I.3.I.2.Io. Podsumowanie. . . . . . . . . 50 
I.3.2. Równouprawnienie kościołów

i innych związków wyznaniowych . . . . . . . . . . 5 I

I.3.2. I. Perspektywa państwowa ......... . 5 I

I.3.2.2. Perspektywa religijna . . . . . . . . . . 53

I.3.3. Współpraca państwa z kościołami

oraz innymi związkami wyznaniowymi . . . . . . . . . 54

I.4. Formy obecności związków wyznaniowych

w polskim porządku prawnym . . . . . . . . . . . 58

I.4. I. Indywidualna regulacja ustawowa . . . . . . . . . . . . . . 58

I.4.I.I. Obowiązujące ustawy . . . . . . . . . . . 58

I.4.I.2. Tytuły ustaw . . . . . . . . . . . . . 68

I.4.I.3. Perspektywa ustawodawcza . . . . . . . . . . . 69

I.4.2. Wpis do rejestru kościołów

i innych związków wyznaniowych . . . . . . . . . . 73

I.4.3. Brak rejestracji administracyjnej . . . . . . . . . . 76

I. 5. Prezentacja kościołów i innych związków

wyznaniowych o uregulowanym przez ustawy

stosunku do państwa oraz ich wewnętrznego prawa . . . . . 77

I.5. . Kościół katolicki . . . . . . . . . . . . 78

I.5.2. Polski Autokefaliczny Kościół Prawosławny . . . . . . . . 8 I

I.5.3. Kościół Ewangelicko-Reformowany

w Rzeczypospolitej Polskiej. . . . . . . . . . . . . . . . . 83

I.5.4. Kościół Ewangelicko-Augsburski

w Rzeczypospolitej Polskiej. . . . . . . . . . . . . . . . . 84

I.5.5. Kościół Ewangelicko-Metodystyczny

w Rzeczypospolitej Polskiej. . . . . . . . . . . . . . . . . 86

I.5.6. Kościół Starokatolicki Mariawitów

w Rzeczypospolitej Polskiej. . . . . . . . . . . . . . . . . 88

I.5.7. Kościół Katolicki Mariawitów

w Rzeczypospolitej Polskiej. . . . . . . . . . . . . . . . . 89

I.5.8. Wschodni Kościół Staroobrzędowy nieposiadający

hierarchii duchownej w Rzeczypospolitej Polskiej . . . . 90

I.5.9. Muzułmański Związek Religijny

w Rzeczypospolitej Polskiej. . . . . . . . . . . . . . . . . 92

I.5. Io. Karaimski Związek Religijny

w Rzeczypospolitej Polskiej. . . . . . . . . . . . . . . . . 96 
I.5. I I. Kościół Polskokatolicki w Rzeczypospolitej Polskiej . . . 97

I.5. I 2. Kościół Adwentystów Dnia Siódmego w Rzeczypospolitej Polskiej . . . . . . . . . . . . . . . 98

I.5.I3. Kościół Chrześcijan Baptystów w Rzeczypospolitej Polskiej . . . . . . . . . . . . . I Io०

I.5.I4. Związek Gmin Wyznaniowych Żydowskich w Rzeczypospolitej Polskiej . . . . . . . . . . . . . . IO I

I.5. I 5. Kościół Zielonoświątkowy w Rzeczypospolitej Polskiej . IO2

2. Prawo endogeniczne kościołów

i innych związków wyznaniowych . . . . . . . . . I05

2. I. Stosunek kościołów lub innych związków

wyznaniowych do własnego prawa endogenicznego. . . . . I05

2.r... Koncepcja obcości prawa . . . . . . . . . . . I05

2.r.2. Koncepcja częściowej akceptacji prawa . . . . . . . . . Io6

2.ı.3. Koncepcja pełnej akceptacji prawa . . . . . . . . . Io8

2.I.4. Koncepcja radykalnego związania z prawem. . . . . . . . . I I I

2.I.5. Podsumowanie . . . . . . . . . . . . I I4

2.2. Cel prawa .................... II 4

2.2. I. Cel religijny ................. I I4

2.2.2. Cel socjologiczny . . . . . . . . . . . I I

2.3. Zakres prawa ..................... II6

2.3. . System prawa . . . . . . . . . . . I I6

2.3.2. Odesłania do prawa państwowego. . . . . . . . I I 8

2.4. Konsekwencje nieprzestrzegania prawa . . . . . . . . I 20

2.5. Kultura prawna jako matrix prawa . . . . . . . . . . . . I22

2.6. Podmioty władzy ustawodawczej . . . . . . . . . . . I23

2.6. . Kościół katolicki . . . . . . . . . . . . . . I 23

2.6.2. Polski Autokefaliczny Kościół Prawosławny . . . . . . . . . I 24

2.6.3. Kościół Ewangelicko-Reformowany

w Rzeczypospolitej Polskiej . . . . . . . . . . . . . I 25

2.6.4. Kościół Ewangelicko-Augsburski w Rzeczypospolitej Polskiej . . . . . . . . . . . . I 25

2.6.5. Kościół Ewangelicko-Metodystyczny w Rzeczypospolitej Polskiej . . . . . . . . . . . . . I 25

2.6.6. Kościół Starokatolicki Mariawitów w Rzeczypospolitej Polskiej . . . . . . . . . . . . . I26 
2.6.7. Kościół Katolicki Mariawitów

w Rzeczypospolitej Polskiej . . . . . . . . . . . . . . . . I26

2.6.8. Wschodni Kościół Staroobrzędowy nieposiadający hierarchii duchownej w Rzeczypospolitej Polskiej . . . . . I 26

2.6.9. Muzułmański Związek Religijny w Rzeczypospolitej Polskiej . . . . . . . . . . . . . . . . I 27

2.6. Io. Karaimski Związek Religijny w Rzeczypospolitej Polskiej . . . . . . . . . . . . . . . I 27

2.6. I I. Kościół Polskokatolicki w Rzeczypospolitej Polskiej . . . . I 28

2.6. I 2. Kościół Adwentystów Dnia Siódmego w Rzeczypospolitej Polskiej . . . . . . . . . . . . . I28

2.6.I3. Kościół Chrześcijan Baptystów w Rzeczypospolitej Polskiej . . . . . . . . . . . . . . I 29

2.6. I4. Związek Gmin Wyznaniowych Żydowskich. . . . . . . . I 29

2.6. I 5. Kościół Zielonoświątkowy w Rzeczypospolitej Polskiej . . I 30 2.7. Specyficzne elementy racjonalności prawodawcy religijnego ............... I 30

2.7.I. Osobista wiara . . . . . . . . . . . I3 I

2.7.2. Członkostwo w społeczności wiernych . . . . . . . . . I I I

2.7.3. Ortodoksja doktryny i stanowionego prawa . . . . . . I 32

2.7.4. Uwaga krytyczna . . . . . . . . . . . . . . I 32

2.8. Źródła prawa związków wyznaniowych . . . . . . . . I I33

2.8. I. Nazwy aktów normatywnych i ich publikatory . . . . . . I33

2.8.2. Specyfika techniki legislacyjnej . . . . . . . . . . . I 40

2.8.3. Język aktów normatywnych . . . . . . . . . . . . . I40 2.9. Specyficzny charakter teologiczno-prawny

prawa religijnego ................ I4I

2.ı. Wykładnia prawa związków wyznaniowych . . . . . . . I45

2. I I. Prawo związków wyznaniowych -

prawdziwe prawo . . . . . . . . . . . I 5 I

2.I2. Relacja prawa kościołów lub innych związków wyznaniowych do prawa polskiego . . . . . . . . . . . . I 52

2.I2.I. Uwagi terminologiczne. . . . . . . . . . . I 52

2.I 2.2. Teorie relacji . . . . . . . . . . . . I 53

2.I2.2.I. Teoria pozaprawnej natury prawa związków wyznaniowych . . . . . . . . I54 
2.I 2.2.2. Teoria natury statutowej prawa związków wyznaniowych . . . . . . . . I 54

2.I 2.2.3. Teoria pełnej skuteczności prawnej prawa związków wyznaniowych . . . . . . I 55

2.I 2.2.4. Teoria ograniczonej skuteczności prawnej prawa związków wyznaniowych . . . . . . . I56 2.I 2.2.5. Teoria recepcji prawa związków wyznaniowych. . . . . . . . . I58

2.I 2.3. Ogólne zasady relacji prawa związków wyznaniowych do prawa państwowego w Rzeczypospolitej Polskiej . . . . I60

2.I 3. Stosowanie prawa związków wyznaniowych na forum prawa polskiego . . . . . . . . . . . I6I 2.I3. I. Modelowe ujęcie obecności prawa związków wyznaniowych w prawie polskim . . . . . . . . . I6I

2.1 3.2. Formy odesłania do prawa związków wyznaniowych. . . . I63 2.I3.2. I. Odesłanie bezpośrednie . . . . . . . . . I63

2.I3.2.2. Odesłanie niebezpośrednie . . . . . . . . . I63

2.1 3.3. Przykłady odesłań do prawa związków wyznaniowych . . . I64

2.I3.3.I. Konkordat. . . . . . . . . . . . . . I64

2.I3.3.2. Ustawy wyznaniowe . . . . . . . . . . I65 2.I3.3.2.I. Organizacja wewnętrzna . . . . . . . I65 2.13.3.2.2. Kompetencje organów . . . . . . . I65

2.13.3.2.3. Działalność osób prawnych ..... . I65

2.13.3.2.4. Nazewnictwo osób prawnych . . . . . I66

2.I3.3.3. Inne ustawy . . . . . . . . . . . . . I66

2.I3.3.4. Rozporządzenia . . . . . . . . . . . . I67

2.I3.3.5. Akty prawa miejscowego . . . . . . . . . I68

2.I3.3.6. Orzecznictwo . . . . . . . . . . I 68

2.I3.3.7. Umowy . . . . . . . . . . . . . I70

2.I3.3.8. Rozstrzygnięcia nadzorcze . . . . . . . . I7 I

2.I3.3.9. Porozumienia . . . . . . . . . . I7I

2.I4. Wniosek.................... I72

3. Klauzule generalne w endogenicznym prawie kościołów i innych związków wyznaniowych . . . . . . . . . . . . I73 3. I. Definicja klauzul generalnych. . . . . . . . . . . I74 3.2. Czym nie są klauzule generalne? . . . . . . . . . . . . I I77 
3.2.I. Zwroty niedookreślone . . . . . . . . . . . . I78

3.2.2. Zwroty nieostre . . . . . . . . . . . . . . . . . . . . . . . . . . . . . . . . . . . . . .

3.2.3. Zwroty szacunkowe . . . . . . . . . . . . . . . . . . . . . . . . I8

3.2.4. Zwroty ocenne . . . . . . . . . . . . . I8 I

3.2.5. Odesłania do prawa związków wyznaniowych lub prawa państwowego . . . . . . . . . . I82

3.2.6. Odesłania do sformalizowanych systemów pozaprawnych . . . . . . . . . . . . I83

3.2.7. Problem zwyczajów we wspólnotach religijnych . . . . . I 84 3.3. Cechy klauzul generalnych . . . . . . . . . . . . . . . . . . . 86

3.3.I. Niedookreśloność . . . . . . . . . . . . . . . . . . . . . . 186

3.3.2. Pozaprawne odestanie . . . . . . . . . . . . . . I87

3.3.3. Aksjologiczność . . . . . . . . . . . . . I 188

3.4. Funkcje klauzul generalnych . . . . . . . . . . . . . . . . . . . . . . . . . . . . . .

3.4. I. Funkcja uzupełniająca . . . . . . . . . . . . . . . . . . . . . . . . . I99

3.4.2. Funkcja korygująca . . . . . . . . . . . . . . . . . I93

3.4.3. Funkcja interpretacyjna . . . . . . . . . . . . . . . . . . . 197

3.4.4. Kontekst wyznaczający funkcję . . . . . . . . . . . . . 198

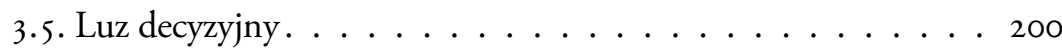

3.6. Skutki funkcji klauzul generalnych . . . . . . . . . . . . . . 203

3.7. Podział klauzul generalnych . . . . . . . . . . . . . 204

3.8. Poszukiwanie desygnatów klauzul generalnych . . . . . . . . . 207

3.8. . Źródła aksjologiczne . . . . . . . . . . . . . . . . 207

3.8. I. I. Wartości w prawie religijnym. . . . . . . . . 207

3.8.I.2. Zmienny charakter wartościowania. . . . . . . . 2 I I

3.8.I.3. Wprowadzenia do aktów normatywnych . . . . . 2 I2

3.8.r.4. Przepisy tekstu głównego . . . . . . . . . . 21 3

3.8.2. Poszukiwanie znaczeń klauzul generalnych . . . . . . . 2 I4

3.8.2. I. Decyzje administracyjne . . . . . . . . . . . 2 I4 . . . 2I9

3.8.2.2. Orzeczenia sądowe . . . . . . . . . . . . . 219

3.8.2.3. Wykładnie autentyczne . . . . . . . . . . . 220

3.8.2.4. Wykładnia w formie ustawy . . . . . . . . . 220

3.8.2.5. Doktryna prawnicza . . . . . . . . . . 22I

3.8.2.6. Wykładnia religijna . . . . . . . . . . . . . 223

3.8.2.7. Wykładnia odnosząca się do świętych tekstów . . . 223

3.8.3. Granice znaczeń klauzul generalnych . . . . . . . . . 224 
3.9. Porównanie klauzul generalnych

prawa związków wyznaniowych i prawa polskiego . . . . . . . 226

3.ro. Wskazówki praktyczne

dla organów władzy publicznej . . . . . . . . . . . 228

3.Io.r. Zasady odnoszące się do prawa

związków wyznaniowych . . . . . . . . . . . 228

3.Io.2. Zasady odnoszące się do klauzul generalnych

w prawie związków wyznaniowych . . . . . . . . . . . 229

Zakończenie ..................... 23I

Bibliografia ....................... 233

I. Akty normatywne i dokumenty doktrynalne

kościołów i innych związków wyznaniowych . . . . . . . . . . 233

2. Państwowe akty normatywne i inne dokumenty . . . . . . . . 242

3. Judykaty . . . . . . . . . . . . . . . . . . . . 249

4. Literatura przedmiotu . . . . . . . . . . 252

Summary. . . . . . . . . . . . . . . . . . . . . . . . 269

Table of content . . . . . . . . . . . . . 27 I 
